
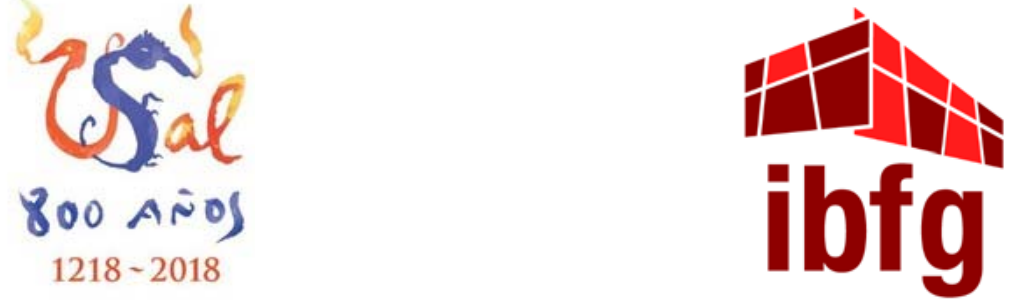

\title{
Metabolic adaptations of neurons to physiological oxygen concentrations
}

- Doctoral Thesis -

Moussa WARDE

Directors:

- Prof. Dr. D. Juan Pedro Bolaños Hernández

- Prof. Dr. D. Emilio Fernández Sánchez

Salamanca, 2018 


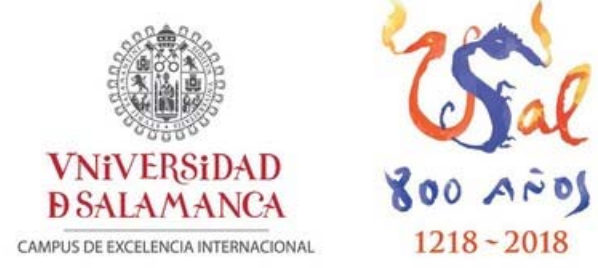

800 Años

1218 - 2018

Juan Pedro Bolaños Hernández, Catedrático de Bioquímica y Biología Molecular de la Universidad de Salamanca, y Emilio Fernández Sánchez, Profesor Titular y Director de departamento de Bioquímica y Biología Molecular de la Universidad de Salamanca,

Autorizan:

La presentacion de la Tesis Doctoral titulada "Metabolic adaptations of neurons to physiological oxygen concentrations", que ha sido realizada bajo su dirección por el Licenciado en Biología y Neurociencias D. Moussa WARDE, en el Instituto de Biología Funcional y Genómica, de la Universidad de Salamanca. En nuestra opinión, reúne todos los requisitos científicos y formales para ser defendida y optar al Título de Doctor Internacional.

Salamanca, a 20 de julio de 2018

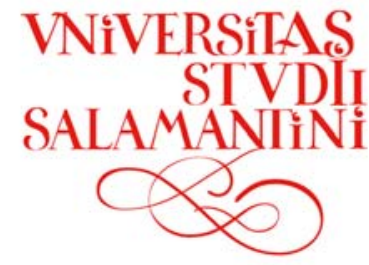

Fdo.: Juan Pedro Bolaños Hernández Fdo.: Emilio Fernández Sánchez 



\section{Acknowledgments/Agradecimientos}

Esta tesis es el trabajo de un grupo y no de una persona, tienen sus méritos muchas personas dedicadas que aparecieron durante y antes del desarrollo de este trabajo. Un cambio de un campo de neurociencia molecular basada en el uso de la electrofisiología y el estudio de las propiedades de las neuronas dopaminérgicas de la substancia negra pars compacta en cultivos órganotipicos, a un campo de biología molecular y funcional investigando el cerebro desde los efectos del oxígeno físiológico sobre las células cerebrales desarrollando técnicas totalmente distintas a las que había aprendido anteriormente.

Desde el inicio, he tenido el sentido de agradecimiento al Pr. Juan Pedro Bolaños que me ha permitido este traspaso y la inserción en su grupo de investigación. Muchas gracias a ti por darme tu confianza y permitir que dispongamos de toda la herramienta necesaria para el desarrollo de esta tesis.

A Emilio, un mérito excepcional en este trabajo y en mi formación personal. Me ha abierto otros horizontes, y me incitó a aprender otros programas profesionales que me han sido de gran ayuda. Siempre ha estado presente para guiar, aconsejar e intervenir cuando algo iba mal. Te agradezco mucho tu dedicación y tu aportación a la tesis, siempre has estado cuando te he necesitado y, sobre todo, los últimos dos años del desarrollo de la tesis, no distinguías día y noche, ni festivos para contestar, corregir y trabajar para que siga adelante. Dani, siempre has estado como el ángel de la guarda, tu trabajo no sale mucho a la luz, pero he de reconocer que me enseñaste la mayoría de las técnicas y participaste de cerca en el desarrollo de mi tesis. Siempre he tenido que recurrir a ti en primer lugar para entender los resultados y buscarles explicaciones. Compartir el espacio de trabajo contigo siempre ha sido una alegría. 3 años pasaron sin darme cuenta.

Irene López, siempre has estado muy liada pero aun así no has dudado en ayudar, tus breves explicaciones al principio me empujaron a aprender el castellano. Desde tu reincorporación en el laboratorio, como madre, has estado más atenta a los demás. Gracias

Costanza, durante el año que has estado en el laboratorio, he envidiado tu entusiasmo a servir y ayudar cuando se te ha necesitado. De ti he aprendido muchas cosas que luego me han servido en la tesis. Gracias 
Ana, siempre sonriente, me daba el alivio en los malos momentos, jánimo! Espero verte ser doctora pronto.

Carlos, siempre con muchas preguntas que nos hacen reflexionar. Amable y servicial, gracias por tu presencia y tu participación cuando se te pedía.

Nico, sabe dedicar el tiempo para expresar su conocimiento en farmacia. Gracias por servir como traductor del castellano al francés al principio de mi incorporación en el labo. A pesar de nuestras diferencias, nos hemos ayudado mucho durante el proyecto TINTIN contribuyendo en su éxito.

Brenda, a pesar del calor del verano no dudaste en prestarme ayuda cuando te lo he pedido, gracias.

Mónica Carabias, nunca me olvidaré de tu contribución en mi aprendizaje del castellano, el primer regalo que he recibido en el laboratorio fue de ti, un libro de enseñanza básica del castellano. Me ha servido mucho, ya que, usándolo durante unos meses, he podido formular mis primeras expresiones. Con Estefanía y Lucía habéis formado un gran equipo que hizo que no nos faltarán animales. Gracias a las tres.

Mónica Resch, siempre presente para atender, guiar y ofrecer su conocimiento. Si he podido casi siempre disponer del material necesario para la investigación fue por tu dedicación a encontrar lo necesario en tiempo olímpico. Sin olvidar los protocolos y las explicaciones que siempre ofrecías, en inglés como en castellano. Gracias

Rubén Quintana, sus intervenciones, a distancia o presenciales siempre han sido de gran ayuda. Has participado en la elaboración del proyecto de estancia en Padova, como en el análisis de los resultados y la formulación correcta del informe. Gracias.

Agradezco al laboratorio 2.8 y su directora Ángeles Almeida, por su colaboración en los trabajos de investigación ofreciendo sus conocimientos y experiencia. En particular, a María Delgado, por el tiempo dedicado a enseñarme el uso de la citometría de flujo y el análisis de los resultados. Tu participación ha sido fundamental sin falta. Irene Sire, has sido de las personas secretas que más me apoyaron y ayudaron cuando hizo falta. Si me llevo recuerdos de buenos amigos del laboratorio serás la primera de la lista sin lugar a duda. Verónica, a pesar de nuestro malentendido al principio de mi incorporación en el labo, has ofrecido generosamente tus ayudas y has compartido con todos nosotros tus alegrías y tus dolencias. Eres una persona maravillosa. Sin olvidarme de Rebeca Vecino, Rebeca Lapresa, Jesús, Cristina y los demás. 
Agradezco a Lucas Scorrano y su laboratorio por acogerme en su laboratorio durante 3 meses, y asegurar todo el material necesario para poner a punto los cultivos primarios de neuronas y astrocitos en su laboratorio y disponer de la herramienta necesaria para reconstruir las mismas condiciones y usar su modelo animal y su experiencia en el dominio de la mitocondria para sacar unos resultados magníficos y complementar mi tesis.

Agradezco al apoyo del personal de IBFG, Carmen Castro y su gran aportación en el trabajo de microscopia, Javier Borroso y Paco por la asistencia técnica, Alberto, Noelia, Mari Carmen y los demás.

A mi familia, mis hermanos y especialmente mi hermana Micheline y su intervención científica y sus consejos desde París cada vez que la he pedido. A mí madre, que ha sufrido de todo para cuidar de mí, y abrirme puertas para avanzar en la vida. Sé que siempre me está esperando, y los años empiezan a pesar, pero espero no defraudarle y poder volver un día a estar más tiempo con ella y agradecerle todos sus sacrificios.

A mis amigos y cercanos, Mónica, Chris, Urbano, Rubén (labo 2.6), Hanna, Raymond, Elie, RP. Juanjo (Salamanca), RP. Pablo (Salamanca), RP. Luis (Marsella), RP. Michel Marie Zanotti (Marsella), RP. Joseph Hallit (Líbano) y muchos más que no cabe sitio para citarlos. A Don Tomás Santamaría Polo, vicerrector de Investigación de la Universidad Católica de Ávila por su apoyo permitiendo la estancia necesaria para finalizar la Tesis.

Finalmente, agradezco a la Comisión Europea, la asociación MCAA, por la contribución en este manuscrito, los coordinadores y los participantes en el proyecto europeo TINTIN dentro del programa Marie Skłodowska-Curie actions, ITN, por la oportunidad de participar en una formación internacional, diversa, continúa y permitirme formar parte de una red que sin lugar a duda me hará crecer más en el futuro. 



\section{Table of contents}

Table of contents ..................................................................................

List of abbreviations ......................................................................... vi

1- Introduction ....................................................................................................... 1

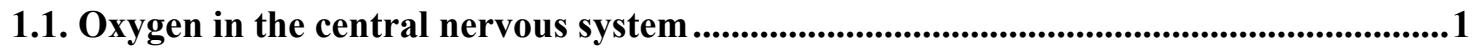

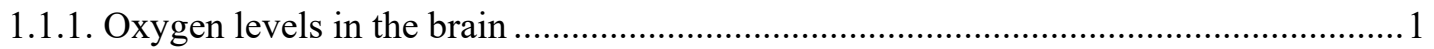

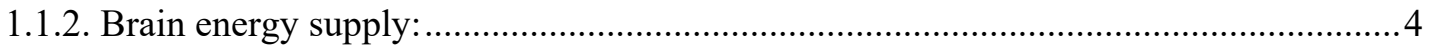

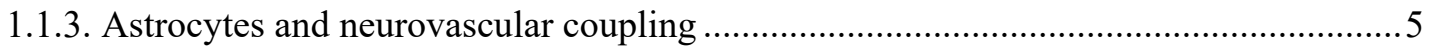

1.1.4. Adaptation of the brain to acute and chronic exposure to hypoxia................................ 6

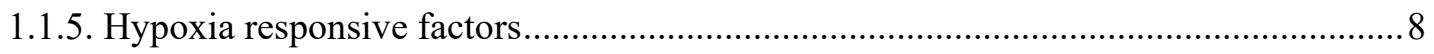

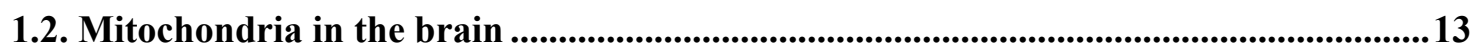

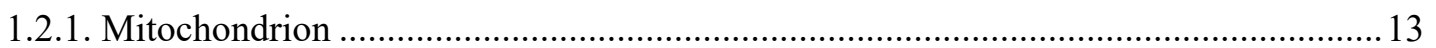

1.2.2. The Mitochondrial Respiratory Chain (MRC)............................................................ 13

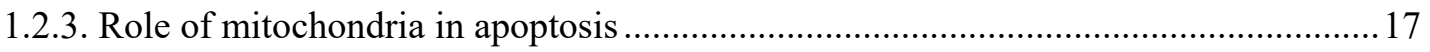

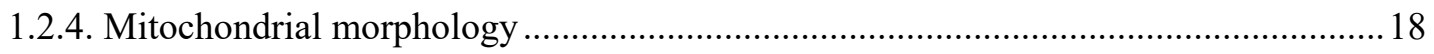

1.3. Brain energy metabolism......................................................................................................20

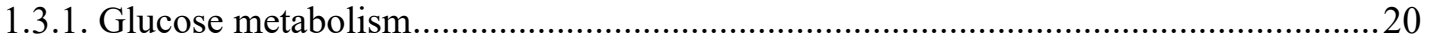

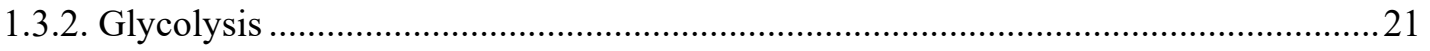

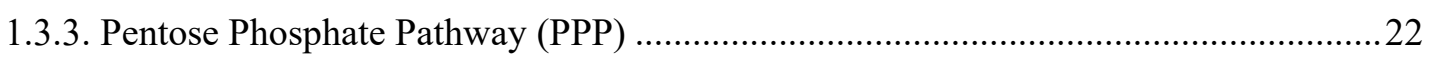

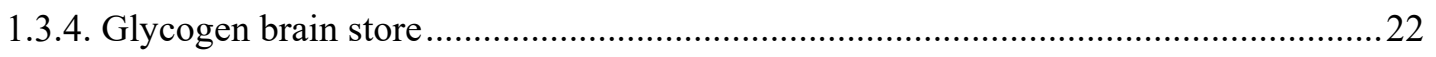

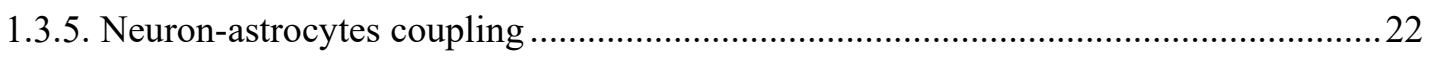

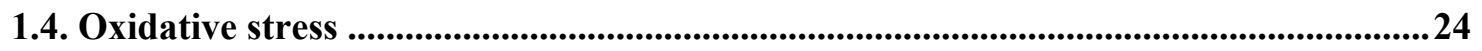

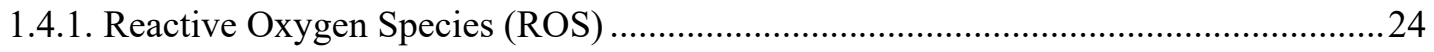

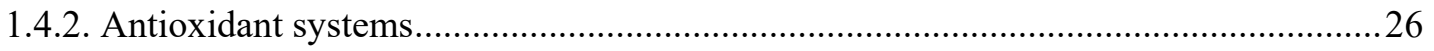

2- Hypothesis and objectives............................................................... 29

3- Material and methods ................................................................30

3.1. Animals ..........................................................................................................................30

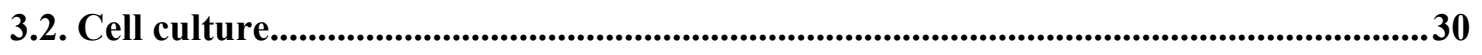

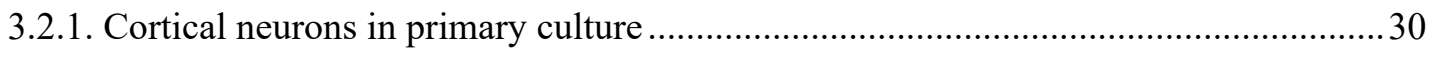

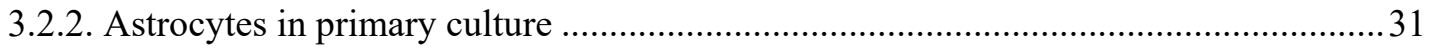




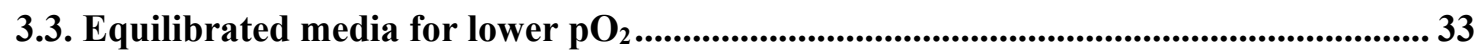

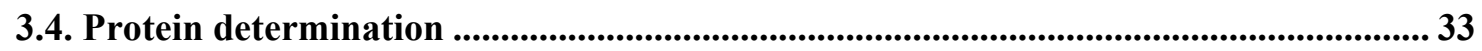

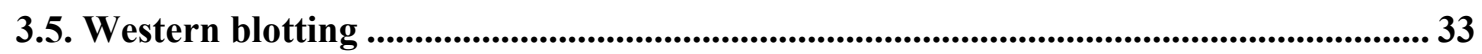

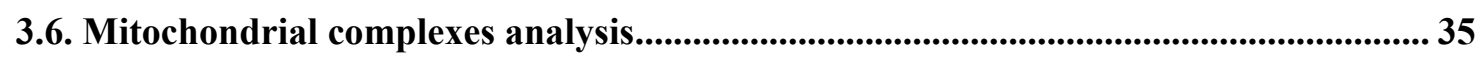

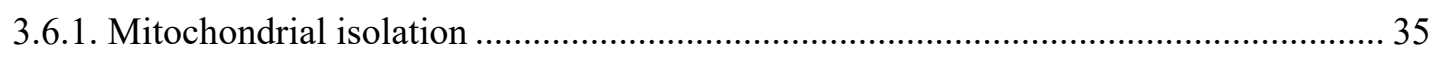

3.6.2. BNGE (Blue Native Gel Electrophoresis) and transfer............................................ 36

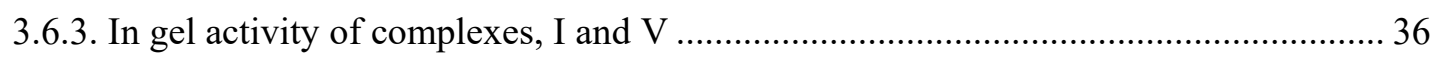

3.7. Mitochondrial membrane potential .......................................................................................... 37

3.8. Determination of reactive oxygen species.............................................................................. 38

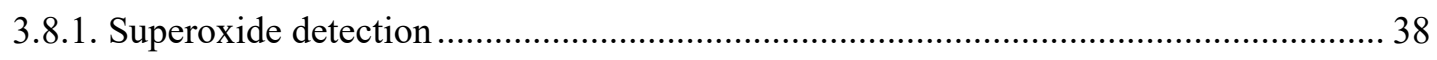

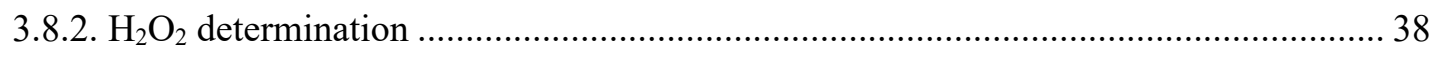

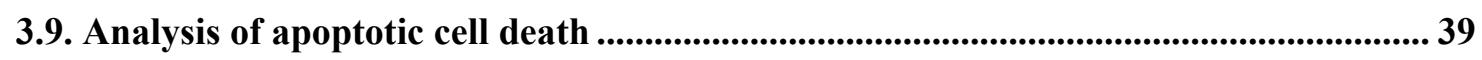

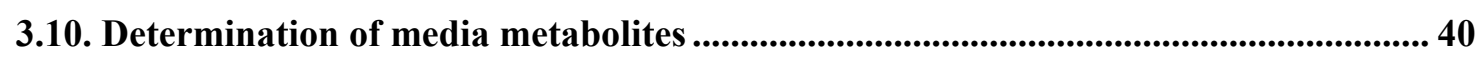

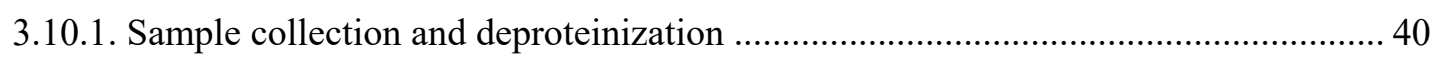

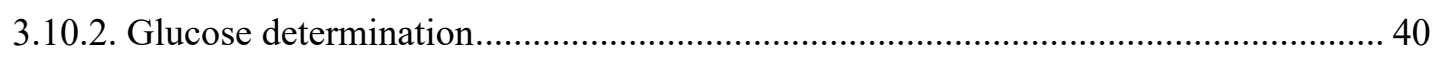

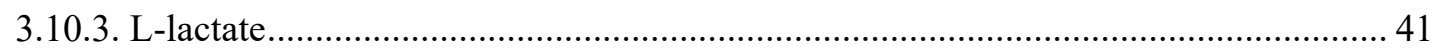

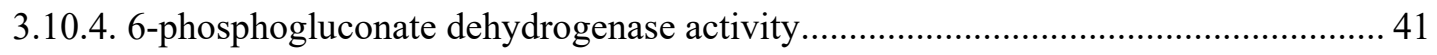

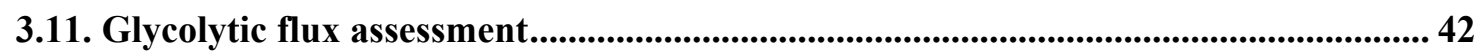

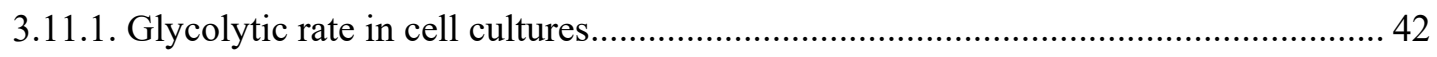

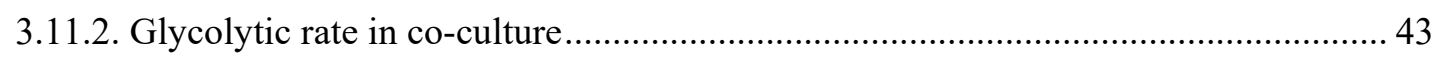

3.12. Determination of incorporated bromodeoxyuridine .................................................. 44

3.13. Real-Time or quantitative Polymerase Chain Reaction (RT-qPCR) and

transcriptomic microarrays.................................................................................................................... 44

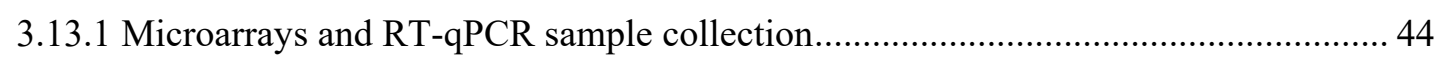

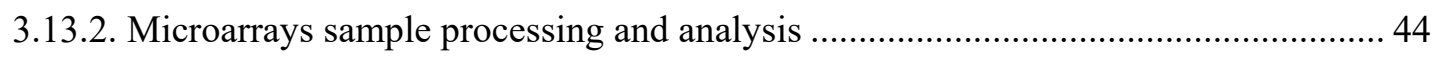

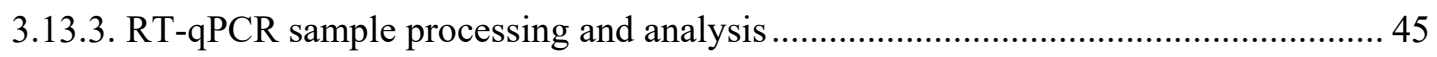

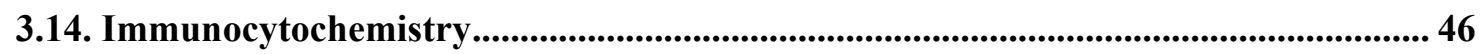

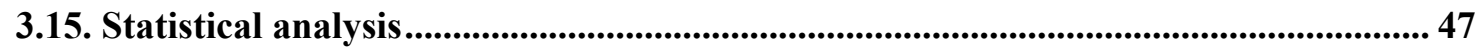

4- Results ..................................................................................................48

4.1. Changes in the survival and oxidative metabolism in neurons and astrocytes at physiological $\mathrm{pO}_{2}$..................................................................................................................48

4.1.1. Pysiological $\mathrm{pO}_{2}$ improves survival in cultured brain cells ...................................... 48

4.1.2. Physiological $\mathrm{pO}_{2}$ have different effects on $\Delta \psi_{\mathrm{m}}$ in primary cultured astrocytes and

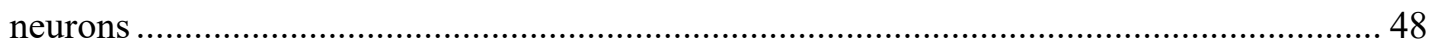


4.1.3. Physiological $\mathrm{pO}_{2}$ have different effects on mROS production in primary cultured astrocytes and neurons

4.2. Changes in mitochondrial structure of neurons and astrocytes at physiological $\mathrm{pO}_{2} 50$

4.2.1. Physiological $\mathrm{pO}_{2}$ modulated mitochondrial shapes in primary cultured astrocytes and neurons

4.2.2. Differential expression of mitochondrial structure-related genes in primary cultured astrocytes and neurons at $5 \% \mathrm{pO}_{2}$ compared to $21 \% \mathrm{pO}_{2}$

4.2.3. Structural organization of ETC in co-cultured neurons changed under physiological $\mathrm{pO}_{2}$

4.2.4. Reduced mRNA expression of ETC-related genes, in primary cultured astrocytes and neurons, at $5 \% \mathrm{pO}_{2}$ compared to $21 \% \mathrm{pO}_{2}$

4.3. Astrocytic or neuronal influence on the mitochondrial energy metabolism in neurons

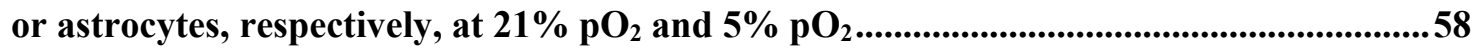

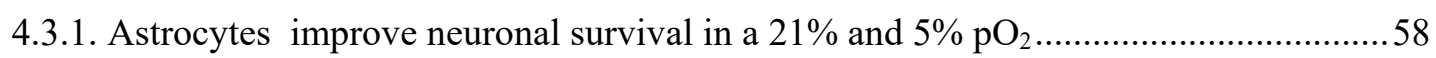

4.3.2. The presence of neurons keeps low astrocyte $\Delta \psi_{\mathrm{m}}$ in a $5 \% \mathrm{pO}_{2}$ atmosphere, but not at $21 \% \mathrm{pO}_{2}$.

4.3.3. Co-cultures of neurons and astrocytes significantly reduced the production mROS at $5 \% \mathrm{pO}_{2}$

4.3.4. Physiological $\mathrm{pO}_{2}$ reduced the expression of ETC and OxPhos subunits mRNA transcripts in co-cultured astrocytes and neurons

4.4. Effect of physiological $\mathrm{pO}_{2}$ on glucose metabolism in cultured neurons and astrocytes

4.4.1. Physiological $\mathrm{pO}_{2}$ increases glucose consumption and lactate production in cultured neurons and astrocytes

4.4.2. Physiological $\mathrm{pO}_{2}(5 \%)$ induced the expression of glycolysis-related mRNA transcripts in cultured neurons and astrocytes

4.4.3. Physiological $\mathrm{pO}_{2}$ increased glycolytic rates in neurons and astrocytes, as compared with the established $21 \% \mathrm{pO}_{2}$

4.4.4. Physiological $\mathrm{pO}_{2}(5 \%)$ induced the expression of glycolysis-related protein mRNA transcripts in co-cultured neurons and astrocytes

4.4.5. Reduction of $\mathrm{O}_{2}$ to physiological values increases glycolysis in co-cultured neurons but not in co-cultured astrocytes

4.4.6. Physiological $\mathrm{pO}_{2}$ increase the expression of Hexose Kinase II (HKII) protein in cocultured neurons.

4.4.7. Reduced expression and activity levels of HIF-1 $\alpha$ in co-cultured neurons at physiological $\mathrm{pO}_{2}$ 
4.4.8. Physiological $\mathrm{pO}_{2}$ reduces $\mathrm{AMPK}$ and $\mathrm{pAMPK}$ protein expression in co-cultured neurons

4.4.9. Physiological $\mathrm{pO}_{2}$ induces an increase in $\mathrm{ACC}$ protein expression but a reduced rate of phosphorylation in co-cultured neurons

4.4.10. Physiological $\mathrm{pO}_{2}(5 \%)$ reduces PPP related genes mRNA transcripts in co-cultured neurons and astrocytes, compared to $21 \% \mathrm{pO}_{2}$

4.4.11. Physiological $\mathrm{pO}_{2}$ reduces $6 \mathrm{PGDH}$ protein expression and activity in co-cultured neurons

4.4.12. Physiological $\mathrm{pO}_{2}$ increases mitochondrial $\mathrm{O}_{2}{ }^{--}$but reduces $\mathrm{H}_{2} \mathrm{O}_{2}$ in co-cultured neurons

4.4.13. Reduced expression of the mitochondrial manganese-dependent Superoxide

Dismutase (MnSOD; SOD2) at physiological $\mathrm{pO}_{2}$ in co-cultured neurons

4.4.14 Physiological $\mathrm{pO}_{2}$, in co-cultured neurons, induces changes in the levels of mRNA transcripts involved in energy metabolism.

4.4.15. Changes in cell cycle parameters of co-cultured neurons after incubation at physiological $\mathrm{pO}_{2}(5 \%)$, respect to the canonical $\mathrm{pO}_{2}(21 \%)$.

\section{5- Discussion} 86

5.1. Physiological $\mathrm{pO}_{2}$ improves survival and has differential effects on $\Delta \psi_{\mathrm{m}}$ and $\mathrm{mROS}$ production in neurons and astrocytes.

\subsection{Physiological $\mathrm{pO}_{2}$ modulates mitochondrial shapes and ETC}

\section{Complexes structural organization}

5.3. Increased glucose metabolism in cultured neurons and astrocytes under physiological $\mathrm{pO}_{2}$

5.4. $\mathrm{PPP}$ reduction and differential mROS and $\mathrm{H}_{2} \mathrm{O}_{2}$ production under physiological pO2

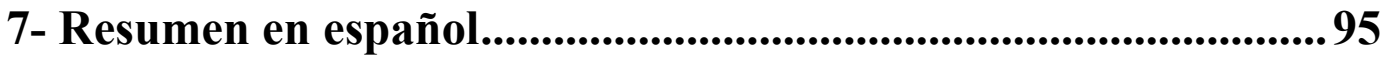

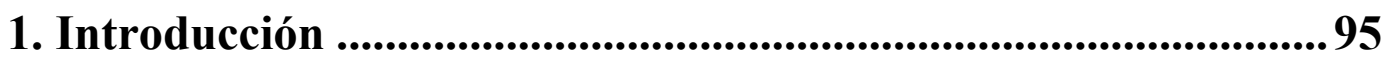

2. Hipótesis y objetivos. ...................................................................58

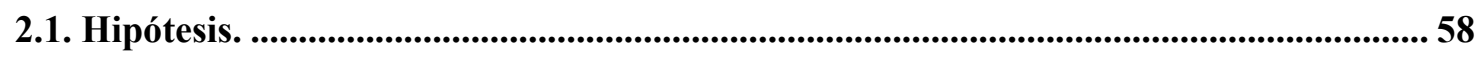

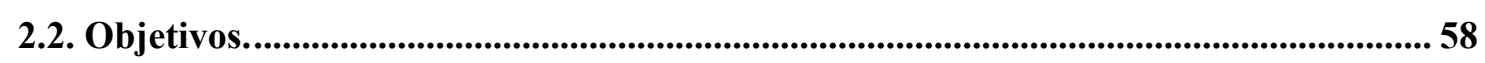

3. Resultados y Discusión ..............................................................59 
3.1. La $\mathrm{pO}_{2}$ fisiológica mejora la supervivencia y presenta efectos diferenciales sobre $\Delta \psi_{\mathrm{m}}$ y la producción de mROS en neuronas y astrocitos

\subsection{La $\mathrm{pO}_{2}$ fisiológica modula las formas mitocondriales y la} organización estructural de los complejos ETC 61

3.3. Aumento del metabolismo glucídico en neuronas y astrocitos cultivados bajo $\mathrm{pO}_{2}$ fisiológica. 63

3.4. Reducción de PPP y producción diferencial de $\mathrm{mROS} \mathrm{y} \mathrm{H}_{2} \mathrm{O}_{2}$ bajo $\mathrm{pO}_{2}$ fisiológica...65

4. Conclusiones 71

REFERENCES............................................................................... 73 


\section{List of abbreviations}

6-PGDH: 6-phosphogluconate dehydrogenase

7-AAD: 7-aminoactinomycin D

AD: Alzheimer's Disease

AIF: Apoptosis-Inducing Factor

AKAP121: A-Kinase Anchoring Protein 121

ALS: Amyotrophic Lateral Sclerosis

AMPK: AMP-activated protein Kinase

ANLS: Astrocyte-Neuron Lactate Shuttle

ARNT: Aryl hydrocarbon Receptor Nuclear Translocator

Asn: Asparagine

ATP: Adenosine Tri-Phosphate

BBB: Blood Brain Barrier

BCA: Bicinchoninic acid Assay also known as Smith assay

BNGE: Blue Native Gel Electrophoresis

BrdU: Bromodeoxyuridine

BSA: Bovine Serum Albumin

$\mathrm{CaCl}_{2} \cdot \mathbf{2 H}_{2} \mathrm{O}$ : Calcium Chloride Dihydrate

CBF: Cerebral Blood Flow

CBP: CREB-Binding Protein

CCCP: Carbonyl Cyanide m-Chlorophenyl Hydrazine

CK1: Casein Kinase 1

$\mathrm{ClO}_{4} \mathrm{H}$ : Perchloric Acid or PCA

CNS: Central Nervous System

Co-Q: Coenzyme Q, lipophyilic ubiquinone

COX: Cytochrome c Oxidase or mitochondrial complex IV

Cu/ZnSOD: Copper Zinc Superoxide Dismutase or SOD1

Cyt-C: Cytochrome C, hydrophilic hemeprotein

DIABLO: Direct Inhibitor of Apoptosis proteins Binding protein with Low pI

DiIC1(5): 1, 1',3,3,3', 3'-hexamethylindodicarbo-cyanine iodide

DNA: Deoxyribonucleic Acid

DRP1: Dynamin Related Protein

EBSS: Earle's Balanced Salt Solution 
EDTA: Ethylenediaminetetraacetic Acid

EPR: Electron Paramagnetic Resonance

ETC: Electron Transport Chain

EAAT: Excitatory Amino Acid Transporters

F2,6P2: Fructose 2,6-bisphosphate

FCS: Fetal Calf Serum

FeS: Iron-Sulfur

FMN: Flavin mononucleotide

G6P: Glucose-6-phosphate

G6PD: Glucose-6-phosphate Dehydrogenase

GCL: Glutamate Cysteine Ligase

GLUT: Glucose Transporter

GPx: Glutathione Peroxidase

GR: Glutathione Reductase

GSH: Glutathione

GSSG: Glutathione disulide

GST: Glutathione S-Transferase

$\mathrm{H}_{2} \mathrm{O}_{2}$ : Hydrogen peroxide

HBSS: Hank'S Balanced Salt Solution

HeLa cells: Cervical cancer immortal cell line taken from Henrietta Lacks, a patient died of cancer

HEPES: 4-(2-hydroxyethyl)-1-piperazineethanesulfonic acid

HIF: Hypoxia Inducible Factor

HK: Hexokinase

HMIT: H+-driven Myoinositol

HO $^{*}$ : Hydroxyl radical

HRE: Hypoxia Responsive Elements

HtrA2: High temperature-requiring proteins

KCl: Potassium Chloride

KH2PO4: Potassium Phosphate, monobasic

KOH: Potassium Hydroxide

LDH: Lactate Dehydrogenase

MAO: Minus Antioxidants 
MAPK: Mitogen Activated Protein Kinase

MCA: Middle Cerebral Artery

MCT: Monocarboxylate Transporter

MEFs: Mouse Embryonic Fibroblasts

MFN: Mitofusins

mGluR: Metabotropic Glutamate Receptor

$\mathrm{MgSO}_{4}$ : Magnesium Sulfate

MNRR1: Mitochondria Nuclear Retrograde Regulator

MnSOD: Manganese Superoxide Dismutase or SOD2

MOPS: 3-(N-morpholino)propanesulfonic acid

MRC: Mitochondrial Respiratory Chain

mRNA: messenger RNA or messenger Ribonucleic Acid

$\mathrm{Na}_{2} \mathrm{CO}_{3}$ : Sodium Carbonate

$\mathbf{N a}_{2} \mathbf{H P O}_{4}$ : Disodium Phosphate or sodium hydrogen phosphate or sodium phosphate dibasic

$\mathrm{Na}_{2} \mathrm{PO}_{4}$ : Disodium Phosphate

NaCl: Sodium Chloride

NAD: Nicotinamide Adenine Dinucleotide in oxidized form

NADH: Nicotinamide Adenine Dinucleotide in reduced form

NADP: Nicotinamide Adenine Dinucleotide Phosphate

NADPH: Nicotinamide Adenine Dinucleotide Phosphate reduced form

NaF: Sodium Fluoride

$\mathrm{NaH}_{2} \mathrm{PO}_{4}$ : Monosodium Phosphate also known as monobasic sodium phosphate

$\mathrm{NaHCO}_{3}$ : Sodium Bicarbonate or sodium hydrogen carbonate

NDUFA5: NADH Ubiquinone Oxidoreductase Subunit A5

NDUFS1: NADH Ubiquinone Oxidoreductase Core Subunit S1

NOS: Nitric Oxide Synthase

NTBZ: Nitro Blue Tetrazolium chloride

NVC: Neurovascular coupling

$\mathbf{O}_{2}^{-}$: Superoxide anion

ODD: Oxygen-Dependent Degradation region

ONOO-: Peroxynitrite anion

OPA1: Dynamin-related GTPase Optic Atrophy 1

OXPHOS: Oxidative Phosphorylation 
PAS: Per-ARNT-Sim

$\mathbf{P b}\left(\mathrm{NO}_{3}\right)_{2}$ : Plumbous nitrate or Lead (II) Nitrate

PBS: Phosphate-Buffered Saline

PD: Parkinson's Disease

PDL: Poly-D-Lysine

PFK1: Phosphofructo-1-kinase

PFKFB3: 6-phosphofructo-2-kinase/fructose2,6-bisphosphatase, isoform

PHD: Prolyl 4-hydroxylase

PKD1: Protein Kinase D1

pO$_{2}$ : Oxygen partial pressure

PPP: Pentose Phosphate Pathway

PS: Phosphatidylserine

PTP: Permeability Transition Pore

PVDF: Polyvinylidene Difluoride

R5P: Ribulose-5-phosphate

RCF: Relative Centrifugal Field

RIPA: Radioimmunoprecipitation assay buffer

ROS: Reactive Oxygen Species

RT-qPCR: Real Time quantitative quantitative Polymerase Chain Reaction

SCs: Super-Complexes also known as respirasomes

SDH: Succinate Dehydrogenase

SDS-PAGE: Sodium Dodecylsulfate-polyacrylamide Gel Electrophoresis

Smac: Second mitochondrial activator of caspases

SOD: Superoxide Dismutase

SP1 trasncription factor: Specifity Protein 1, a zinc finger transcription factor

TAD: Transcription Activation Domains

TCA: Tricarboxylic Acid also known as citric acid cycle

TrxR: Thioredoxin Reductase

VHL: Von Hippel-Lindau

$\boldsymbol{\gamma}$-GluCys: Dipeptide $\boldsymbol{\gamma}$-glutamylcysteine

$\Delta \psi \mathrm{m}:$ Mitochondrial membrane potential 



\section{1- Introduction}

\subsection{Oxygen in the central nervous system}

\subsubsection{Oxygen levels in the brain}

The mammalian brain is a highly energy-consuming organ, completely reliant on molecular oxygen to maintain its functions, however, oxygen can also be dangerous due to toxicity. Oxygen levels $\left(\mathrm{O}_{2}\right.$ partial pressure or $\left.\mathrm{pO}_{2}\right)$ in mammalian brain under physiological conditions have been reported to range from $1 \%$ to $10 \%$. The values obtained over the years (1961-2017) in different representative studies across species are listed in Table 1. Several units are used to define $\mathrm{pO}_{2}$. In the international system, the pressure unit is the Pascal $(\mathrm{Pa})$. Other units include the bar $(1 \mathrm{bar}=100 \mathrm{kPa})$, the atmosphere $(1 \mathrm{~atm}=101.325 \mathrm{kPa})$, the Torr $(1$ torr $=133.322 \mathrm{~Pa})$ and two units mostly used in medicine: the millimetre of mercury $(1 \mathrm{mmHg}=1$ torr $=133.322 \mathrm{~Pa})$ and the percentage of oxygen $(1 \%=0.01 \mathrm{~atm}=1.013$ $\mathrm{kPa})$.

To illustrate the actual oxygen levels in the brain, we refer the work of Devor et al. (fig. 1) who, by the use of a two-photon microscopy method, they describe a gradient of $\mathrm{pO}_{2}$ around diving arterioles that decreased with depth from $\sim 80 \mathrm{mmHg}\left(10.04 \% \mathrm{pO}_{2}\right)$ at $<100 \mu \mathrm{m}$ to $\sim 55 \mathrm{mmHg}\left(7.15 \% \mathrm{pO}_{2}\right)$ at $>200 \mu \mathrm{m}$, and smaller gradients around the majority of surfacing venules (fig. 1). They also demonstrated, that a stimulus evoking an increase in blood oxygenation during the hemodynamic response prevents a subsequent drop in oxygenation, maintaining a baseline tissue oxygenation at tissue locations that are distal from the vascular feeding sources (Devor et al., 2011). More recently, the work of Xu et al. (2017), determined $\mathrm{pO}_{2}$ within the cerebral cortex of mice to a depth ranging between $200-250 \mu \mathrm{m}$, under normoxia and acute hypoxia, using two-photon phosphorescence lifetime microscopy. Data showed that $\mathrm{pO}_{2}$ was in the range of $20-60 \mathrm{mmHg}(2.6-7.8 \%$ $\mathrm{pO}_{2}$ ) for normoxia and $2-18 \mathrm{mmHg}\left(0.26-2.34 \% \mathrm{pO}_{2}\right)$ for hypoxia. 


\begin{tabular}{|c|c|c|c|}
\hline Animal species (region) & $\begin{array}{l}\text { Method of data } \\
\text { expression }\end{array}$ & $\mathrm{pO}_{2} \mathrm{kPa}(\mathrm{mmHg})$ & Reference \\
\hline Rat & & & (Cater et al., 1961) \\
\hline Cortex (grey) & Range & $2.53-5.33(19-40)$ & \\
\hline Cortex (white) & Range & $0.80-2.13(6-16)$ & \\
\hline Hypothalamus & Range & $1.47-2.13(11-16)$ & \\
\hline Pons, fornix & Range & $0.13-0.40(1-3)$ & \\
\hline Hippocampus & & $2.67(20.3)$ & \\
\hline Hippocampus near pia & & $4.40(33)$ & \\
\hline Hypothalamus & Range & $1.47-2.13(11-16)$ & \\
\hline Midbrain & Range & $0.55-1.07(4.1-8.0)$ & \\
\hline Pia & & $8.0(60)$ & \\
\hline In third ventricle & & $4.93(37)$ & \\
\hline Cat & & & (Nair et al., 1975) \\
\hline Cortex & Histogram & $0-13.2(0-99)$ & \\
\hline & Mean \pm S.D. & $\begin{array}{l}5.16 \pm 3.07(38.7 \pm \\
23)\end{array}$ & \\
\hline Rabbit & & & (Smith et al., 1977) \\
\hline Cortex & Histogram & $0-12(0-90)$ & \\
\hline & Mean \pm S.D. & $\begin{array}{l}3.27 \pm 2.40(24.5 \pm \\
18)\end{array}$ & \\
\hline Rabbit & & & (Seylaz \& Pinard, 1978) \\
\hline Caudate nucleus & Range & $0.84-3.47(6.3-26)$ & \\
\hline & Mean \pm S.D. & $\begin{array}{l}2.25 \pm 0.77(16.9 \pm \\
5.76)\end{array}$ & \\
\hline Piglet & & & (Wilson et al., 1991) \\
\hline Cortex blood vessels & $\begin{array}{l}\text { Range of } \\
\text { means }\end{array}$ & $3.33-4.67(25-35)$ & \\
\hline Rat & & & (K. J. Liu et al., 1995) \\
\hline Cortex & Mean \pm S.D. & $4.54 \pm 0.75(34.1 \pm 5.6)$ & \\
\hline Rat & & & (LaManna, 2007) \\
\hline Cortex & $\begin{array}{l}\text { Histogram } \\
\text { Mean } \pm \text { S.D. }\end{array}$ & $\begin{array}{l}0-6.3(0-47) \\
1.2 \pm 1\end{array}$ & \\
\hline Rat & & & $\begin{array}{l}\text { (Devor et al., } \\
\text { 2011) }\end{array}$ \\
\hline Cortex diving arterioles & Range & $1.33-10.6(10-80)$ & \\
\hline Cortex surfacing venules & Range & $0.67-2.67(5-20)$ & \\
\hline Mice & & & (Xu et al., 2017) \\
\hline Cortex & Range & $2.67-8(20-60)$ & \\
\hline
\end{tabular}

Table 1. Regional pO2 values in brain. From 1961-1995, Erecinska \& Silver (2001). Thereafter, this thesis. 

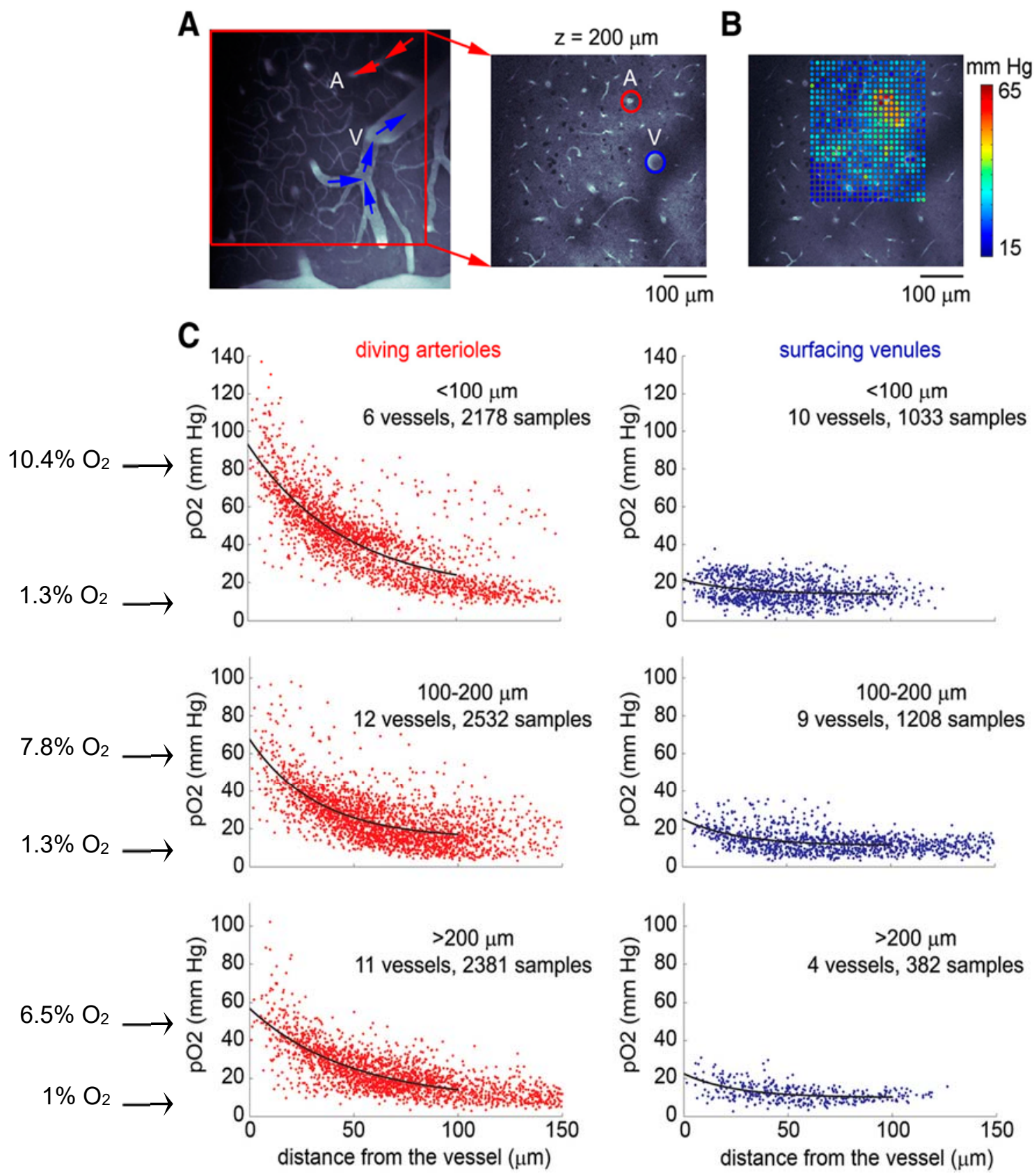

Figure 1. Baseline pO2 relative to diving arterioles and surfacing venules. Adapted from (Devor et al., 2011). 


\subsubsection{Brain energy supply:}

The adult human brain has a very high energy demand compared to the rest of the body. Thus, while the brain comprises only $2 \%$ of the body weight, it consumes $20 \%$ of the total energy in the body (Ashrafi \& Ryan, 2017; Sokoloff, 1960). This high energy demand is supplied by a well-established network of cerebral vasculature (fig. 2). Interconnected pial arteries, covered by multiple layers of vascular smooth muscle cells, constitute a network that lie on the surface of the cortex (Mishra, 2017). The surface network is connected to an underlying, three-dimensional network of micro-vessels by radially directed penetrating arterioles.

A cerebral autoregulation process takes place to maintain stable the cerebral perfusion and oxygenation against changes in arterial blood pressure (Kisliakov et al., 1983; Tzeng \& Ainslie, 2014). Despite this regulatory mechanism, increases in neuronal activity trigger brain arterioles dilatation producing blood flow increase, a response termed 'functional hyperemia' (Newman, 2013). This coupling between neuronal activity and cerebral blood flow, also called neurovascular coupling (NVC), was first described by Mosso in 1880, an Italian physiologist who first tried to experimentally measure the increase of blood flow that occurs during brain activity as around when switching from the resting state to cognitive activity (Sandrone et al., 2014). This was highlighted by William James when he was introducing the concept of changes in brain blood flow during mental activities, then characterised by Roy and Sherrington in the same year (1890) as described by (Friedland \& Iadecola, 1991). NVC has now became an accepted fundamental aspect of brain function, in which astrocytes play a central pivotal role (Adriani et al., 2017; Yamada, 2016) . 

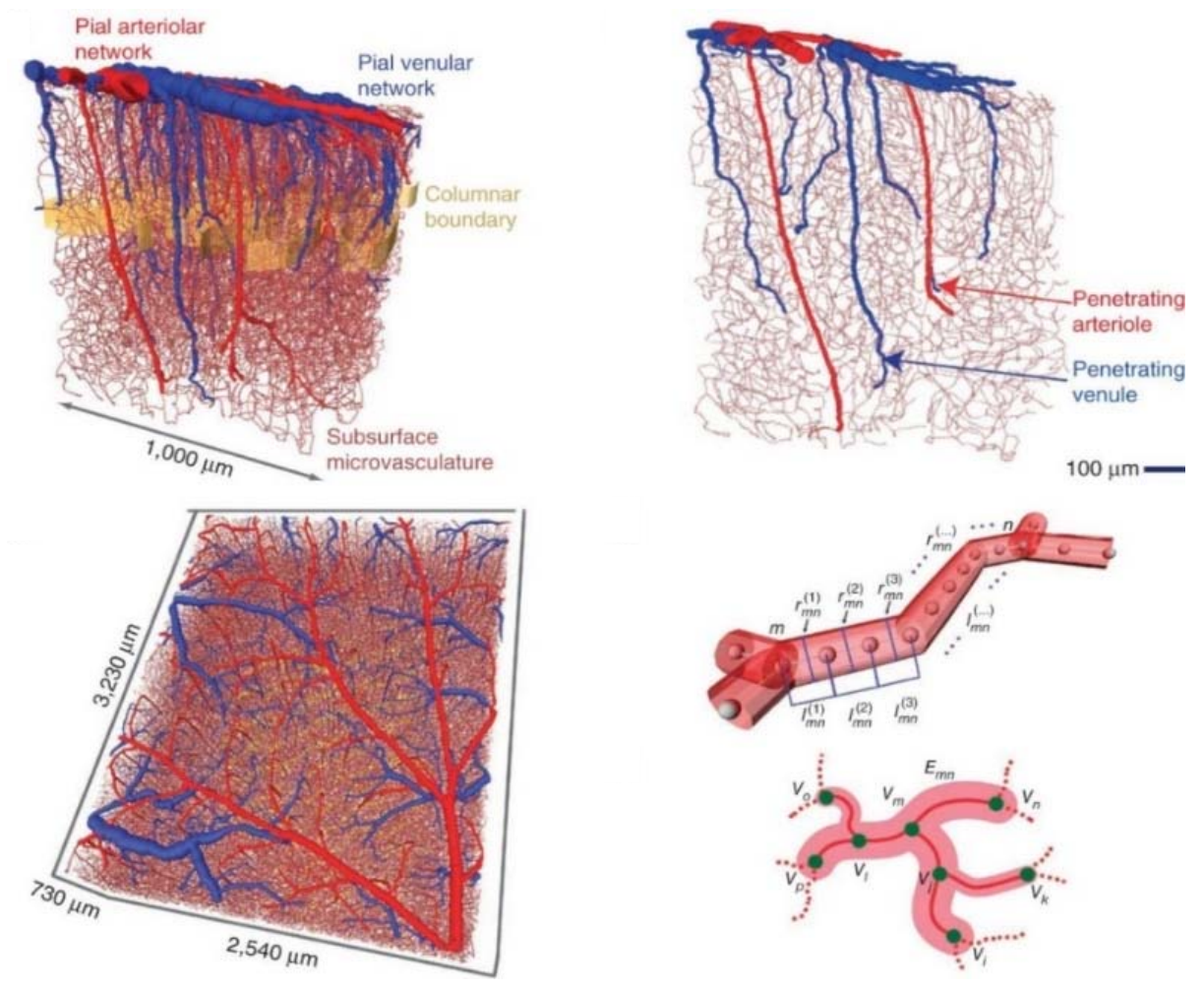

Figure 2. Vascular network reconstruction obtained throughout the full depth of cortex (Blinder et al., 2013).

\subsubsection{Astrocytes and neurovascular coupling}

Astrocytes are the second most abundant brain cell type and the major glial cell type in the central nervous system. They have numerous functions and have attracted a high interest over the last decade. The traditional notion of the functional role of astroglial cells has been limited to nutritional and structural support to neurons. However, astrocytes besiege neuronal bodies and make contacts with thousands of synapses (Papouin et al., 2017), where they sense the neuronal activity, fine-tune synaptic transmission and actively participate to neurotransmitter clearance from the synaptic clefts (Murphy-Royal et al., 2017). At the same time, they embrace all types of intracerebral arterioles, capillaries and veins controlling the traffic of chemicals and nutrients from and into the blood stream (McCaslin et al., 2011) and maintains the ionic homeostasis (Liberto et al., 2004; Simard $\&$ Nedergaard, 2004). Therefore, this interaction with the vasculature forms a gliovascular network that might organize not only the structural architecture of the brain, but also its communication pathways.

In addition, astrocytes can affect the activity of vascular smooth muscle cells, since the penetrating arterioles are surrounded by astrocytic end-feet (fig. 3) (Iadecola, 2004; Nedergaard et al., 2003). In vitro slice studies have shown that activation of astrocytes can 
produce either vasodilation or vasoconstriction of brain arterioles (Blanco et al., 2008). However, the glial control of the cerebral vasculature appears to depend on the pre-existing tone of the vessel and, most importantly, on tissue $\mathrm{O}_{2}$ concentration (Gordon et al., 2008; Mishra, 2017). In hippocampal slices, at hyperoxic conditions $\left(21 \% \mathrm{pO}_{2}\right)$, direct activation of astrocytes by $\mathrm{Ca}^{2+}$ uncaging or activation of metabotropic glutamate receptors (mGluRs), has been shown to evoke arteriole vasoconstriction (Mulligan \& MacVicar, 2004), whereas under lower $\mathrm{O}_{2}$ conditions (hypoxia) leads to vasodilation (Blanco et al., 2008). This suggests that tissue $\mathrm{pO}_{2}$ level is one of the main factors that determine the cerebrovascular responses to astroglial activation (Angelova et al., 2015) and, therefore, needs to be studied in detail.

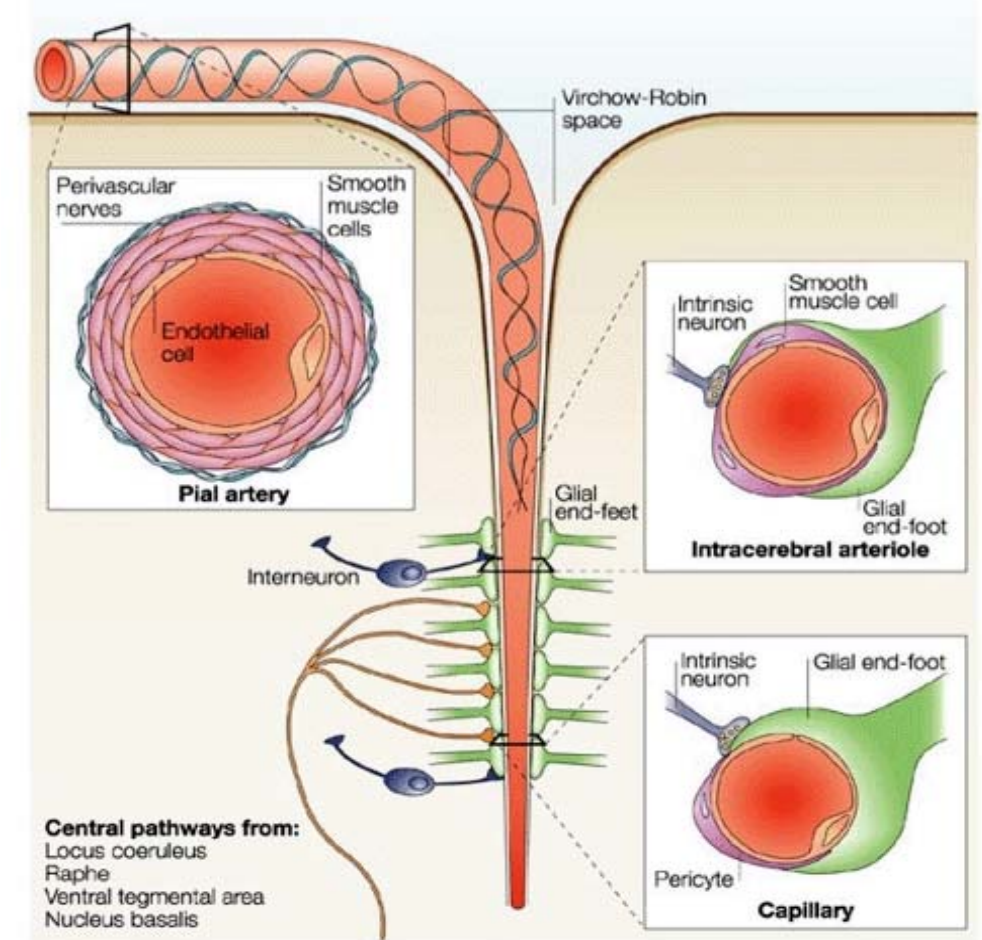

Figure 3. Neurovascular unit: parenchymal arterioles associated with neurons and astrocytes. From (Iadecola, 2004).

\subsubsection{Adaptation of the brain to acute and chronic exposure to hypoxia}

Since mammals live in diverse environmental niches, they are exposed to variable ambient oxygen levels and they require numerous intrinsic and extrinsic regulatory mechanisms to maintain an appropriate level of oxygen availability to the central nervous system (LaManna, 2007). Hypoxia refers to any reduction in the availability of oxygen at any baseline situation. By general use, the term "hypoxia" refers to any drop in the air $\mathrm{pO}_{2}$ at the sea level, which is $21 \mathrm{kPa}(21 \%)$ (Peacock, 1998). In normal physiology, the $\mathrm{pO}_{2}$ in the 
inspired air is $\sim 19,6 \mathrm{kPa}$ and in pulmonary vein is $\sim 14 \mathrm{kPa}$ due to the contribution of water vapour and carbon dioxide (Kisliakov Iu \& Ivanov, 1976; LaManna, 2007; Peacock, 1998). During acute hypoxia, e.g. pulmonary vein $\mathrm{pO}_{2}$ below $12 \mathrm{kPa}$ (but above $6 \mathrm{kPa}$ ), $\mathrm{pO}_{2}$ can be compensated for by physiological processes and does not lead to tissue damage. However, when it falls below $4 \mathrm{kPa}$, hypoxia is severe and results in loss of consciousness and neuronal degeneration (LaManna, 2007). The regulation of cerebral blood flow (CBF) is a robust mechanism. Acute exposure to hypoxia causes an immediate increase in CBF which is curvilinear with respect to arterial $\mathrm{pO}_{2}$ and linear with respect to haemoglobin saturation (fig. 4) (Poulin, 1998; Sick et al., 1982). In humans, middle cerebral artery (MCA) blood flow velocity increases $0.35-0.75 \mathrm{~cm} / \mathrm{s}$ for every $1 \%$ decrease in blood oxygen saturation (Ainslie \& Poulin, 2004; Hohenhaus et al., 1995; Hypoxia: Translation in Progress, 2016).

When exposed to a prolonged mild hypoxia, an adaptation takes place at three main levels: the lung, the circulation and the affected tissue. The changes in the lung include an increase in diffusing capacity (Burri \& Weibel, 1971; Calbet et al., 2016; Weibel, 2017), an increase in ventilation (Wilson et al., 2005), pulmonary vasoconstriction and hypertension, and vascular remodelling (Howell et al., 2003; Rey et al., 2017). The changes in the circulation include enhanced cardiac output, an increased haemoglobin concentration and hence a right-shifted haemoglobin saturation curve previous to a cardiac output normalizing (Siebenmann \& Lundby, 2015).Tissue adaptations include increased capillary surface area, decreased energy demand and increased energy production efficiency (LaManna, 2007).

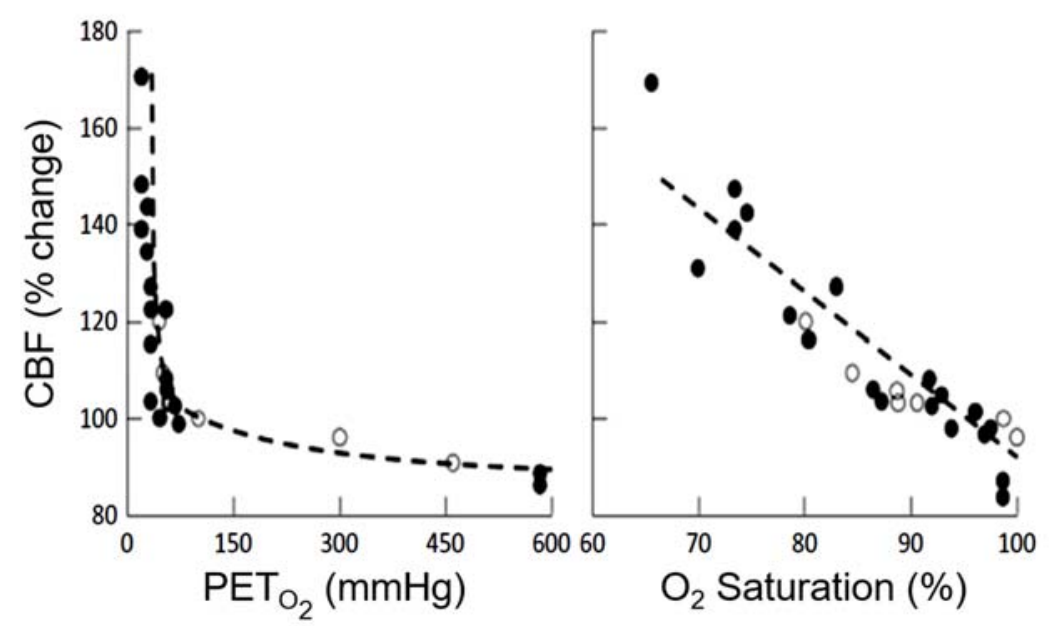

Figure 4. The CBF response to hypoxia. PETo 2 : end-tidal p $\mathrm{O}_{2}$. From (Hypoxia, 2016; Poulin, 1998). 


\subsubsection{Hypoxia responsive factors}

\subsubsection{Structure and function}

Hypoxia upregulates various transcription factors and chaperone proteins (fig. 6). Three hypoxia inducible factors (HIFs) have been described to date that modulate inducible gene expression as a response to hypoxia. HIFs are heterodimeric transcription factors composed of an alpha subunit (HIF-1 $\alpha$, HIF-2 $\alpha$, or HIF-3 $\alpha$ ) and a beta subunit (HIF-1 $\beta$, also called Aryl hydrocarbon Receptor Nuclear Translocator or ARNT). HIF-1 (HIF-1 $\alpha /$ ARNT) and HIF-2 (HIF-2 $\alpha$ ARNT) are widely expressed, being HIF-1 $\alpha$ as the most ubiquitously expressed and best characterised of the family and is considered as a master regulator of hypoxic signalling (Mata-Greenwood et al., 2017; Semenza, 2004; Thomas et al., 2017). Conversely, expression of HIF-3 (HIF-3 $\alpha$ /ARNT) is restricted only to highly vascularized tissues as thymus, lung, brain, heart, and kidney (Hara et al., 2001). HIFs use a basic helixloop-helix (bHLH) domain to bind consensus DNA binding motifs (hypoxia-responsive elements: HRE) within regulatory promoter regions of hypoxia-responsive genes (fig. 5) (Cummins et al., 1993). They also contain two sequential PAS (Per-ARNT-Sim) domains to dimerize with Hif1- $\beta$, and two transcription activation domains (TAD), one located in the N-terminal (N-TAD) and in the C-terminal (C-TAD) of the transactivation region. A region named Oxygen-Dependent Degradation region (ODD), which overlaps the N-TAD, is responsible for the protein degradation in response to hydroxylation of two conserved prolines (Wigerup et al., 2016).

HIF-3 $\alpha$ is less characterized and its sequence identities with HIF-1 $\alpha /$ HIF- $2 \alpha$ are relatively low (Gu et al., 1998). The HIF-3 $\alpha$ genes are subjected to complex regulation and produce a large number of mRNA variants due to the utilization of different promoters, different transcription initiation sites, and alternative splicing in mammals (Prabhakar \& Semenza, 2012). The full-length HIF-3 $\alpha$ protein functions as an oxygen-regulated transcription activator while some short HIF-3 $\alpha$ variants act as dominant-negative regulators of HIF1/2 $\alpha$ actions (Duan, 2016; Yang et al., 2015). 


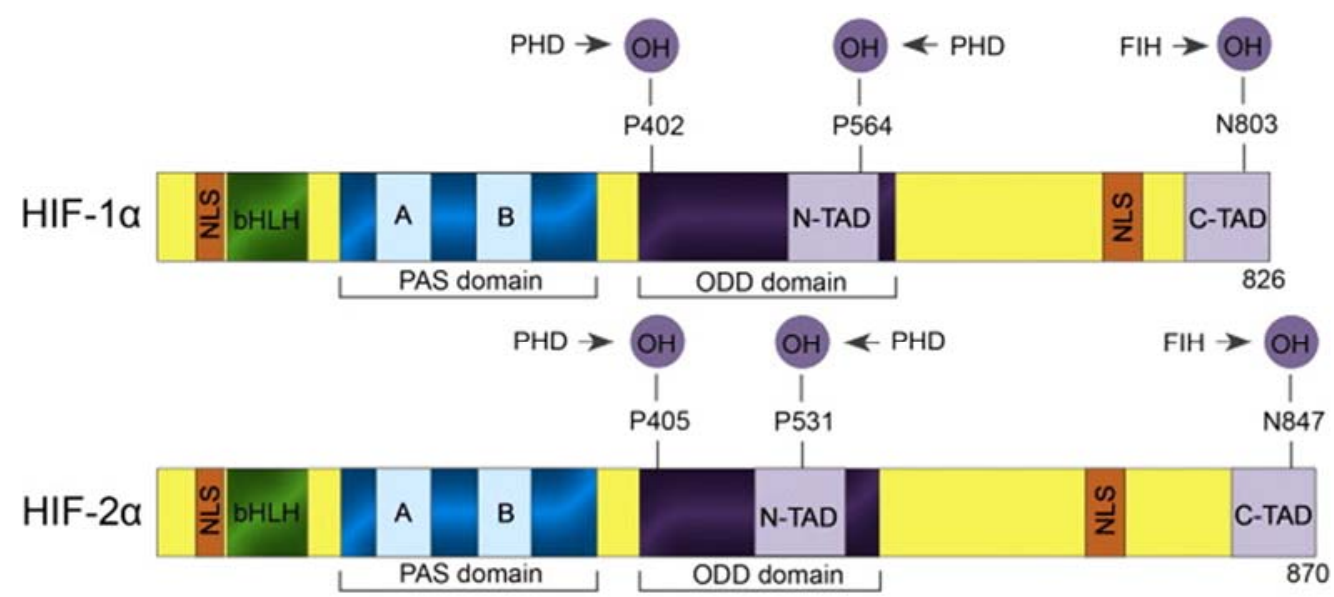

Figure 5. Domain structures of HIF- $\alpha$ isoforms (from Wigerup et al. 2016).

\subsubsection{2 $\mathrm{O}_{2}$ regulation of HIFs stability}

Under normoxia, HIF-1 $\alpha$ has a very short half-life (about 5-10min) (Salceda \& Caro, 1997). Its stability is disrupted by prolyl 4-hydroxylases (PHDs) which are dioxygenases that utilize oxygen as co-substrate, assuring the molecular basis for the oxygen-sensing function of these enzymes. When oxygen is available, PHDs become activated and hydroxylate two highly conserved prolines (Pro402 and Pro564) in the oxygen-dependent degradation domain (ODD) of HIF $\alpha$ subunits, which are afterward recognized by the von HippelLindau (VHL) factor, a component in the multiprotein E3 ubiquitin ligase complex that marks them for proteosomal degradation (fig. 7) (Jaakkola et al., 2001). At low $\mathrm{O}_{2}$ levels HIFs $\alpha$ subunits become stabilized and they translocate into the nucleus, where they dimerize with the $\beta$-subunits acquiring transcriptional activity (Kaluz et al., 2008).

\subsubsection{3 $\mathrm{O}_{2}$ regulation of HIFs transcriptional activity}

In addition to HIF $\alpha$ subunits protein stability, transcriptional activity of the $\alpha$ subunits can also be modulated by $\mathrm{pO}_{2}$. The "Factor Inhibiting HIF" (FIH) is an asparaginyl hydroxylase which binds to the inhibitory (IH) domain of HIF-1 $\alpha$ and HIF-2 $\alpha$ proteins and results in hydroxylation of an asparagine residue located in the HIF $\alpha$ carboxylic termini of transactivation domains (C-TAD; N813 of HIF-1 $\alpha$, N851 of HIF-2 $\alpha$ ). This Asn hydroxylation inhibits HIF transcriptional activity, even when HIF $\alpha$ protein is stabilized.

\subsubsection{Regulation by post-translational modification}

A number of post-translational modifications of HIFs, including phosphorylation, acetylation, S-nitrosylation and others have been described to date (for a review see Keith 
et al. (2011) ). These covalent modifications have different effects depending on the HIF$\alpha$ subunit involved. Thus, protein kinase D1 (PKD1)-dependent phosphorylation of Thr324 of HIF- $2 \alpha$ inhibits HIF-2 $\alpha$ from binding to SP1 transcription factor, whereas HIF- $1 \alpha$ is not phosphorylated by PKD1 because it lacks in that threonine. Phosphorylation of Hif-1 $\alpha$ by other kinases have been described and include the mitogen activated protein kinase (MAPK), and casein kinase 1 (CK1) among others, with the consequent modulation of HIF$1 \alpha$ localization and activity (Keith et al., 2011).

Both HIF-1 $\alpha$ and HIF-2 $\alpha$ are deacetylated by some members of the sirtuins family (SIRT17) with opposite effects depending on the type of $\alpha$ subunit. After SIRT1 dependent deacetylation, transcriptional activity of HIF- $2 \alpha$ increases but the activity of HIF- $1 \alpha$ is reduced. Also, some works indicate that both HIF-1 $\alpha$ and HIF-2 $\alpha$ can modulate expression of SIRT1 by mechanisms that are not yet completely understood (Keith et al., 2011; Pawlus \& Hu, 2013).

\subsubsection{HIFs targets}

Hypoxia causes HIF-1 to regulate $>70$ genes involved in tumour metabolism, angiogenesis, proteolysis, tissue remodelling, cell proliferation, apoptosis, glucose metabolism and erythropoiesis. HIF-2 $\alpha$ is similar to HIF-1 $\alpha$ in the regulation of some genes (see table 2; (Keith et al., 2011)). Activated $\alpha$ subunits bind to the target gene promoter in HRE, and regulates transcription in collaboration with other transcription factors, such as $\mathrm{CBP} / \mathrm{p} 300$ (fig. 7) (Arany et al., 1996; Masoud \& Li, 2015).

\subsubsection{HIFs action mechanism related to low $\mathrm{pO}_{2}$}

Lee and colleagues have showed that inhibition of mitochondrial respiration promotes longevity by elevating reactive oxygen species (ROS) levels and increasing HIF-1 activity (Lee et al., 2010). These authors have also shown that HIF-1 and AMPK activities are interconnected and both are increased in response to mild inhibition of mitochondrial respiration (Hwang et al., 2014). According to their model, an increase in ROS may initially elevate HIF-1 levels, resulting in further amplification of internal ROS. AMPK then may be inhibited by HIF-1 to prevent a futile cycle that simultaneously activates positive and negative feedback regulators of ROS. After the initial amplification of ROS via HIF-1, ROS levels may be sufficient to increase AMPK activity, overriding the downregulation of AMPK by HIF-1. Activated AMPK then may reduce the levels of ROS and HIF-1 to protect animals from toxic levels of ROS. 


\begin{tabular}{|c|c|c|c|c|}
\hline Gene & Function & HIF1 $\alpha$ & HIF $2 \alpha$ & Cell type \\
\hline GLUT1 & Glucose transport & + & + & RCC, mouse ES \\
\hline ADRP & Lipid metabolism & + & + & $\mathrm{RCC}$ \\
\hline CAXII & $\mathrm{pH}$ homeostasis & + & + & $\mathrm{RCC}$ \\
\hline FILAG & Cytoskeletal structure & + & + & $\mathrm{RCC}$ \\
\hline IL-6 & Immune cytokine & + & + & $\mathrm{RCC}$ \\
\hline ADM1 & Angiogenesis & + & + & $\mathrm{RCC}$ \\
\hline VEGF & Angiogenesis & + & + & RCC, Нер3B \\
\hline VEGF & Angiogenesis & + & - & Mouse EC, mouse ES \\
\hline BNIP3 & Autophagy, apoptosis & + & - & $\mathrm{RCC}$ \\
\hline HK1 & Glycolysis & + & - & Mouse ES \\
\hline HK2 & Glycolysis & + & - & RCC, mouse ES \\
\hline PFK & Glycolysis & + & - & RCC, mouse ES \\
\hline ALDA & Glycolysis & + & - & RCC, mouse ES \\
\hline PGK1 & Glycolysis & + & - & RCC, mouse ES \\
\hline LDHA & Glycolysis & + & - & RCC, mouse ES \\
\hline INOS & NO production & + & - & Macrophages \\
\hline ARG & Inhibitor of NO production & - & + & Macrophages \\
\hline EPO & Erythropoiesis & - & + & Kidney, liver \\
\hline OCT4 & Stem cell identity & - & + & Mouse ES \\
\hline SCGB3A1 & Secretoglobin 3A1 & - & + & NSCLC \\
\hline TGF $\alpha$ & Growth Factor & - & + & $\mathrm{RCC}$ \\
\hline CCND1 & Cell cycle progression & - & + & $\mathrm{RCC}$ \\
\hline DLL4 & $\begin{array}{l}\text { NOTCH signaling, EC } \\
\text { branching }\end{array}$ & - & + & Mouse ECS \\
\hline ANG2 & Blood vessel remodeling & - & + & Mouse ECS \\
\hline
\end{tabular}

Table 2. Representative shared and unique target genes regulated by HIF1 $\alpha$ and HIF2 $\alpha$ (adapted from Keith et al. 2012 (Keith et al., 2011). RCC, Renal Cell Carcinoma; mouse ES, mouse Embryonic Stem cells; Hep3B, Human hepatoma cell line; NSCLC, Non-Small-Cell Lung Cancer; Mouse ECs, Mouse Endothelial Cells. 


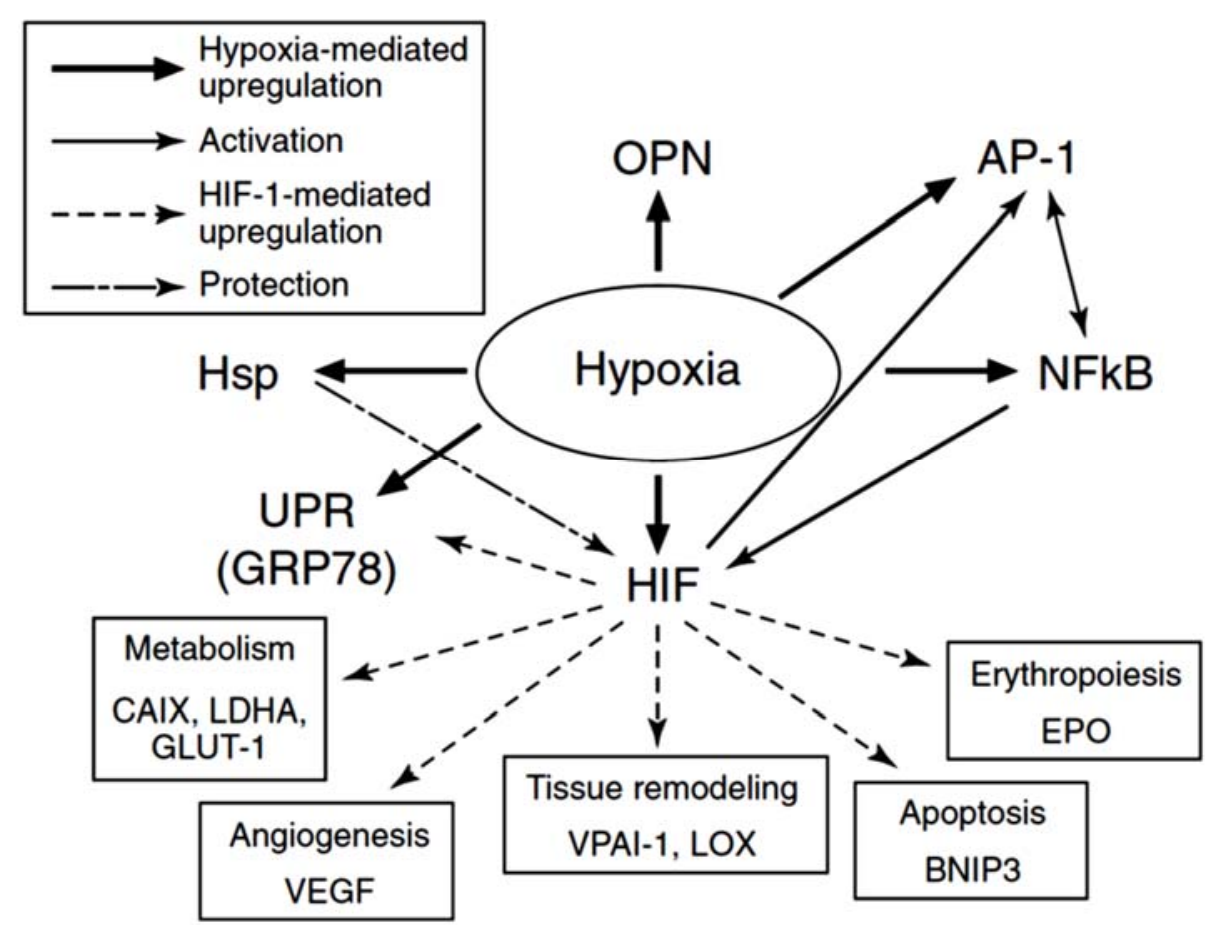

Figure 6. Transcription factors and chaperone proteins upregulated by hypoxia. Moon et al., (2007).

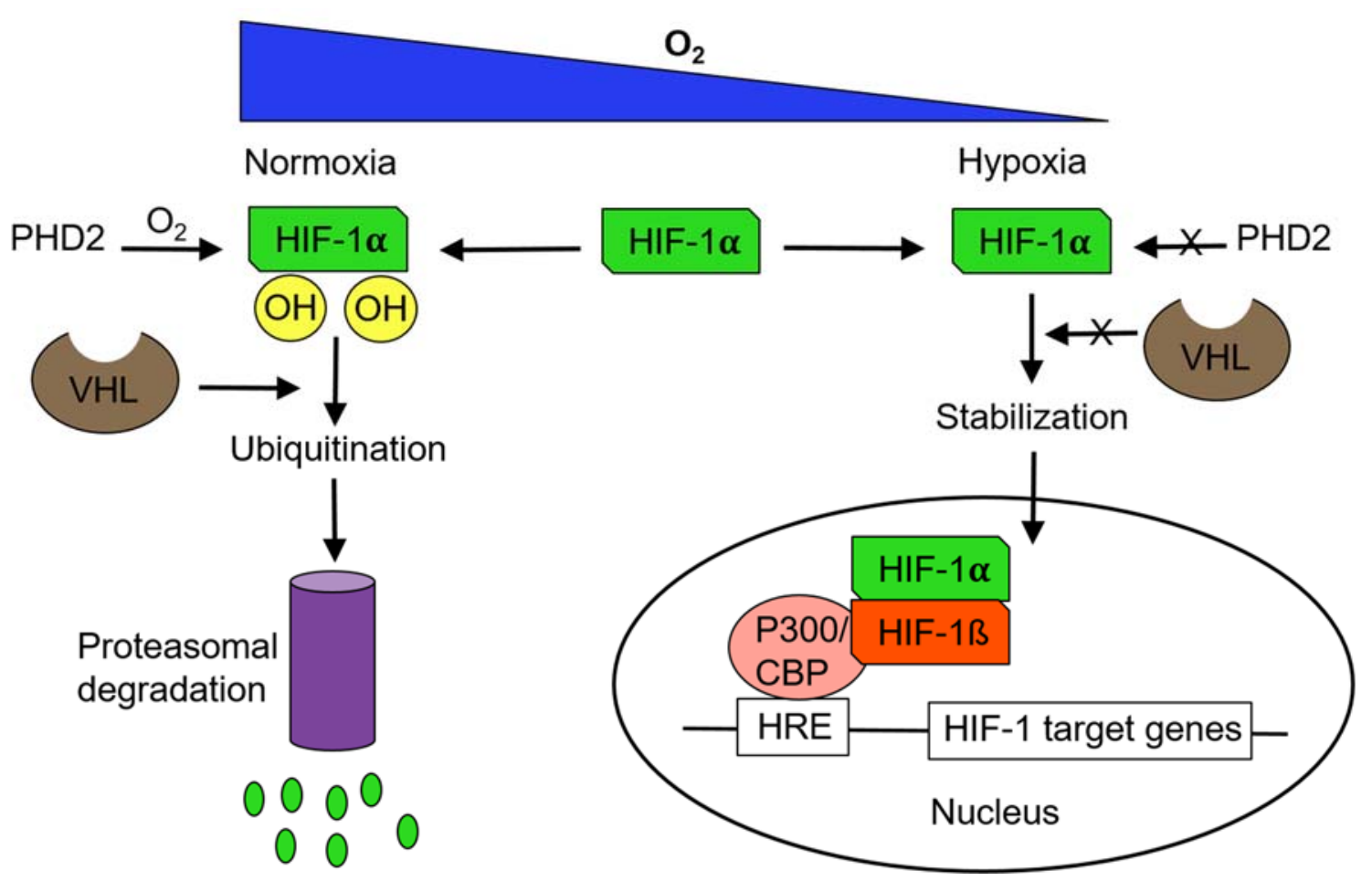

Figure 7. HIF-1a cellular pathway. 


\subsection{Mitochondria in the brain}

\subsubsection{Mitochondrion}

The mitochondrion, considered as the powerhouse of the cell, primarily responsible for the production of adenosine triphosphate (ATP) as well as playing regulatory roles in cell death, including autophagy and apoptosis. The Tricarboxylic Acid Cycle (TCA), the Electron Transport Chain (ETC) and the Oxidative Phosphorylation (OXPHOS) are among the key oxidative metabolic pathways that operate in mitochondria.

\subsubsection{The Mitochondrial Respiratory Chain (MRC)}

In mammals, ETC is formed by four multi-protein enzyme complexes (CI to CIV) and two mobile electron carriers: the coenzyme Q (Co-Q; lipophilic ubiquinone) embedded in the mitochondrial inner membrane and the cytochrome c (Cyt-C; hydrophilic hemeprotein), freely moving in the intermembrane space (fig. 8). ETC facilitates electron transfer from reducing equivalents to molecular oxygen coupled to the generation of a proton gradient across the inner membrane, termed mitochondrial membrane potential $(\Delta \psi \mathrm{m})$, which is generally used by the ATP synthase (complex V) to drive ATP synthesis. These multienzymatic complexes are known as $N A D H$ dehydrogenase: ubiquinone oxidoreductase (complex I, CI), succinate dehydrogenase (complex II, CII), ubiquinol-cytochrome c oxidoreductase or cytochrome bcl complex (complex III, CIII), and cytochrome c oxidase (complex IV, CIV) (Sharma et al., 2009).

Complex I (CI) is the largest and most complicated component of the respiratory chain. CI couples the transfer of two electrons from NADH to ubiquinone to form ubiquinol with transmembrane proton pumping contributing to the proton motive force used for ATP synthesis (fig. 8). It is considered as the rate-limiting step in overall respiration and plays a central role in energy metabolism (Murphy et al., 1995; Sharma et al., 2009).

Mammalian CI (MW 1 Mega Dalton) is a 45 subunits complex comprising 14 central subunits that execute the core bioenergetics functions and that are conserved from bacteria to humans and 31 accessory subunits (Letts \& Sazanov, 2015). The core subunits are divided into a group of seven hydrophilic and seven hydrophobic polypeptides. The hydrophilic central subunits comprise all redox active prosthetic groups, one flavin mononucleotide (FMN) and eight canonical iron-sulfur clusters (FeS) (Wirth et al., 2016). Activity and assembly regulation of $\mathrm{CI}$ is mediated by phosphorylation of some CI subunits by specific kinases (Papa et al., 2002; Petruzzella \& Papa, 2002). There are a total of 1496 
residues that would be phosphorylated in human CI, Phosphorylation is higher among core subunits and active domains of the complex, among which NDUFS1 displayed significantly higher number as well as percent phospho sites and NDUFA5 contains the least number of potentially phosphorylated residues (Gowthami et al., 2018). Thus, phosphorylation of serine-250 in complex I subunit NdufA10 was needed for ubiquinone reduction by complex I (Morais et al., 2014). The isolated CI produces $\mathrm{O}_{2}{ }^{-}$when FMN is fully reduced depending on NADH/NAD ${ }^{+}$ratio (Kussmaul \& Hirst, 2006; Murphy, 2009).

Mitochondrial complex II or succinate dehydrogenase (SDH) is a central supplier of the reprogramming of metabolic and respiratory adaptation in response to various intrinsic and extrinsic stimuli and abnormalities (Bezawork-Geleta et al., 2017). CII comprises four subunits (SDHA, SDHB, SDHC, and SDHD) encoded by nuclear DNA (nDNA), is a component of the TCA cycle, making a functional link between these two essential processes. Dysfunction of SDH leads to accumulation of succinate, which is categorized as an oncometabolite and signalling molecule (Denko, 2008; E. Kim et al., 2017). It has been shown in isolated mitochondria that high succinate concentrations and high membrane potentials induce reverse electron transfer from complex II into complex I and in consequence a high rate of superoxide production (Lambert \& Brand, 2004).

Mitochondrial complex III or cytochrome $b c l$ complex is an enzyme that catalyses electron transfer from ubiquinol to cytochrome $c$ coupled to translocation of protons across the membrane, hence contributing to the generation of proton motive force used for ATP production. Transfer of electrons within this enzyme, is facilitated by the movement of iron-sulfure protein domain that allows communication between cytochrome $b$ and cytochrome $c 1$ (Borek et al., 2016). Complex III is essential to maintain complex I structural stability and function in mammalian mitochondria while conversely, complex III stability is not influenced by the absence of complex I (Acin-Perez et al., 2004). In Complex III, most of the $\mathrm{O}_{2}{ }^{--}$appears to be formed as a result of the autoxidation of ubisemiquinone, an intermediate produced in Complex III during the Q-cycle, on both the outer and inner sides of the inner mitochondrial membrane (Trumpower, 1990). The presence of inhibitors like antimycin, an inhibitor of Complex III, or for example rotenone, an inhibitor of Complex I, increases the formation of $\mathrm{O}_{2}^{--}$by causing those carriers upstream from the site of inhibition to become fully reduced (Turrens, 2003). 
The oxygen acceptor in the respiratory chain is complex IV. Mitochondrial complex IV or cytochrome c oxidase $(\mathrm{COX})$ is a multi-subunit complex that spans the inner mitochondrial membrane. It is a member of a superfamily of haem-copper oxidases (Rich, 2017). In vertebrates, COX is made up of thirteen subunits and catalyses the last step in respiration, transferring electrons from ferro-cytochrome $c$ to $\mathrm{O}_{2}$ forming $\mathrm{H}_{2} \mathrm{O}$, with proton transfer across the inner membrane (DiMauro et al., 2012; Rak et al., 2016). COX is the only complex with subunits having isoforms identified differently expressed in species, tissues, developmental stages and cellular oxygen concentrations (Kadenbach, 2017). COX could be considered as the pacemaker of electron flow in the mitochondrial respiratory chain of living cells. Its activity is affected by diverse parameters including $\mathrm{pH}$, ionic strength, metal ions, hormones, the inner membrane potential, and the phosphorylation potential [ATP]/[ADP] (Dalmonte et al., 2009; Kadenbach, 2017). A novel regulator of mitochondrial function, Mitochondria Nuclear Retrograde Regulator 1 (MNRR1) binds to COX and induce its full activity. Low MNRR1 levels caused reduction in COX activity, membrane potential, and growth rate, as well as increases in mROS production and mitochondrial fragmentation (Aras et al., 2015).

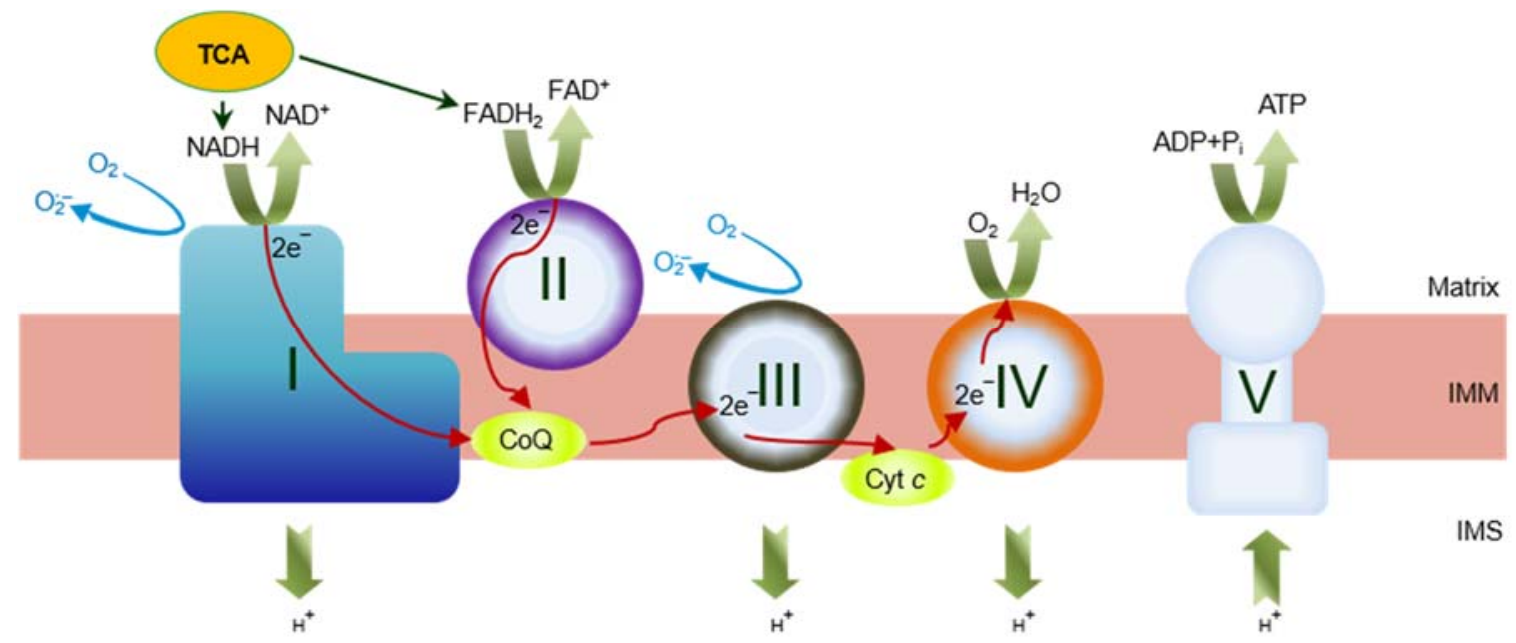

Figure 8. Oxidative phosphorylation and mROS production by the ETC.

Depending on the cellular requirements, the four ETC complexes together with the ATP synthase (CV) physically interact to form a variety of supramolecular structures, called supercomplexes (SCs) or respirasomes, which have been revealed by blue native gel electrophoresis (BNGE) (Schagger \& Pfeiffer, 2000; Schagger \& von Jagow, 1991) and single-particle electron microscopy (Althoff et al., 2011; Dudkina et al., 2011; Lenaz \& 
Genova, 2012). Until a few years ago two major theories were postulated about how respiratory enzymes organize in the inner mitochondrial membrane. While one considers that respiratory enzymes are free floating in the inner mitochondrial membrane (fluid model) (Lapuente-Brun et al., 2013), the other predicts that respiratory enzymes exist in a solid complex composed by different complexes associating with each other (solid model) (Vartak et al., 2013). It has been proposed a plasticity model that would better explain the MRC organization (fig. 9) (Acin-Perez et al., 2008). This model is based on different associations of the individual MRC complexes depending on the cellular requirements. Such associations were named Supercomplexes (SCs).

The current scientific debate is to understand if the functional role of SCs is played in
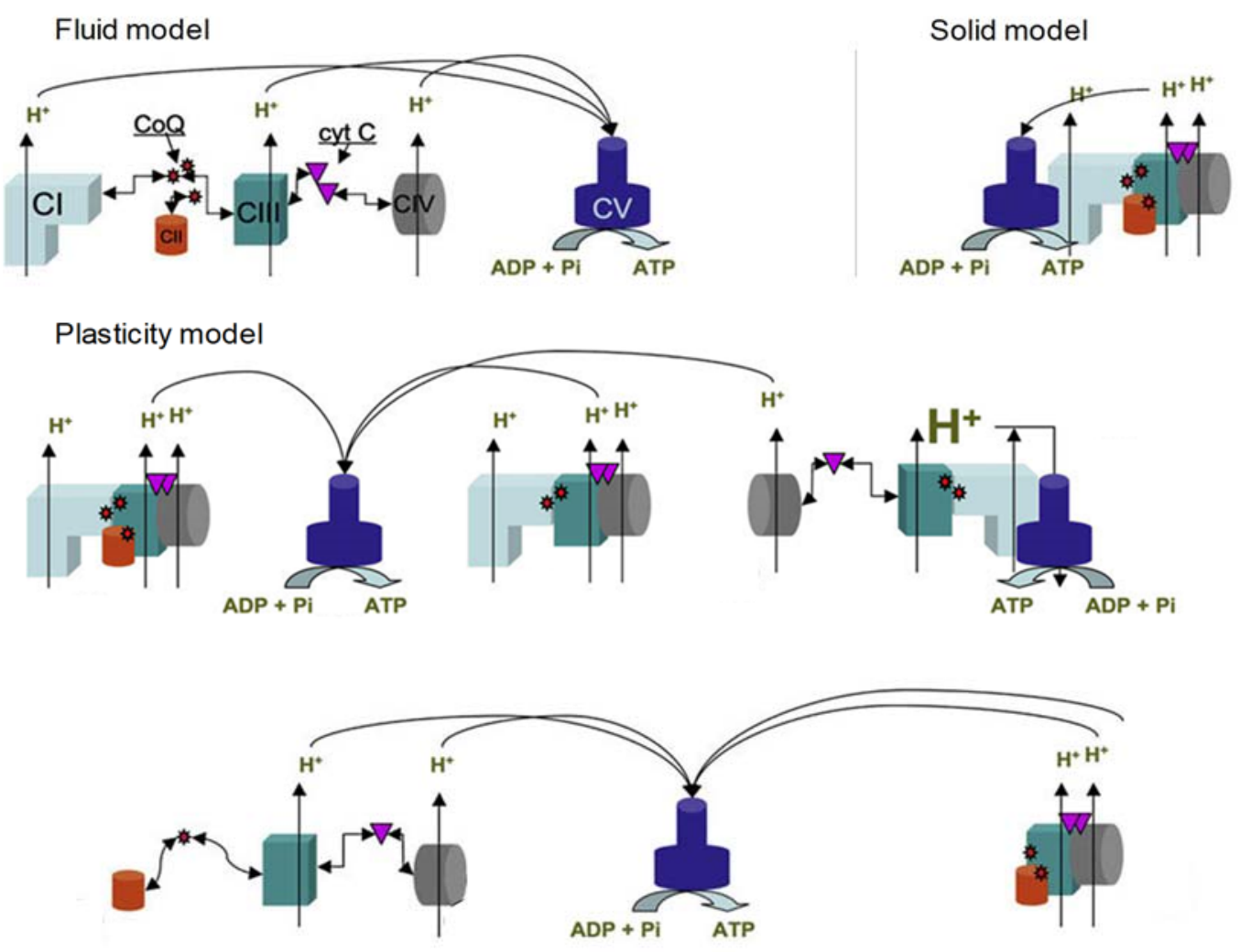

Figure 9. Mitochondrial OxPhos system organization.

cellular bioenergetics, in the formation of reactive intermediates, or in the stabilization of the individual MRC complexes (Lenaz et al., 2016; Lobo-Jarne \& Ugalde, 2017; Milenkovic et al., 2017).

It has been shown that: (i) supercomplex association confers a stability to complexes and (ii) a kinetic advantage by maximizing vicinity between consecutive complexes, and thus facilitating the electron transfer and substrate channelling through partner redox components more efficiently (Acin-Perez et al., 2004; Bianchi et al., 2004; Schagger \& 
Pfeiffer, 2000; Schagger \& von Jagow, 1991), and eventually (iii) reduce the generation of ROS from complex I (Maranzana et al., 2013).

While the most common supercomplexes documented are Complex I/IIIn, Complex I/IIIn/IVn and Complex III/IVn (Cogliati, Calvo, et al., 2016; Dudkina et al., 2011; Letts et al., 2016), small proportion of CII have been associated with I/III/IV (Acin-Perez et al., 2008; Muster et al., 2010). It has been described that the arrangement of complex I and $\mathrm{III}_{2}$ in mitochondrial supercomplexes is widely conserved (Davies et al., 2018).

\subsubsection{Role of mitochondria in apoptosis}

The term apoptosis or programmed cell death is defined as a genetically encoded cell death or cell deletion program (Kerr et al., 1972), which is morphologically, biochemically and molecularly distinct from necrosis. The characteristic morphological signs of apoptosis, cellular shrinkage, membrane blebbing, nuclear condensation and fragmentation, are the final results of a complex biochemical cascade of events which is an integral part of physiological homeostasis (Vermes \& Haanen, 1994). Continuous signalling by growth factors, cytokines, hormones, cell to cell contacts and cell-matrix interactions are necessary for cells to refrain from undergoing apoptosis, keeping them alive (Vermes et al., 2000). These with others, like Phorbol esters, granulocyte macrophage colony stimulating factor or expression of high levels of bcl-2 gene, have been considered as inhibitors of apoptosis (Bright \& Khar, 1994).

There are two major apoptotic pathways: extrinsic and intrinsic (also called the mitochondrial pathway) responding to different signals in vertebrates. Mitochondria play key roles in activating apoptosis in mammalian cells, since it is the origin of signals that initiate the activation of caspases, a family of cysteine proteases that specifically cleave proteins after aspartic acid residues, involving limited proteolysis of a growing number of cellular substrates (Salvesen \& Dixit, 1997). Mitochondria contain several pro-apoptotic molecules that activate cytosolic proteins to execute apoptosis, block anti-apoptotic proteins in the cytosol and directly cleave nuclear DNA. The liberation of the pro-apoptotic molecules into the cytosol seems to be regulated by Bcl-2-like proteins and several ion channels, in particular the permeability transition pore (PTP) that is activated by physiological or stress-induced pro-apoptotic stimuli (Gulbins et al., 2003). Pro-apoptotic proteins released from mitochondria during apoptosis include: (1) cytochrome $c$ (X. Liu et al., 1996; Ugarte-Uribe \& Garcia-Saez, 2017), (2) caspase 9 (P. Li et al., 2017; Susin et al., 
1999), (3) the protein named second mitochondrial activator of caspases (Smac)/direct inhibitor of apoptosis proteins binding protein with low pI (DIABLO) (Du et al., 2000; Verhagen et al., 2000), (4) apoptosis-inducing factor (AIF) (Zamzami et al., 1996), (5) high temperature-requiring proteins (HtrA2) (Suzuki et al., 2001), (6) endonuclease G (L. Y. Li et al., 2001; van Loo et al., 2001).

The involvement of ROS in apoptosis has been widely addressed and it has been evidenced that above a threshold value, increased ROS and NOS production triggers apoptosis (Shen et al., 1998; Sullivan \& Chandel, 2014).

Several pieces of evidence point to oxidative stress as an assumed mediator of apoptosis. It may act by reducing intracellular glutathione, the major buffer of the cellular redox status, and/or by increasing cellular reactive species (Bojes et al., 1997; Suzuki et al., 1998). At low doses, $\mathrm{H}_{2} \mathrm{O}_{2}$ induces apoptosis via production of $\mathrm{OH}$ radicals and alteration of the oxidant/antioxidant pathway (Toledano et al., 1997).

\subsubsection{Mitochondrial morphology}

Mitochondria are highly dynamic organelles (Khacho \& Slack, 2017), continuously shaped by several interacting dynamical phenomena, including fission, fusion, movement, elimination and biogenesis (Aouacheria et al., 2017). The dynamin-related GTPases Optic Atrophy 1 (OPA1) of the inner mitochondrial membrane(Cipolat et al., 2004), and mitofusins (MFN) 1 and 2 of the outer membrane(Santel \& Fuller, 2001), regulate mitochondrial fusion in mammalian cells. Mitochondrial fission is controlled by the cytosolic dynamin related protein DRP1(Smirnova et al., 2001). Mitochondria can shift from small rounded (fragmentend) structures to a more elongated state, and can even develop into filamentous networks (Burte et al., 2015; Cogliati, Enriquez, et al., 2016; Gomes et al., 2011). They can become swollen (Blondin \& Green, 1967; Bonora et al., 2016) or highly fragmented upon apoptosis induction, neurodegeneration and cell division (Bhola \& Letai, 2016; Cherubini \& Gines, 2017; Lopez-Mejia \& Fajas, 2015).

\subsubsection{Mitochondrial transfer between cells}

Recent studies demonstrated that mitochondria can transfer between adjacent cells by a process, termed horizontal transfer (Berridge et al., 2016). Davis and collaborators, reported that neurons in the retinal ganglion zone release and transfer their damaged mitochondria to adjacent astrocytes where they get internalized and degraded (Davis et al., 
2014). Hayakawa and collaborators recently demonstrated that astrocytes can produce functional extracellular mitochondria to support neuronal viability after ischemic stroke (Hayakawa et al., 2016). These authors observed that adding astrocytes-conditioned media containing extracellular mitochondrial particles to rat cortical neuronal cultures, after oxygen-glucose deprivation, increased ATP levels and neuronal viability was recovered. However, the cell viability was lost when extracellular mitochondria were removed from the astrocytes-conditioned media.

\subsubsection{2. mROS production effect on mitochondrial morphology}

To date it is still not clear if the mitochondrial morphology changes upon oxidative stress and whether, in turn, morphology changes may influence mitochondrial production of ROS or impair redox buffer systems. Some evidence suggests that the oxidative stress initiates fission in cerebellar granule neurons, while such fission is prevented by the MFN2 overexpression (Jahani-Asl et al., 2007). Other works also have indicated that the oxidative stress provoke fission upon induction with NO (Barsoum et al., 2006) and 6hydroxydopamine (Gomez-Lazaro et al., 2008). X Liu and G Hajnoczky, suggest a relation between mROS production and donuts-like mitochondrial shaping (X. Liu \& Hajnoczky, 2011). The authors, explain a combined effect between ROS production, mitochondrial $\mathrm{Ca}^{2+}$ sequestration and loss of $\Delta \psi_{\mathrm{m}}$ leading to an activation of the permeability transition pore (PTP), a high conductance channel in the inner mitochondrial membrane. PTP opening converge on water retention and ensuing matrix volume expansion to force partial dissociation of the mitochondria from the microtubules. Partial detachment permits bending of the mitochondria and anomalous fusion that produces donuts shaped mitochondria. As detailed by the authors, hypoxia-reoxygenation stress, induces such a phenomenon.

\subsubsection{Relation between mitochondrial membrane potential $\left(\Delta \psi_{m}\right)$ and mitochondrial morphology}

Some reports establish a consequent relation between $\Delta \psi_{\mathrm{m}}$ and mitochondrial shaping. Galloway et al. demonstrate that perturbation of mitochondrial fission induces mitochondrial uncoupling through a large-scale fluctuation of $\Delta \psi_{\mathrm{m}}$ (Galloway et al., 2012). Recently, Miyazono and collaborators (Miyazono et al., 2018) evaluated the early period of structural changes during the $\Delta \psi \mathrm{m}$ loss-induced transformation after carbonyl cyanide $m$ chlorophenyl hydrazine (CCCP) administration (in MEFs and HeLa cells). They found that 
most mitochondria changed from a tubular shape to a globular shape without any detectable fusion or fission and most structural changes were initiated within tens of seconds after CCCP administration and the transformation to the new shape lasted few minutes.

\subsubsection{Mitochondrial morphology in hypoxia}

Apart of the mitochondrial morphology alteration, induced in situation of hypoxiareoxygenation stress (X. Liu \& Hajnoczky, 2011), Kim and collaborators, demonstrate a fission event of mitochondrial membranes at reduced oxygen levels under hypoxic conditions dependent on availability of the mitochondrial scaffolding protein AKAP121 (A-kinase anchoring protein 121) located at the mitochondrial membrane (H. Kim et al., 2011). They showed that mitochondria of NIH 3 T3 mouse fibroblast cells, maintained for 24 hours under hypoxia were less elongated and more fragmented suggesting that hypoxia induces mitochondria remodelling (fig. 10).
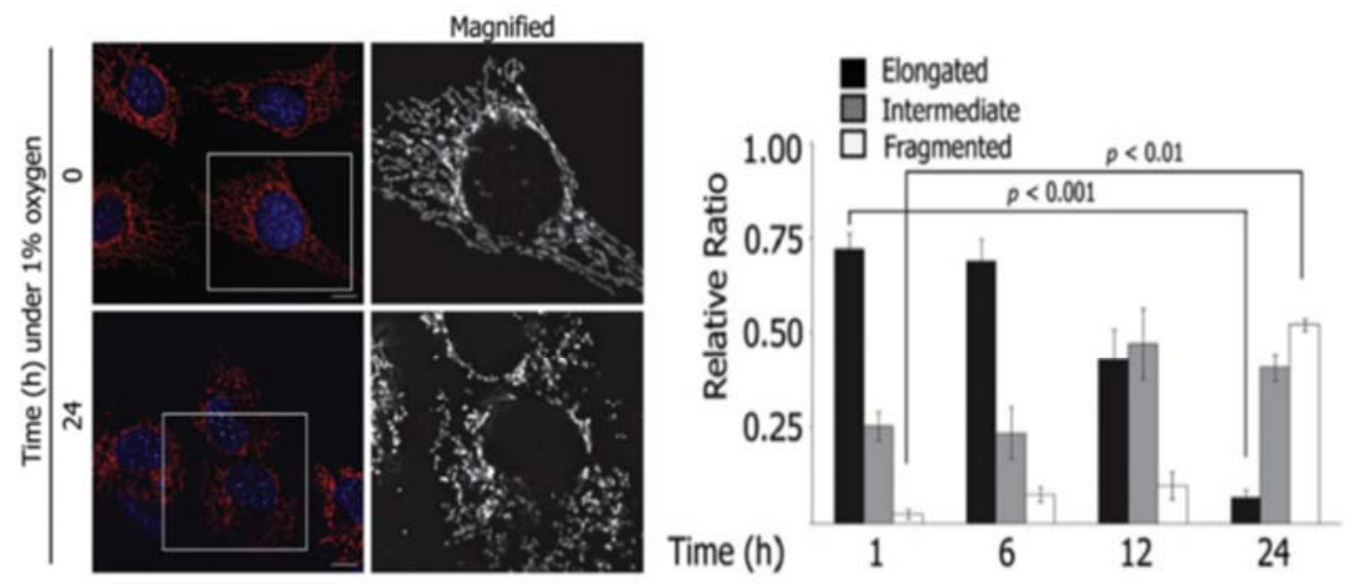

Figure 10. Hypoxia induced fission. Kim et al., (2011).

\subsection{Brain energy metabolism}

\subsubsection{Glucose metabolism}

Glucose is the first energy substrate of the adult brain. Notwithstanding, under particular circumstances the brain has the ability to use other blood-derived energy substrates, such as ketone bodies during development and starvation (Nehlig, 1999, 2004) or lactate during periods of intense physical activity (Pellerin, 2010; van Hall et al., 2009). Glucose enters 
the neuronal cells through specific glucose transporters that in brain are GLUTs ( 1 to 6,8 and 10), SGLTs (3, 4 and 6), and HMIT (H+-driven myoinositol/glucose co-transporter, also called GLUT13) (Mueckler \& Thorens, 2013; Wright, 2013). Due to the restrictive permeability of the BBB and the relative lack of local brain carbohydrate stores (glycogen, mostly in astrocytes), the CNS relies heavily upon BBB expression of transporters for the delivery of key nutrients and solutes to the brain. Glucose is then phosphorylated by hexokinase (HK) to produce glucose-6-phosphate (glucose-6P). Glucose-6P can be processed through different metabolic pathways (fig. 11), resumed as: (i) the glycolysis, leading to lactate production or mitochondrial metabolism via pyruvate use, (ii) the pentose phosphate pathway (PPP), (iii) the glycogenesis and (iv) oligosaccharide synthesis for glycoproteins and glycolipids. Although, glucose is admitted to be almost entirely oxidized to $\mathrm{CO}_{2}$ and water in the brain, (Clarke \& Sokoloff, 1999) the existence of different metabolic routes for glucose within the cell indicates that the ultimate fate of glucose is not necessarily getting metabolized to $\mathrm{CO}_{2}$ and water. Indeed, a wide range of metabolic intermediates formed from glucose in the brain can afterwards be oxidized for energy production (e.g., lactate, pyruvate, glutamate, or acetate) (Zielke et al., 2009).

\subsubsection{Glycolysis}

Neurons and astrocytes, are responsible of mayor brain consumption of $\mathrm{O}_{2}$ and glucose. They exhibit a different preference for glucose utilization. Under resting conditions, astrocytes release $85 \%$ of consumed glucose as lactate (Bolanos et al., 1994), while neurons, show minor glucose consumption (Almeida et al., 2004) and glycolysis due basically to the constant degradation by E3 ubiquitin ligase anaphase-promoting complex/cyclosome (APC/C)-CDH1 of the glycolysis promoting enzyme 6-phosphofructo-2-kinase/fructose 2,6-bisphosphatase, isoform 3 (PFKFB3) (fig. 11) (Bolanos, 2016; Bolanos et al., 2010; Herrero-Mendez et al., 2009). Following inhibition of respiration, astrocytes undergo a rapid, cGMP-independent increase in the activity of 6-phosphofructo-1-kinase (PFK1), a master regulator of glycolysis (Almeida et al., 2004) with a significant increase of fructose2,6-bisphosphate (F2,6P2), an allosteric activator of PFK1, that shows no increase in this condition in neurons (Bolanos et al., 2010). In astrocytes, inhibition of respiration using NO shows an increase of phosphorylation of the enzyme 5-AMP-activated protein kinase (AMPK) coincident with the accumulation of F2,6P2, and activation of PFKFB (Almeida et al., 2004; Bolanos et al., 2010). 


\subsubsection{Pentose Phosphate Pathway (PPP)}

PPP converts glucose-6-phosphate (G6P) into ribulose-5-phosphate (R5P) (fig. 11) conserving its redox potential in the form of NADPH (which is required for the fatty acid synthesis and the generation of reduced GSH, a major scavenger of ROS); thus, by two sequential reactions, catalyzed by glucose-6-phosphate dehydrogenase (G6PD) and 6phosphogluconate dehydrogenase (6PGD), 2 mol of NADPH are generated from 2 mol of NADP+ per mol of G6P oxidized (Wamelink et al., 2008). In neurons, our group has observed that G6PD is rapidly activated by peroxynitrite anion (ONOO$\left.{ }^{-}\right)$through an indirect mechanism that upregulates the PPP activity and enhances the ability of neurons to regenerate GSH from GSSG (Garcia-Nogales et al., 2003). Thus, the antioxidant fragility of neurons conferred by low GSH abundance is compensated by a high PPP to increase the rate at which GSH is regenerated from GSSG (Bolanos, 2016).

\subsubsection{Glycogen brain store}

Despite the low level of glycogen in the CNS compared to peripheral tissues, it is still the largest energy reserve of the adult mammalian brain. It is in particularly activated in metabolic stress conditions like hypoglycemia (Rehni \& Dave, 2018). It has become dogma that astrocytes are the only nervous cells where glucose-6P can be used to store glucosyl units as glycogen. (Brown, 2004; Brown et al., 2003; Oe et al., 2016; Wiesinger et al., 1997), even though it was reported that neurons contain a low but measurable amount of glycogen and express the brain isoform of glycogen phosphorylase, allowing glycogen to be fully metabolized (Saez et al., 2014).

\subsubsection{Neuron-astrocytes coupling}

While astrocytes constitute the major reservoir of energy in the CNS in the form of glycogen, they would respond rapidly to a drop in energetic fuel and subsequently liberate lactate as a substituent of glucose to the cell functioning at periods of intense physical activity (van Hall et al., 2009). The big theory of the last decades concerning the use of this lactate liberated from astrocytes by neurons in a model referred to as the 'Astrocyte-Neuron Lactate Shuttle' (ANLS) (fig. 11) was polemically criticised by a number of scientists believing the shuttle is working on a reverse scheme and that neurons were the providers of lactate. The latter stills struggling with a lack of evidence advanced to prove the controversy while the ANLS evidence pointed at a major contribution of astrocytes to neuro-energetics (Magistretti et al., 1981; Pellerin \& Magistretti, 1994). The 
morphological and phenotypical characteristics of astrocytes ideally position them to sense neuronal activity at the synapse and respond with the appropriate metabolic supply via their astrocytic endfeet (see section 1.1.3). The ANLS is explained by the authors because of the difficulty of lactate to cross the blood-brain barrier (Pellerin et al., 1998). The authors, on one hand, demonstrated the presence of mRNA for monocarboxylate transporters MCT1 and MCT2 in adult mouse brain. On the other hand, by using monoclonal antibodies selectively directed against the two distinct lactate dehydrogenase isoforms, LDH1 and LDH5, demonstrated a specific cellular distribution between neurons and astrocytes, suggesting that a population of astrocytes is a lactate 'source' while neurons may be a lactate 'sink'. Neuronal activity leads to a localized increase in glucose utilization. In this, scheme, lactate produced by astrocytes, is used as a substrate for oxidative metabolism in neurons.

Astrocytes do not perform a passive linear readout of the synaptic activity but they better integrate and process synaptic information elaborating a complex nonlinear response to the incoming input signals from adjacent synapses, thus they control synaptic transmission and plasticity showing an active participation to the 'tripartite synapse' (Parpura et al., 1994; Perea et al., 2009; Perez-Alvarez \& Araque, 2013). As for glutamatergic neurotransmission, where Glutamate constitutes the major excitatory neurotransmitter, responsible for many of the brain's functions including cognition and memory (Curtis et al., 1960; Maksymetz et al., 2017; Sheldon \& Robinson, 2007), astrocytes take up neuronal-released glutamate from the synaptic cleft through secondary, $\mathrm{Na}+$-dependent active glutamate transporters (Glu-T; fig. 11). The $\mathrm{Na}+$ used for the glutamate uptake is restored by the $\mathrm{Na}+/ \mathrm{K}+$-ATPase pump in order to keep the $\mathrm{Na}+$ gradient. The energy needed for $\mathrm{Na}+/ \mathrm{K}+-\mathrm{ATPase}$ during high activities would be potentially assured by the increase of glycolytic rate combined to a higher ANLS activity (Bolanos, 2016). 


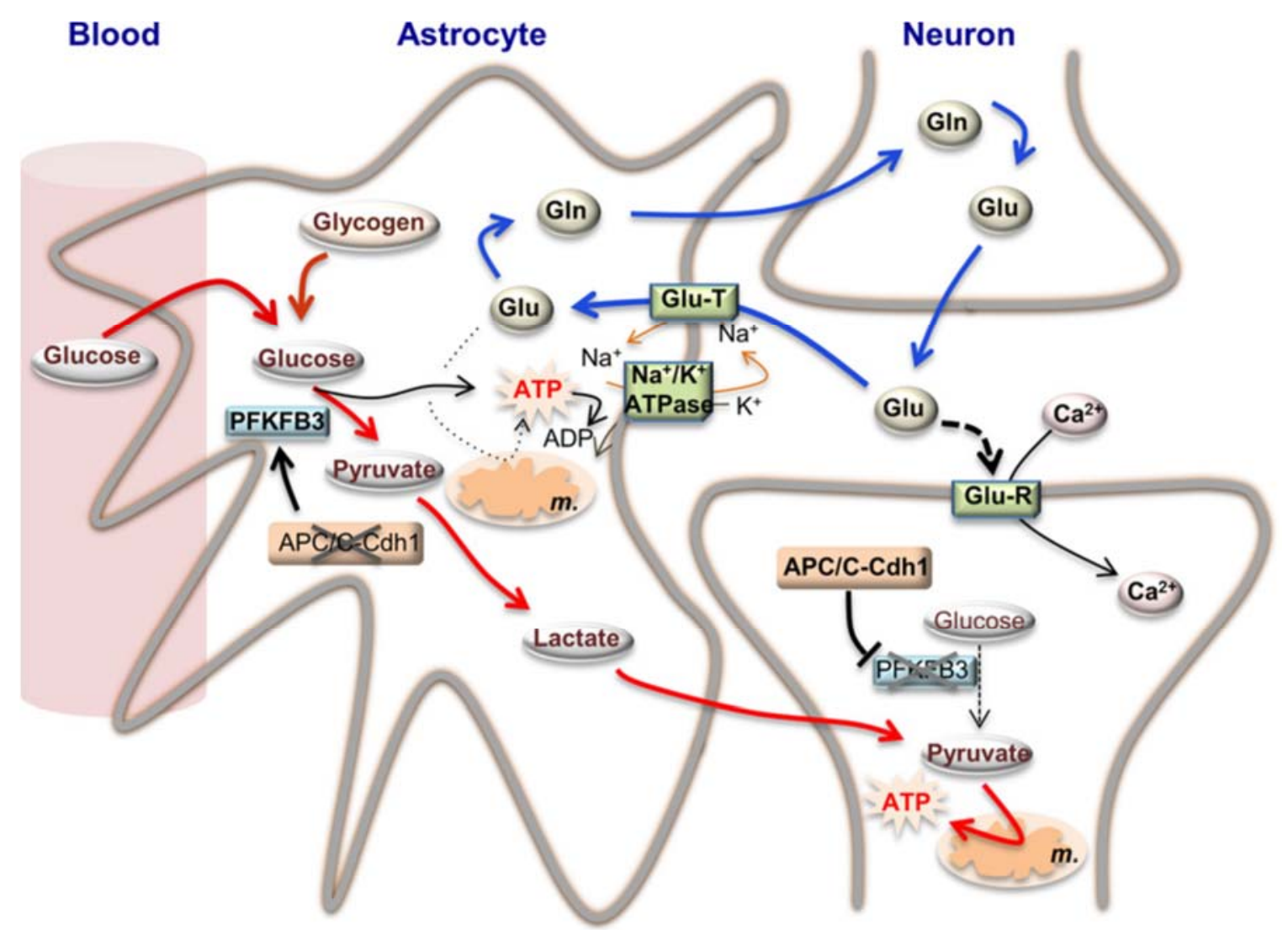

Figure 11. Bioenergetics adaptations of astrocytes to neurotransmission in a tripartite synapse. Bolanos, (2016).

\subsection{Oxidative stress}

\subsubsection{Reactive Oxygen Species (ROS)}

Almost all eukaryotic cells rely on molecular oxygen $\left(\mathrm{O}_{2}\right)$ to derive energy from nutrients. The poisonous properties of oxygen were unknown prior to the publication of Gershman's free radical theory of oxygen toxicity in 1954, where he states that the toxicity of oxygen is due to partially reduced forms of oxygen (Gerschman et al., 1954). In the same year, Commoner (Commoner, 1954) reported novel observations of an electron paramagnetic resonance (EPR) signal due to the presence of free radicals in a variety of lyophilised biological materials.

Reactive oxygen species (ROS) are free radicals, oxygen by-products that contain one or more unpaired electrons in their outermost shell and are generated from molecular oxygen by different chemical reactions (fig. 12). ROS includes the superoxide anion $\left(\mathrm{O}_{2}{ }^{--}\right)$, hydrogen peroxide $\left(\mathrm{H}_{2} \mathrm{O}_{2}\right)$ and the hydroxyl radical $\left(\mathrm{HO}^{*}\right)$. One-electron reduction of $\mathrm{O}_{2}$ generates $\mathrm{O}_{2}{ }^{--}$. Dismutation of $\mathrm{O}_{2}^{--}$by the superoxide dismutase enzyme or by 
spontaneous dismutation produces $\mathrm{H}_{2} \mathrm{O}_{2}$ (Baehner et al., 1975; Kanzaki et al., 2017) (fig. 12) what can be subsequently converted into $\mathrm{H}_{2} \mathrm{O}$ via catalases.

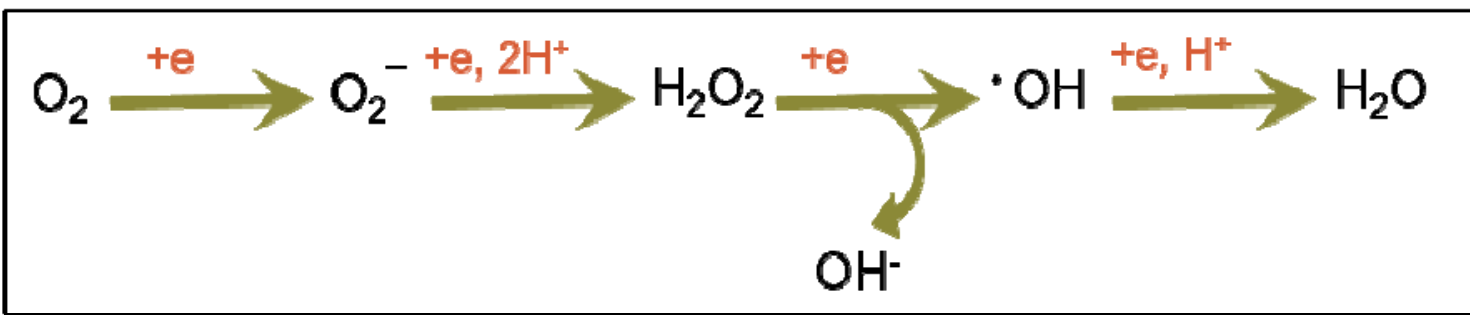

Fig. 12. Electrons and protons capture by $\mathrm{O}_{2}$.

The toxicity of these species may be influenced by the proximity of superoxide and hydrogen peroxide, which participate to the Haber Weiss reaction $\left(\mathrm{O}_{2}{ }^{-}+\mathrm{H}_{2} \mathrm{O}_{2} \rightarrow \mathrm{HO}^{\circ}+\mathrm{O}_{2}{ }^{-}{ }^{-} \mathrm{OH}\right)$ or of metal ions via the Fenton reaction $\left(\mathrm{H}_{2} \mathrm{O}_{2}+\mathrm{Fe}^{2+} \rightarrow \mathrm{HO}^{\circ}+\mathrm{Fe}^{3+}+{ }^{-} \mathrm{OH}\right)$ (fig. 13), resulting in a more toxic oxygen species, the hydroxyl radical ( $\mathrm{HO}^{\circ}$ ) (Staerck et al., 2017). It is commonly accepted that most of $\mathrm{O}_{2}{ }^{-{ }^{-}}$is produced as a consequence of an electron leak from ETC complexes I, II, and III (Jastroch et al., 2010; Muller et al., 2004; Turrens, 2003).

ROS operate contentedly as intracellular signalling molecules, a function that has been widely documented but is still controversial (D'Autreaux \& Toledano, 2007; Scialo et al., 2017) they have been shown also to modulate the differentiation of neurons in clonal cortical cultures (Tsatmali et al., 2006).

ROS are important elements in maintaining normal homeostasis as inter and intracellular signal molecules, both in physiological as in pathophysiological conditions. However, ROS remain highly reactive molecules and can damage various cellular components when produced massively (Yarjanli et al., 2017), like nucleic acids in DNA (Czarny et al., 2017) or RNA, amino acids in proteins and fatty acids in the cell membrane etc. Because of their high reactivity, their half-life is very short (Gielis et al., 2017). In a basal physiological state, a redox homeostasis is assured by the equilibrium between oxidants and antioxidants (Dharmaraja, 2017). When the rate of ROS formation overtakes the capacity of antioxidant systems to detoxify them, it creates what is called "oxidative stress" (Marrocco et al., 2017; Signorini et al., 2017). This is a common denominator in the pathogenesis of many chronic diseases like rheumatoid arthritis (RA), Alzheimer's disease (AD), Parkinson's disease (PD), amyotrophic lateral sclerosis (ALS), cardiovascular disease, allergies, immune system dysfunctions, diabetes etc. (Ahmadinejad et al., 2017; Imam et al., 2017). 


\subsubsection{Antioxidant systems}

In response to excess ROS production, eukaryotic cells have evolved numerous antioxidant systems including free radical scavengers and enzymes (fig. 14). The enzymatic group include a number of enzymes such as catalase, the enzymes of both glutathione and thioredoxin systems (Jimenez-Blasco et al., 2015) and superoxide dismutase (SOD) (Ahmadinejad et al., 2017). SOD exists in three major cellular forms: copper zinc $(\mathrm{Cu} / \mathrm{ZnSOD}$, SOD1), manganese (MnSOD, SOD2), and extracellular (SOD3). These enzymes detoxify superoxide radicals to hydrogen peroxide $\left(\mathrm{H}_{2} \mathrm{O}_{2}\right)$ and oxygen (Al-Kafaji et al., 2015). At the matrix SOD2 assures the dismutation of $\mathrm{O}_{2}{ }^{-}$to $\mathrm{H}_{2} \mathrm{O}_{2}$ (Fridovich, 1997), while the intermembrane space requires diffusion via a voltage-dependent anion channels into the cytosol (Han et al., 2003), where it is converted to $\mathrm{H}_{2} \mathrm{O}_{2}$ by SOD1. Catalases exist in eukaryotic peroxisomes and catalyse the conversion of $\mathrm{H}_{2} \mathrm{O}_{2}$ into water and oxygen in the presence of iron or manganese cofactors (Chelikani et al., 2004).

\subsubsection{The glutathione system}

The glutathione system comprises three enzymes, glutathione reductase (GR), glutathione peroxidases (GPx) and glutathione S-transferases (GST), that contribute in breakdown of $\mathrm{H}_{2} \mathrm{O}_{2}$ and hydroperoxides using selenium as the cofactor (Lemire et al., 2017). Glutathione tripeptide (GSH, $\gamma$-L-glutamyl-L-cysteinylglycine) is regenerated by glutathione reductase (GR), the reducing equivalents being derived from nicotinamide adenine dinucleotide phosphate (NADPH). GSH has essential cellular functions in many detoxification processes. In addition, to its chemical reaction with radicals and electrophiles, GSH serves as substrate or cofactor of a large number of detoxifying cellular enzymes (Deponte, 2013). The high cellular GSH content and the strong capacity of astrocytes for GSH-dependent detoxification processes helps to protect these cells and their neighbours, in particular neurons, against the toxic potential of oxidants and toxins (Barker et al., 1996). Astrocytes, supply essential precursors for GSH synthesis to neighbouring neurons, and increases its level in co-culture (Dringen et al., 1999). GSH is synthesized in astrocytes, as in neurons, by 2 ATP-consuming cytosolic enzymes. In the first reaction, considered as rate limiting in cellular GSH synthesis, glutamate cysteine ligase (GCL) catalyses the formation of the dipeptide $\gamma$ glutamylcysteine ( $\gamma$-GluCys), from the amino acids glutamate and cysteine (fig. 13). The second reaction is catalysed by GSH synthetase (GSH-Syn) which adds glycine in an ATP-driven reaction to $\gamma$-GluCys to generate the tripeptide GSH. 


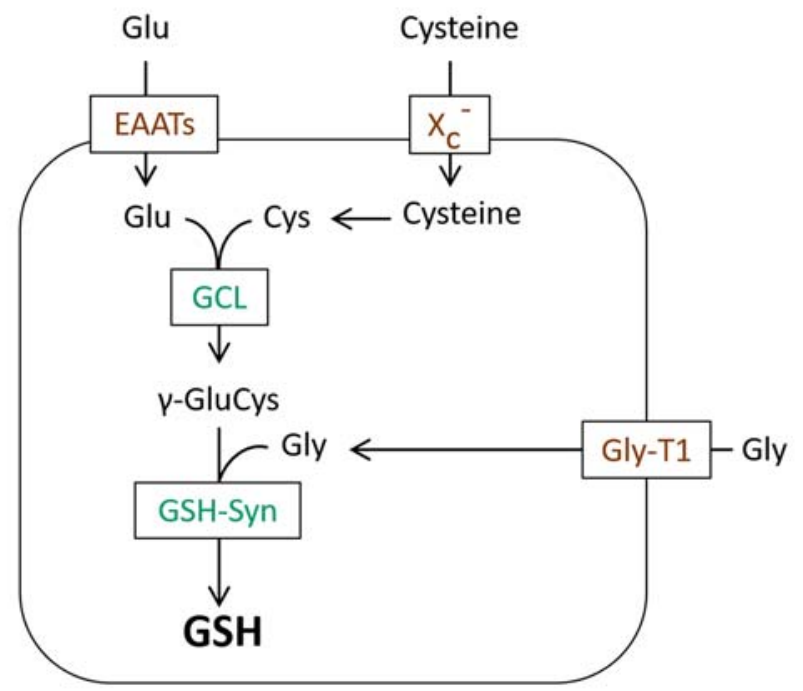

Figure 13. GSH synthesis. GSH substrates (glutamate and glycine) are taken up into astrocytes and neurons, by the excitatory amino acid transporters (EAATs) 1 or 2 and by glycine transporter GlyT1. Cysteine is taken up into astrocytes by the cystine-glutamate antiporter $X_{C^{-}}$. Adapted with minor correction from Dringen et al., (2015).

\subsubsection{The thioredoxin system}

The thioredoxin system contains NADPH, peroxiredoxin (Hall et al., 2011), thioredoxin (Trx) protein and thioredoxin reductase (TrxR) and acts as a scavenging factor for ROS (fig. 14). This highly conserved system is ubiquitous and present in all levels of life - from plants to archaea and humans - and plays a pivotal role in maintaining a reduced intracellular environment (Ahmadinejad et al., 2017).

The non-enzymatic group contains a number of antioxidants that act directly on oxidative agents and are acquired from dietary sources. This group includes vitamin C (Ascorbate), vitamin E (tocopherol), carotenoids, flavonoids, polyphenols etc. (Halliwell, 1994; Khazaei \& Aghaz, 2017; Nagoor Meeran et al., 2017; Tatar et al., 2017). 


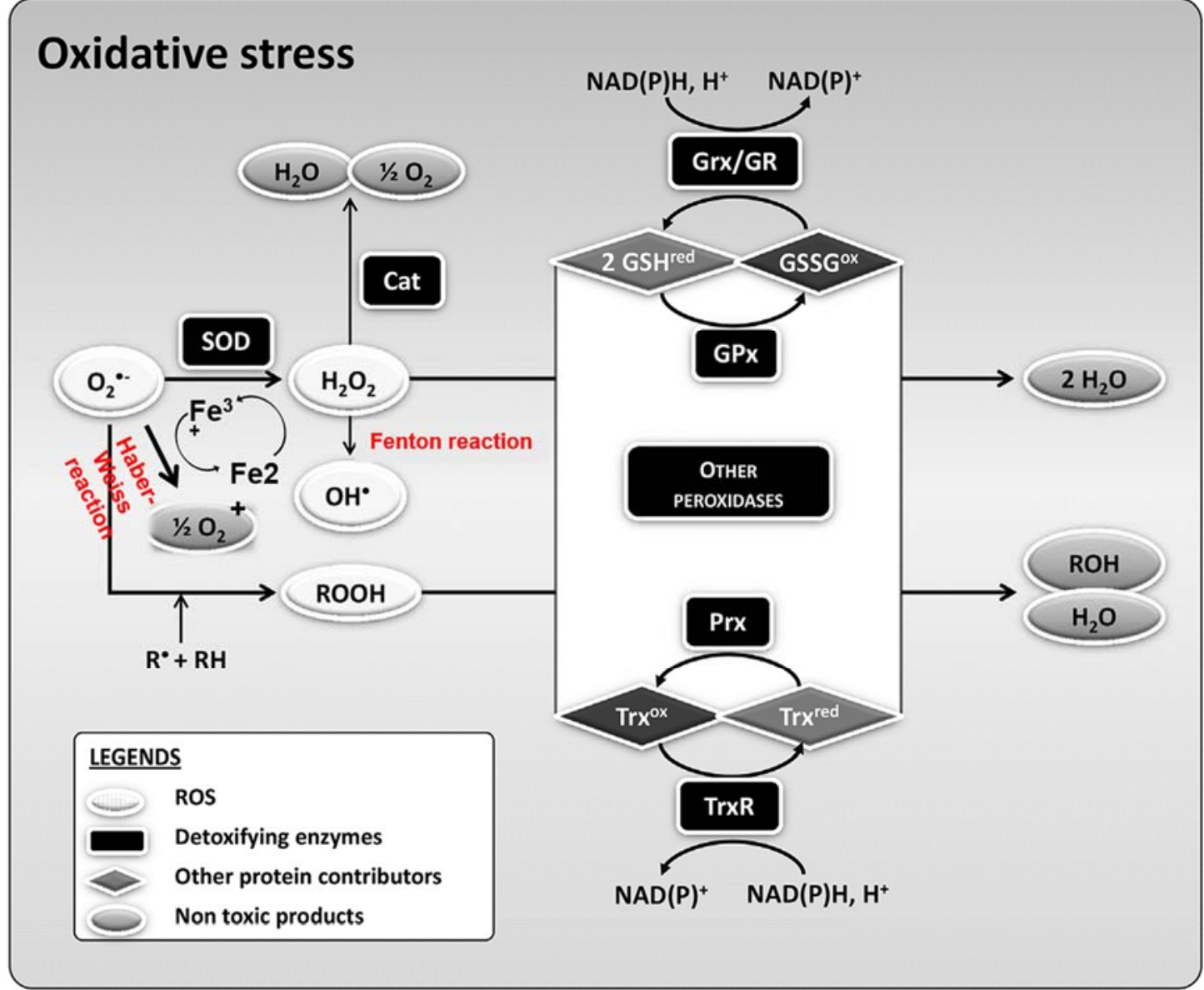

Figure 14. Main cellular ROS production and detoxifying mechanisms. Adapted from Staerck et al., (2017) 


\section{2- Hypothesis and objectives}

Our current knowledge on neuronal metabolism and its regulation are mainly derived from experimental culture conditions that do not fully resemble the physiological situation. Amongst the main drawbacks, we highlight (i) the absence of neighbour astrocytes in close interaction with neurons, and (ii) the occurrence of atmospheric (21\%) $\mathrm{O}_{2}$ tension, suggesting that these factors may strongly impact on neuronal oxidative metabolism (Bolanos, 2016). Regarding oxygen tensions, it has been estimated that neural cells in vivo are exposed to $\mathrm{O}_{2}$ concentrations ranging from 1 to $10 \%$, depending on the distance from the brain vessels (Devor et al., 2011).

Accordingly, we plan to develop the following objectives:

(i) To characterize the neuronal and astrocytic phenotype at different $\mathrm{pO}_{2}$ in order to define physiological and pathological-like $\mathrm{pO}_{2}$ in culture.

(ii) To evaluate the energy metabolism under physiological $\mathrm{pO}_{2}$.

(iii) To ascertain the effect of astrocytes in co-culture with neurons energy and redox metabolism.

(iv) To investigate the mitochondrial shape at very low and at physiological $\mathrm{pO}_{2}$. 


\section{3- Material and methods}

\subsection{Animals}

C57BL/6J mice were supplied by the Animal Experimentation Service of the University of Salamanca. Bredding was in cages with a 12 hours' light-dark cycle, $45 \%$ to $60 \%$ of humidity and $20^{\circ} \mathrm{C}$ to $25^{\circ} \mathrm{C}$ of room temperature. Animals were fed ad libitum with a standard solid diet (17\% proteins, $3 \%$ lipids, $58.7 \%$ glucidic component, $4.3 \%$ cellulose, $5 \%$ minerals and $12 \%$ humidity) and with free access to water.

Gestational stage was controlled by limiting the cohabitation of virgin mice with males to one night. At 9:00 a.m. of the following day, mice that had the presence of spermatozoids in the vaginal smear accompanied by epithelial cells from the vagina (characteristic of a fertile day of the estrus) were isolated. Under these conditions, gestational period of the mouse is assumed to be 19 days.

All animal handlings and procedures are in agreement with the current regulation from the European commission (2014/11/EU) and Spanish legislation (Law 6/2013) related to accommodation and experimental animals care. All the protocols performed in this Thesis were approved by Bioethics Committee of the University of Salamanca.

\subsection{Cell culture}

\subsubsection{Cortical neurons in primary culture}

Cortical neurons in primary culture were prepared from 14 days (E14) murine foetuses according to standard procedure (Almeida \& Medina, 1998). In brief, pregnant mice were sacrificed in a $\mathrm{CO} 2$ atmosphere followed by cervical dislocation and the embryos were removed by hysterectomy. In a laminar flux cabin (TC48, Gelaire Flow Laboratories, McLean, Virginia, USA) brains were removed and hemispheres were separated and cut into small fragments with a scalpel, in Earle's Balanced Salt Solution (EBSS; $116 \mathrm{mM}$ $\mathrm{NaCl}, 5.4 \mathrm{mM} \mathrm{KCl}, 1.01 \mathrm{mM} \mathrm{NaH}_{2} \mathrm{PO}_{4}, 1.5 \mathrm{mM} \mathrm{MgSO}_{4}, 26 \mathrm{mM} \mathrm{NaHCO}_{3}, 4 \mathrm{mM}$ glucose, $10 \mathrm{mg} / \mathrm{mL}$ phenol red, 0,3 \% w/v albumin and $20 \mu \mathrm{g} / \mathrm{mL}$ DNAse type I; $\mathrm{pH}$ 7.2).

Minced brains were disintegrated in trypsinization solution EBSS supplemented with trypsin, $0.025 \% \mathrm{w} / \mathrm{v}$ ) for 15 minutes, at $37^{\circ} \mathrm{C}$ in a thermostatic bath. Trypsinization was ended by adding fetal calf serum (FCS; Roche Diagnostics, Heidelberg, Germany) to a final concentration of $10 \%, \mathrm{v} / \mathrm{v}$. Cell suspension was centrifuged at $500 \mathrm{x}$ g during 5 minutes 
(Eppendorf, Centrifuge 5702, Hamburg, Germany) and the cellular pellet was re-suspended in $12 \mathrm{~mL}$ of disintegration solution and disaggregated with 9 passes through a fire-polished and siliconated Pasteur pipette. After 4 minutes of sedimentation, the supernatant containing the dissociated cells was carefully removed and placed in a fresh $50 \mathrm{~mL}$ tube. This process was repeated once more in order to increase the cellular yield. The supernatants were then centrifuged at $500 \mathrm{x}$ g for 5 minutes. The cellular sediment was resuspended, in $10 \mathrm{~mL}$ of Neurobasal ${ }^{\circledR}$-A medium (ThermoFisher Scientific) supplemented with $5.5 \mathrm{mM}$ of glucose, $2 \mathrm{mM}$ of glutamine and 2\% B-27® supplement (Life Technologies, USA). $10 \mu \mathrm{L}$ of the cellular suspension was used for cell counting in presence of $0.4 \%$ trypan blue (Sigma-Aldrich) using a Neubauer chamber (Zeiss, Oberkochen, Germany) and a phase contrast microscope (CK30 model, Olympus, Japan). The cell suspension was diluted with culture medium at $1 \times 10^{6}$ cells $/ \mathrm{mL}$ and seeded at $2.0-2.5 \times 10^{5}$ cells $/ \mathrm{cm}^{2}$ in plastic culture plates (Nunc; Roskilde, Denmark \& Costar ${ }^{\circledR}$; Corning® for co-culture), previously coated with Poly-D-Lysine (PDL) $(10 \mu \mathrm{g} / \mathrm{mL}$; Sigma- Aldrich). Cultures were incubated either in air (at $21 \%$ of $\mathrm{O}^{2}$ ), in a thermostatized cell-culture incubator (Thermo Forma 310, Thermo-Fisher Scientific, Ohio, USA), or at lower $\mathrm{O}_{2}$ concentrations ( $2 \%$ to $6 \%$ of $\mathrm{O}_{2}$ ) in a hypoxia incubator chamber (Ruskinn ${ }^{\mathrm{TM}}$ Invivo2 400 Hypoxia Workstation; Baker company, UK), able to maintain specific and stable low oxygen concentrations for long periods of time. Incubations were at $37^{\circ} \mathrm{C}$ and $5 \% \mathrm{CO}_{2}$ in both cases. After 3 days in vitro (3 DIV), medium was removed and replaced by Neurobasal ${ }^{\circledR}$-A (Thermo-Fisher Scientific) supplemented with $5.5 \mathrm{mM}$ of glucose, $2 \mathrm{mM}$ of glutamine and $2 \% \mathrm{~B}-27{ }^{\circledR}$ Minus antioxidants (MAO) (in absence of: vitamin E, vitamin E acetate, superoxide dismutase, catalase, and glutathione) (Life technologies, USA). Cells were used for the experiments at 6-7 DIV. Under these conditions, at the time of experiments, neuronal cultures showed 97-99\% purity as assessed by immunoreaction with the neuronal marker Map-2 (Almeida et al., 2005).

\subsubsection{Astrocytes in primary culture}

Astrocytes in primary culture were obtained from mice pups from 0 to 24 hours of age (Almeida \& Medina, 1998). Animals were decapitated and the whole brain was removed under aseptic conditions in a laminar flux cabin. Cerebellum and olfactory bulb were removed using forceps and the cerebral hemispheres, once cleaned from meninges and blood vessels, were placed in EBSS and minced into small fragments. Cellular suspension was obtained as previously described for neurons. Cellular suspension was seeded in 175 
$\mathrm{cm}^{2}$ culture flasks (BD, Falcon), at 250,000 cells/cm2 in DMEM supplemented with $10 \%$, $\mathrm{v} / \mathrm{v}, \mathrm{FCS}$. Cells were incubated in a thermostatic cell-culture incubator at $37^{\circ} \mathrm{C}$ and $5 \%$ $\mathrm{CO}_{2}$, with two media changes per week. At day 7, flasks were shaken at $180 \mathrm{rpm}$ for 16 hours in an orbital shaker, under the same culture conditions. Medium with floating cells was discarded and the astrocytes-enriched cells monolayer was harvested by trypsinization for $4 \mathrm{~min}$. The reaction was stopped by adding foetal calf serum (FCS; Roche Diagnostics, Heidelberg, Germany) at a final concentration of $10 \%$, v/v, and cell suspension was centrifuged at $500 \mathrm{x}$ g during 5 minutes (Beckman Instruments, Palo Alto, California, USA). Cells were re-suspended in $10 \mathrm{~mL}$ of Neurobasal ${ }^{\circledR}$-A supplemented with $5.5 \mathrm{mM}$ of glucose, $2 \mathrm{mM}$ of glutamine and 2\% B-27® and counted by a Neubauer chamber in a phase contrast microscope, as before. The cell suspension was then seeded at $100.000 \mathrm{cells} / \mathrm{cm}^{2}$ in plastic culture plates (BD, Falcon) or in differently sized Transwell-clear Inserts with a polyester membrane for the co-cultures (Transwell ${ }^{\circledR}$, Corning ${ }^{\circledR}$, Life Science, Massachusetts, USA). When astrocytes were seeded on culture plates, medium was replaced every 3 days and were used after 6-7 additional days in culture. Culture of astrocytes on polyester inserts for co-cultures is described in the next section.

\subsubsection{Co-culture}

Neurons-Astrocytes co-cultures were performed as previously described (Jimenez-Blasco et al., 2015) with minor modifications. At day 3 of the neuronal culture, inserts of appropriated sizes containing astrocytes were placed into the plates containing neurons (see fig. 15) and the media of both receptacles was replaced by Neurobasal ${ }^{\circledR}$ MAO. Cells were incubated for three additional days at $21 \% \mathrm{O} 2$, or $2 \%$ to $6 \% \mathrm{O} 2$, in the corresponding incubators before performing the analyses.

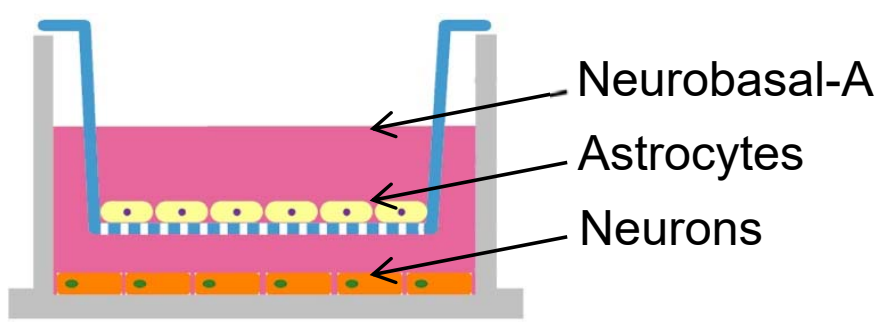

Figure 15. Co-culture system. 


\subsection{Equilibrated media for lower $\mathrm{pO}_{2}$}

For culturing cells at oxygen lower concentrations than atmospheric, it was necessary to equilibrate the media at the low $\mathrm{pO}_{2}$ existing in the incubator. In order to calculate the time necessary to reach the equilibrium, media were stirred (Gilson LabStir ${ }^{\mathrm{TM}}$ ) in a beaker or open flask inside incubator and media $\mathrm{pO}_{2}$ were monitored vs. time using a Crison ${ }^{\mathrm{TM}} \mathrm{OXI}$ 45 oxymeter $\left(\right.$ Hach ${ }^{\circledR}$, Barcelona, Spain). As it is observed in fig. 16 the minimum time required to stabilize the oxygen concentration in media, in an atmosphere with $2 \% \mathrm{pO}_{2}$ was of 10 min. All media used in experiments with lower oxygen than atmospheric were equilibrated during at least $15 \mathrm{~min}$.

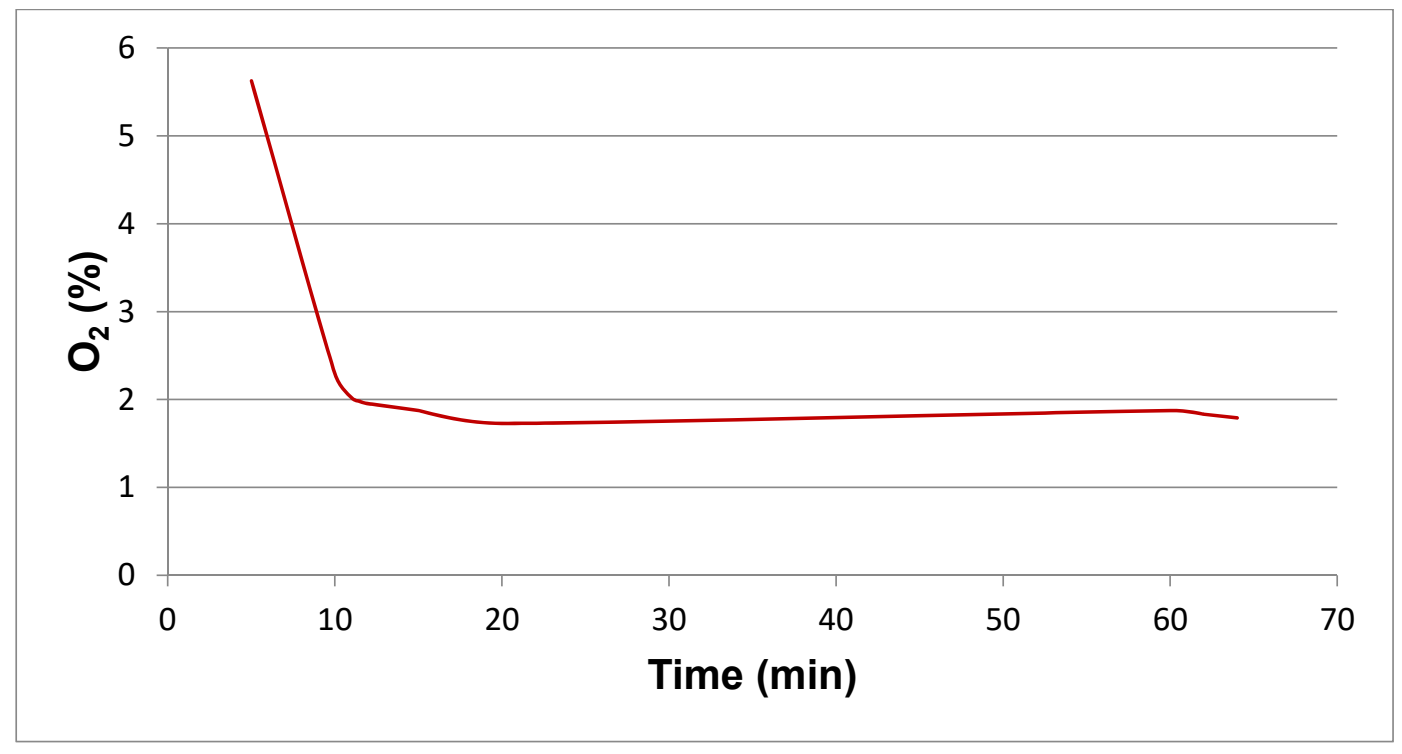

Figure 16. Medium saturation with $\mathrm{pO}_{2}(\%)$.

\subsection{Protein determination}

Protein quantitation was performed, in the different cellular extracts, by the BCA protein assay kit (Pierce), according with the manufacturer's instructions. Samples were measured at least by triplicate and Bovine Serum Albumin (BSA) was used as standard.

\subsection{Western blotting}

To perform Western Bolt Analysis cellular extracts were prepared in RIPA buffer (1\% SDS, $2 \mathrm{mM}$ EDTA, $12.5 \mathrm{mM} \mathrm{Na} \mathrm{HPO}_{4}, 1 \%$ TritonX-100 and $150 \mathrm{mM} \mathrm{NaCl} \mathrm{pH}$ 7), supplemented with protease inhibitors ( $100 \mu \mathrm{M}$ phenylmethylsulfonyl fluoride, $50 \mu \mathrm{g} / \mathrm{mL}$ antipapain, $50 \mu \mathrm{g} / \mathrm{ml}$ pepstatin, $50 \mu \mathrm{g} / \mathrm{ml}$ amastatin, $50 \mu \mathrm{g} / \mathrm{ml}$ leupeptin, $50 \mu \mathrm{g} / \mathrm{mL}$ bestatin, 
$1 \mathrm{mM}$ o-vanadate, $50 \mathrm{mM} \mathrm{NaF}$, and $50 \mu \mathrm{g} / \mathrm{ml}$ soybean trypsin inhibitor) and boiled for $5 \mathrm{~min}$. Cell lysate was obtained by scraping the cells in the culture plate in presence of RIPA followed by $5 \mathrm{~min}$ of boiling and $5 \mathrm{~min}$ of sonication $(37 \mathrm{kHz}$; FB 15050 Ultrasonic unit, Thermo-Fisher).

Unless otherwise stated, aliquots of $50 \mu \mathrm{g}$ protein, were subjected to sodium dodecylsulfate-polyacrylamide gel electrophoresis (SDS-PAGE) onto 8, 10 or 12\% acrylamide gels (MiniProtean ${ }^{\circledR}$, Bio-Rad) including Dual Colors ${ }^{\mathrm{TM}}$ (BioRad) as prestained protein ladder. The resolved proteins were transferred electrophoretically to nitrocellulose membranes (Amersham protran premium 0.45 nitrocellulose, Amersham). Membranes were blocked with $5 \%(\mathrm{w} / \mathrm{v})$ low-fat milk in $20 \mathrm{mM}$ Tris, $150 \mathrm{mM} \mathrm{NaCl}$, and $0.1 \%(\mathrm{w} / \mathrm{v})$ Tween 20, pH 7.5, for $1 \mathrm{~h}$. After blocking, membranes were immunoblotted overnight at $4^{\circ} \mathrm{C}$, with anti-HIF1 $\alpha$ (1/200 v/v) (sc-10790, Santa Cruz Biotechnologies), Anti-PGD $(1 / 5000 \mathrm{v} / \mathrm{v})(\mathrm{ab} 129199$, Abcam, Cambridge, United Kingdom) or anti- $\beta$-actin $(1 / 30,000$ v/v) (A5441, Sigma) as primary antibodies, and horseradish peroxidase-conjugated goat anti-rabbit IgG (dilution 1:10,000 v/v, Santa Cruz Biotechnologies) and/or goat anti-mouse $\operatorname{IgG}$ (dilution 1/10,000 v/v, Sigma and BioRad) as secondary antibodies (see table 3 for a full list of used antibodies). After incubation with the secondary antibody, membranes were immediately incubated either for $2 \mathrm{~min}$ with the enhanced chemiluminescence kit WesternBright ECL (Advansta) or for $1 \mathrm{~min}$ with Immobilon Western (Millipore, USA), before exposure to Fuji Medical X-Ray film (Fujifilm), and the autoradiograms were scanned. At least, three independent replicates were performed, and a representative Western blot is shown, together with densitometric analysis (ImageJ). 


$\begin{array}{llc}\text { Primary antibodies } & \text { Reference } & \text { Dilution } \\ \text { anti-HIF1 } \alpha & \text { sc-10790, Santa Cruz } & 1 / 200 \\ \text { anti-PGD (6PGDH) } & \text { ab129199, Abcam } & 1 / 5000 \\ \text { anti- } \beta \text {-actin } & \text { A5441, Sigma } & 1 / 30000 \\ \text { anti-HKII } & \text { sc-6521, Santa Cruz } & 1 / 500 \\ \text { anti-AMPK } & \text { 2532, Cell Signalling } & 1 / 1000 \\ \text { anti-pAMPK } & \text { 2531, Cell Signaling } & 1 / 1000 \\ \text { anti-ACC } & \text { 3662, Cell Signaling } & 1 / 1000 \\ \text { anti-pACC } & \text { 3661, Cell Signaling } & 1 / 1000 \\ \text { anti-Lamin B1 } & \text { sc-374015, Santa Cruz } & 1 / 100 \\ \text { anti-SOD2 } & \text { MAB3419-SP, Novus Biological } & 1 / 1000 \\ \text { anti-NDUFA9 } & \text { ab14713, Abcam } & 1 / 1000 \\ \text { anti-ATP } \beta & \text { ab14730, Abcam } & 1 / 1000 \\ \text { anti-MTCO1 } & \text { ab14705, Abcam } & 1 / 1000 \\ \text { anti-SDHA } & \text { ab14715, Abcam } & 1 / 1000 \\ \text { anti-OPA1 } & \text { 612606, BD Biosciences } & 1 / 1000 \\ \text { anti-GRP75 } & \text { sc-13967, Santa Cruz } & 1 / 5000 \\ \text { anti-TOM20 } & \text { ab56783, Abcam } & 1 / 5000 \\ \text { Secondary antibodies } & & \\ \text { goat anti-rabbit IgG } & \text { sc-2030, Santa Cruz } & 1 / 10000 \\ \text { goat anti-mouse IgG } & 170-6516, \text { BioRad } & 1 / 10000\end{array}$

Table 3. Primary and secondary antibodies used for Western Blot.

\subsection{Mitochondrial complexes analysis}

\subsubsection{Mitochondrial isolation}

Mitochondria were isolated according to Acín-Pérez et al. (Acin-Perez et al., 2008). Cocultured cells (107) were collected using trypsin/EDTA solution, and frozen at $-80^{\circ} \mathrm{C}$ to facilitate cell breakage. Cell pellets were homogenized using Potter-Elvehjem glass-teflon homogenizer backed with electrical support, and adding about 10 cell pellet volumes of homogenizing buffer A $\quad(83 \quad \mathrm{mM}$ sucrose, $10 \mathrm{mM}$ MOPS (3-(Nmorpholino)propanesulfonic acid)), $\mathrm{pH}$ 7.2). An equal volume of buffer $\mathrm{B}$ (250 $\mathrm{mM}$ sucrose, $30 \mathrm{mM}$ MOPS, $\mathrm{pH}$ 7.2) was added and samples were centrifuged at $1000 \mathrm{x} \mathrm{g}$ during 5 min to remove unbroken cells and nuclei. Mitochondria were collected from the supernatant by centrifuging at $12000 \mathrm{x} g$ during $3 \mathrm{~min}$. The pellets were washed with buffer C (320 mM sucrose, 1 mM EDTA, 10 mM Tris-HCl, $\mathrm{pH}$ 7.4) and centrifugation repeated 
at the same conditions. Mitochondrial pellets were suspended in an appropriate volume $(75-100 \mu \mathrm{L})$ of buffer D (1 M 6-amiohexanoic acid, $50 \mathrm{mM}$ Bis-Tris-HCl, $\mathrm{pH} 7.0)$, and the membrane proteins were solubilized with digitonin $(4 \mathrm{~g} / \mathrm{g})$ and incubated for $5 \mathrm{~min}$ in ice. A 30 min centrifugation at $13000 \mathrm{x} g$ was performed, then the supernatant containing the solubilized mitocondria was collected.

\subsubsection{BNGE (Blue Native Gel Electrophoresis) and transfer}

The extracted and solubilised mitochondria $(8 \mu \mathrm{g})$ were separated electrophoretically in native gels (Native PAGE Novex 3-12\% Bis-Tris Protein Gels, Thermo Scientific) in order to evaluate the arrangement of the complexes in the electron transport chain. The mitochondrial samples were loaded in $10 \%(\mathrm{v} / \mathrm{v})$ loading buffer (5\% (v/v) Serva-Blue G; 1 M 6-aminohexanoic acid). The electrophoresis was carried out at $100 \mathrm{~V}$ for 1 hour in the presence of blue cathode buffer $(50 \mathrm{mM}$ tricine; $15 \mathrm{mM}$ Bis-Tris/HCl; $0.02 \%(\mathrm{w} / \mathrm{v})$ Coomassie Brilliant Blue G; pH 7) in the cathode chamber, and anode buffer (50 mM BisTris; $\mathrm{pH}$ 7) in the anode chamber, followed by buffer replacement (removal of Coomassie blue dye) in the cathode chamber and electrophoresis at $40 \mathrm{~V}$ overnight at $4{ }^{\circ} \mathrm{C}$.

The gel containing the separated proteins was then incubated at $4{ }^{\circ} \mathrm{C}$ in carbonated transfer buffer (10 mM NaHCO3; 3 mM Na2CO3•10H20; pH 9.5-10) for 20 minutes with agitation to ensure the gel was fully saturated with said transfer buffer. The transfer was then carried out onto polyvinylidene difluoride (PVDF) membranes (Thermo Scientific) (previously activated with methanol) at $60 \mathrm{~V}$ for 90 minutes at $4^{\circ} \mathrm{C}$ in the Mini-Transblot system (BioRad, U.S.A.). The membranes were then subjected to normal western blot protocol (see section 3.5).

\subsubsection{In gel activity of complexes, I and V}

The activity of complex I, and complex V was evaluated using in gel activity assays. For this, after electrophoresis, gels were washed in running buffer to eliminate any rest of loading buffer.r the assay of complex I, gels were incubated in fresh activity solution $(0.1$ $\mathrm{M}$ Tris-HCl pH 7.4, $1 \mathrm{mg} / \mathrm{mL}$ nitro blue tetrazolium chloride (NTBZ), $0.14 \mathrm{mM} \mathrm{NADH)}$ at room temperature during 30-60min (Diaz et al., 2009). Reaction was stopped by washing the gels with distilled water. Apparition of blue-purple precipitate indicate the activity of NADH oxidase, one of the activities of complex I, confirming by this manner the localization of this complex. 
In the case of complex $\mathrm{V}$, gels were equilibrated in $50 \mathrm{mM}$ Tris solution ( $\mathrm{pH}$ 8.6) during 1 hour. After that, the activity assay was developed by the incubation of cells 3 hours at $37^{\circ} \mathrm{C}$, in the presence of a freshly prepared solution (35 mM Tris, $270 \mathrm{mM}$ glycine, $14 \mathrm{mM}$ $\mathrm{MgSO}_{4}, 5$ mM ATP, 0.2\% $\mathrm{Pb}\left(\mathrm{NO}_{3}\right)_{2} ; \mathrm{pH}$ 8.6) (Diaz et al.; 2009).

\subsection{Mitochondrial membrane potential}

$\Delta \psi_{\mathrm{m}}$ was assessed by flow cytometry using the probe $\operatorname{DiIC1}(5)\left(1,1^{\prime}, 3,3,3^{\prime}, 3^{\prime}-\right.$ hexamethylindodicarbo-cyanine iodide) (Life Technologies) $(50 \mathrm{nM})$, a cationic cyanine dye, that accumulates in cells in response to membrane potential (Shapiro et al., 1979) (fig. 17). For this purpose, Cells were smoothly harvested by $\mathrm{T} / \mathrm{E}$ solution and washed as previously described. Centrifugations were performed with an Eppendorf, Centrifuge 5702, for samples cultured at $21 \% \mathrm{O}_{2}$ and a Fisherbrand ${ }^{\mathrm{TM}}$, minicentrifuge HS120119 for samples cultured at physiological $\mathrm{O}_{2}$ condition. After centrifugations, cells were suspended in phosphate-buffered saline (PBS, $136 \mathrm{mM} \mathrm{NaCl}, 2.7 \mathrm{mM} \mathrm{KCl}, 7.8 \mathrm{mM} \mathrm{Na}_{2} \mathrm{HPO}_{4} 2 \mathrm{H}_{2} \mathrm{O}, 1.7$ $\mathrm{mM} \mathrm{KH}_{2} \mathrm{PO}_{4} \mathrm{pH}$ 7.4). After a first counting in the cytometer, $10 \mu \mathrm{M}$ of carbonyl cyanide 3chlorophenylhydrazone (CCCP), a mitochondrial uncoupler, was added for 15 minutes to disrupt mitochondrial membrane potential and thus to permit defining the depolarized value. Cells were counted again and $\Delta \psi \mathrm{m}$ values were expressed in arbitrary units.

a)

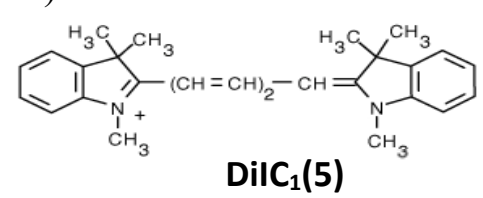

b)

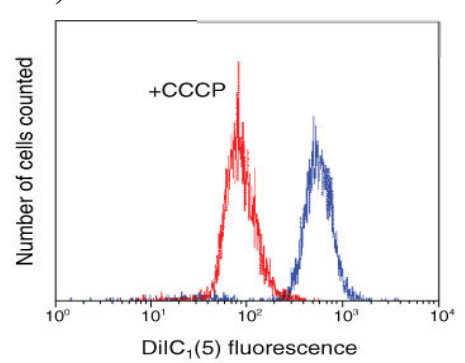

c)

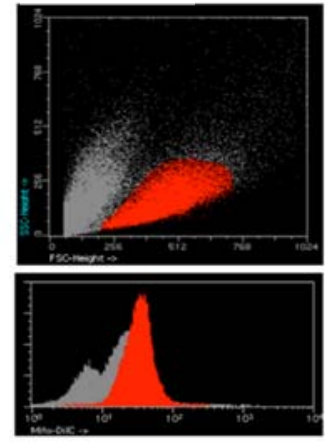

Figure 17. Mitochondrial membrane potential measurment. a) DiIC1(5) 1,1',3,3,3',3'-hexamethylindodicarbo-cyanine iodide; b) Decrease in DiIC1(5) fluorescence with the addition of CCCP; c) Flow cytometry analysis. 


\subsection{Determination of reactive oxygen species}

\subsubsection{Superoxide detection}

Levels of mitochondrial $\mathrm{O}_{2}{ }^{--}$were measured using MitoSox-Red ${ }^{\mathrm{TM}}$ (Invitrogen, Thermo Fisher Scientific), a fluorogenic marker that selectively binds $\mathrm{O}_{2}{ }^{--}$in live cells mitochondria, exhibiting red fluorescence when oxidized (fig. 18). To perform the assays, neurons and astrocytes were incubated with $2 \mu \mathrm{M}$ MitoSox-Red ${ }^{\mathrm{TM}}$ in Hank'S Balanced Salt Solution (HBSS: $134.2 \mathrm{mM} \mathrm{NaCl} ; 5.26 \mathrm{mM} \mathrm{KCl} ; 0.43 \mathrm{mM} \mathrm{KH}_{2} \mathrm{PO}_{4} ; 4.09 \mathrm{mM} \mathrm{NaHCO} ; ; 0.33 \mathrm{mM}$ $\mathrm{Na}_{2} \mathrm{HPO}_{4} \cdot 2 \mathrm{H}_{2} \mathrm{O} ; \quad 5.44 \mathrm{mM}$ glucosa; $20 \mathrm{mM}$ HEPES [4-(2-hydroxyethyl)-1piperazineethanesulfonic acid]; $4 \mathrm{mM} \mathrm{CaCl}_{2} \cdot 2 \mathrm{H}_{2} \mathrm{O} ; \mathrm{pH}$ 7.4) for $30 \mathrm{~min}$, washed with $\mathrm{PBS}$ and carefully detached from the plate with Trypsin/EDTA solution and the reaction was stopped by adding $10 \%$ of FCS. As a positive control, cells were incubated for $15 \mathrm{~min}$ in presence of $10 \mu \mathrm{M}$ Antimycin A to stimulate mitochondrial superoxide production. MitoSox-Red ${ }^{\mathrm{TM}}$ fluorescence has then been assessed by flow cytometry in a FACScalibur flux cytometer, analyzed using CellQuest ${ }^{\mathrm{TM}}$ PRO and Paint-A-Gate ${ }^{\mathrm{TM}}$ PRO (BD Biosciences) software and results expressed as arbitrary units (a.u.).
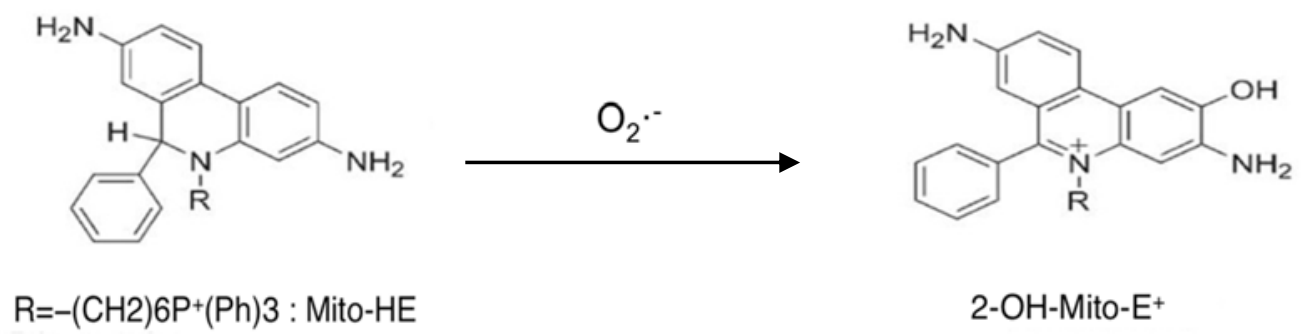

Figure 18. MitoSox ${ }^{\circledR}$ reaction with superoxide.

\section{$\underline{\text { 3.8.2. } \mathrm{H}_{2} \mathrm{O}_{2}} \underline{\text { determination }}$}

Production of $\mathrm{H}_{2} \mathrm{O}_{2}$ was assessed in media of intact seeded cells, in 96 well plates. Cells were incubated in a Krebs-Ringer phosphate glucose buffer (KRPG; $145 \mathrm{mM} \mathrm{NaCl}, 5.7$ $\mathrm{mM} \mathrm{Na} 2 \mathrm{PO}_{4}, 4.86 \mathrm{mM} \mathrm{KCl}, 0.54 \mathrm{mM} \mathrm{CaCl} 2,1.22 \mathrm{mM} \mathrm{MgSO}_{4}$ and $5.5 \mathrm{mM}$ glucose), containing $100 \mu \mathrm{M}$ AmplexRed probe (Invitrogen) and $0.5 \mathrm{U} / \mathrm{mL}$ of horseradish peroxidase. Luminescence was recorded for $2 \mathrm{~h}$ at $30 \mathrm{~min}$ intervals using a Varioskan Flash (Thermo Scientific, Rockford, IL, USA) fluorimeter (excitation: $538 \mathrm{~nm}$, emission: 604 $\mathrm{nm})$, and the slopes of linear regressions of luminescence vs. time were used for the calculations. 
In the co-cultures and cells cultivated at $5 \% \mathrm{O}_{2}$, production of $\mathrm{H}_{2} \mathrm{O}_{2}$ was assessed in $100 \mu \mathrm{L}$ media samples, collected at 30 min intervals, for $2 \mathrm{~h}$, in 96 well plates and luminescence was recorded in a single lecture with the Varioskan Flash, as before.

\subsection{Analysis of apoptotic cell death}

Apoptosis was assessed by Annexin V Apoptosis Detection Kit with 7-AAD by flow cytometry (fig. 19). The Annexin $\mathrm{V}$ is a member of the intracellular annexin protein family, that binds to phosphatidylserine (PS) in a calcium-dependent manner. PS is normally only found on the intracellular leaflet of the plasma membrane in healthy cells, but during early apoptosis, membrane asymmetry is lost and PS translocates to the external leaflet. Fluorochrome-labeled Annexin V can then be used to specifically target and identify apoptotic cells. Annexin V binding by itself cannot differentiate between apoptotic and necrotic cells. To help distinguish between them we use 7-amino-actinomycin D (7-AAD) simultaneously. Early apoptotic cells will exclude 7-AAD, while late stage apoptotic cells will stain positively, due to the passage of the dye into the nucleus where it binds to DNA. After 15 minutes of incubation at $37^{\circ} \mathrm{C}$ with annexin $\mathrm{V}$ and $7-\mathrm{AAD}$ in binding buffer (100mM HEPES, $140 \mathrm{mM} \mathrm{NaCl}, 2.5 \mathrm{mM} \mathrm{CaCl}_{2}$ ), cells were carefully detached from the plates using 1mM EDTA (tetrasodium salt) in PBS (pH 7.4) for neurons or Trypsin/EDTA followed by $10 \%$ FCS for astrocytes, centrifuged for 5 minutes at $500 \mathrm{x} \mathrm{g}$ of $\mathrm{rcf}$ then resuspended in PBS previous to quantification on a FACScalibur flow cytometer $(15 \mathrm{~mW}$ argon ion laser tuned at $488 \mathrm{~nm}$ ) and analyzed using CellQuest ${ }^{\mathrm{TM}} \mathrm{PRO}$ and Paint-A-Gate ${ }^{\mathrm{TM}}$ PRO (BD Bioscences) software. Only annexin V-stained cells that were 7-AAD-negative were considered apoptotic.
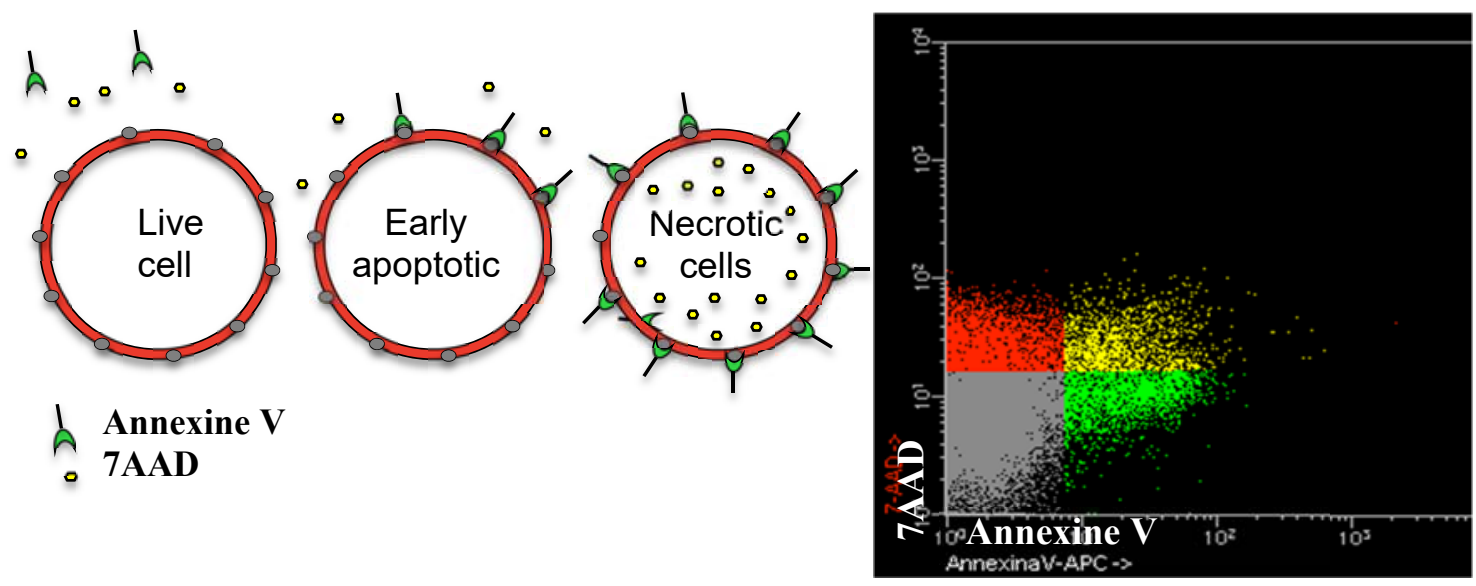

Figure 19. Apoptosis detection. 


\subsection{Determination of media metabolites}

\subsubsection{Sample collection and deproteinization}

To measure the metabolite concentrations in culture media, cells were washed twice with PBS for 10 min each and new Neurobasal ${ }^{\circledR}-A$ MAO was added. Cells were incubated for 24 hours and $250 \mu \mathrm{L}$ medium samples were collected at different time intervals and deproteinized with $25 \mu \mathrm{L}$ of $20 \%$ w/v perchloric acid (PCA; $\left.\mathrm{ClO}_{4} \mathrm{H}\right)$. Deproteinized media were diluted (1:1) with $\mathrm{H}_{2} \mathrm{O}$ and neutralized with $4 \mathrm{M} \mathrm{KOH}$ (25 to $27 \mu \mathrm{L}$ per sample) to about $\mathrm{pH}=6.5-7.0$ in presence of $30 \mu \mathrm{L}$ of internal $\mathrm{pH}$ indicator (Full Range Indicator, Fisher Scientific, Massachusetts, United States). Samples were incubated on ice for $30 \mathrm{~min}$ and centrifuged for $5 \mathrm{~min}$ at $10,000 \mathrm{x} \mathrm{g}(\mathrm{RCF})$ and $4^{\circ} \mathrm{C}$ in an Eppendorf, Centrifuge 5424 R (Hamburg, Germany) previous to supernatant collection.

\subsubsection{Glucose determination}

D-Glucose was measured spectrophotometrically (fig. 20), according with the method described by Bergmeyer et al. (1974), by reading the increase in $\mathrm{NADPH}\left(\mathrm{H}^{+}\right)$absorbance at $340 \mathrm{~nm}$ produced in two coupled reactions, catalyzed by hexokinase and glucose-6phosphate dehydrogenase (G6PD) (Roche diagnostics Corporation, Mannheim, Germany) after 10 minutes incubation.

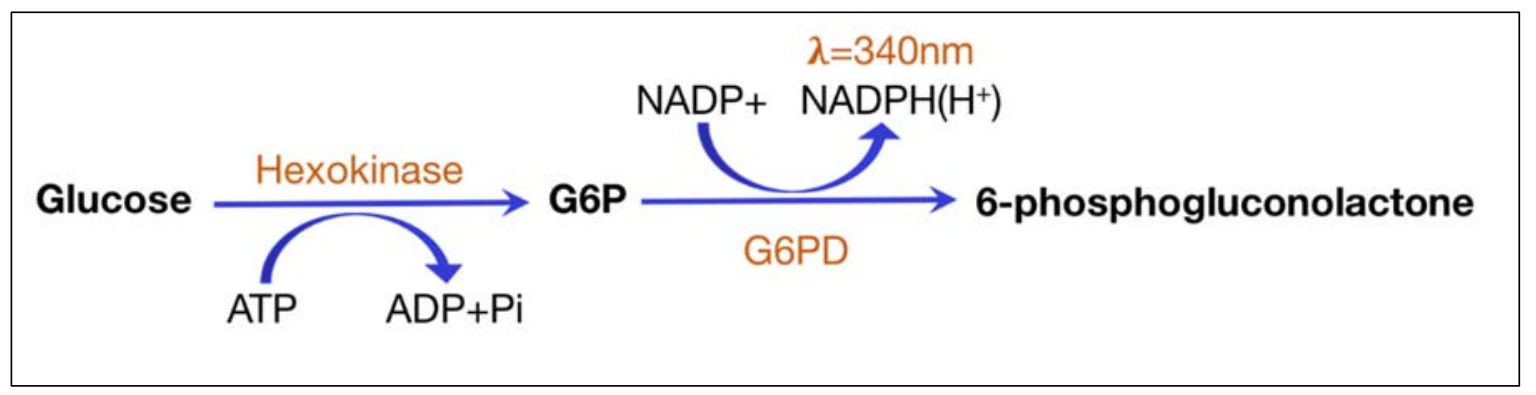

Figure 20. D-glucose determination. The reaction buffer was: $2 \mathrm{U} / \mathrm{mL}$ Hexokinase, $1 \mathrm{U} / \mathrm{mL}$ G6PD, 0.38 mM ATP, $0.38 \mathrm{mMNADP}+, 3.8 \mathrm{mM} \mathrm{MgCl}_{2}$ and $38.5 \mathrm{mM}$ Tris- $\mathrm{HCl} \mathrm{pH} 8$. 


\subsubsection{L-lactate}

L-lactate was measured spectrophotometrically (fig. 21), according to the method of Gutmann and Wahlefeld (Gutmann \& Wahlefeld, 1974). The increase in the absorbance of $\mathrm{NADH}(\mathrm{H}+)$ produced in the reaction catalyzed by lactate dehydrogenase (LDH, Roche) was measured in a Varioskan Flash (Thermo Fischer, Vantaa, Finland) spectrofluorometer at $340 \mathrm{~nm}$ once reaction is ended. To assess extracellular lactate concentration, an aliquot of the cell culture or experimental buffer was obtained after $1.5 \mathrm{~h}$ of incubation with the cells.

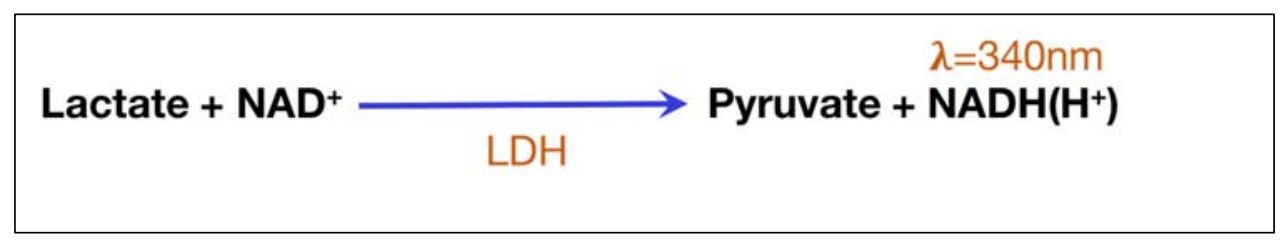

Figure 21. L-Lactate determination. The reaction buffer was $250 \mathrm{mM}$ glycine, $500 \mathrm{mM}$ hydrazine, $1 \mathrm{mM}$ EDTA, $1 \mathrm{mMNAD+} 22.5 \mathrm{U} / \mathrm{mL} \mathrm{LDH}$ ( $\mathrm{pH} 9.5$ ).

\subsubsection{6-phosphogluconate dehydrogenase activity}

a) Sample collection

Neurons/astrocytes 3 days' co-cultures were washed with PBS and cells carefully harvested with Trypsin/EDTA solution. Tripsinization was stopped by adding $10 \%$ of FCS. Cells were transferred to $15 \mathrm{~mL}$ Falcon tubes and centrifugated for 5 minutes at $500 \mathrm{rcf}$ and the supernatant discarded. A washing step was applied by addition of $3 \mathrm{~mL}$ of PBS and centrifugation at $500 \mathrm{xg}$. Cells were re-suspended in $1 \mathrm{~mL}$ HEPES buffer (50 mM HEPES, $100 \mathrm{mM} \mathrm{NaCl}, 5 \mathrm{mM} \mathrm{MgCl}, 0.5 \mathrm{mM} \mathrm{MnCl}_{2}, \mathrm{pH}$ 7.5) supplemented with protease inhibitors cocktail (100 $\mu \mathrm{M}$ phenylmethylsulfonyl fluoride, $50 \mu \mathrm{g} / \mathrm{mL}$ antipapain, $50 \mu \mathrm{g} / \mathrm{ml}$ pepstatin, $50 \mu \mathrm{g} / \mathrm{ml}$ amastatin, $50 \mu \mathrm{g} / \mathrm{ml}$ leupeptin, $50 \mu \mathrm{g} / \mathrm{mL}$ bestatin, $1 \mathrm{mM}$ o-vanadate, $50 \mathrm{mM} \mathrm{NaF}$, and $50 \mu \mathrm{g} / \mathrm{ml}$ soybean trypsin inhibitor) and lysed by 3 freezing-thawing cycles in liquid nitrogen and a $37^{\circ} \mathrm{C}$ thermostatic bath. The lysate was centrifuged at 13000 $\mathrm{x} \mathrm{g}$ for $5 \mathrm{~min}$ at $4^{\circ} \mathrm{C}$ and the supernatant was collected in a new $1.5 \mathrm{~mL}$ Eppendorf. 
6-Phosphogluconate dehydrogenase (6-PGDH) activity was measured spectrophotometrically according to an adaptation of the procedure described by Rippa M., Spanio L., and Pontremoli S. (Rippa et al., 1966; Spanio et al., 1966) (fig. 22). $30 \mu \mathrm{L}$ of the sample were added to $260 \mu \mathrm{L}$ of reaction buffer (HEPES buffer, $2 \mathrm{mM}$ NADP) to each well in a 96 well plate. The reaction was started by addition of $2 \mathrm{mM} 6$-phosphogluconic acid trisodium salt (Sigma-P7877, San Luis, Misuri, United States). Increases in the absorbance at $340 \mathrm{~nm}$ of the produced $\mathrm{NADPH}\left(\mathrm{H}^{+}\right)$were recorded for 20 minutes at $2 \mathrm{~min}$ intervals using a Varioskan Flash spectrofluorimeter (Thermo Scientific, Rockford, IL, USA).

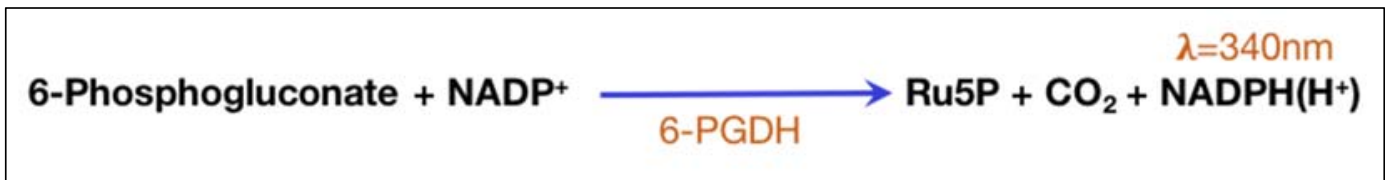

Figure 22. 6-Phosphogluconate dehydrogenase activity determination.

\subsection{Glycolytic flux assessment}

\section{$\underline{\text { 3.11.1. Glycolytic rate in cell cultures }}$}

The glycolytic flux was determined in attached cells by determining the production of ${ }^{3} \mathrm{H}_{2} \mathrm{O}$ from $\mathrm{D}-\left[3-{ }^{3} \mathrm{H}\right]$ glucose by the aldolase catalysed reaction, according with the procedure described by Rodriguez-Rodriguez, P. (Rodriguez-Rodriguez et al., 2012), with some modifications (fig. 23). Briefly: cells were seeded at 200.000 cells $/ \mathrm{cm}^{2}$ (neurons) or 75.000 cells $/ \mathrm{cm}^{2}$ (astrocytes) in $8.5 \mathrm{~cm}^{2}$ flasks and cultured with media changes every three days. At day 6 in culture, medium was discarded, followed by two PBS washing and a replacement by $1.5 \mathrm{~mL}$ of Neurobasal-A-MAO medium, supplemented with $5.5 \mathrm{mM} \mathrm{D}$ glucose and $5 \mu \mathrm{Ci}$ of $\mathrm{D}-\left[3-{ }^{3} \mathrm{H}\right]$ glucose per assay. A $1.5 \mathrm{~mL}$ Eppendorf tube containing 1 $\mathrm{mL}$ of water (for ${ }^{3} \mathrm{H}_{2} \mathrm{O}$ trapping) was fixed inside the flask by holding it from the flask tab using a rib. Flaks were incubated in oxygen controlled incubator for 2 hours without any cap in order to ensure adequate constant $\mathrm{O}^{2}$ supply throughout incubation period. Reaction was stopped by adding $0.2 \mathrm{~mL}$ of $20 \% \mathrm{w} / \mathrm{v}$ perchloric acid $\left(\mathrm{PCA} ; \mathrm{ClO}_{4} \mathrm{H}\right)$ and flasks were sealed with a rubber cap and incubated for additional 96 hours in a thermostatic orbital shaker, at $36^{\circ} \mathrm{C}$ (Zundorf et al., 2009),(Zundorf et al., 2009)(Zundorf et al., 2009) to allow equilibration of ${ }^{3} \mathrm{H}_{2} \mathrm{O}$ between the Eppendorf and the outer receptacle. The efficiency of 
${ }^{3} \mathrm{H}_{2} \mathrm{O}$ trapping in the Eppendorf tube in these experimental conditions, was determined in previous experiments of our laboratory, and showed to be of $28 \%$. Total radio-activities in the Eppendorf tube were measured to calculate amount of metabolized glucose. A triplicate was prepared for each culture condition. Proteins were measured with Pierce ${ }^{\mathrm{TM}}$ BCA Protein Assay Kit as indicated in section 3.4. Initial glucose concentration was determined spectrophotometrically as described in 3.10.2. Results were expressed as nmol of D-[3- $\left.{ }^{3} \mathrm{H}\right]$ glucose turned into ${ }^{3} \mathrm{H}_{2} \mathrm{O}$ per hour and per mg protein.

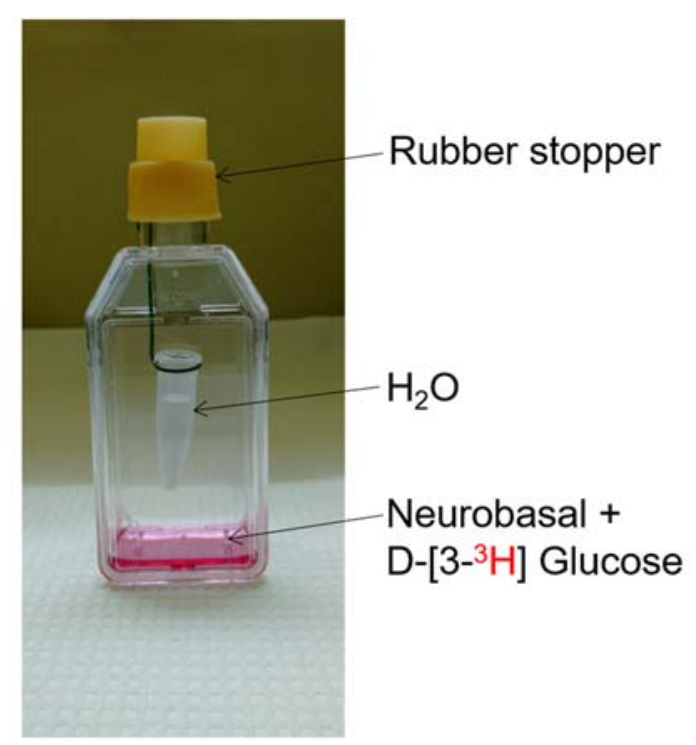

\section{Figure 23. Glycolytic flux hand-made determination} system.

\subsubsection{Glycolytic rate in co-culture}

Astrocytes were co-cultured on top of neurons in 6 well plates (as described in section 3.2.3.). At day 6 of neuronal culture (day 3 in co-culture), medium was removed and cells were washed two times with PBS and $1.5 \mathrm{~mL}$ of Neurobasal-A-MAO containing $5 \mu \mathrm{Ci}$ per flask of D-[3- $\left.{ }^{3} \mathrm{H}\right]$ glucose was added. Cells were incubated for 2 hours and incubation was stopped by adding perchloric acid to $2 \% \mathrm{w} / \mathrm{v}$ final concentration. $1.5 \mathrm{~mL}$ of medium were transferred to the bottom of $25 \mathrm{~cm}^{2}$ flasks containing a pending $1.5 \mathrm{~mL}$ Eppendorf tube (with $1 \mathrm{~mL}$ of water) as before. The flasks were sealed and the following steps were the same as described in 3.10.1. 


\subsection{Determination of incorporated bromodeoxyuridine}

Bromodeoxyuridine (BrdU) incorporation into DNA and cell cycle phase percentage were determined by flow cytometry. This was achieved after $1 \mathrm{~h}$ of incubation with $10 \mu \mathrm{M} \mathrm{BrdU}$ using the APC BrdU Flow Kit (BD Pharmingen ${ }^{\mathrm{TM}}$, Biosciences, San Jose, USA).

Following the manufacturer's instructions, neurons were fixed, permeabilized using the BD Cytofix/Cytoperm ${ }^{\mathrm{TM}}$ Buffer and resuspended with DNase $(300 \mu \mathrm{g} / \mathrm{mL})$ during $1 \mathrm{~h}$ at $37^{\circ} \mathrm{C}$ to expose BrdU epitopes. After staining with APC fluorochrome-conjugated monoclonal anti-BrdU antibody, fluorescent signals were analysed by flow cytometry $\left(3 \times 10^{5}\right.$ cells per condition) in channels FL4 (BrdU) and FL1 ( $\mathrm{GFP}^{+}$neurons) of FACScalibur Cytometer (Cuende et al., 2008; Delgado-Esteban et al., 2013).

\subsection{Real-Time or quantitative Polymerase Chain Reaction (RT-qPCR) and transcriptomic microarrays}

\section{$\underline{\text { 3.13.1 Microarrays and RT-qPCR sample collection }}$}

Cultures of $1.5-2 \times 10^{6}$ cells in $10 \mathrm{~cm}^{2}$ wells were washed twice with PBS and lysed during 5 min with $200 \mu \mathrm{L} /$ well of RLT buffer provided by the kit manufacturer (RNeasy® Mini Kit, Qiagen, cat. 74104). Cellular lysates were centrifuged for $3 \mathrm{~min}$ at $13000 \mathrm{xg}$ and the supernatants collected. 1 volume of $70 \%$ ethanol was added to the supernatants and $700 \mu \mathrm{L}$ of the sample were transferred to an RNeasy Mini spin column. Samples were centrifuged for $15 \mathrm{~s}$ at $\geq 8000 \mathrm{x}$ g and the flow-through was discarded. A step of DNase digestion was practised adding $80 \mu \mathrm{L} /$ sample of DNase I mix (10 $\mu \mathrm{L}$ DNase I + $70 \mu \mathrm{L}$ DNase buffer 10x) for 15 min. DNase reactions were stopped by adding $700 \mu \mathrm{L}$ of Buffer RW1 (provided by the manufacturer) and columns containing RNA samples were washed with two cycles of buffer RPE/centrifugation, discarding the eluates. RNA samples were collected into new collection tubes by adding $50 \mu \mathrm{L}$ of RNase-free water to the spin column membrane, followed by 1 min centrifugation at $\geq 8000 \mathrm{x} \mathrm{g}$. The RNA concentrations and purity were, verified by Nanodrop 2000 (Thermo Scientific) and kept at $-80^{\circ} \mathrm{C}$ until their use.

\subsubsection{Microarrays sample processing and analysis}

RNA samples of $100 \mathrm{ng} / \mu \mathrm{L}$ were used for Exon Arrays and Gene Arrays. Agilent Bioanalyzer were used to check quality and purity of the samples previous to affymetrix microarray hibridization using Clariom ${ }^{\mathrm{TM}} \mathrm{D}$ assays, mouse tools. 
Data was analysed using Transcriptomic Analysis Console (Thermo Fisher).

\subsubsection{RT-qPCR sample processing and analysis}

RT-qPCR was performed in total RNA samples, purified from co-cultured neurons using RNeasy ${ }^{\circledR}$ Mini Kit (as described in section 2.x), using Power SYBR Green RNA-to-CT 1Step kit (Applied Biosystems). Primers and conditions are summarized in table 4. The mRNA abundance of each transcript was normalized to the $\beta$-actin mRNA abundance (Housekeeping) obtained in the same sample. The resulting normalized values in neurons were expressed as the fold change versus the corresponding normalized values in neurons.

\begin{tabular}{ccccc}
\hline mRNA & Forward (5'-3') & Reverse (5'-3') & Concentration & Temperature \\
\hline HKII & TCTCAGAGCGCCTCAAGACAA & GATGGCACGAACCTGTAGCA & $0.2 \mu \mathrm{M}$ & $60^{\circ} \mathrm{C}$ \\
SOD2 & CTGGAGGCTATCAAGCGTGACTTT & CACGGCTGTCAGCTTCTCCTTAAA & $0.2 \mu \mathrm{M}$ & $60^{\circ} \mathrm{C}$ \\
ndufa412 & ACCCGCTTCTACCGGCAGATAAAA & ATGCCCAAGCAGATGAAGCCAA & $0.2 \mu \mathrm{M}$ & $60^{\circ} \mathrm{C}$ \\
6PGDH & ATCTCCTACGCCCAAGGCTTTATG & AATTGAGGGTCCAGCCAAACTCAG & $0.2 \mu \mathrm{M}$ & $60^{\circ} \mathrm{C}$ \\
PDK1 & CGTGATATGGGCAATCCGTAA & ACTGTGAAGATGAGTGACCGGG & $0.2 \mu \mathrm{M}$ & $60^{\circ} \mathrm{C}$ \\
CPT1A & GGATGGCTATGGTCAAGGTC & GGCCTCACAGACTCCAGGTA & $0.2 \mu \mathrm{M}$ & $60^{\circ} \mathrm{C}$
\end{tabular}

Table 4. Primers and RT-qPCR amplification conditions.

In real-time qPCR, amplification and detection process occur simultaneously, due to SYBR Green fluorescence, a fluorochrome that gets inserted into DNA strands. Since it binds only to double-stranded DNA, fluorescence increases proportionally to the quantity of PCR product amplified (amplicon). Temperature and concentration of primers necessary for RTqPCR were optimized measuring the efficiency for each pair of primers, using a serial RNA dilution. 100 ng of RNA were amplified in a final volume of $20 \mu \mathrm{L}$ (RT Enzyme Mix 125X, RT-PCR Mix 2X, forward y reverse oligonucleotides and nuclease free water). A triplicate of each reaction was performed in Mastercycler ${ }^{\circledR}$ ep realplex thermocycler (Eppendorf) in a thermal cycling conditions described in table 5 .

After amplification, we got the values of $\mathrm{Ct}$ (threshold cycle) for each reaction, which corresponds to the cycle where fluorescence emited by SYBR Green were first detected within the lineal fase. Following the comparative method of $\mathrm{Ct}$ (Biosystems, 2008; Bustin et al., 2009), the $\mathrm{Ct}$ increase $(\Delta \mathrm{Ct})$ is the difference between $\mathrm{Ct}$ of each gene and $\mathrm{Ct}$ of $\beta$ - 
actin (housekeeping or internal control). The relation of the number of copies obtained at the end of an optimal reaction was calculated from $2^{-\Delta \Delta \mathrm{Ct}}$ equivalent to $2^{-(\Delta \mathrm{Ct} \text { test sample }-\Delta \mathrm{Ct}}$

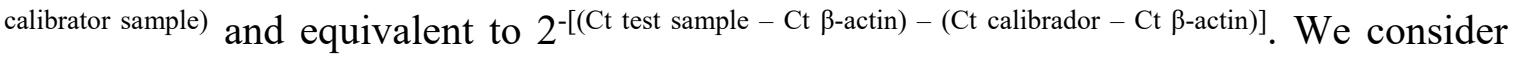
calibrator the condition to which we compare the expression and to which we normalise the results giving it 1 as value. Expression levels equal to 1, indicate that the test sample has the same expression of a particular gene as the control. Levels $>1$ indicate an increase of the expression compared to control, and levels $<1$ indicate a decrease compared to the control. Results were represented in arbitrary units of expression (fold or number of times of expression) between test sample and calibrator or control sample (relative quantification).

\begin{tabular}{|l|l|l|l|}
\hline \multicolumn{1}{|c|}{ Stage } & \multicolumn{1}{|c|}{ Step } & \multicolumn{1}{c|}{ Temp } & \multicolumn{1}{c|}{ Time } \\
\hline Holding & Reverse transcription & $48^{\circ} \mathrm{C}$ & $30 \mathrm{~min}$ \\
\hline \multirow{2}{*}{ Holding } & $\begin{array}{l}\text { Activation of AmpliTaq Gold }{ }^{\circledR} \\
\text { DNA Polymerase, UP(Ultra Pure) }\end{array}$ & $95^{\circ} \mathrm{C}$ & $10 \mathrm{~min}$ \\
\hline $\begin{array}{l}\text { Cycling } \\
(40 \text { cycles })\end{array}$ & Denature & $95^{\circ} \mathrm{C}$ & $15 \mathrm{sec}$ \\
\cline { 2 - 5 } & Anneal/Extend & $60^{\circ} \mathrm{C}$ & $1 \mathrm{~min}$ \\
\hline \multirow{2}{*}{$\begin{array}{l}\text { Melt curve } \\
\text { (Optional } *)\end{array}$} & Denature & $95^{\circ} \mathrm{C}$ & $15 \mathrm{sec}$ \\
\cline { 2 - 5 } & Anneal & $60^{\circ} \mathrm{C}$ & $15 \mathrm{sec}$ \\
\cline { 2 - 5 } & Denature & $95^{\circ} \mathrm{C}$ & $15 \mathrm{sec}$ \\
\hline
\end{tabular}

Table 5. Thermal cycling conditions. *To detect nonspecific amplification we perform a melting curve.

\subsection{Immunocytochemistry}

Cells were grown on glass coverslips previously treated with poli-L-ornitine $(15 \mu \mathrm{g} / \mathrm{mL})$ and fibronectine $(1 \mu \mathrm{g} / \mathrm{mL})$ (neurones) or PDL (astrocytes). At day 6 in culture they were washed with phosphate

buffered saline (PBS, $136 \mathrm{mM} \mathrm{NaCl}, 2.7 \mathrm{mM} \mathrm{KCl}, 7.8 \mathrm{mM} \mathrm{Na} 2 \mathrm{HPO}_{4} 2 \mathrm{H}_{2} \mathrm{O}, 1.7 \mathrm{mM}$ $\mathrm{KH}_{2} \mathrm{PO}_{4} \mathrm{pH}$ 7.4) then incubated for $30 \mathrm{~min}$, in their respective incubators, with the mitochondrial probe, CytoPainter (at 1/1,000 v/v) (Mitochondrial Staining Kit Red fluorescent, ab112145, Abcam). Cultures were washed with PBS then fixed with 4\% 
paraformaldehyde (v/v) in PBS for $10 \mathrm{~min}$. Afterward several short washes were practiced ( $5 \mathrm{~min}$ each) followed by $10 \mathrm{~min}$ room temperature incubation with nuclear marker DAPI (Sigma, Ref D9542, 1/7,000 v/v). Glass coverslips were then placed on a glass slide using SlowFade ${ }^{\circledR}$ (Molecular Probes, Oregon, USA) in order to avoid fluorescence loss. Confocal microscopy images were obtained using confocal spinning disk Roper Scientific with Olympus IX81 microscope.

\subsection{Statistical analysis}

Measurements from individual cultures were always carried out in triplicate. The results are expressed as mean \pm S.E.M. (standard error of the mean) values for three different culture preparations. For the comparisons between two groups of values, the statistical analysis of the results was performed by the Student's $t$ test. For multiple values comparisons, a test of homogeneity of variance was performed followed by one-way analysis of variance test (ANOVA), with the appropriated "post hoc" analysis depending on the homoscedasticity of the samples. In all cases, $\mathrm{P}<0.05$ was considered significant. 


\section{4- Results}

4.1. Changes in the survival and oxidative metabolism in neurons and astrocytes at physiological $\mathrm{pO}_{2}$

\section{$\underline{\text { 4.1.1. Pysiological } \mathrm{pO}_{2} \text { improves survival in cultured brain cells }}$}

Analysis of cell survival by flow cytometry using the Annexin V+/7AAD- technique reveals significant changes in the survival of astrocytes and neurons, in primary cutlures, at different $\mathrm{pO}_{2}$ compared with the atmospheric $\mathrm{pO}_{2}(21 \%)$ (fig. 24, a and b). In both line graphs, for astrocytes and neurons we notice an "U-Shape" that shows a decrease of apoptosis and so a better survival when $\mathrm{pO}_{2} \mathrm{p}$ is below $21 \%$ in a range between $6 \%$ to $5 \%$ $\mathrm{pO}_{2}$. Lower $\mathrm{pO}_{2}$ showed to be harmful for both types of cells.

a

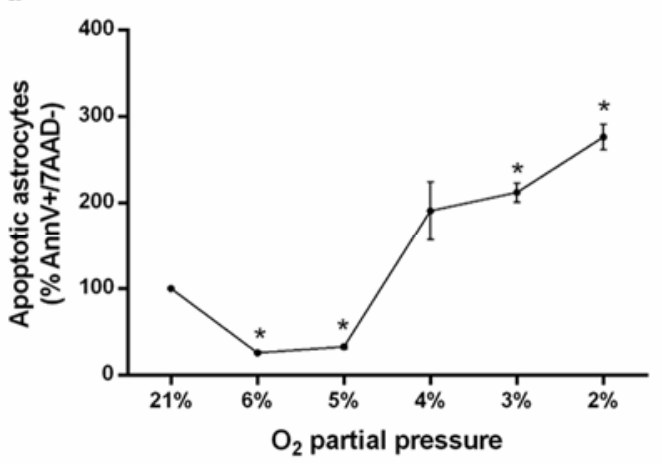

b

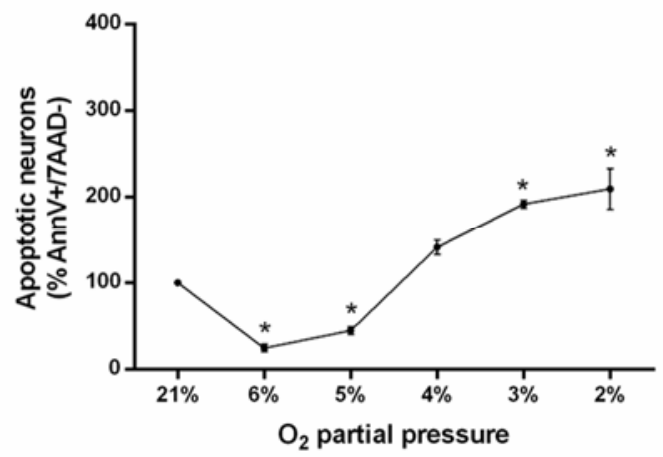

Figure 24. Effect of atmospheric $\mathrm{pO}_{2}$ on cell survival of astrocytes (a) and neurons (b) in primary cultures. Astrocytes and cortical neurons, were incubated during 6 days at the correspondent $\mathrm{pO}_{2}$, as described in 3.2. Apoptotic cells were quantified by flow cytometry using annexin V, 7AAD tests, as described in section 3.9. A test of homogeneity of variance was performed followed by one-way ANOVA with Tamhane post hoc test.

\subsubsection{Physiological $\mathrm{pO}_{2}$ have different effects on $\Delta \psi_{\mathrm{m}}$ in primary cultured astrocytes and} $\underline{\text { neurons }}$

Oxygen seems to have a direct effect on $\Delta \psi_{\mathrm{m}}$ of astrocytes and cortical neurons in primary cultures. By quantifying this parameter at different $\mathrm{pO}_{2}$ (fig. 25, a and b) we observed an inverted "U-Shaped" line in astrocytes, with significant increase at $6 \%$ and $5 \% \mathrm{pO}_{2}$. On the contrary, at the same $\mathrm{pO}_{2}$ values, neurons showed significant reductions in $\Delta \psi \mathrm{m}$. Otherwise, lower $\mathrm{pO}_{2}$ restored the $\Delta \psi_{\mathrm{m}}$ values seen at $21 \% \mathrm{pO}_{2}$. 

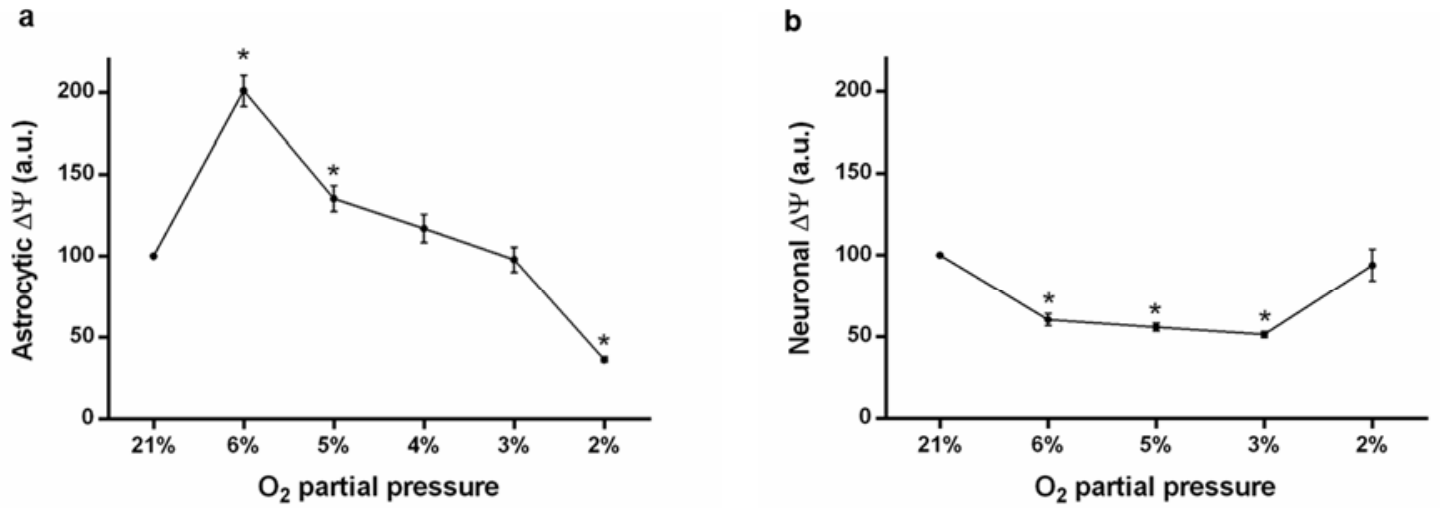

Figure 25. Effect of atmospheric p $\mathrm{O}_{2}$ on $\Delta \psi_{m}$ of astrocytes (a) and neurons (b) in primary cultures. Astrocytes and cortical neurons were incubated during 6 days at the correspondent $\mathrm{pO}_{2}$, as described in 3.2. $\triangle \psi_{m}$ was measured by flow cytometry using DiIC1(5) and the uncoupler CCCP, as described in section 3.7. A test of homogeneity of variance was performed followed by one-way ANOVA with Tamhane post hoc test.

\subsubsection{Physiological $\mathrm{pO}_{2}$ have different effects on $\mathrm{mROS}$ production in primary cultured} astrocytes and neurons

Although for some $\mathrm{pO}_{2}$ significant fluctuations could be seen, there was no major effect of atmospheric $\mathrm{pO}_{2}$ on mROS production in astrocytes (fig. 26a). Such a result seems to indicate a fairly stabilized mROS production in astrocytes. On the contrary, in neurons (fig. 26b), we observed a "U-Shaped" curve with a maximum at 5\% $\mathrm{O}_{2}$. Then, the neuronal mROS production started to slow down significantly.
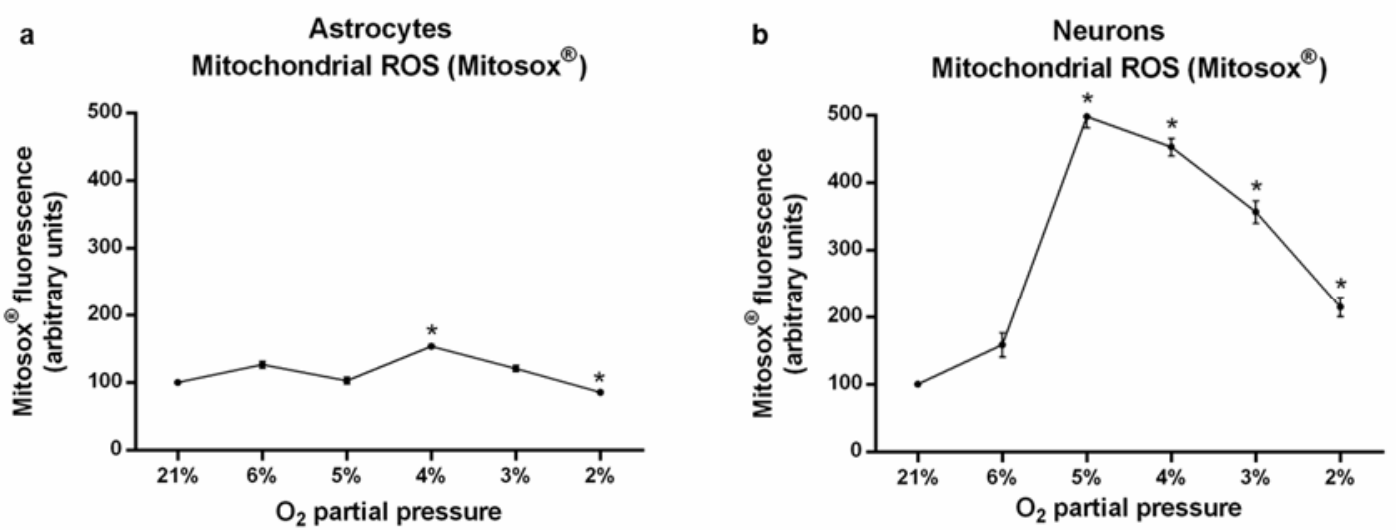

Figure 26. Effect of atmospheric p $\mathrm{O}_{2}$ on $\mathrm{mROS}$ production in astrocytes (a) and neurons (b). Astrocytes and cortical neurons were incubated during 6 days at the correspondent $\mathrm{pO}_{2}$ as described in 3.2. mROS were measured using the MitoSox $®$ assay in the intact cells by flow cytometry as described in section 3.8.1. A test of homogeneity of variance was performed followed by one-way ANOVA with Tamhane post hoc test. 


\subsection{Changes in mitochondrial structure of neurons and astrocytes at physiological $\mathrm{pO}_{2}$}

4.2.1. Physiological $\mathrm{pO}_{2}$ modulated mitochondrial shapes in primary cultured astrocytes and neurons

Three types of shape or conformation distinguished while analysing mitochondrial morphology: (i) small or fragmented mitochondria, (ii) large interconnected fibres or branched mitochondria and (iii) toroidal or "donuts-like" mitochondria. In astrocytes as well as in neurons, at $21 \% \mathrm{pO}_{2}$, the dominant conformation was the fragmented mitochondria (fig. 27, 28a and 29). However, in astrocytes, as the $\mathrm{pO}_{2}$ decreased close to the physiological values, mitochondria tend to form large interconnected networks. At lower oxygen tensions $(2 \%)$ the dominant form was the toroidal one. In neurons, the dominant form was fragmented mitochondria at all $\mathrm{pO}_{2}$ values, whereas branched mitochondria were not detected (fig. 29b).

To address whether different oxygen tension in culture induced modifications on mitochondrial morphology, we performed ultrastructural analysis of mitochondria in astrocytes and neurons exposed to $5 \%$ and $21 \% \mathrm{pO}_{2}$, respectively. As observed in fig. 27 and 28 , astrocytes' mitochondria adapted to reductions in $\mathrm{pO}_{2}$ changing from the small rounded mitochondria (fragmented) observed at $21 \% \mathrm{pO}_{2}$ (fig. $28 \mathrm{a}$ left side) to a more branched mitochondria (interconnected) after exposure to $5 \% \mathrm{pO}_{2}$ for 3 days (fig. 28a right side). This change in the mitochondrial structure paralleled a significant reduction in the cristae width (fig. 28b), as well as an increase in the number of cristae per surface unit (fig. 28c). Both changes indicate a substantial increase in the mitochondrial inner membrane surface.

As seen in fig. 29, interconnected mitochondria appears to be the main mitochondrial structural shape in astrocytes, at $\mathrm{pO}_{2}$ ranging from $4 \%$ to $6 \%$, whereas neurons lack such a structure. The abundance of mitochondrial toroid structures, though in a lesser extension, went in parallel to that of interconnected mitochondrial structures, except for $2 \% \mathrm{pO}_{2}$ where the toroid form became dominant. 


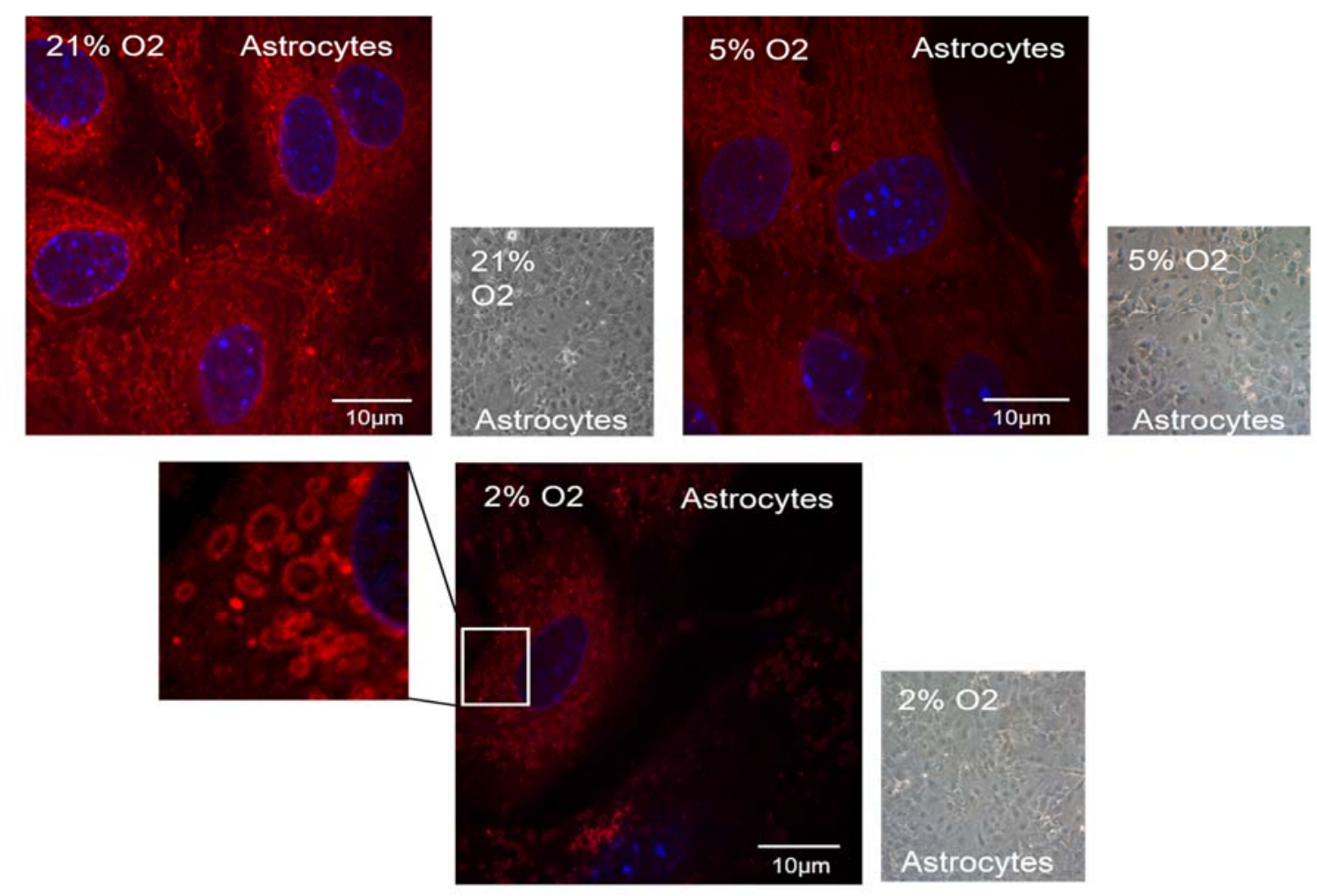

Figure 27a. Occurrence of toroid-like mitochondria in astrocytes grown under physiological-like $\mathrm{pO}_{2}$. Mitochondrial shape was revealed by Spinning-disk confocal microscope (100x) after CytoPainter ${ }^{\circledR}$ Red probes labelling to active mitochondria, and DAPI for the nucleus. Light contrast microscopy is used previously to double check the global state of the cells.

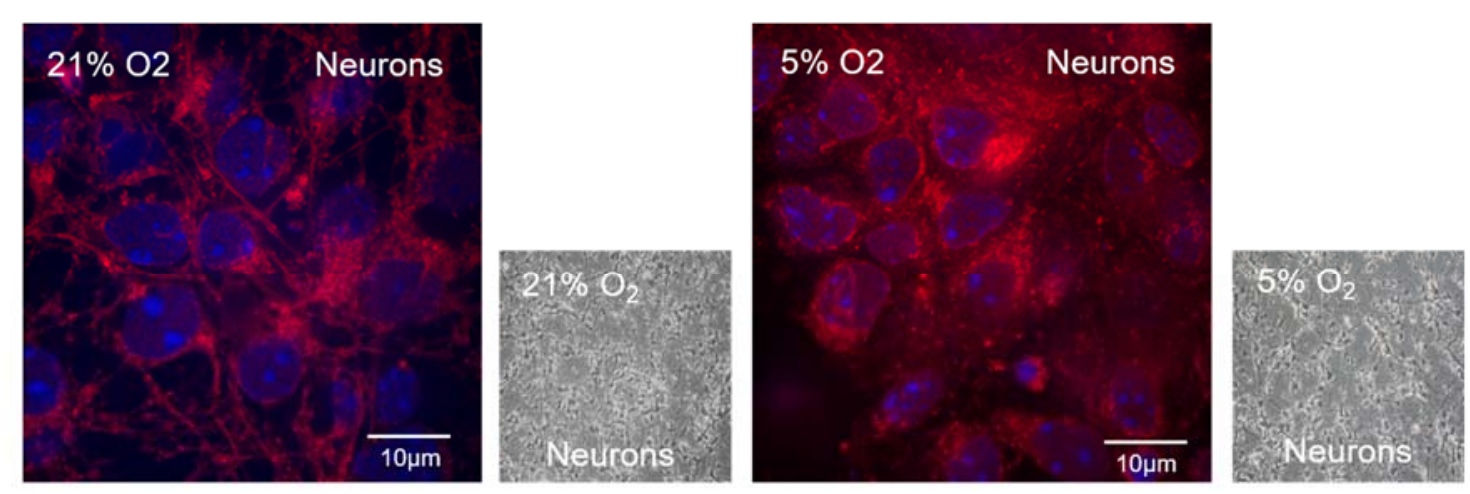

Figure 27b. Mitochondria in neurons grown under physiological-like p $\boldsymbol{O}_{2}$. Mitochondrial shape was revealed by Spinning-disk confocal microscope (100x) after CytoPainter ${ }^{\circledR}$ Red probes labelling to active mitochondria, and DAPI for the nucleus. Light contrast microscopy is used previously to double check the global state of the cells. 


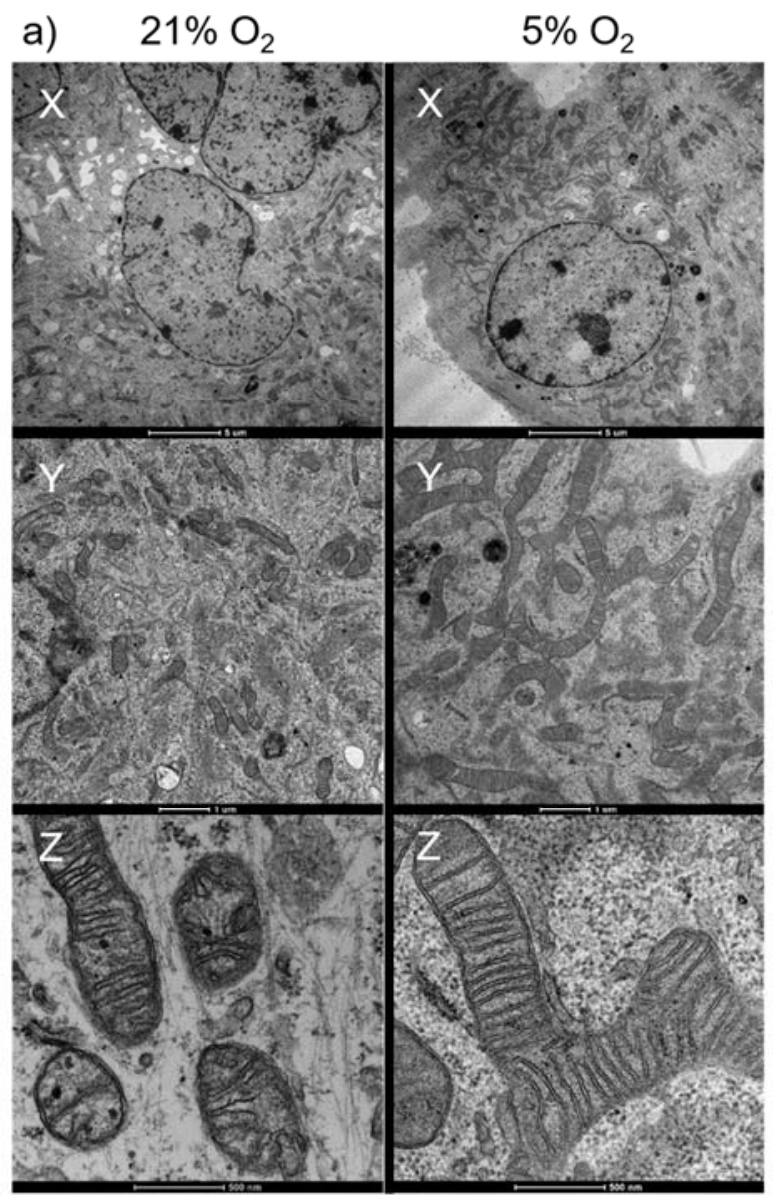

b)

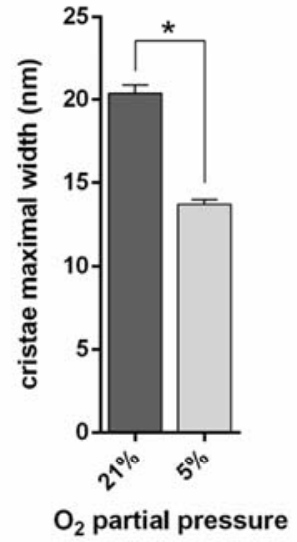

c)

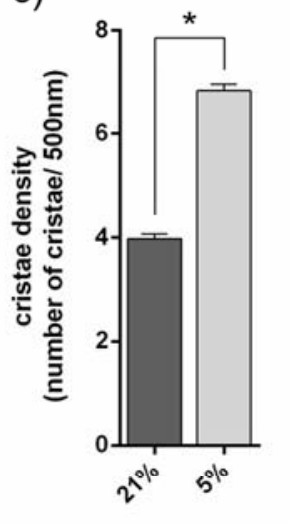

$\mathrm{O}_{2}$ partial pressure

Figure 28. Changes in mitochondrial structure of astrocytes at 5\% $\mathrm{pO}_{2}$ vs. 21\% $\mathrm{pO}_{2}$. (a) Transmission Electron Microscopy images (TEM) of astrocytes at 5\% $\mathrm{pO}_{2} \mathrm{vs} .21 \% \mathrm{pO}$, at different levels of amplification. Bar lengths: $5 \mu \mathrm{m}$ for the entire cell (X), $1 \mu \mathrm{m}$ for the cytoplasm (Y) and $500 \mathrm{~nm}$ for mitochondria (Z). (b) Cristae maximal width determination. Cristae width was measured for each and every mitochondrion in $Z$ pictures with a minimum of 60 mitochondria. (c) cristae density determination. Number of cristae was counted by each $500 \mathrm{~nm}$ of mitochondrion membrane in a minimum of 100 sections. Statistical tests of tStudent were carried out, with $p<0.01$ in all cases.
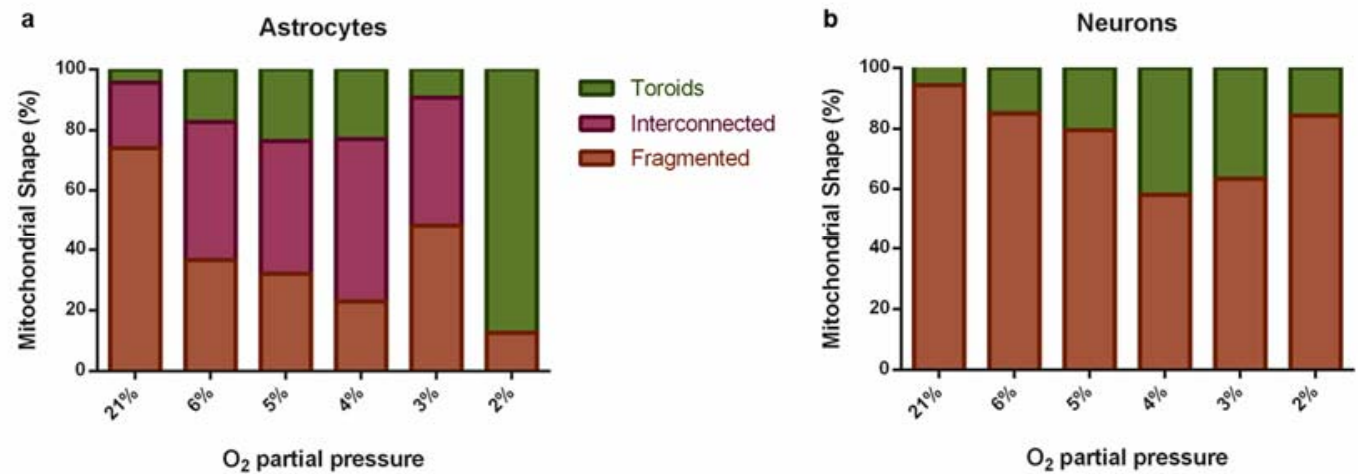

Figure 29. Quantification of the effect $\mathrm{pO}_{2}$ on mitochondrial shape in astrocytes (a) and neurons (b) in primary cultures. Quantification was performed by using the CytoPainter ${ }^{\circledR}$ Red probes to label active mitochondria. Spinning-disk confocal microscope was used to gather information about the shape and different conformations of the mitochondria. 
4.2.2. Differential expression of mitochondrial structure-related genes in primary cultured astrocytes and neurons at $5 \% \mathrm{pO}_{2}$ compared to $21 \% \mathrm{pO}_{2}$

Since the major changes in mitochondrial shape ocurred around the physiological 5\% O2 (see sections 4.1 and 4.2.1), we focused the following experiments in the comparative of that condition with the canonical $21 \% \mathrm{pO}_{2}$ normally used in most of primary brain cell cultures.. Thus, in order to explain the changes observed in mitochondrial ultrastructure under our experimental conditions, we studied the levels of Optic Atrophy 1 protein (OPA1), a master regulator of cristae shape and respiration, at $5 \% \mathrm{pO}_{2}$ compared to the $21 \%$ $\mathrm{pO}_{2}$.

As observed in fig. 30, neurons cultured at 5\% $\mathrm{pO}_{2}$ showed a $\sim 30 \%$ reduction in the abundance of the cristae core regulator OPA1 compared to $21 \% \mathrm{pO}_{2}$. On the contrary, in astrocytes the expression of OPA1 increased by about 5\%. Overlapping with the reduction in protein abundance, the profile of OPA1 isoforms changed in neurons cultured at $5 \% \mathrm{pO}_{2}$ when compared with $21 \% \mathrm{pO}_{2}$. We observed an increase in the $\mathrm{c}, \mathrm{d}$ and e isoforms with a reduction of the $\mathrm{a}$ and $\mathrm{b}$ isoforms (fig. 30). Conversely, astrocytes cultured at $5 \% \mathrm{pO}_{2}$ maintained the OPA1 isoforms profile with an increase in the detected amounts of OPA1 long isoforms.

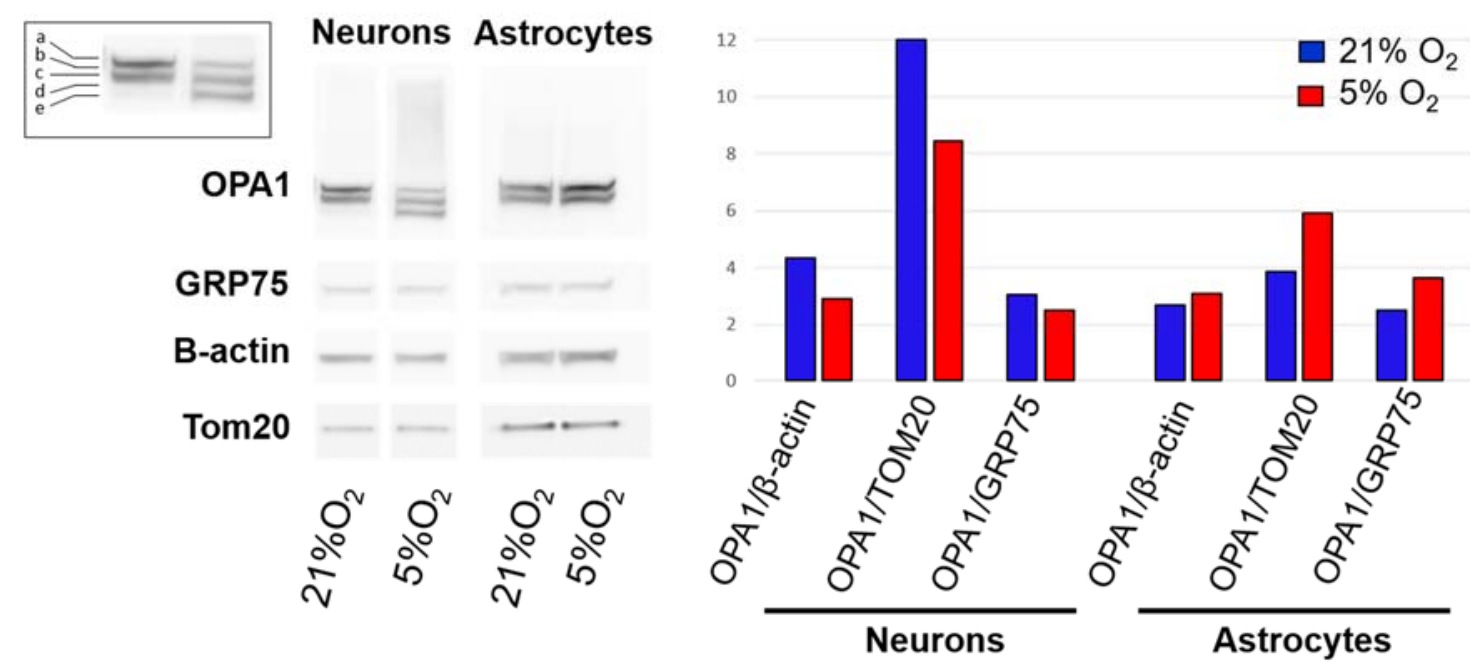

Figure 30. Opa1 protein expression in neurons and astrocytes at 5\% pO2 vs. 21\% pO2 using the Western blot of OPA1 with as housekeeping the mitochondrial genes Grp75, Tom 20 and the cytoskeletal gene $\beta$-actin. To the left emphasis on OPA1 isoforms. 
4.2.3. Structural organization of ETC in co-cultured neurons changed under physiological $\underline{\mathrm{pO}_{2}}$

We next aimed to analysis the mitochondrial complexes and super-complexes, in cocultured neurons, in order to clarify the intervention of mitochondrial micro-elements in the regulation of cell state and survival. The study revealed different alterations in mitochondrial complexes at physiological, compared to normoxic, $\mathrm{pO}_{2}$. Notably, we detected:

- An increase in free complex I, as confirmed by western blot and in gel activity assay (IGA), suggesting an increase in mROS production.

- A decreased F1 band associated to an alteration of complex V (ATP-synthase), suggesting an alteration in mitochondrial cristae. These data were confirmed by IGA.

- A shift in complex IV band, identified by western blot.

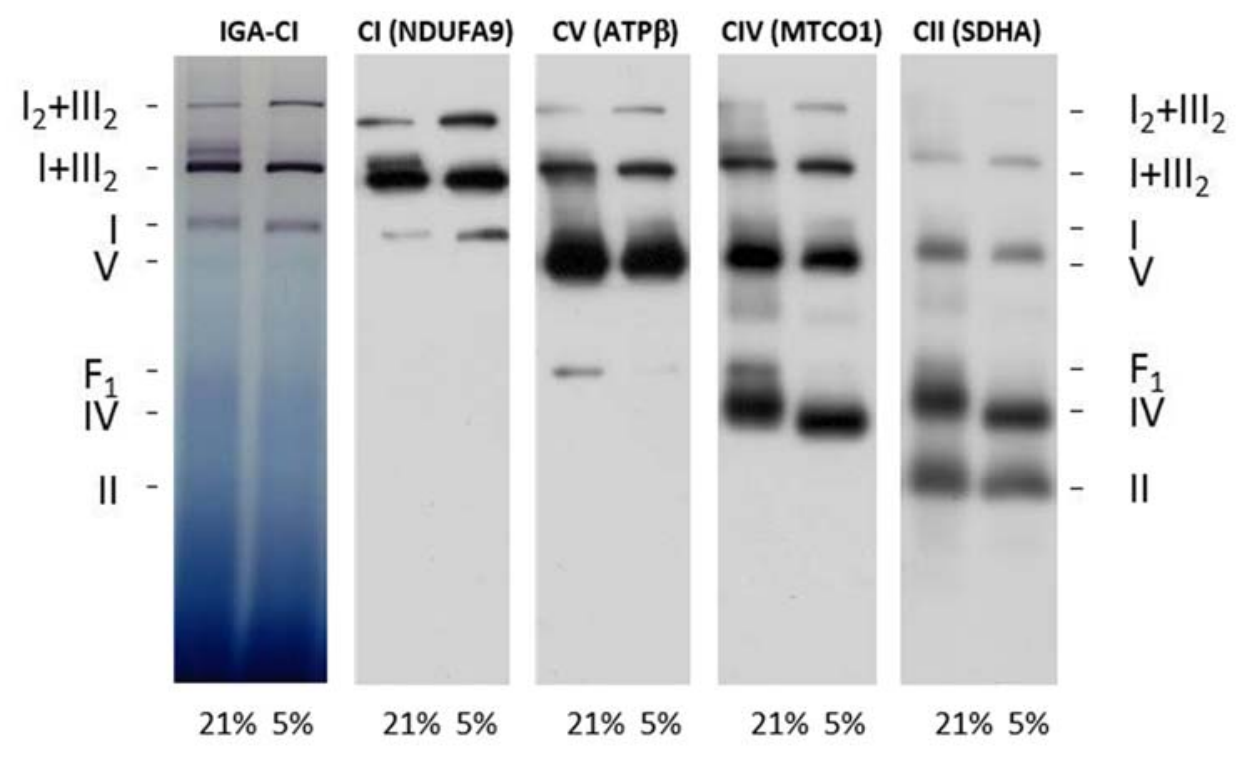

Figure 31. Effect of atmospheric pO2 on mitochondrial complexes expression and organization in co-cultured neurons. Neurons were co-cultured and incubated during 6 days at the correspondent $\mathrm{pO}_{2}$, as described in 3.2. Mitochondria were isolated as described in 2.6.1. and their extracts were run in BNGE, transferred to PVDF membranes, as described in section 2.6.2., and analysed by Western blot (see 3.5.). In gel activity tests for complexes I and V were performed as described in 2.6.3. 
4.2.4. Reduced mRNA expression of ETC-related genes, in primary cultured astrocytes and neurons, at $5 \% \mathrm{pO}_{2}$ compared to $21 \% \mathrm{pO}_{2}$

Culturing astrocytes and neurons at $5 \% \mathrm{pO}_{2}$ produced a generalized reduction in the mitochondrial complexes subunits mRNA abundances respect to $21 \% \mathrm{pO}_{2}$, as revealed by the transcriptomic analysis (fig. 32). Although, 7 mRNA (fig. 32a) and 2 mRNA transcripts (fig. 32b) were significantly overexpressed (blue solid boxes with dark frame), in astrocytes and neurons, respectively, the vast majority of them was under-expressed, with 22 and 19 transcripts being significantly reduced (red solid boxes with dark frame) in astroyctes (a) and neurons (b), respectively. Thus, the transcriptomic analysis suggests that both ETC and OxPhos were down regulated in both cell types when cultured at 5\% $\mathrm{pO}_{2}$. Interestingly, contrary to what occurred to ETC and OxPhos transcripts, most of the mRNA transcripts coding for uncoupling proteins (UCPs) were slightly, but not significantly increased, except for the neuronal UCP1, the increase of which was significant. 


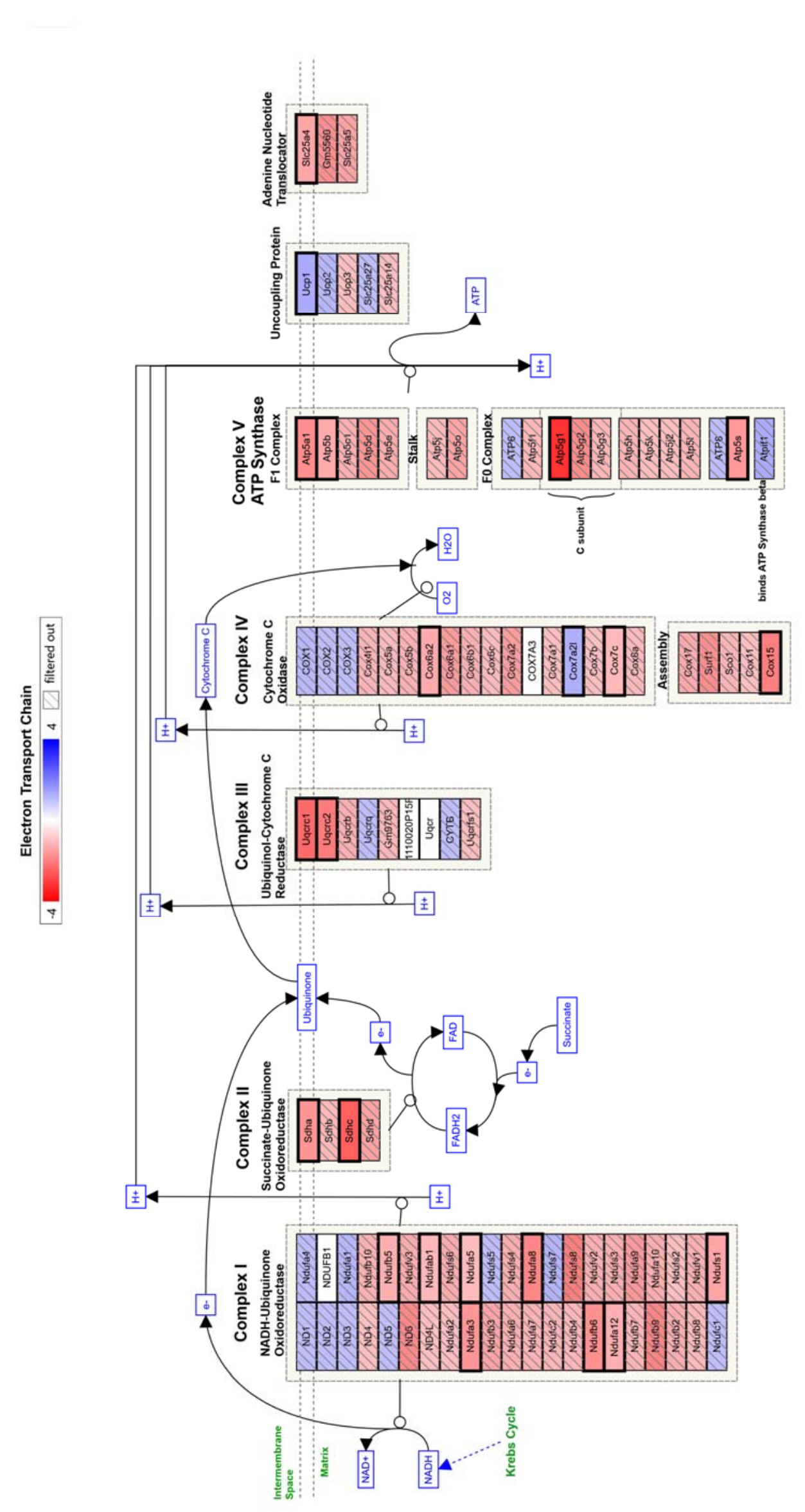

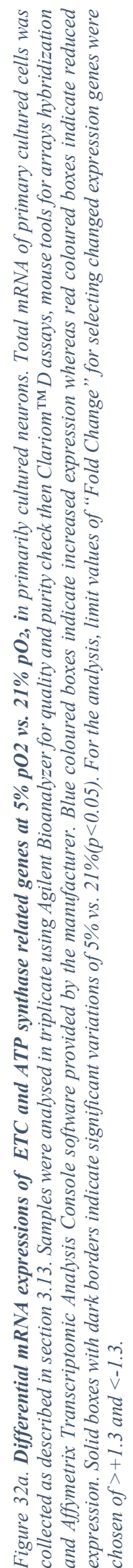

Page $\mid 56$ 


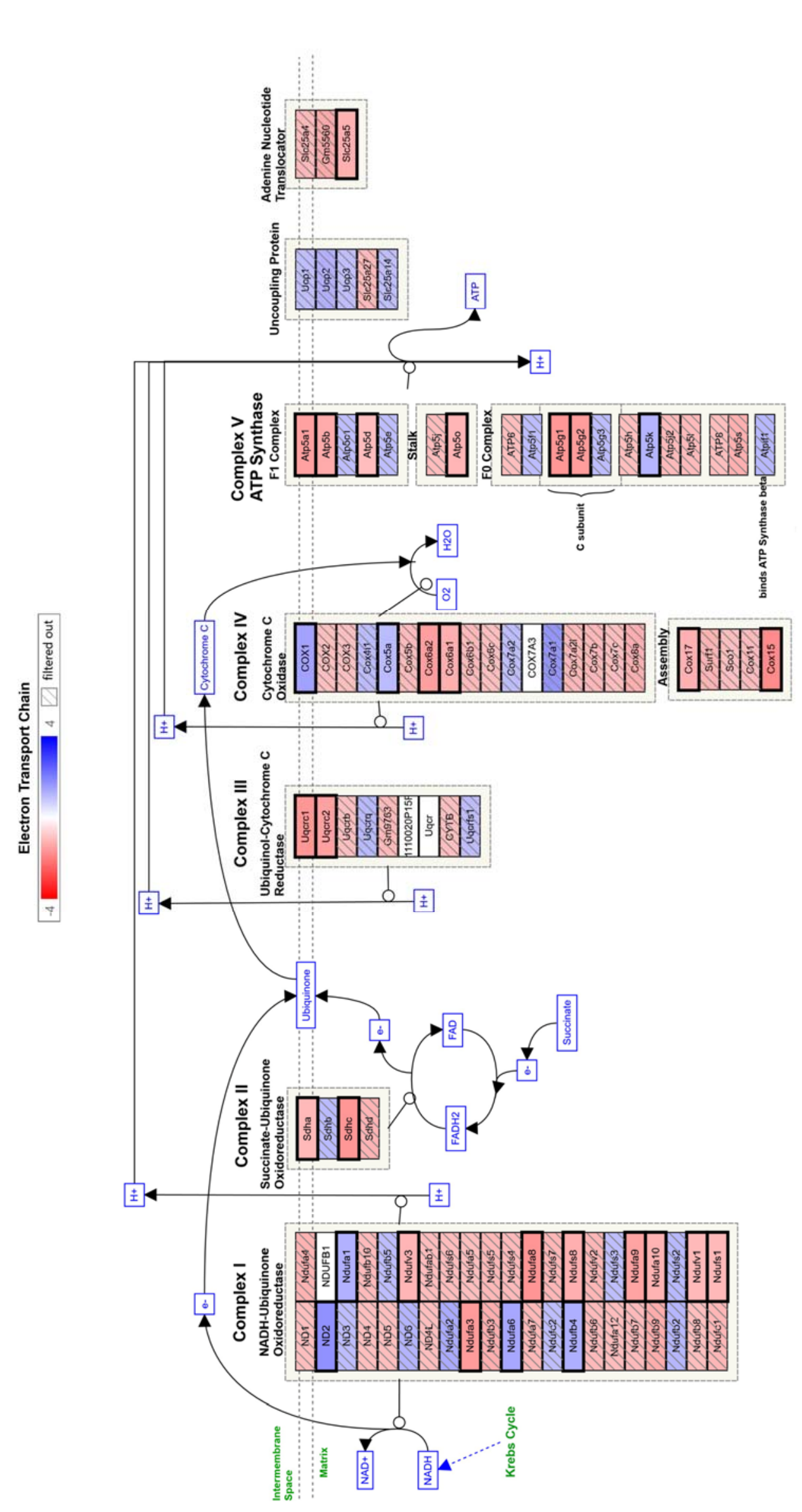

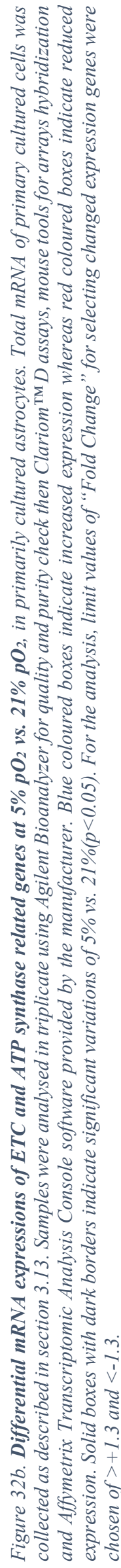

Page $\mid 57$ 


\subsection{Astrocytic or neuronal influence on the mitochondrial energy metabolism in neurons or astrocytes, respectively, at $21 \% \mathrm{pO}_{2}$ and $5 \% \mathrm{pO}_{2}$}

Since neurons and astrocytes are in intimate contact in the brain tissue, we aimed to study the effect of physiological $\mathrm{pO}_{2}$ on mitochondrial energy metabolism in co-cultures of both cell types. Both neurons and astrocytes were incubated under physiological $(5 \%)$ or canonical (21\%) $\mathrm{pO}_{2}$, separately or together (co-cultures), as described in section 2.2. Experiments were performed at day 6 of incubation "in vitro".

\subsubsection{Astrocytes improve neuronal survival in a $21 \%$ and $5 \% \mathrm{pO}_{2}$}

As seen in fig. 33, astrocytes and neurons in the same culture had effects on the survival of both cell types. The presence of astrocytes ameliorated significantly neuronal survival at both canonical (21\%) and physiological $(5 \%) \mathrm{pO}_{2}$, reducing cell apoptosis (fig. 33a). However, by the presence of neurons, astrocytes slightly reduced apoptosis when incubated at $21 \% \mathrm{pO}_{2}$, but showed a significant increase in cellular apoptosis at $5 \% \mathrm{pO}_{2}$. As shown in fig. 24, culturing cells in a $5 \% \mathrm{pO}_{2}$ improved the survival of all types of cultures, except co-cultured astrocytes, in which no significant differences were found.
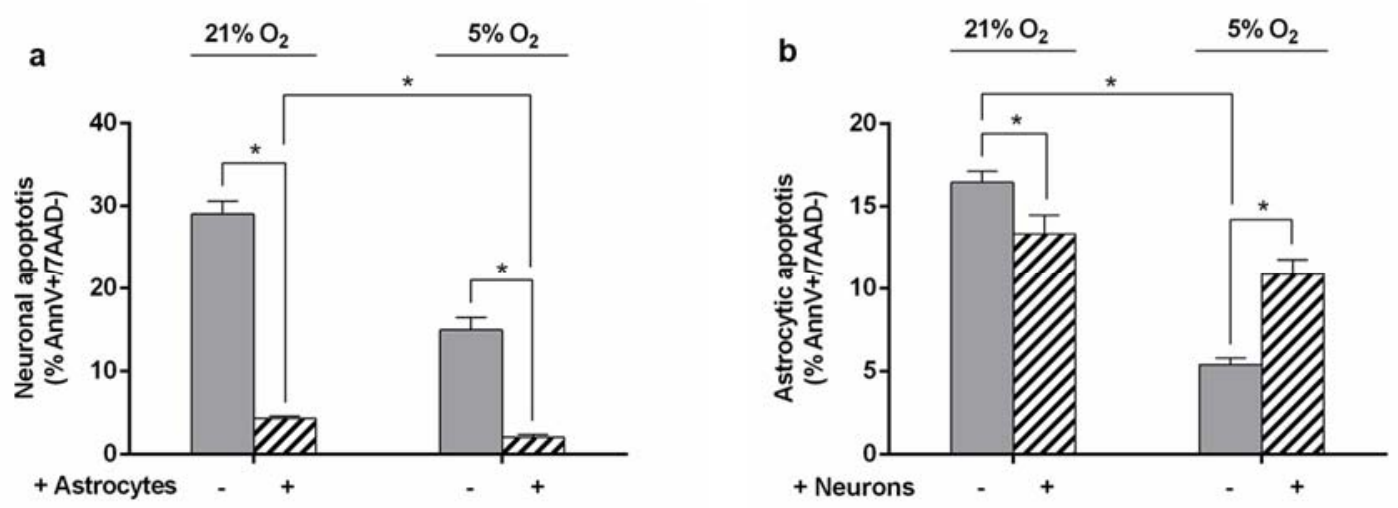

Figure 33. Effect of co-culture on apoptotic cell death of neurons (a) and astrocytes (b) at both $21 \%$ p $\mathrm{O}_{2}$ and $5 \% \mathrm{pO}_{2}$. Astrocytes and cortical neurons, were incubated during 6 days at $5 \% \mathrm{pO}_{2}$ pressure, as described in 3.2. Apoptotic cells were quantified by flow cytometry using annexin V, 7AAD tests, as described in section 3.9. Student's T-tests were performed, for the individual pair of values $\left({ }^{*} p<0.01\right)$. 
4.3.2. The presence of neurons keeps low astrocyte $\Delta \psi \mathrm{m}$ in a $5 \% \mathrm{pO}_{2}$ atmosphere, but not $\underline{\text { at } 21 \% \mathrm{pO}_{2}}$

We also analysed $\Delta \psi_{\mathrm{m}}$ in neurons and astrocytes, at 21\% $\mathrm{pO}_{2}$ and $5 \% \mathrm{pO}_{2}$, in separate and co-culture conditions using DiIC1(5) by flow cytometry as indicated in the section 2.7. Neurons and astrocytes were co-cultured for three days, as indicated in section 3.2.3. In fig. 33 we show that the presence of neurons in co-culture produced a significant reduction in $\Delta \psi_{\mathrm{m}}$ in astrocytes at the physiological $\mathrm{pO}_{2}(5 \%$; fig. $34 \mathrm{~b})$, but not at the canonical $21 \%$ $\mathrm{pO}_{2}$, compared to astrocytes cultured alone. On the contrary, the presence of astrocytes had no effect on neuronal $\Delta \psi_{\mathrm{m}}$ at both $\mathrm{pO}_{2}$.

a

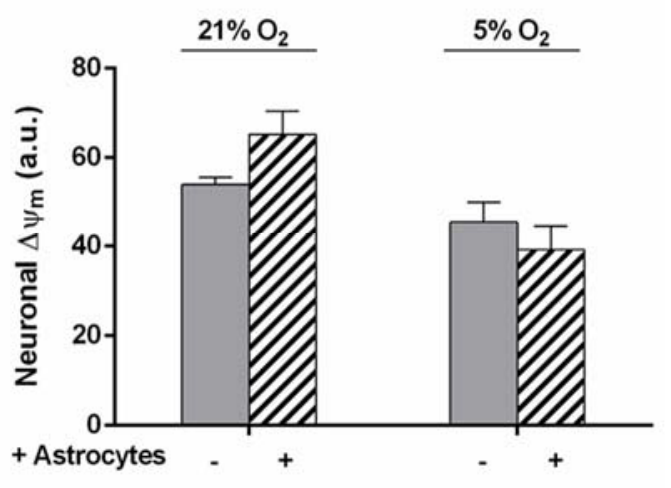

b

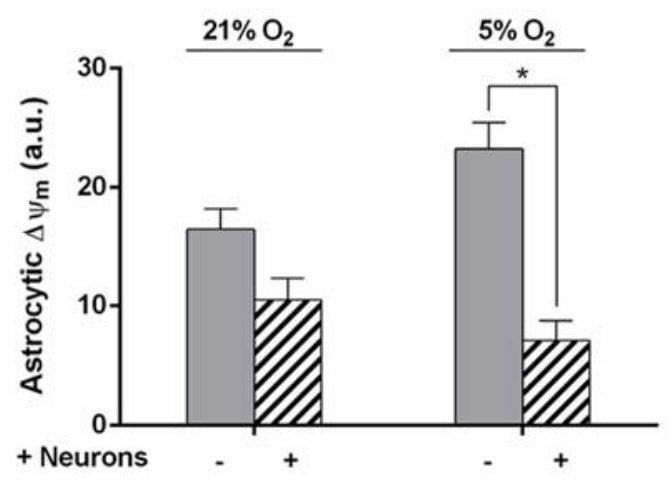

Figure 34. Effect of co-culture on $\Delta \psi_{m}$ of neurons (a) and astrocytes (b) incubated at $21 \% \mathrm{pO}_{2}$ and $5 \%$ $\mathrm{pO}_{2}$. Astrocytes and cortical neurons were incubated during 6 days at $5 \% \mathrm{pO}_{2}$ pressure, as described in 3.2. Mitochondrial membrane potential was measured by flow cytometry using DiIC1(5) and the uncoupler $C C C P$, as described in section 3.7. Student's T- tests were performed, for the individual pair of values $\left({ }^{*} p<0.01\right)$. 
4.3.3. Co-cultures of neurons and astrocytes significantly reduced the production mROS $\underline{\text { at } 5 \% \mathrm{pO}_{2}}$

Cells were co-cultured during three days before collecting samples, as indicated in section 3.2.3. $\mathrm{O}_{2}{ }^{--}$production was measured using MitoSox-Red ${ }^{\mathrm{TM}}$ by flow cytometry as described in section 2.7.1. In fig. 35b, it is shown that co-cultures lowered mROS only when cells were cultured at $5 \% \mathrm{pO}_{2}$. Under these conditions, significant decreases of $75 \%$ and $35 \%$ in the production of mROS were observed for co-cultured neurons (fig. 35a) and astrocytes (fig. 35b), respectively. Conversely, the co-culture did not affect mROS production in any cell type at $21 \% \mathrm{pO}_{2}$.
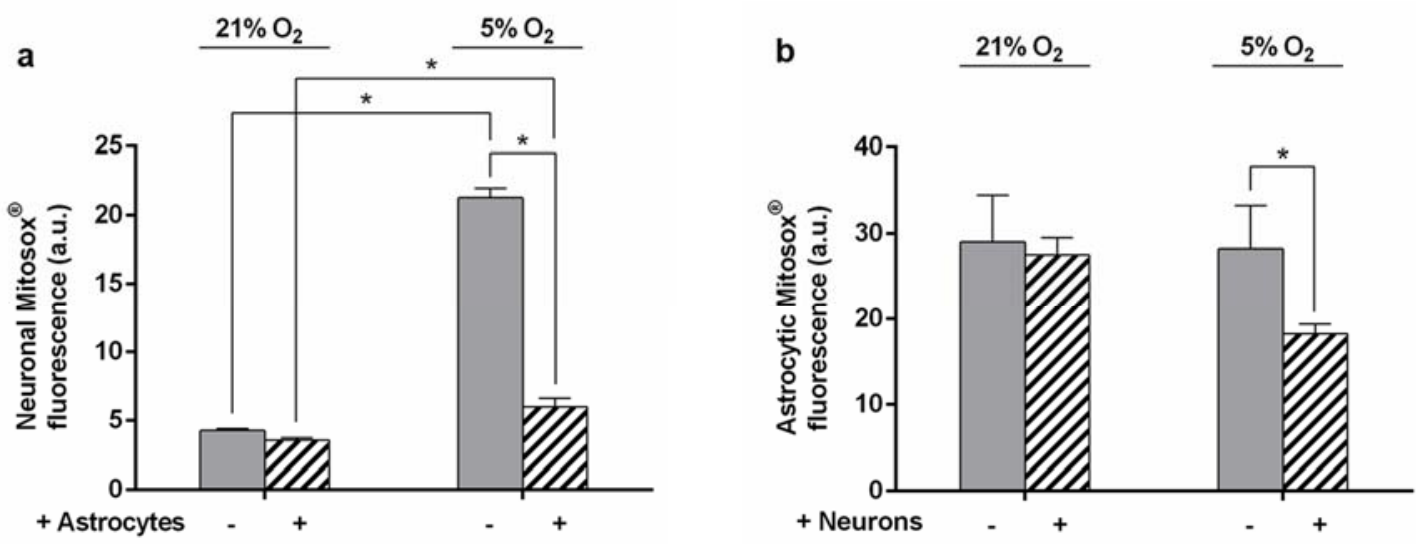

Figure 35. Effect of co-culture on the production of mROS in neurons (a) and astrocytes (b) at $5 \%$ pO $\mathrm{O}_{2}$ and $21 \% \mathrm{pO}_{2}$. Primary cell cultures, astrocytes and cortical neurons were incubated during 6 days at $5 \%$ $\mathrm{pO}_{2}$ pressure, as described in 3.2. Co-cultures were performed three days before collecting samples, as indicates section 3.2.3. Mitochondrial ROS production was tested by using the MitoSox $®$ assay in the intact cells by flow cytometry as described in section 3.8.1. Student's T-test were implemented, for the individual pair of values $(* p<0.05)$. 
4.3.4. Physiological $\mathrm{pO}_{2}$ reduced the expression of ETC and OxPhos subunits mRNA $\underline{\text { transcripts in co-cultured astrocytes and neurons }}$

Transcriptomic analysis of co-cultured neurons-astrocytes co-cultures shows that, at $5 \%$ $\mathrm{pO}_{2}$, both cell types suffered a generalized reduction in the levels of mitochondrial complexes subunits mRNA transcripts, compared to $21 \% \mathrm{pO}_{2}$ (fig. $36 \mathrm{a}$ and $\mathrm{b}$ ). As there is shown, 22 genes were significantly down-regulated in neurons and 34 in astrocytes. It is noteworthy that, under these conditions, the mRNA transcripts of all Succinate Dehydrogenase (complex II) subunits were significantly under-expressed. None of the mRNA transcripts related to the ETC and OxPhos pathways was significantly increased in any of the cell types. 

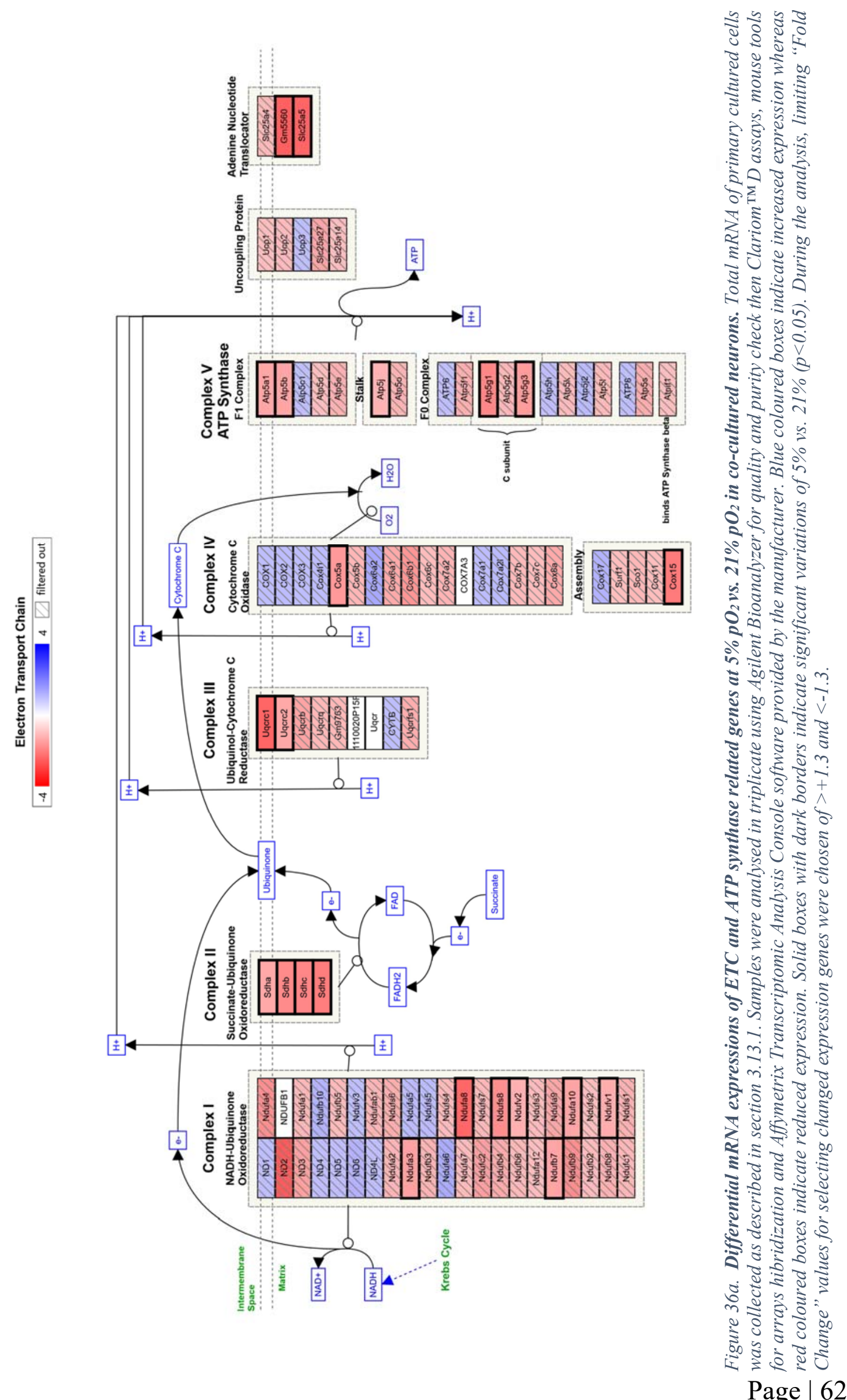


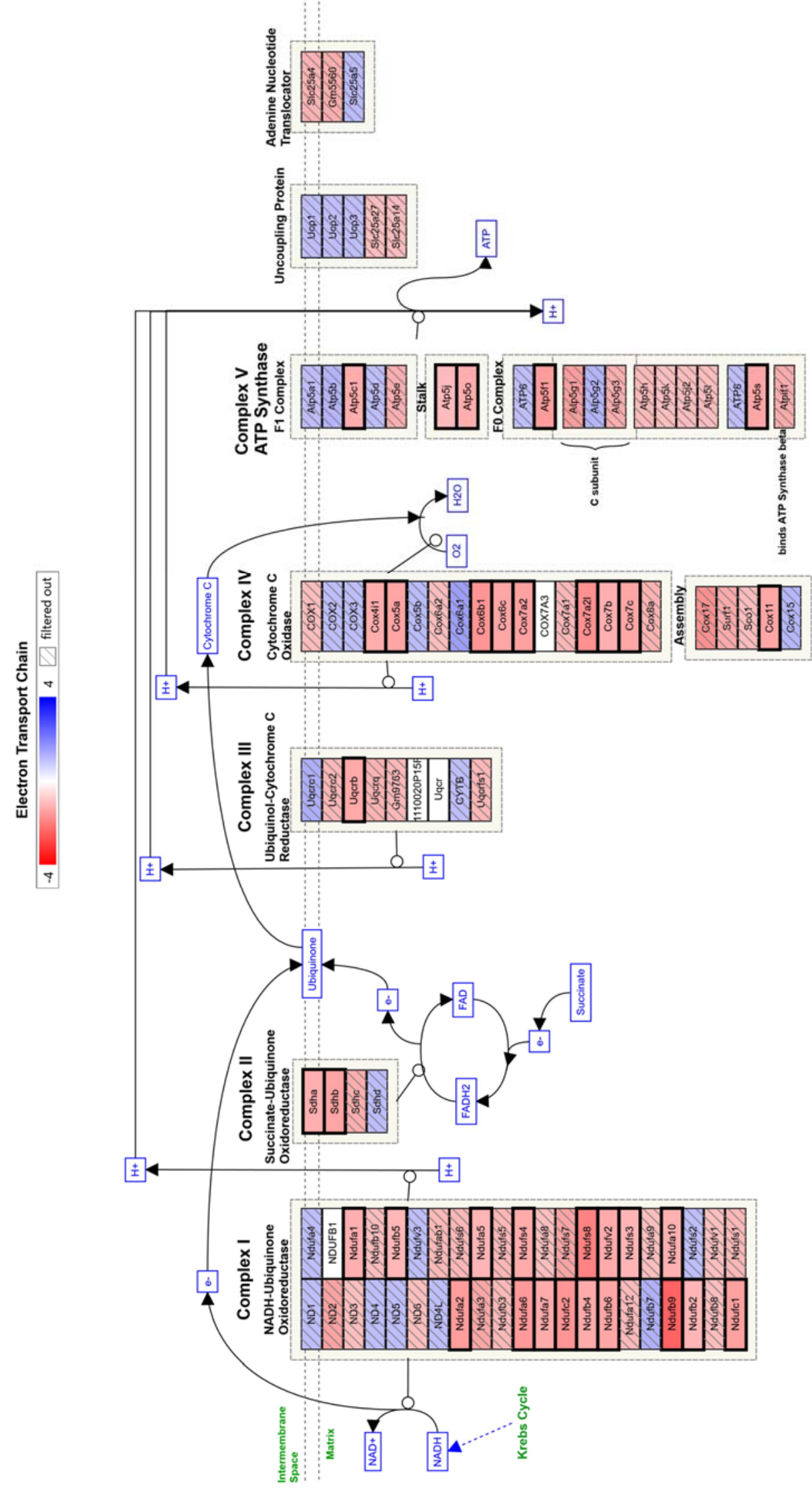

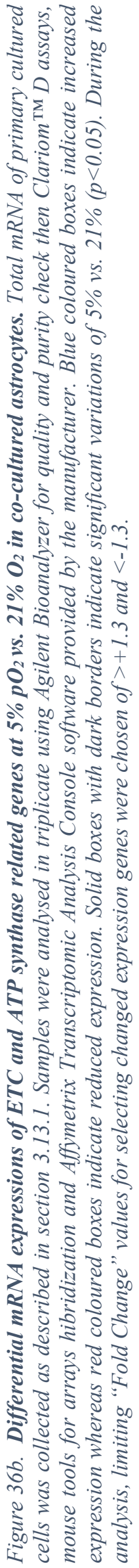

Page $\mid 63$ 


\subsection{Effect of physiological $\mathrm{pO}_{2}$ on glucose metabolism in cultured neurons and astrocytes}

4.4.1. Physiological $\mathrm{pO}_{2}$ increases glucose consumption and lactate production in cultured neurons and astrocytes

Once observed the effect of $\mathrm{pO}_{2}$ on the expression of ETC and OxPhos related mRNA transcripts, suggesting energy metabolism affection, we next aimed to elucidate if glucose metabolism of neurons and astrocytes could also be modulated by the reduction in the oxygen partial pressure. Thus, we analysed glucose consumption and lactate production, both in separate and in co-cultured astrocytes and neurons, either at physiological $\left(5 \% \mathrm{pO}_{2}\right)$ or at canonical $\left(21 \% \mathrm{pO}_{2}\right)$ atmospheres. As it can be seen in fig. $37 \mathrm{a}$, glucose consumption significantly increased, by about 2-fold, at physiological 5\% $\mathrm{pO}_{2}$ when compared to the canonical $21 \% \mathrm{pO}_{2}$, in neurons and in astrocytes cultured separately, as well as in co-culture.

In parallel with the increased glucose consumption, lactate production was also significantly increased when cells were incubated at $5 \% \mathrm{pO}_{2}$ respect to $21 \% \mathrm{pO}_{2}$ (Fig. 37b). In all cases, the proportion of glucose transformed into lactate was about 40-50\%, without significant differences between the different cell types and cultures.
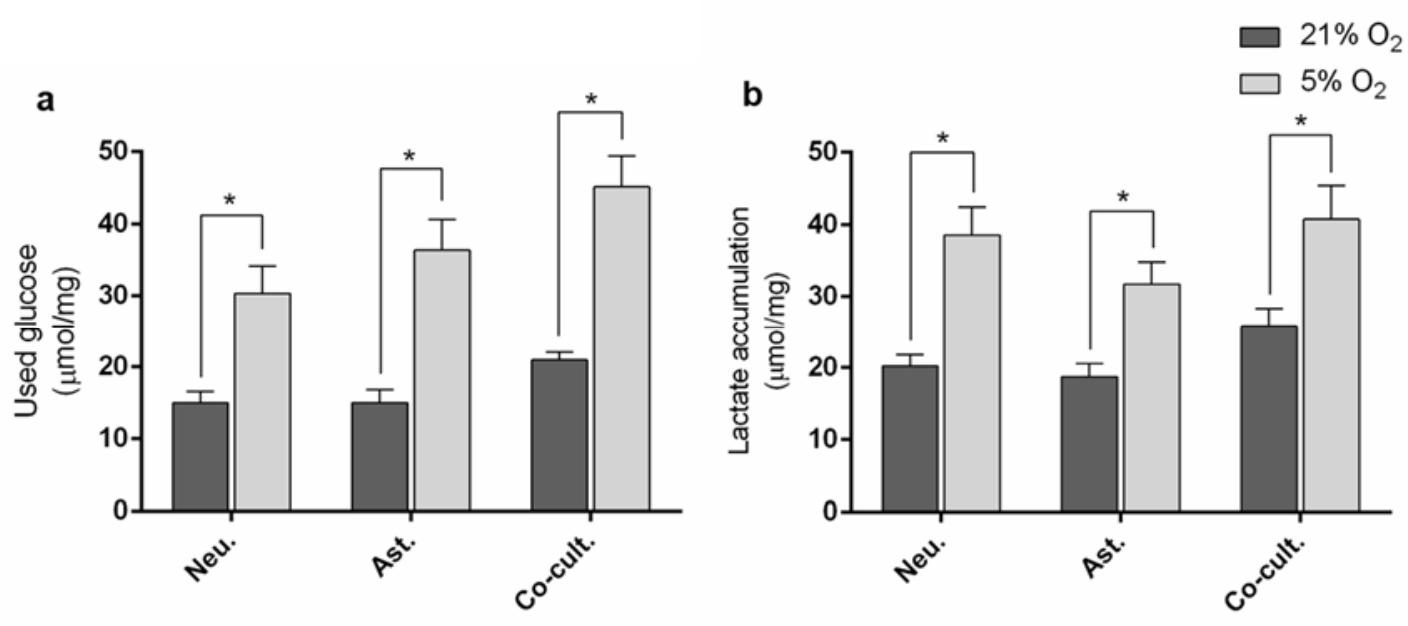

Figure 37. Effect of atmospheric 5\% $\mathrm{pO}_{2}$ on the media glucose consumption and media lactate accmulution by neurons, astrocytes and co-cultured cells. Measurements of media glucose and lactate concentrations were done at 24 h of incubation starting from day 6 of culture, after a media change. Neurons and astrocytes were cultured as described in 3.2. D-glucose and L-lactate were determined spectrophotometrically as described in 3.10.2. and 3.10.3. respectively. Student's T-tests were performed, for the individual pair of values $(* p<0.05)$. 


\subsubsection{Physiological $\mathrm{pO}_{2}(5 \%)$ induced the expression of glycolysis-related mRNA}

\section{$\underline{\text { transcripts in cultured neurons and astrocytes }}$}

In agreement with the increased glucose consumption and lactate release, the transcriptomic analysis shows generalized increases in glycolytic enzymes mRNA transcripts, both in neurons and in astrocytes, when cells were cultured at physiological $\mathrm{pO}_{2}$ $(5 \%)$ respect to the canonical $\mathrm{pO}_{2}(21 \%$; fig. $38 \mathrm{a}$ and $38 \mathrm{~b})$. As shown in fig. $38 \mathrm{a}$, mRNA expression of at least one isoform of each glycolytic enzyme (except Pyruvate Kinase and Glyceraldehyde Phosphate Dehydrogenase) were significantly increased in neurons. Noteworthy, the Slc2a1 mRNA, which encodes for the glucose transporter GLUT1, was increased by 27 times $(p<0.0001)$. Likewise, transcriptomic analysis revealed that the glycolytic activator protein PFKFB3 mRNA was also increased by 4.2 -fold $(\mathrm{p}<0.0005)$ under these conditions.

Astrocytes cultured at $5 \% \mathrm{pO}_{2}$ also showed an increased expression of glycolytic mRNA transcripts, but in a less extension than in neurons (fig. 38b). Thus, none of glucose transporters mRNA transcripts, was overexpressed, and the maximum fold-change was 4.6 $(\mathrm{p}<0.0001)$ for the $\mathrm{L}$ isoform of Phosphofructose Kinase 1 (PFK1-L). In this case, the glycolytic activator protein PFKFB3 mRNA expression was lightly increased (by a 1.35fold, $\mathrm{p}<0.01$ ), compared to cells incubated at $21 \% \mathrm{pO}_{2}$. 


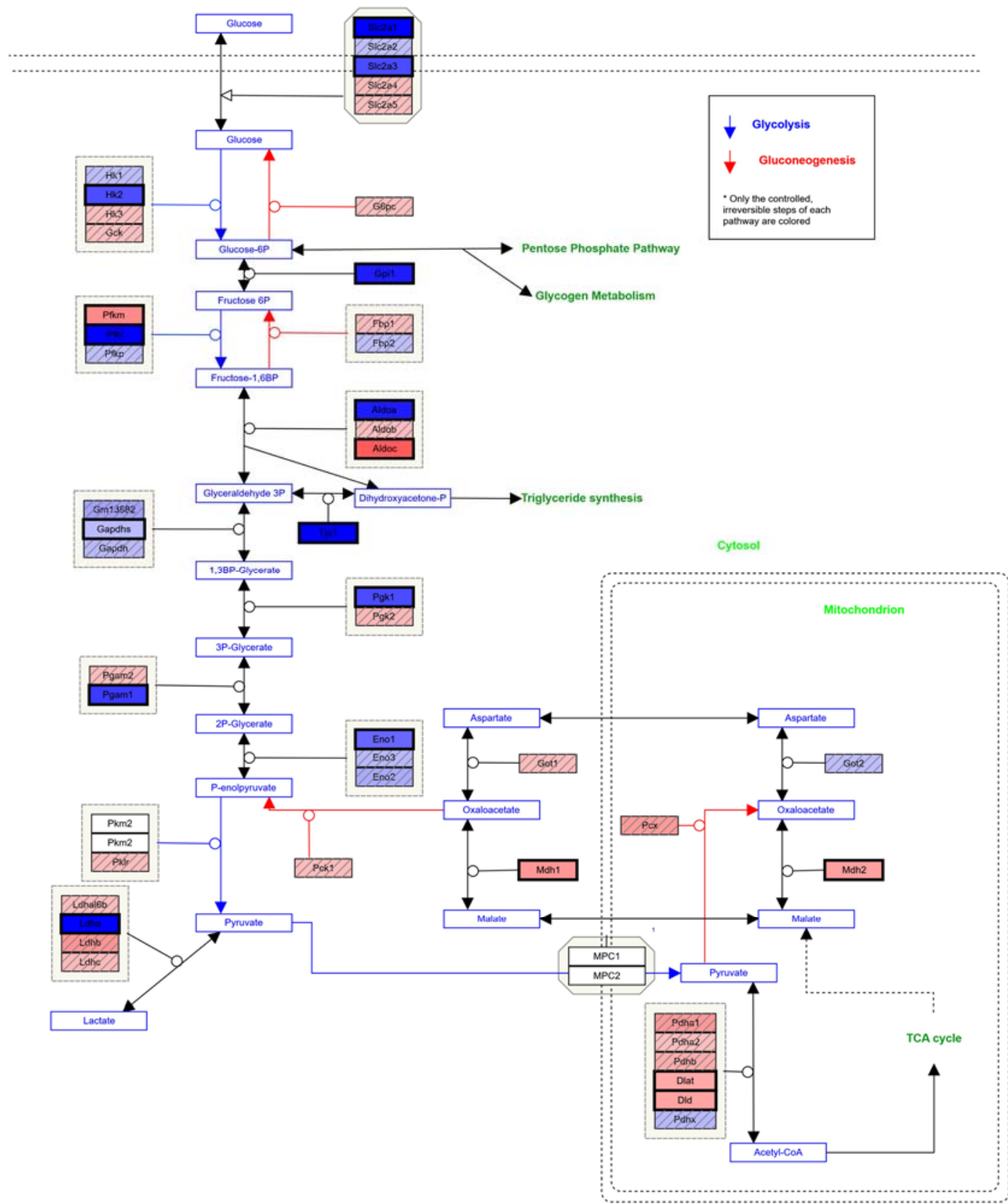

Figure 38a. Differential mRNA expressions of glycolysis related genes in neurons, cultured at $5 \% \mathrm{pO}_{2}$ vs. $21 \% \mathrm{pO}_{2}$. Samples were analysed in triplicate using Agilent Bioanalyzer for quality and purity check then Clariom $^{\mathrm{TM}}$ D assays, mouse tools for arrays hybridization and Affymetrix Transcriptomic Analysis Console software provided by the manufacturer. Blue coloured boxes indicate increased expression whereas red coloured boxes indicate reduced expression. Solid boxes with dark borders indicate significant variations of $5 \%$ vs. $21 \%(p<0.05)$. During the analysis, limit values of "Fold Change" for selecting changed expression genes were chosen of $>+1.3$ and $<-1.3$. 


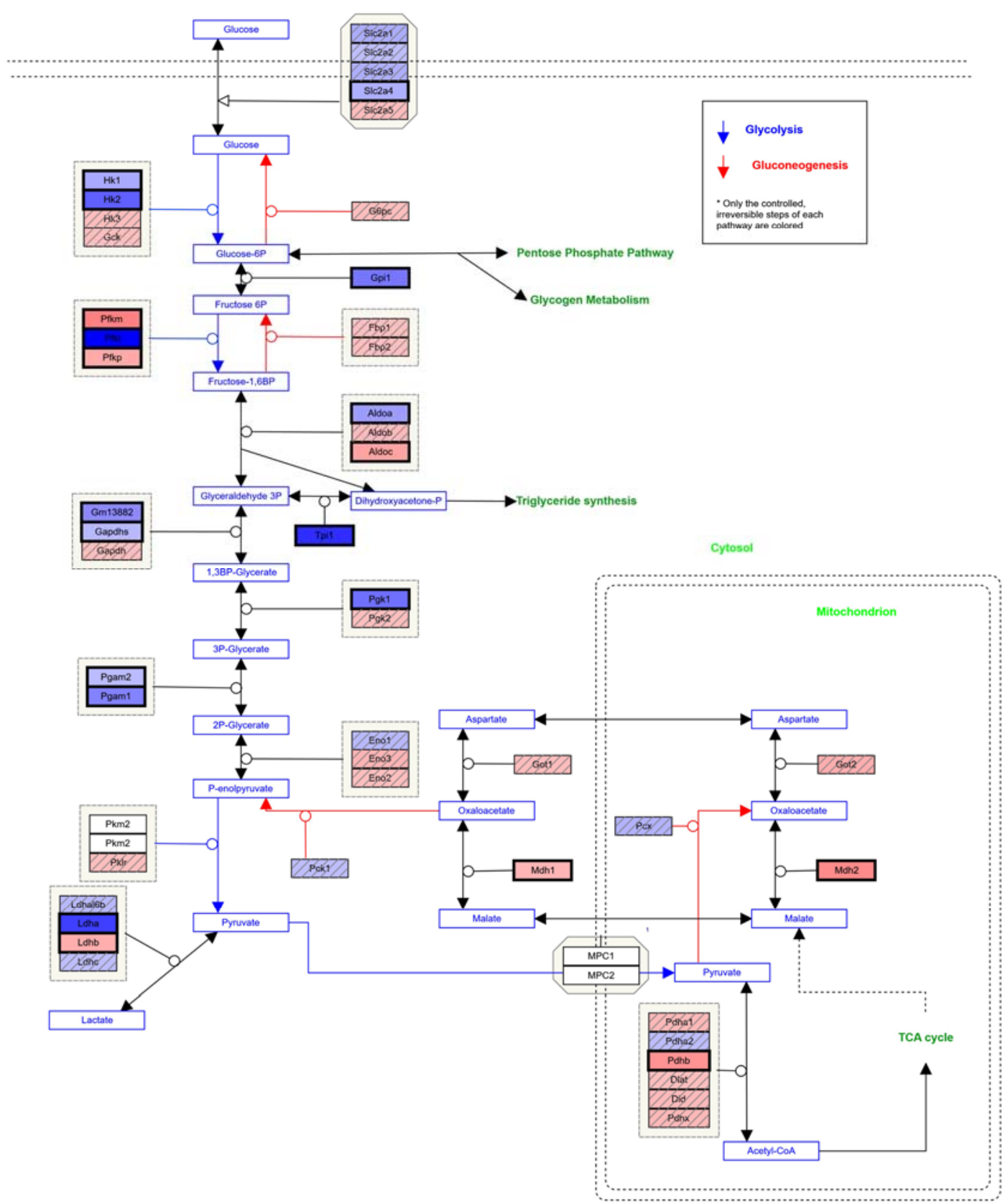

Figure 38b. Differential mRNA expressions of glycolysis related genes in astrocytes, cultured at 5\% p ${ }_{2}$ vs. 21\% $\mathrm{pO}_{2}$. Samples were analysed in triplicate using Agilent Bioanalyzer for quality and purity check then Clariom ${ }^{\mathrm{TM}} \mathrm{D}$ assays, mouse tools for arrays hybridization and Affymetrix Transcriptomic Analysis Console software provided by the manufacturer. Blue coloured boxes indicate increased expression whereas red coloured boxes indicate reduced expression. Solid boxes with dark borders indicate significant variations of $5 \%$ vs. 21\% $(p<0.05)$. During the analysis, limit values of "Fold Change" for selecting changed expression genes were chosen of $>+1.3$ and $<-1.3$. 
4.4.3. Physiological $\mathrm{pO}_{2}$ increased glycolytic rates in neurons and astrocytes, as compared with the established $21 \% \mathrm{pO}_{2}$

Once observed the changes in glucose consumption, lactate accumulation and in the expression of glycolytic mRNAs, we decided to test if such results correlated with the glycolysis pathway activity. Thus, we sought to analyse the glycolytic rates of neurons and astrocytes at physiological $\mathrm{pO}_{2}(5 \%)$ compared to the canonical $\mathrm{pO}_{2}(21 \%)$. Glycolytic rates were measured as the formation of ${ }^{3} \mathrm{H}_{2} \mathrm{O}$ from $\left(3-{ }^{3} \mathrm{H}\right)$-Glucose as it has been described in section 3.11.1. As shown in fig. 39, glycolytic rates were increased about two fold as $\mathrm{pO}_{2}$ drops until a partial pressure of 5\%, for both kind of cells. Astrocytes exhibited 3-fold more glycolytic activity than neurons $(\mathrm{p}<0.01)$, regardless of the $\mathrm{pO}_{2}$.
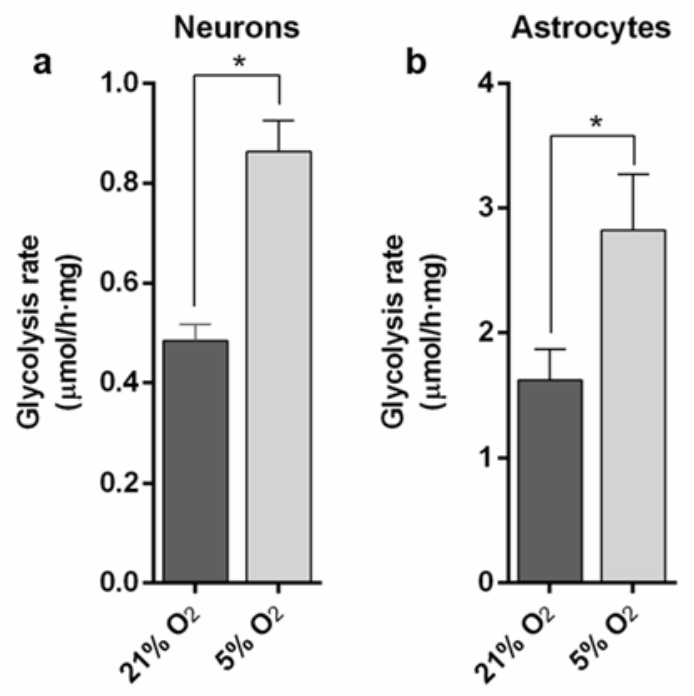

Figure 39. Influence of the $\mathrm{pO}_{2}$ on the glycolytic rate of neurons and astrocytes in primary cultures. Primary cell cultures, astrocytes or cortical neurons, were incubated during 6 days at 5\% $\mathrm{pO}_{2}$ pressure, as described in 3.11.1. and co-cultured at the same pressure, as described in 3.11.2. Glycolysis rate was determined measuring the production of ${ }^{3} \mathrm{H}_{2} \mathrm{O}$ from $\mathrm{D}$ $\left[3-{ }^{3} \mathrm{H}\right]$ glucose by the aldolase catalysed reaction. Student's T-tests were performed for the statistical analysis for each cell type $\left({ }^{*} p<0.05\right)$. 
4.4.4. Physiological $\mathrm{pO}_{2}(5 \%)$ induced the expression of glycolysis-related protein mRNA transcripts in co-cultured neurons and astrocytes

In a previous section (fig. 37) we showed that neuron-astrocyte co-cultures increased the consumption of glucose and the accumulation of lactate in the medium, when incubated at physiological oxygen partial pressures (i.e. $5 \% \mathrm{pO}_{2}$ ), respect to incubation at $21 \% \mathrm{pO}_{2}$. However, the transcriptomic analysis of these co-cultured cells revealed different transcriptional response in neurons and astrocytes. Therefore, co-cultured neurons increased the expression of almost all glycolytic genes (fig. 40a), including glucose transporters GLUT1 (36.5 fold; $\mathrm{p}<0.001$ ) and GLUT3 (8.8 fold; $\mathrm{p}<0.001$ ), resembling the response described for neurons alone (see section 4.3.6; fig 38a). Conversely, none of the glycolytic genes were significantly altered in co-cultured astrocytes when they were incubated at 5\% $\mathrm{pO}_{2}$ (fig. 40b). Moreover, although there were no significant changes, the overall red tone in the color-coded scheme seems to indicate a tendency towards glycolysis down-regulation in co-cultured astrocytes at $5 \% \mathrm{pO}_{2}$. 


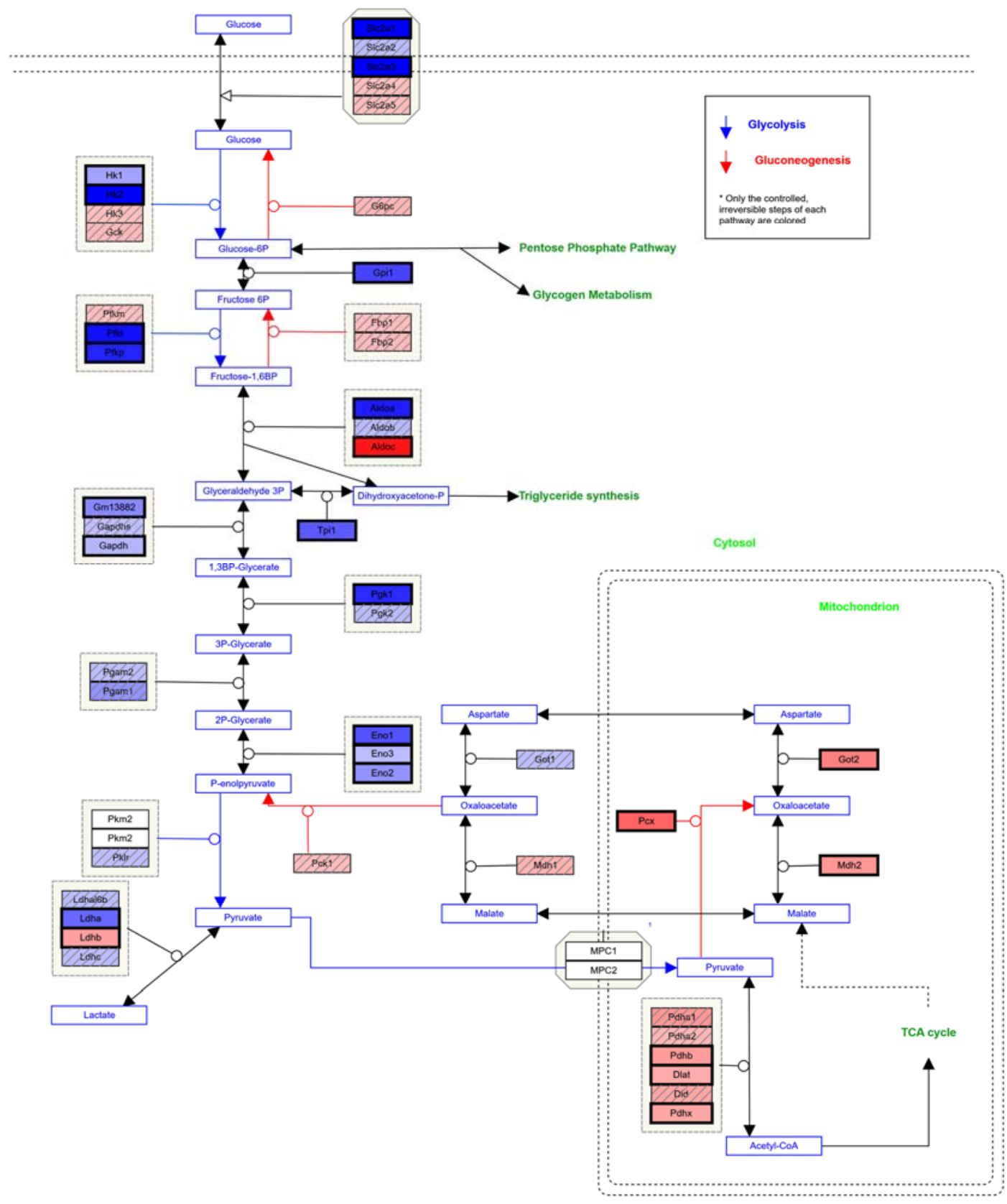

Figure 40a. Differential mRNA expressions of glycolysis related genes in co-cultured neurons at $5 \%$ p $\mathrm{O}_{2}$ vs. $21 \% \mathrm{pO}_{2}$. Samples were analysed in triplicate using Agilent Bioanalyzer for quality and purity check then Clariom $^{\mathrm{TM}} D$ assays, mouse tools for arrays hibridization and Affymetrix Transcriptomic Analysis Console software provided by the manufacturer. Blue coloured boxes indicate increased expression whereas red coloured boxes indicate reduced expression. Solid boxes with dark borders indicate significant variations of $5 \%$ vs. 21\% ( $<$ <0.05). During the analysis, limit values of "Fold Change" for selecting changed expression genes were chosen of $>+1.3$ and $<-1.3$. 


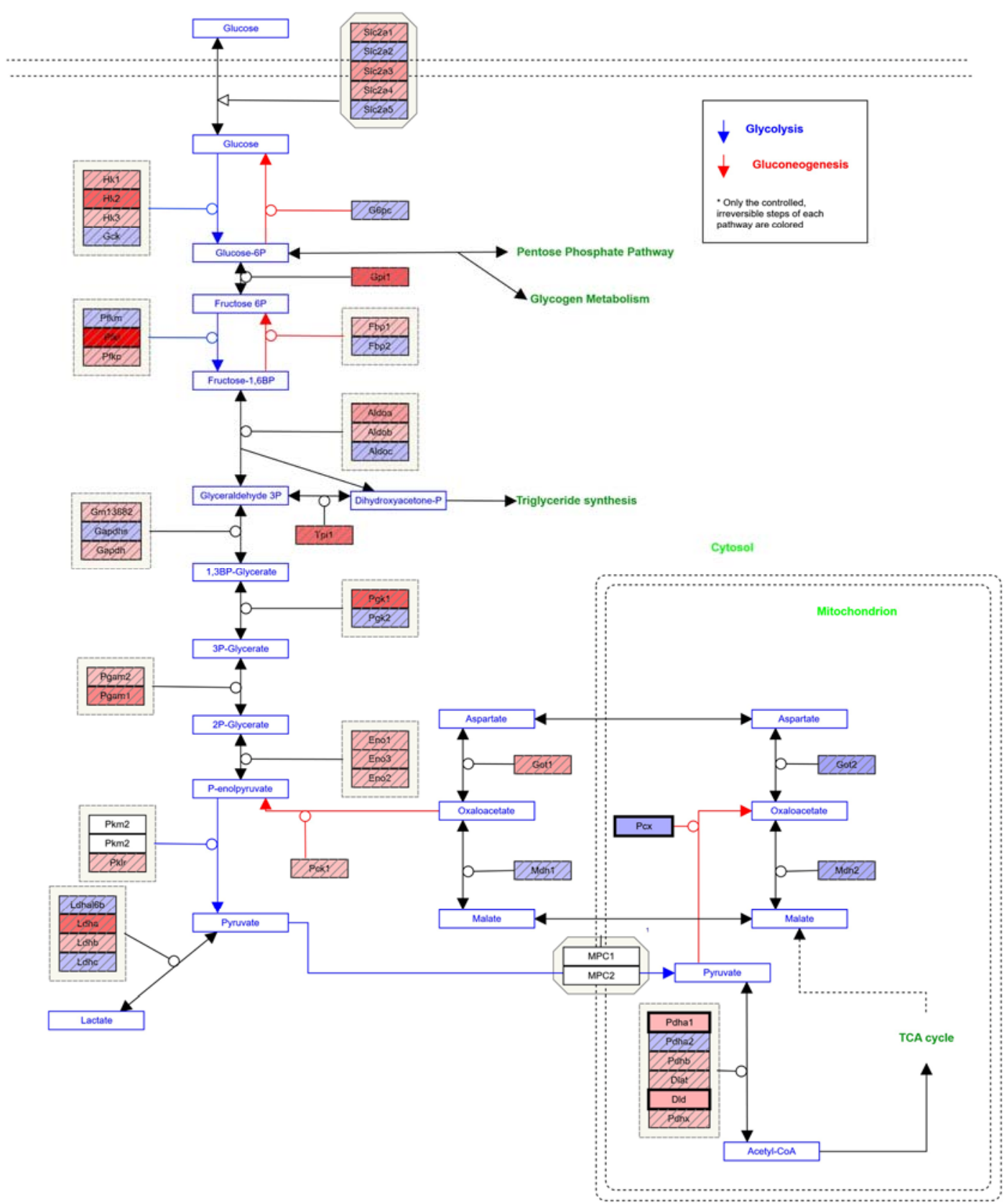

Figure 40b. Differential mRNA expressions of glycolysis related genes in co-cultured astrocytes at $5 \% \mathrm{pO} \mathrm{O}_{2}$ vs. 21\% $\mathrm{pO}_{2 .}$. Samples were analysed in triplicate using Agilent Bioanalyzer for quality and purity check then Clariom $^{\mathrm{TM}} \mathrm{D}$ assays, mouse tools for arrays hibridization and Affymetrix Transcriptomic Analysis Console software provided by the manufacturer. Blue coloured boxes indicate increased expression whereas red coloured boxes indicate reduced expression. Solid boxes with dark borders indicate significant variations of $5 \%$ vs. $21 \%(p<0.05)$. During the analysis, limit values of "Fold Change" for selecting changed expression genes were chosen of $>+1.3$ and $<-1.3$. 
4.4.5. Reduction of $\mathrm{O}_{2}$ to physiological values increases glycolysis in co-cultured neurons but not in co-cultured astrocytes

Given the observed effect of physiological $\mathrm{pO}_{2}$ on the glycolytic enzymes mRNA abundances of co-cultured neurons and astrocytes (previous section), we decided to test the effect of these culture conditions on the glycolytic rates in both types of cells. Thus, we determined the production of ${ }^{3} \mathrm{H}_{2} \mathrm{O}$ from D-[3- $\left.{ }^{3} \mathrm{H}\right]$ glucose, by aldolase-catalysed reaction as described in section 2.10. As it is shown in fig. 41a, neurons showed a significant increase of the glycolytic flux when incubated in a $5 \% \mathrm{pO}_{2}$. Under these culture conditions, astrocytic glycolysis was unchanged. As shown in this figure, astrocytes had about four times higher glycolytic rate than neurons.

a Co-cultured Neurons

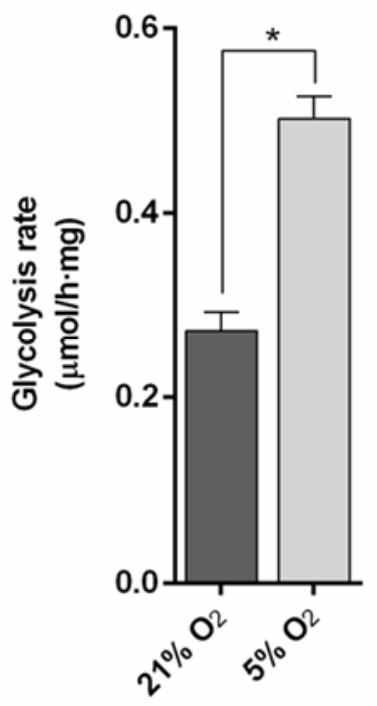

b Co-cultured Astrocytes

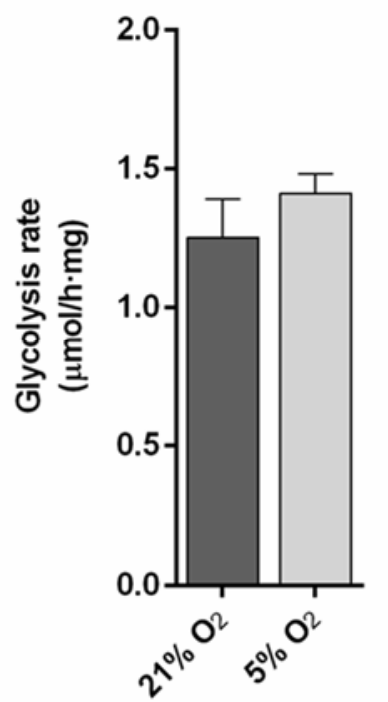

Figure 41. Influence of $\mathrm{pO}_{2}$ on the glycolytic rate of neurons (a) and astrocytes (b) in primary cultures. Primary cell cultures, astrocytes or cortical neurons, were incubated during 6 days in a 5\% pO2 or 21\% pO2 atmosphere, as described in 3.11.1. Glycolysis rate was determined measuring the production of $3 \mathrm{H} 2 \mathrm{O}$ from $\mathrm{D}-[3-3 \mathrm{H}]$ glucose by the aldolase catalysed reaction. A Student's T-test was performed for the statistical analysis for each cell type $(*=p<0.05)$. 


\subsubsection{Physiological $\mathrm{pO}_{2}$ increase the expression of Hexose Kinase II (HKII) protein in}

\section{$\underline{\text { co-cultured neurons }}$}

HKII, catalyzes the phosphorylation of glucose to produce glucose-6-phosphate, i.e., the first step of the glycolytic cascade. HKII was one of the glycolytic genes whose mRNA increased according to the transcriptomic analyis in section 4.4.4. Here, we analysed the protein expression of HKII by western blot in co-cultured neurons, under physiological and in normoxic oxygen pressures, as a representative sample of glycolytic genes. As shown in fig. 42 , HKII protein expression significantly increased at $5 \%$ compared to $21 \% \mathrm{pO}_{2}$, in good consistency with the increased rate of glycolysis as previously shown.
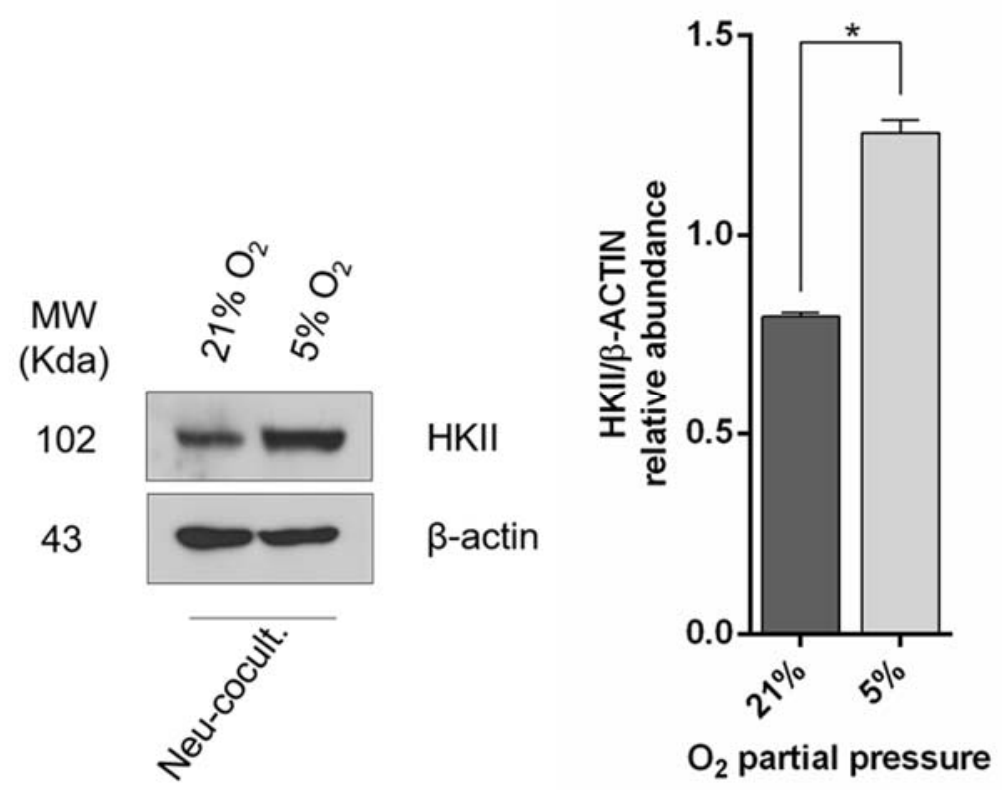

Figure 42. Effect of physiological $\mathrm{pO}_{2}$ on $\mathrm{HKII}$ protein expression in cocultured neurons. Neurons were co-cultured as indicated in 3.2.3. at the correspondent $\mathrm{O}_{2}$ pressure. Cellular extracts were prepared as described in 3.5. previous to Western blot analysis. A Student's T-test was performed for statistical analysis ( ${ }^{*} p<0.05$ for at least three different experiments). 


\subsubsection{Reduced expression and activity levels of HIF-1 $\alpha$ in co-cultured neurons at}

physiological $\mathrm{pO}_{2}$

It is well known that HKII is one of the HIF1 transactivated genes (see table 2 in section 1.1.5.6). In order to confirm HIF1 involvement in the observed induction of HKII, we analysed the nuclear and cytoplasmic levels of HIF-1 $\alpha$ protein subunit, in co-cultured neurons chronically incubated under physiological $\mathrm{pO}_{2}(5 \%)$. We also assessed the transcriptional activity of HIF1 through the expression of the luciferase (Luc) gene driven by the Hypoxia Responsive Element (HRE).

As shown in fig. 43a, co-cultured neurons chronically (6 days) incubated at physiological $\mathrm{pO}_{2}(5 \%)$ reduced HIF-1 $\alpha$ nuclear content by $50 \%$ respect to the cells incubated at the canonical $21 \% \mathrm{pO}_{2}$. Such a reduction was confirmed by the expression of Luc protein in co-cultured neurons that were transfected during 24 hours with a plasmid containing the Luc gene driven by HRE. Thus, in these experiments, we observed an $85 \%$ reduction of Luc activity (fig. 43b), indicating the low nuclear activity of HIF-1 $\alpha$ under the above mentioned experimental conditions.

a)

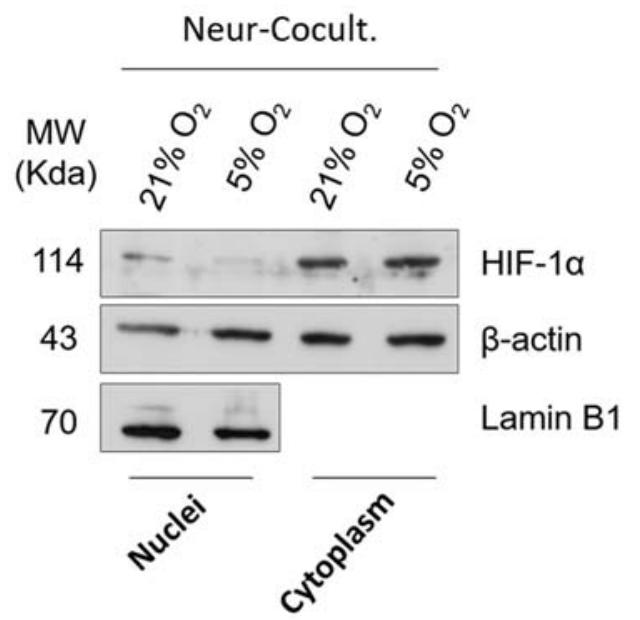

b)

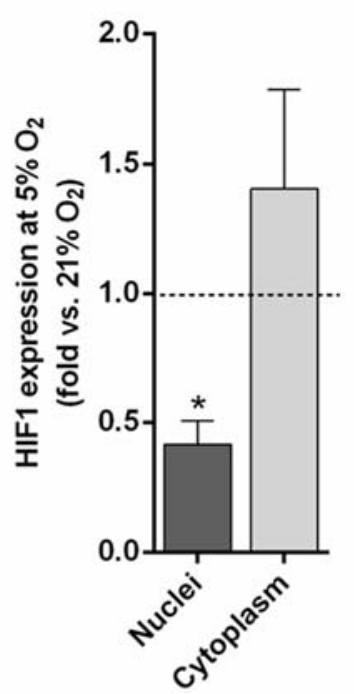

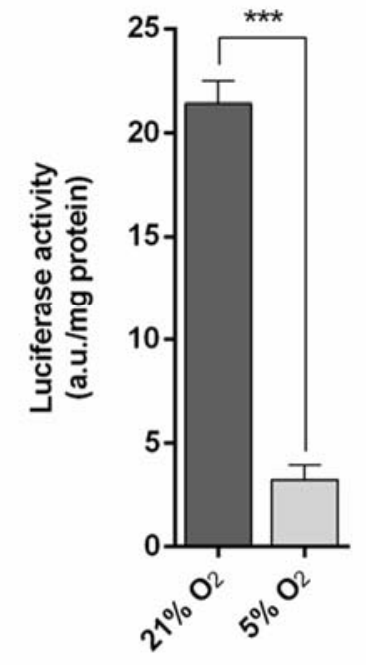

Figure 43. HIF-1 a protein expression and activity in co-cultured neurons at 5\% vs. 21\% p $\mathrm{O}_{2}$. (a) Western blots of HIF-1 $\alpha$ were performed as described in 3.5. Cytoskeletal $\beta$-actin and Lamin B1were used as loading control for cytoplasm and nuclei respectively. A Student's T-test was performed for statistical differences $\left({ }^{*} p<0.05\right.$ for at least three different experiments. 


\subsubsection{Physiological $\mathrm{pO}_{2}$ reduces AMPK and $\mathrm{pAMPK}$ protein expression in co-cultured}

$\underline{\text { neurons }}$

As stated in section 1.1.5.6., there seems to be an interconnection between HIF-1 $\alpha$ and AMPK activities. Given that, glycolysis is also regulated by the AMPK activity through the modulation of the glycolytic regulator PFKFB3 (see section 1.3.2), we decided to analyse the amounts of AMPK and phosphorylated AMPK proteins, both in physiological $(5 \%)$ and in normoxic $(21 \%) \mathrm{pO}_{2}$.

As shown in fig. $44 \mathrm{a}$, at $5 \% \mathrm{pO}_{2}$, co-cultured neurons showed a significant decrease in AMPK protein expression compared to $21 \% \mathrm{p} \mathrm{O}_{2}$. Furthermore, as the active form of AMPK is the phosphorylated one, we determined the ratio of phosphorylated/total AMPK (pAMPK/AMPK). This ratio was significantly decreased in co-cultured neurons in the presence of physiological $\mathrm{pO}_{2}(5 \%)$ respect to those cells co-cultured in normoxic conditions $\left(21 \% \mathrm{pO}_{2}\right.$; fig. $\left.44 \mathrm{~b}\right)$. These results indicate a reduced activity of the AMP dependent protein kinase under physiological oxygen partial pressures, and therefore they suggest that energy requirements of co-cultured neurons are fulfilled at the low physiological $\mathrm{pO}_{2}$.
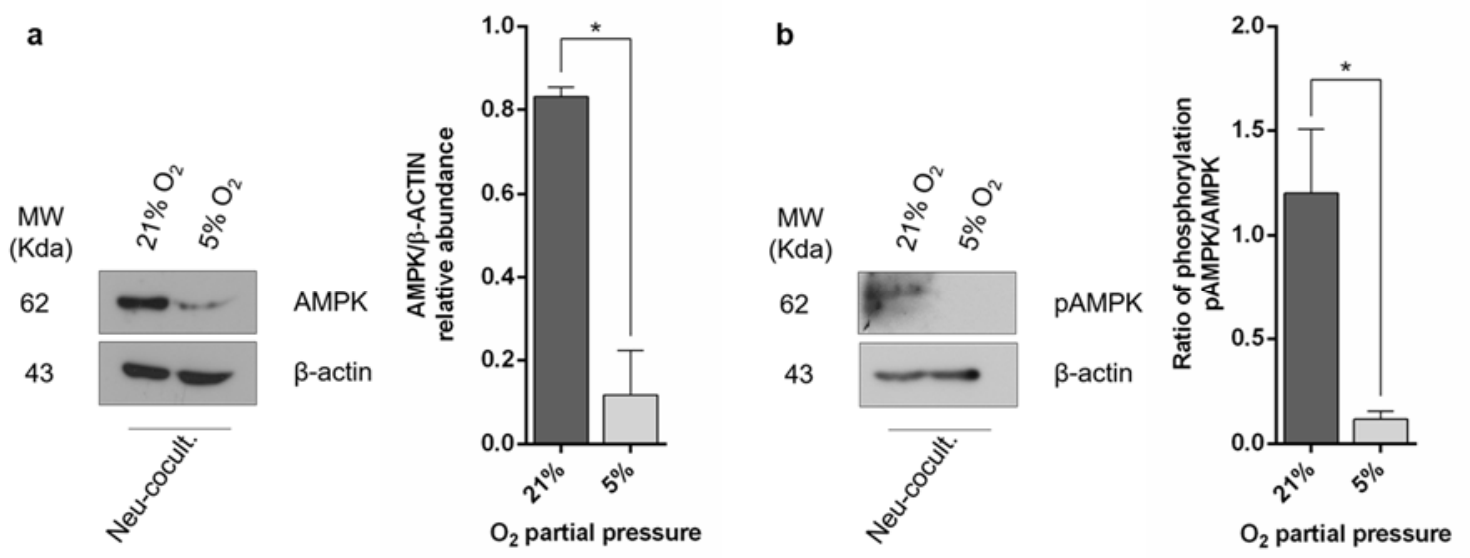

Figure 44. Effect of physiological $\mathrm{pO}_{2}$ on $\mathrm{AMPK}$ protein expression and its phosphorylation rate. Neurons were co-cultured as indicated in 3.2.3. at normoxic (21\%) and physiological (21\%) $\mathrm{pO}_{2}$ pressures. Cellular extracts were prepared as described in 3.5. previous to Western blot analysis. A Student's T-test was performed for statistical analysis $\left({ }^{*} p<0.05\right.$ for at least three different experiments). 
4.4.9. Physiological $\mathrm{pO}_{2}$ induces an increase in $\mathrm{ACC}$ protein expression but a reduced rate of phosphorylation in co-cultured neurons

A substrate of AMPK dependent phosphorylation is the Acyl-CoA Carboxylase (ACC). ACC catalyzes acetyl-CoA carboxylation to produce malonyl-CoA, the fatty acid biosynthesis precursor and the unique regulatory point of the fatty acid biosynthesis pathway. Moreover, ACC phosphorylation negatively regulates ACC protein activity. Thus, the changes observed in the phosphorylation ratio of AMPK could have an effect on the regulation of ACC and, hence, on fatty acid synthesis.

In order to test this possibility, co-cultured neurons were incubated in physiological (5\%) and normoxic $(21 \%) \mathrm{pO}_{2}$, and subjected to a Western blot analysis against Acetyl-CoA Carboxylase (fig. 45a). As therein depicted, at physiological $\mathrm{pO}_{2}$, co-cultured neurons showed a higher ACC protein levels. However, the proportion of ACC protein phosphorylation significantly decreased, by about two thirds (fig. 45b), suggesting an increase of the fatty acid biosynthesis pathway activity.

a

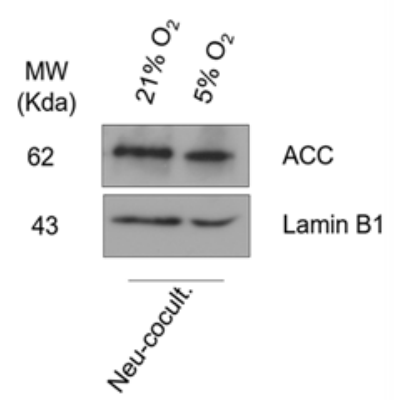

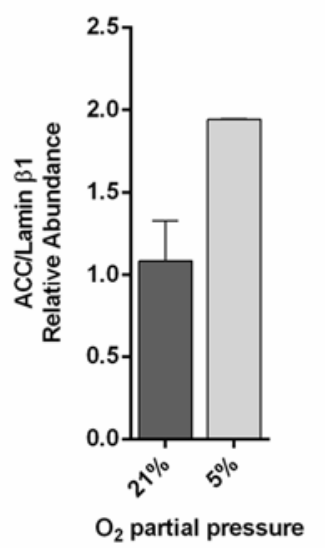

b

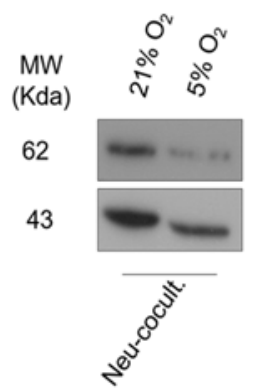

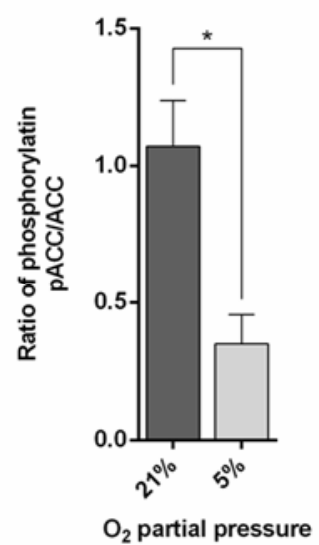

Figure 45. Effect of atmospheric p $\mathrm{O}_{2}$ on ACC protein expression. Neurons were co-cultured as indicated in 3.2.3. at their correspondent $\mathrm{pO}_{2}$. Whole cell extracts were prepared as described in 3.5. previous to Western blot analysis. A Student's T-test was performed for statistical analysis $\left({ }^{*} p<0.05\right.$ for at least three different experiment). 


\subsubsection{Physiological $\mathrm{pO}_{2}(5 \%)$ reduces PPP related genes mRNA transcripts in co-}

cultured neurons and astrocytes, compared to $21 \% \mathrm{pO}_{2}$

Glycolysis and PPP are metabolically interconnected pathways because PPP uses glucose6-phosphate as a substrate, and the non-oxidative phase of PPP yields the glycolytic intermediaries fructose-6-phosphate and glyceraldehyde-3-phosphate. Given the occurring changes in glycolysis in neurons when they were co-cultured at physiological $\mathrm{pO}_{2}(5 \%)$, respect to the canonical $\mathrm{pO}_{2}$ content $(21 \%)$, we decided to test if PPP suffers any change under the same conditions.

The transcriptomic analysis (fig. 46a) indicated that the mRNA abundance of two of the PPP-related genes were significantly reduced when neurons were incubated at 5\% pO2 respect to $21 \% \quad \mathrm{pO}_{2}$ (Transaldolase, -1.55 fold; $\mathrm{p}<0.01$; 6-Phosphogluconate Dehydrogenase, 6PGDH, -2.85 fold; $\mathrm{p}<0.001$ ). Although with a dropping tendency, none of the other PPP enzymes showed statistically significant variations.

Not a very different pattern was observed in the transcriptional expression of astrocytic PPP related genes, under the same conditions. Although the oxidative phase of PPP shows a generalized blue colour in the heatmap, indicating increased expression (fig. 46b), none of the changes was statistically significant. On the contrary, in the non-oxidative phase, both Transaldolase and Ribulose Phosphate Epimerase mRNA transcripts were significantly reduced. 


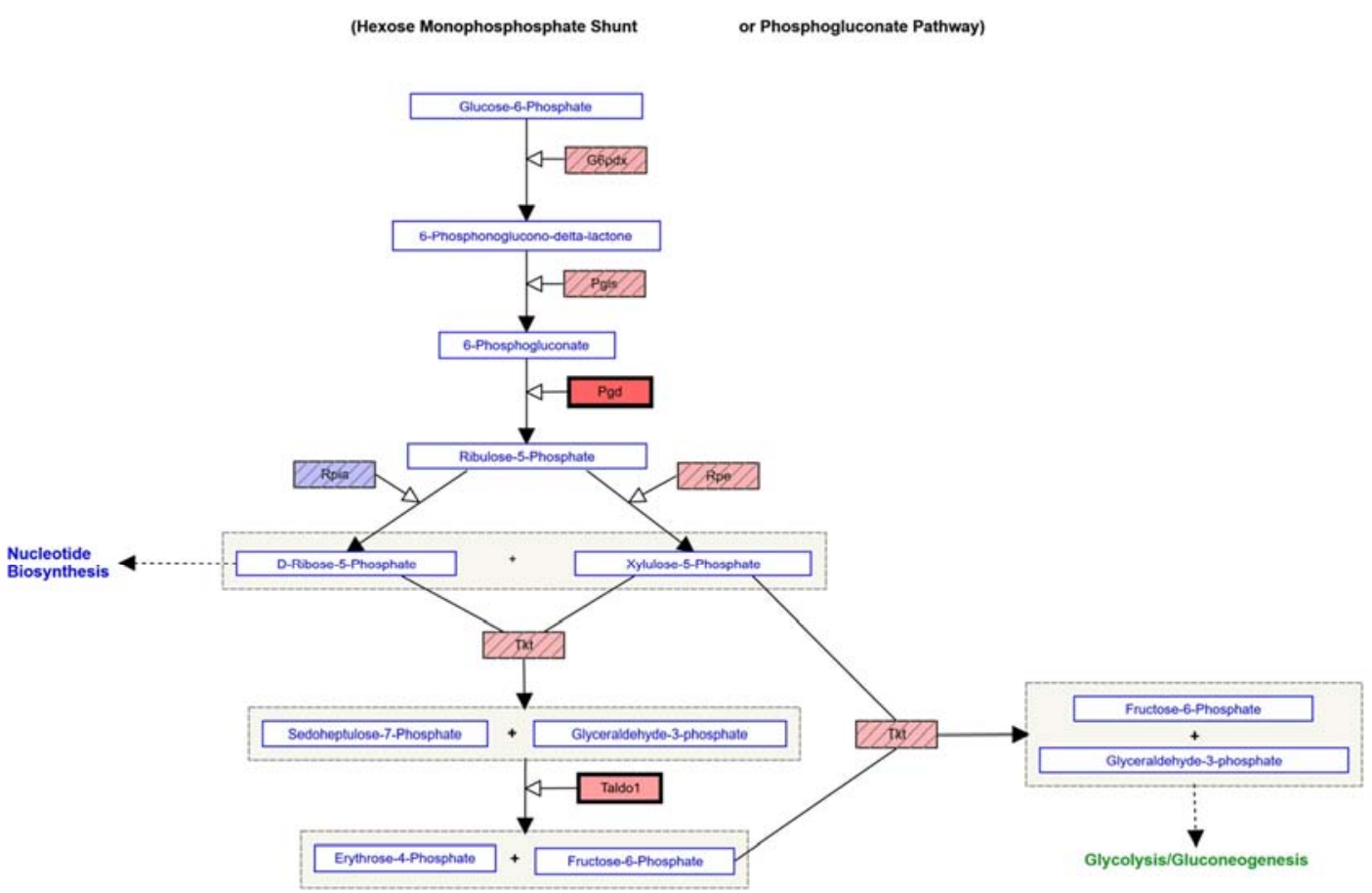

Co-cultured Astrocytes - Pentose Phosphate Pathway

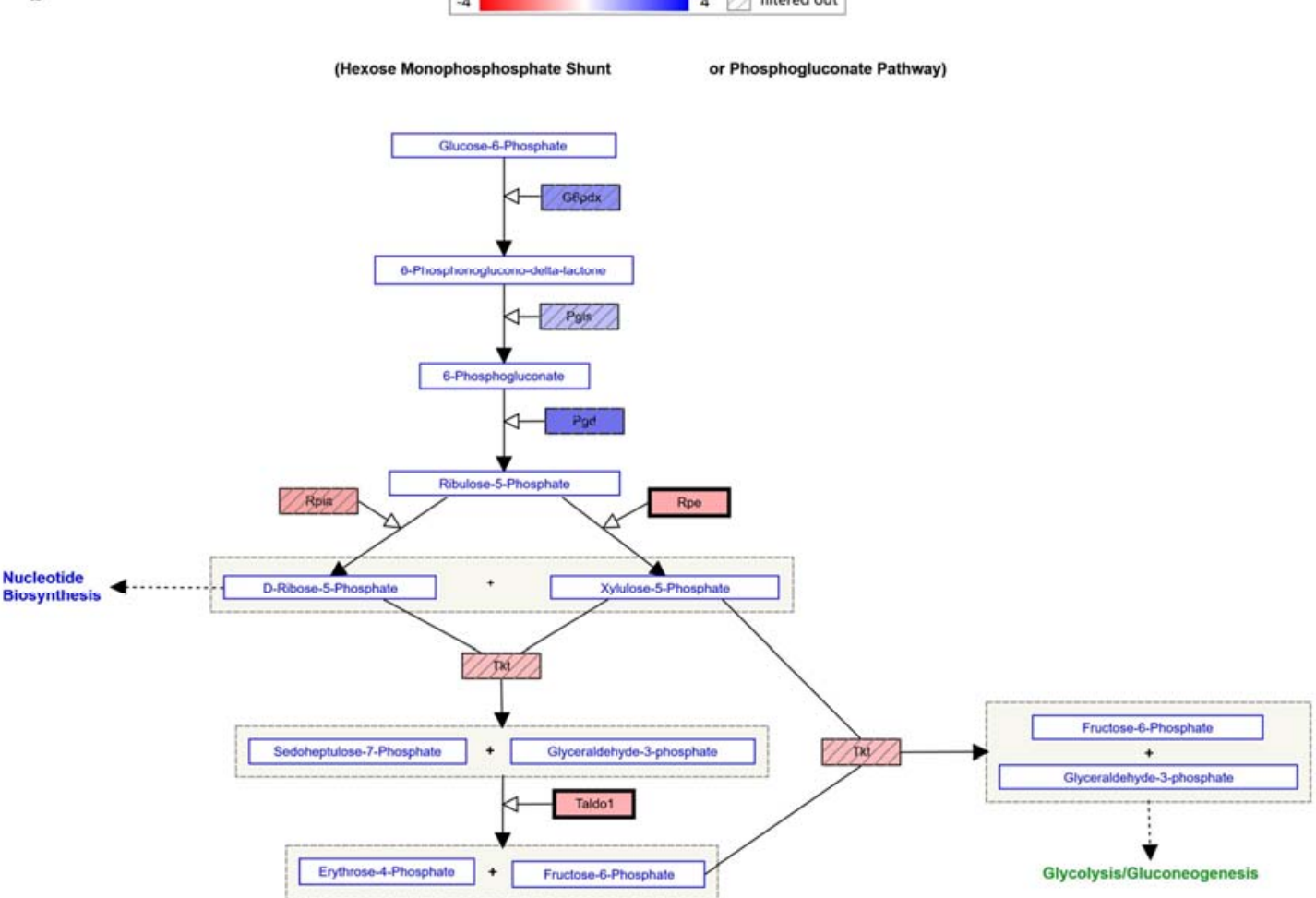

Figure 46. Differential mRNA expressions of PPP related genes in co-cultured neurons (a) and astrocytes (b) at $5 \% \mathrm{pO}_{2}$ vs. $21 \% \mathrm{pO}_{2}$. Samples were analysed in triplicate using Agilent Bioanalyzer for quality and purity check then Clariom ${ }^{\mathrm{TM}} \mathrm{D}$ assays, mouse tools for arrays hibridization and Affymetrix Transcriptomic Analysis Console software provided by the manufacturer. Blue coloured boxes indicate increased expression whereas red coloured boxes indicate reduced expression. Solid boxes with dark borders indicate significant variations of $5 \%$ vs. $21 \%(p<0.05)$. During the analysis, limit values of "Fold Change" for selecting changed expression genes were chosen of $>+1.3$ and $<-1.3$ 
4.4.11. Physiological $\mathrm{pO}_{2}$ reduces $6 \mathrm{PGDH}$ protein expression and activity in co-cultured neurons

Given the reduced abundance of neuronal 6PGDH mRNA observed in the preceding section, we considered to determine the enzymatic activity.

Incubating neuron/astrocyte co-cultures at the physiological $\mathrm{pO}_{2}(5 \%)$ significantly reduced the activity of $6 \mathrm{PGDH}$ in both cell types respect to those cells incubated at the canonical $21 \% \mathrm{pO}_{2}$ (fig. 47 ). The observed reductions were about $40 \%$ for neurons and $80 \%$ for astrocytes. These reductions were corroborated by Western Blot analysis (fig. 48) in the case of co-cultured neurons, with a significant reduction in the amount of 6PGDH protein. Surprisingly, Western blot analysis did not reflect any difference between astrocytes cultured at $5 \% \mathrm{pO}_{2}$ and those at $21 \% \mathrm{pO}_{2}$. Since the transcriptomic analysis did not show any increase in the expression of astrocytic 6PGDH mRNA (fig. 46b), this result deserves further investigation to be clarified.
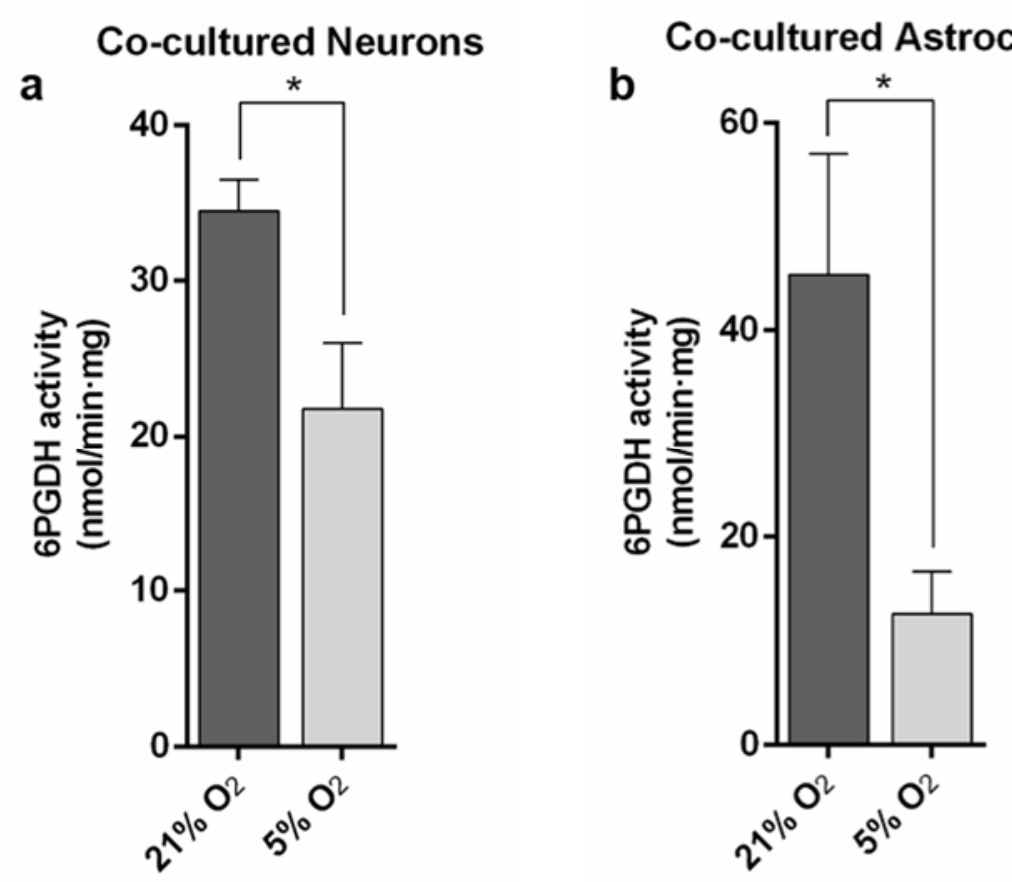

Figure 47. Effect of atmospheric $\mathrm{pO}_{2}$ on 6PGDH activity in co-cultured cells. Cocultures of neurons and astrocytes were incubated during 6 days at $21 \%$ and $5 \%$ $\mathrm{pO}_{2}$, as described in 3.2.3. Samples were collected and activity measured spetrophotometrically as described in 3.10.4. A Student's T-test was performed for statistical differences $\left({ }^{*} p<0.01\right.$, of at least three different experiments). 

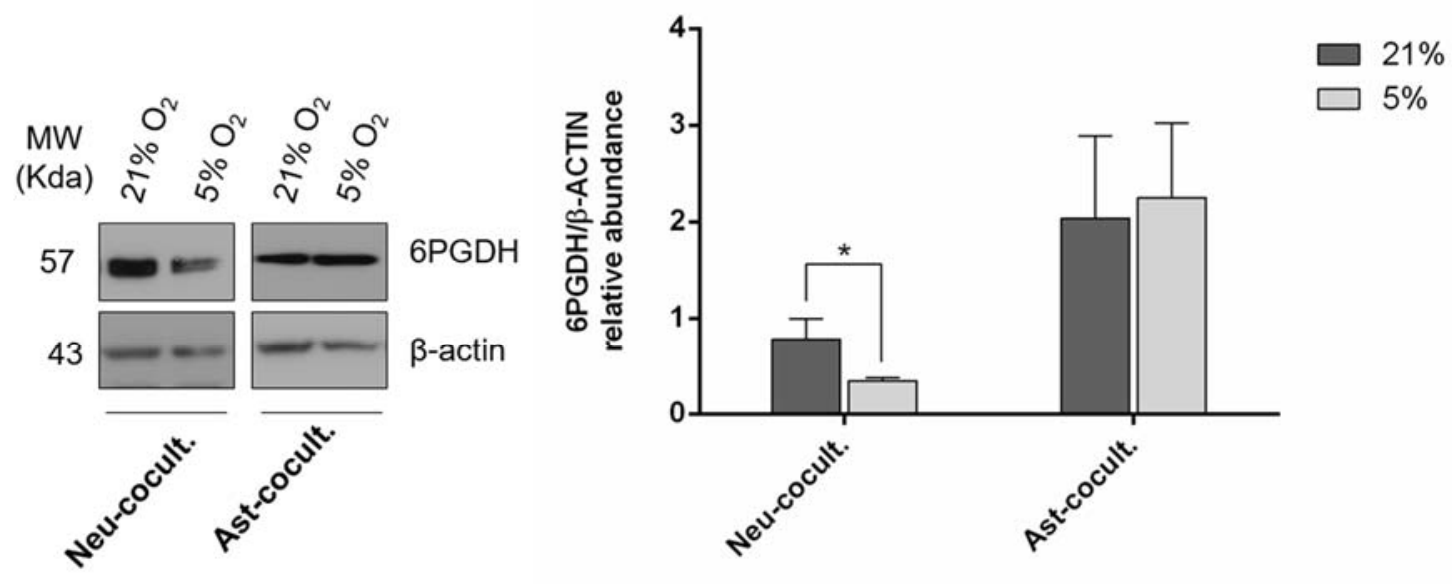

Figure 48. Effect of atmospheric p $\mathrm{O}_{2}$ on $6 \mathrm{PGDH}$ protein expression in co-cultured neurons and astrocytes. Co-cultures were incubated during 6 days at $21 \%$ and $5 \% \mathrm{pO}_{2}$, as described in 3.2.3. Cellular extracts were prepared as described in 3.5. previous to Western blot analysis. A Student's T-test was performed for statistical differences $\left({ }^{*} p<0.01\right.$, of at least three different experiments).

4.4.12. Physiological $\mathrm{pO}_{2}$ increases mitochondrial $\mathrm{O}_{2}^{-}$- but reduces $\mathrm{H}_{2} \mathrm{O}_{2}$ in co-cultured neurons

In the previous results (fig. 26) we showed that, at physiological $\mathrm{pO}_{2}\left(5 \% \mathrm{O}_{2}\right)$, neurons have an increased production of mROS. In order to further investigate the possible relationship between mROS production and the observed changes in glucose metabolism in co-cultured cells, we first tried to confirm the neuronal mROS production by two methods. We used the MitoSox ${ }^{\circledR}$ assay by flow cytometry for testing the mitochondrial $\mathrm{O}_{2}$ - production, and the AmplexRed ${ }^{\circledR}$ assay with Varioskan Flash fluorimeter readings for determination of the $\mathrm{H}_{2} \mathrm{O}_{2}$ production, as described in the section 3.8.2.

As shown in fig. 49, $\mathrm{O}_{2}{ }^{-2}$ reflected by MitoSox ${ }^{\circledR}$ fluorescence, was significantly increased at physiological (5\%) $\mathrm{O}_{2}$ compared to $21 \% \mathrm{pO}_{2}$ in co-cultured neurons. Surprisingly, $\mathrm{H}_{2} \mathrm{O}_{2}$ measured by the AmplexRed ${ }^{\circledR}$ assay was significantly reduced. 


\section{Co-cultured Neurons}

a

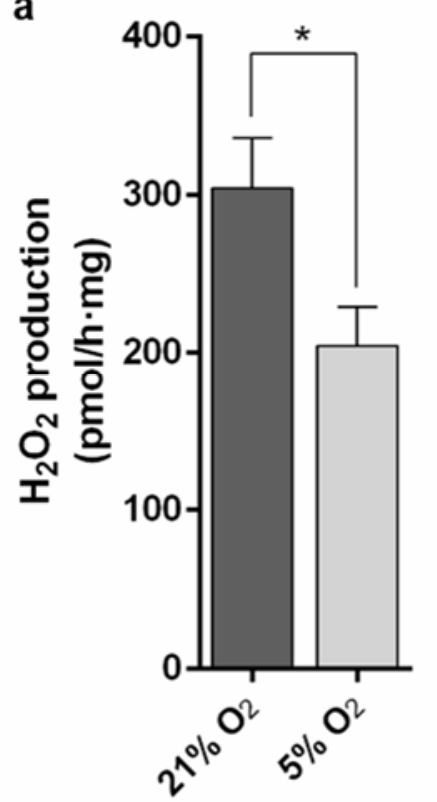

\section{Co-cultured Neurons}

b

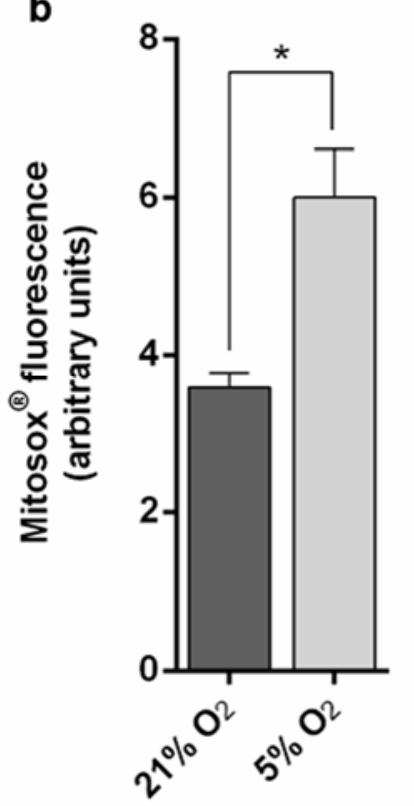

Figure 49. Effect of atmospheric $\mathrm{pO}_{2}$ on the production of $\mathrm{mROS}$ (a) and cellular $\mathrm{H}_{2} \mathrm{O}_{2}$ (b) in co-cultured neurons. mROS were tested by using the MitoSox ${ }^{\circledR}$ assay in the intact cells by flow cytometry as described in section 3.8.1., or using the AmplexRed ${ }^{\circledR}$ assay in living cells with a Varioskan Flash fluorimeter measurement as described in 3.8.2. Neurons were incubated in co-culture with astrocytes at the correspondent $\mathrm{pO}_{2}$, as described in 3.2.3., and at day 6 they were analysed. A Student's T-test was performed for statistical differences $\left({ }^{*} p<0.01\right.$, of at least three different experiments).

4.4.13. Reduced expression of the mitochondrial manganese-dependent Superoxide Dismutase (MnSOD; SOD2) at physiological $\mathrm{pO}_{2}$ in co-cultured neurons

Superoxide dismutase 2 or Manganese-dependent superoxide dismutase (SOD2, MnSOD) is part of the mitochondrial antioxidant system. It transforms the free radical superoxide $\left(\mathrm{O}_{2}{ }^{-}\right)$into $\mathrm{H}_{2} \mathrm{O}_{2}$ and, in this way, collaborates in detoxifying ROS in mitochondria, (see 1.4.2). Given the involvement of SOD2 in the relationship between the $\mathrm{O}_{2}-$ and $\mathrm{H}_{2} \mathrm{O}_{2}$, we sought to determine the expression levels of SOD2. As can be seen in fig. 50, Western blot analysis of total protein from co-cultured neurons shows a significant $80 \%$ reduction of SOD2 protein expression at physiological $\mathrm{pO}_{2}(5 \%)$ compared to the normoxic $21 \% \mathrm{pO}_{2}$. This reduction could be interpreted as a reduction in $\mathrm{O}_{2}-$ dismutation and, hence, a reduced $\mathrm{H}_{2} \mathrm{O}_{2}$ level. 


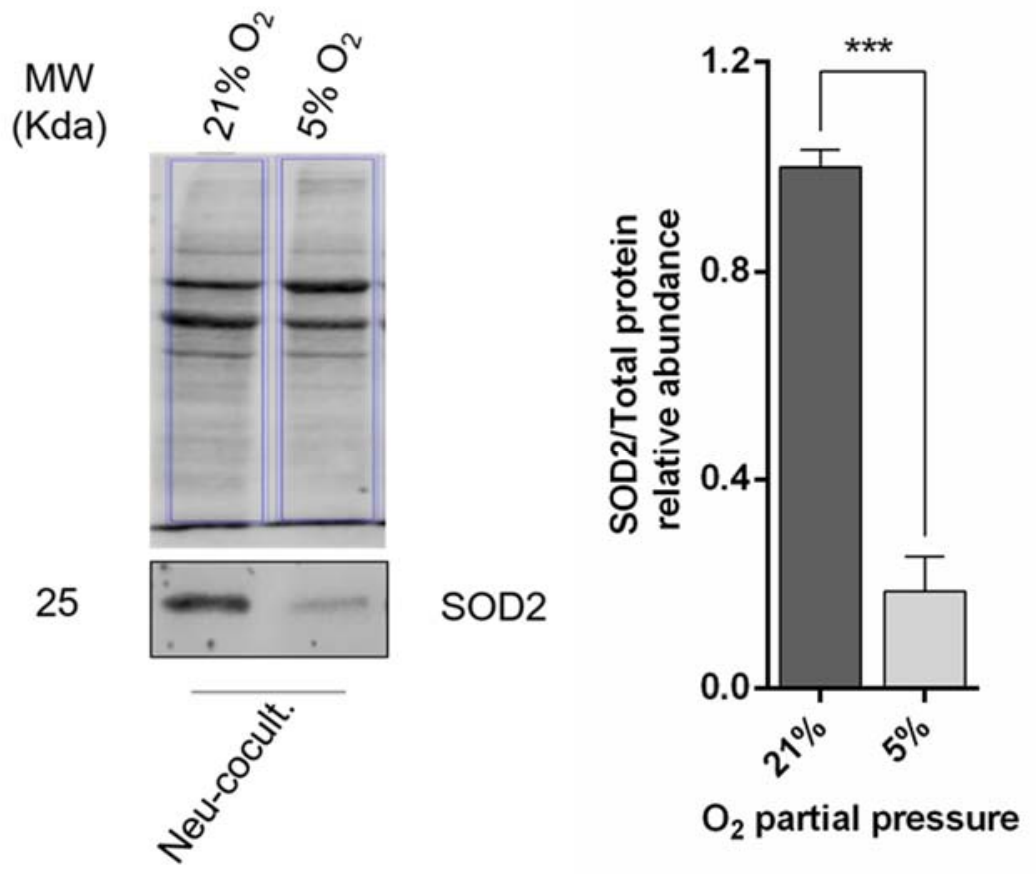

Figure 50. Effect of atmospheric $\mathrm{pO}_{2}$ on $\mathrm{SOD} 2$ protein expression. Neurons were co-cultured as indicated in 3.2.3. at their correspondent $\mathrm{pO}_{2}$. Cellular extracts were prepared as described in 3.5. previous to Western blot analysis. A Student's T-test test was performed for statistical analysis. $\left({ }^{*} p<0.01\right.$, of at least three different experiments).

4.4.14 Physiological $\mathrm{pO}_{2}$, in co-cultured neurons, induces changes in the levels of mRNA transcripts involved in energy metabolism

From the transcriptomic analysis, we identified a set of genes some of which have been the focus of studies shown in the previous sections. For the selected genes, we performed a RT-qPCR analysis that allowed us to confirm their relative mRNA levels. For these analyses, we used the $\beta$-actin mRNA abundance as a reference. According to fig. 51, we conclude that, respect to the canonical $21 \% \mathrm{pO}_{2}$, incubating neuronal co-cultures at the lower physiological $\mathrm{pO}_{2}(5 \%)$ triggered:

- A 10-fold highly significant increase of HKII in mRNA abundance, which is consistent with the results shown in section 4.4.6, and with what was observed in the transcriptomic analysis.

- A non-significant alteration of SOD2 mRNA abundance, in juxtaposition to what we observed in the previous section, suggesting an increased destabilization of the protein. 
- A significant 6-fold increase in NDUFA4L2 (NADH dehydrogenase [ubiquinone] 1 alpha subcomplex, 4-like 2) mRNA abundance. NDUFA4L2 is a subunit of the mitochondrial Nicotinamide Dinucleotide Transhydrogenase linked to $\mathrm{O}_{2}$ consumption.

- A significant 10-fold reduction of 6PGDH mRNA abundance, which is consistent with the results shown in section 4.4.11, and the transcriptomic results (Fig 45a).

- A significant 4-fold increase of PDK1 (Pyruvate Dehydrogenase Kinase 1) mRNA abundance. PDK1 is a mitochondrial matrix enzyme responsible of the phosphorylation-dependent inhibition of Pyruvate Dehydrogenase. This enzyme regulates energy metabolism by controlling the acetyl-CoA supply to the Tricarboxylic Acid cycle (TCA).

- A significant 2-fold decrease of CPT1A (Carnitine palmitoyltransferase 1A). mRNA abundance. CPT1A is a mitochondrial membrane protein responsible for the transport across the membrane of the acyl-carnitine, for the $\beta$-oxidation of fatty acids, and is a HIF-1 and HIF-2 target gene.

\section{RT-qPCR}

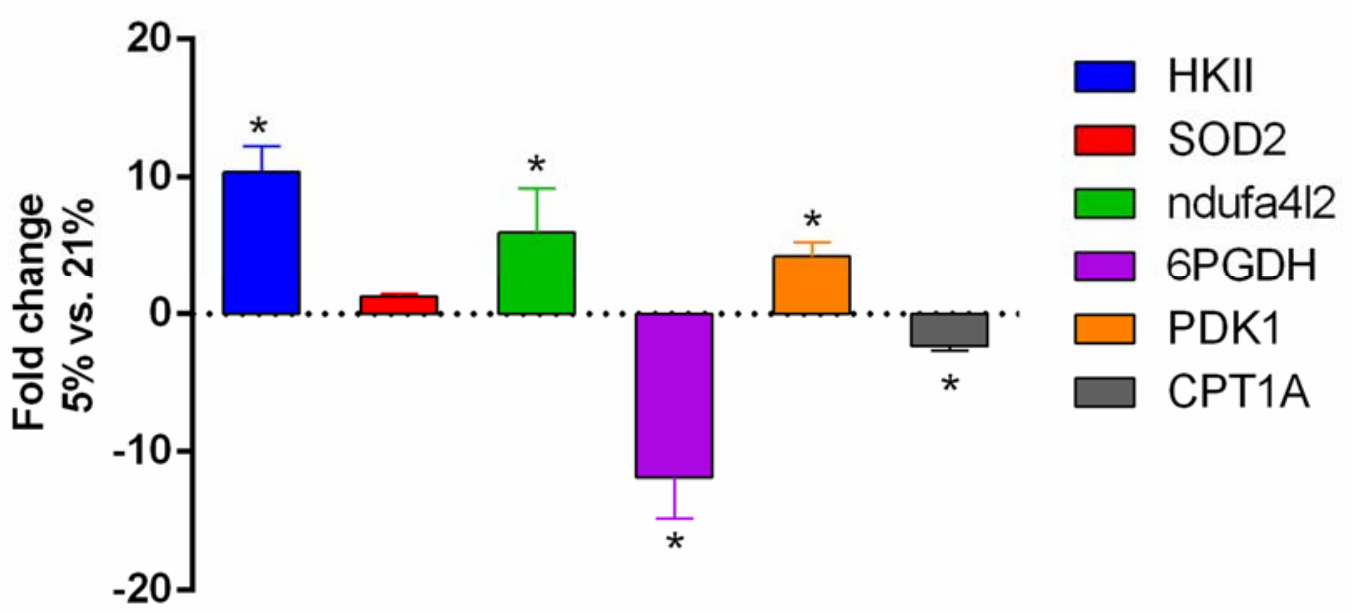

Figure 51. Effect of physiologicl p $\mathrm{O}_{2}$ on $\mathrm{RNA}$ expression of energy metabolism related genes. Neurons were co-cultured as indicated in 3.2.3. at 21\% and $5 \% \mathrm{pO}_{2}$. RT-qPCR was performed in purified RNA samples, extracted using RNeasy ${ }^{\circledR}$ Mini Kit as described in section 3.13. mRNA abundance of each transcript was normalized to $\beta$-actin mRNA abundance. A Student's T-test test was performed for statistical analysis comparing $5 \%$ to $21 \% \mathrm{pO}_{2}$ for each gene. $\left({ }^{*} p<0.05\right.$, of at least three different experiments). 


\subsubsection{Changes in cell cycle parameters of co-cultured neurons after incubation at}

physiological $\mathrm{pO}_{2}(5 \%)$, respect to the canonical $\mathrm{pO}_{2}(21 \%)$

The cell cycle parameters of co-cultured neurons were analysed by flow cytometry measuring bromodeoxyuridine (BrdU) incorporation into DNA. As observed in fig. 52, neurons incubated at physiological $\mathrm{pO}_{2}$ showed a significant decrease in the S-phase, and an increased $\mathrm{G} 0 / \mathrm{G} 1$-phase, while $\mathrm{G} 2+\mathrm{M}$ phase was not significantly changed compared to normoxical $\mathrm{pO}_{2}$. These results were consistent with the transcriptomic analysis (fig. 53), in which the generalized red tone of gene abundances in the heatmap indicates that mRNA transcription of almost all proteins associated to cell cycle was significantly down-regulated. This suggests a higher degree of maturation of neurons co-cultured at the physiological $5 \%$ $\mathrm{pO}_{2}$, respect to those co-cultured at the canonical $21 \% \mathrm{pO}_{2}$.
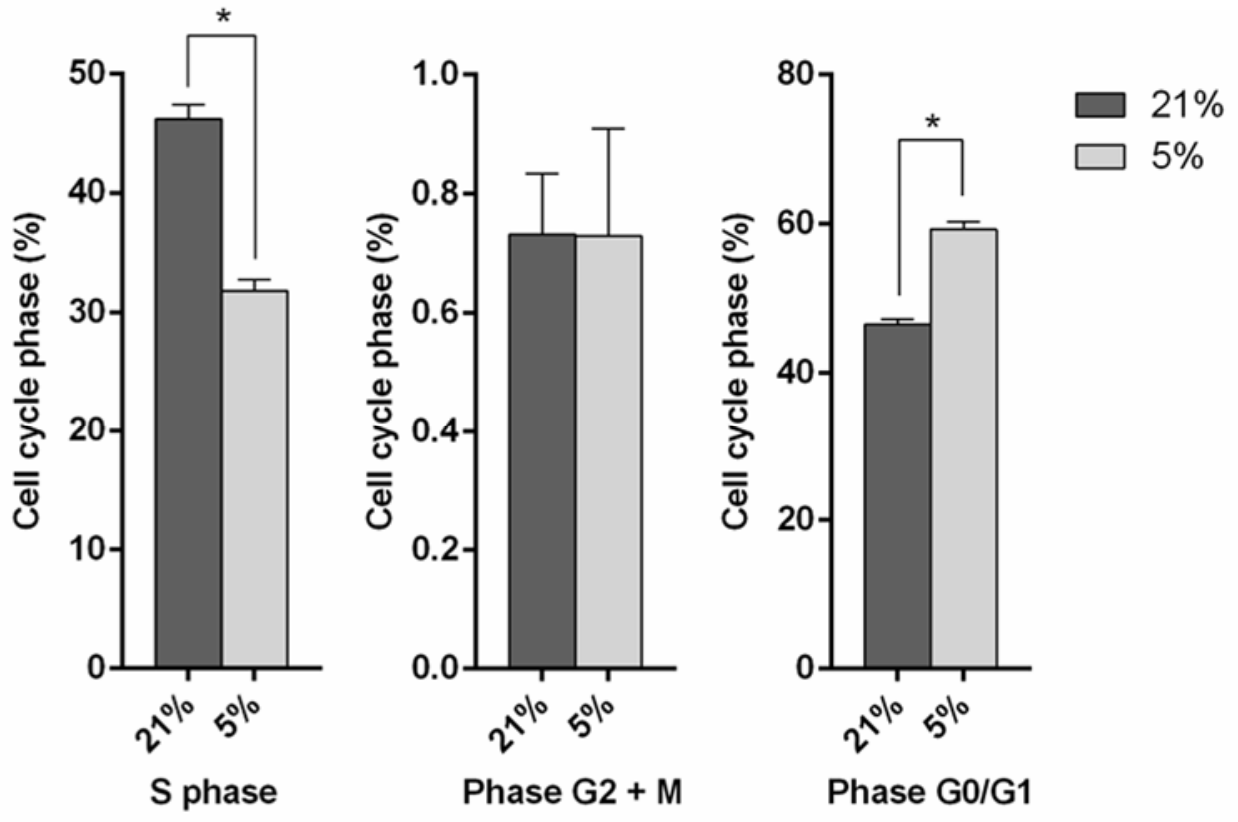

Figure 52. Effect of physiological $\mathrm{pO}_{2}$ (5\%) on cell cycle phases in co-cultured neurons. Neurons were co-cultured as indicated in 3.2.3. Cell cycle phases were quantified by flow cytometry based on BrdU incorporation into DNA as described in section 3.12. A Student's Ttest test was performed for statistical analysis $\left({ }^{*} p<0.01\right.$, from at least three different experiments). 


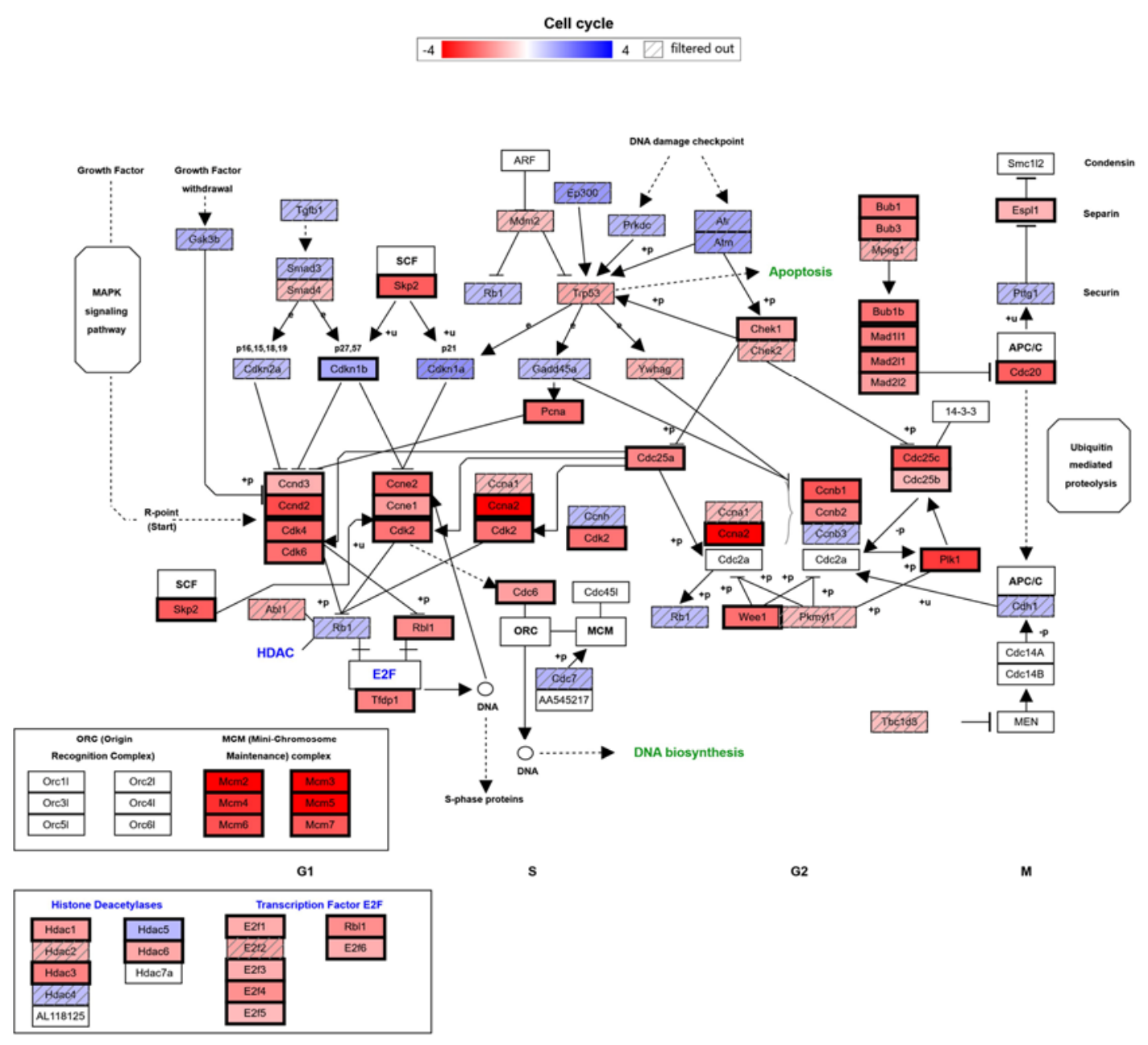

Figure 53. Differential mRNA expressions of Cell Cycle related genes in co-cultured neurons at 5\% $\mathrm{pO}_{2}$ vs. 21\% $\mathrm{pO}_{2}$. Samples were analysed in triplicate using the Agilent Bioanalyzer for setting their quality and purity, the Clariom ${ }^{\mathrm{TM}} \mathrm{D}$ assays mouse tools for arrays hybridization and the Affymetrix Transcriptomic Analysis Console software provided by the manufacturer. Blue coloured boxes indicate increased expression whereas red coloured boxes indicate reduced expression. Solid boxes with dark borders indicate significant variations of $5 \% \mathrm{vs.} 21 \%(p<0.05)$. During the analysis, limit values of "Fold Change" for selecting changed expression genes were chosen of $>+1.3$ and $<-1.3$. 


\section{5- Discussion}

\subsection{Physiological $\mathrm{pO}_{2}$ improves survival and has differential effects on $\Delta \psi_{m}$ and $m R O S$}

production in neurons and astrocytes

Traditionally, primary cultures of nerve cells have been performed under standard environmental conditions, typical of most cell cultures, that are: temperature of $37^{\circ} \mathrm{C}$ and an atmosphere with $21 \% \mathrm{pO}_{2}$ and $5 \% \mathrm{pCO}_{2}$. However, although the standard temperature and $\mathrm{pCO}_{2}$ are close to the physiological situation in the tissue "in vivo", the atmospheric $\mathrm{pO}_{2}$ used in the cultures is far from the physiological levels, which oscillate between $1 \%$ and $10 \%$ depending on the distance from the blood capillaries to the cells (see section 1.1.1). Thus, it is not unreasonable to suspect the existence of optimal $\mathrm{pO}_{2}$ levels for culturing neurons and astrocytes resembling their natural $\mathrm{pO}_{2}$ in the organism. In our study, in order to clarify the optimal $\mathrm{pO}_{2}$ level, we performed primary cortical cultures and co-cultures of mice neurons and astrocytes at different $\mathrm{pO}_{2}$ ranging from $1 \%$ to $6 \%$, and at $21 \%$, using as selection criteria apoptotic cell death, $\Delta \psi_{\mathrm{m}}$ and $\mathrm{mROS}$.

It has been described that mROS and $\Delta \psi_{\mathrm{m}}$ inversely correlate in hypoxia, and that high mROS production is tightly associated with apoptosis (Abramov et al., 2007; Angelova \& Abramov, 2018; Sullivan \& Chandel, 2014). However, apoptosis of astrocytes and neurons, measured by flow cytometry with annexin- $\mathrm{V}$ and 7AAD, significantly decreased in both cell types after being cultured during 6 days at $5 \%$ and $6 \% \mathrm{pO}_{2}$, compared to the cultures at $21 \% \mathrm{pO}_{2}$ (fig. 24). Under the same conditions, the production of mROS was increased in neurons but it did not experience major changes in astrocytes (fig. 26); however, the $\Delta \psi_{\mathrm{m}}$ increased significantly in astrocytes but was reduced in the neurons (fig. 25). Also, at the physiological $5 \% \mathrm{pO}_{2}$, the transcriptomic analysis (fig. 32) indicates that transcription levels of ETC related genes was overally reduced in both cell types. Taken together, these results indicate that, in neurons, the decrease in apoptotic death observed at physiological oxygen concentrations is associated with the reduction in $\Delta \psi_{\mathrm{m}}$ and with the increase in mROS production. It is noteworthy that the mRNA of UCP1 is the only transcript that was significantly increased amongst the rest of the ETC-related genes in neurons (fig. 32a). This result could explain the reduction in $\Delta \psi_{\mathrm{m}}$ in neurons cultured at $5 \% \mathrm{pO}_{2}$. It should be mentioned that $5 \% \mathrm{pO}_{2}$ is within the range of $\mathrm{pO}_{2}$ expected in the cortex of the mice brain (Xu et al., 2017) and, hence, it cannot be considered as a hypoxic but physiologic situation. Thus, under our experimental conditions, the increase in mROS production seems to have 
positive effects on neuronal survival. The relationship between mROS production and neuronal survival during adaptation to $5 \% \mathrm{pO}_{2}$ remains to be clarified.

In astrocytes, since there are no substantial changes in mROS production, the reduction in apoptotic death could be mainly associated to highly polarized mitochondria (fig. 25). Because there is no change in the expression of uncoupling proteins, as seen in the transcriptomic results (fig. 32b), the increase in $\Delta \psi_{\mathrm{m}}$ could be the result of the mitochondrial re-structuration (figs. 27 to 30). This aspect will be discussed in the following section.

In co-cultures, although the mere presence of astrocytes improved neuronal survival at normoxic and physiological $\mathrm{pO}_{2}$, incubation at $5 \% \mathrm{O}_{2}$ additionally reduced neuronal apoptosis by about $50 \%$ (fig. 33a: striped bars), without significantly affecting neither $\Delta \psi_{\mathrm{m}}$ nor mROS production (figs. 34a and 35a). Conversely, astrocytes were unaffected in the three above-mentioned parameters. Neuronal and astrocytic transcriptomic analysis of both ETC and OxPhos related mRNA transcripts, under these conditions (fig. 36), reveals an overall reduction in the transcription of ETC and OxPhos and shows no substantial differences with those of neurons and astrocytes cultured alone. Thus, these results suggest that by being incubated under $5 \% \mathrm{pO}_{2}$, neurons increase their survival rate independently of the presence of astrocytes, and that such an improvement correlates with the down-regulation of ETC and OxPhos related gene expression.

Although the presence of astrocytes substantially increased neuronal survival, amongst others effects, in order to analyze in depth the possible changes in the metabolism of neurons and astrocytes by the presence of the other cell type in co-culture was outside the scope of this work.

\subsection{Physiological $\mathrm{pO}_{2}$ modulates mitochondrial shapes and ETC Complexes structural organization}

The study of mitochondrial morphology under the different oxygen concentrations showed three types of shape, with large interconnected networks as a dominant form in astrocytes at the physiological 5\% $\mathrm{pO}_{2}$; however, in neurons the dominant form is fragmented mitochondria. Astrocytic mitochondria analysed by electron microscopy show an increase in the network, interconnected organelles (fig. 28a) together with a significant reduction in cristae maximal width at $5 \% \mathrm{pO}_{2}$ compared to $21 \% \mathrm{pO}_{2}$ (fig. 28b). This is in line with a better conservation of OPA1 (fig. 30), which is key at maintaining respiratory chain 
super-complex assembly (Cogliati et al., 2013). At physiological $\mathrm{O}_{2}$ found in the brain $(5 \%$ $\mathrm{pO}_{2}$ ), mitochondria showed to be more elongated, which would provide a better cristae surface likely to harbour more super-complexes and improved respiration when $\mathrm{O}_{2}$ is low, thus avoiding apoptosis (Cogliati et al., 2013; Varanita et al., 2015). However, the transcriptomic analysis (figs. 32 and 36) indicates a reduction in the expression of ETC and OxPhos complexes components, suggesting a restructuration of the respiratory complexes better than an increase in their amounts. In fact, the number of cristae in mitochondria is increased when astrocytes are cultured at low, physiological $\mathrm{pO}_{2}$ (5\%) (fig. 28c) confirming a tendency towards an ultrastructure conformation supporting high respiratory status requirements (Gomes et al., 2011).

When studying OPA1 levels (fig. 30), we observed an increase in the c, d and e isoforms with a reduction of the isoforms $a$ and $b$ in neurons. This could be due to a higher expression of the metalloendopeptidase OMA1 that induces the cleavage of the long isoforms of OPA1, $a$ and $b$, to give rise to the short ones (c, $d$ and e). Conversely, astrocytes cultured at 5\% $\mathrm{O}_{2}$ maintain the OPA1 isoforms profile with an increase in the detected amounts of OPA1 long isoforms. This might mean a physiological support of astrocytes for respiratory metabolism and redox signalling to neurons. Kim and collaborators showed that mitochondria in mouse fibroblast cells, maintained for 24 hours under hypoxia, were less elongated and more fragmented depending on availability of AKAP121 (a mitochondrial scaffolding protein), suggesting hypoxia-induced mitochondrial remodelling (H. Kim et al., 2011). However, our results with astrocytes show that reduction of $\mathrm{O}_{2}$ availability from $21 \%$ to $5 \%$ promotes mitochondrial changes in the opposite direction, i.e. towards a more elongated and interconnected form (fig. 29a), probably because 5\% $\mathrm{pO}_{2}$ cannot be considered a hypoxic, but a physiological situation. In fact, both astrocytes and neurons improved their survival at $5 \% \mathrm{pO}_{2}$, suggesting a more efficient utilization of the energy resources, which is supported by the observed restructuration of neuronal mitochondrial complexes and super-complexes (fig. 31).

Accordingly, ETC complexes organization was modified in co-cultured neurons under physiological $\mathrm{pO}_{2}(5 \%)$, by an increase in free complex I, a decrease in F1 band of complex $\mathrm{V}$ and a modification of complex IV molecular weight (fig. 31). The increased amount in free complex I could explain the higher mROS observed increase in neurons under these conditions. Alteration of complex V and complex IV, as well as the overall reduction in the expression of mRNA of ETC and OxPhos related genes (fig. 36) could signify a switch 
from oxidative phosphorylation to a more anaerobic metabolism. In a related context, Horvat et al. (2006) described a switch in the expression levels of the subunits IV-1 and IV-2 of cytochrome c oxidase (COX IV-1 and COX IV-2) in cerebellar neurons, with an increase in $\mathrm{COX}$ IV-2 under conditions of $\mathrm{O}_{2}$ deprivation. $\mathrm{COX} \mathrm{IV-1}$ is a regulatory subunit responsible for ATP dependent allosteric inhibition of ATP synthesis, whereas COX IV-2 lacks ATP sensitivity, hence the change implies the abolition of the allosteric inhibition of COX by ATP. In our hands, COX IV-2 was not detected according to the transcriptomic analysis of ETC related proteins, but the significant decrease in the astrocytic expression of COX IV-1 (fig. 36b) could point out in this direction in astrocytes. On the contrary, no significant changes in COX IV-1 were observed in neurons. The overall reduction in ETC and OxPhos proteins mRNA expressions, together with the changes in the structures of complexes and super-complexes, suggest a shift towards a more anaerobic metabolism that will be discussed in the next section. The relationships between the changes in ETC and OxPhos mRNA expression and the changes in super-complexes structures deserve further investigation.

\subsection{Increased glucose metabolism in cultured neurons and astrocytes under physiological $\mathrm{pO}_{2}$}

Neurons and astrocytes cultured separately at $5 \% \mathrm{pO}_{2}$ show significant increases in glucose consumption and lactate accumulation when compared at $21 \% \mathrm{pO}_{2}$ (fig. 37). This increase was concordant with the increased expression of glycolysis-related mRNA transcripts as revealed by the transcriptomic analysis (fig. 38). These results clearly support a shift towards an anaerobic metabolism in both cell types, as it has been pointed out in the previous section. It is noteworthy that expression of glucose transporter GLUT1 mRNA (gene Slc2a1) in neurons increase about 27 times upon incubation at 5\% $\mathrm{pO}_{2}$. This increase in GLUT1 expression level may be an environmental adaptation to glucose in medium (Maher et al., 1996). However, the samples were obtained from cultures at 21\% and 5\% $\mathrm{pO}_{2} 24 \mathrm{~h}$ after changing media, thus it is unlikely that differences in glucose are responsible for such an increase in GLUT1 expression. It should be also mentioned that the transcriptomic analysis show a 4.2 fold increase of glycolysis activator protein PFKFB3 mRNA in neurons, after $5 \% \mathrm{pO}_{2}$ incubation, indicating a plausible strong activation of glycolytic pathway. Herrero-Mendez et al. in 2009 described that although PFKFB3 mRNA was present in neurons cultured at $21 \% \mathrm{pO}_{2}$, the protein content was negligible because of its continuous APC/C-Cdh1 mediated proteasomal degradation. Our results 
show that neuronal and astrocytic glycolytic activity was increased about twice by culturing cells at the physiological 5\% $\mathrm{pO}_{2}$ (fig. 39), suggesting the occurrence of another form of regulating PFKFB3 at the transcriptional level.

According to the data obtained in mono-cultures, incubations of neuron/astrocyte cocultures at the physiological $5 \% \mathrm{pO}_{2}$ significantly increased the expression of almost all glycolytic genes in neurons, but not in astrocytes, as seen in the transcriptomic scheme (fig. 40). These transcriptomic results were partially confirmed by Western Blot analysis of Hexokinase II (HKII) protein expression, which was significantly increased (fig. 42). The HKII is responsible of the first step of the glycolytic cascade and one of the three limiting steps of the pathway, so it can be used as a good example of pathway activity. Transcriptomic analysis also showed that expression of PFKFB3 mRNA was increased only in neurons, not in astrocytes (data not shown). All these data were confirmed by determination of the glycolytic rates as depicted in fig. 41, where we observed significant increase in co-cultured neurons but not in co-cultured astrocytes.

Since co-cultured astrocytes did not show any change of glycolytic activity, we decided to focus our attention in the metabolic response of co-cultured neurons to the physiological $5 \% \mathrm{pO}_{2}$. Thus, we next tried to study in depth the mechanism responsible for the glycolytic induction.

Given the relationship between the HIFs and $\mathrm{O}_{2}$ availability (see section 1.1.5.1), we decided to investigate the implication of HIF-1 $\alpha$ on neuronal metabolic adaptation to $5 \%$ $\mathrm{pO}_{2}$ compared to the standard $21 \% \mathrm{pO}_{2}$. In contrast to what was expected, Western blot analysis showed that, under $5 \% \mathrm{pO}_{2}$, nuclear content of HIF-1 $\alpha$ was significantly reduced (fig. 43a). This result was confirmed by HRE-luciferase activity assay (fig. 43b) that shows a very significant decrease in fluorescence reflecting low HIF-1 $\alpha$ activity in nuclei of co-cultured neurons. Taken together, these results clearly suggest that when neurons are exposed to $5 \% \mathrm{pO}_{2}$ chronically, HIF-1 $\alpha$ does not seem to be the regulator of glycolysis.

Recently, reviewing non-canonical mechanisms regulating HIF-1 $\alpha$ in cancer, Iommarini et al. (2017), observed a destabilization of HIF-1 $\alpha$ under low $\mathrm{pO}_{2}$ due to inhibitions of ETC activity, with the consequent increase in intracellular $\mathrm{pO}_{2}$. Thus, caused pseudonormoxia and activation of the Prolyl-hydroxylase control system. Provided this was the case under our conditions, the observed reduction in the expression levels of ETC and OxPhos related protein mRNAs (fig. 40) could be responsible for the down-regulation of HIF-1 $\alpha$. 
We also analysed, by RT-qPCR, the cellular content of CPT1a, a HIF-1 target gene, which was found to be significantly decreased under these conditions (fig. 51). Since CPT1 expression is directly repressed by HIF $1 \alpha$, the observed reduction in the content of CPT1a mRNA could be mediated by other transcription factors, different from HIF-1 $\alpha$. Moreover, this hypothesis remains to be fully elucidated.

Since HIF-1 $\alpha$ and the AMP dependent protein kinase (AMPK) are interconnected pathways (Lee et al. 2010; see section 1.1.5.6), and AMPK is one of the main regulators of energy metabolism, we aimed to investigate whether AMPK could be involved in the metabolic behaviour of neurons co-cultured at $5 \% \mathrm{pO}_{2}$. The analysis of AMPK and pAMPK showed a decrease in the phosphorylation rate (fig. 44 ) of this enzyme at $5 \% \mathrm{pO}_{2}$. Next, we corroborated the observed effects on AMPK by analysing by Western blotting the cellular amounts of ACC1 and phospho-ACC1 (fig. 45). ACC1 is the rate-limiting enzyme of fatty acid synthesis and it is phosphorylated (and deactivated) by AMPK. The significant decrease observed in the rate of ACC phosphorylation (pACC1/ACC1) under physiological $\mathrm{pO}_{2}$ indicates a reduction of the activity of AMPK and suggests a stimulation of fatty acid biosynthesis. These results indicate a reduced activity of AMPK and suggests that energy requirements of co-cultured neurons were fulfilled under physiological $\mathrm{pO}_{2}$. Moreover, Emerling and co-workers (2009) described that AMPK activation in hypoxic conditions $\left(1.5 \% \mathrm{pO}_{2}\right)$ depends on the mROS production rather than on an increase in AMP levels.

\subsection{PPP reduction and differential $m R \mathrm{OS}$ and $\mathrm{H}_{2} \mathrm{O}_{2}$ production under physiological pO2}

Glycolysis analysis showed a significant increase in co-cultured neurons but not in astrocytes. Given the close connection between glycolysis and PPP led us to check for any changes occurring under the same physiological $\mathrm{pO}_{2}$ conditions. The transcriptomic study revealed a significant reduction in Transaldolase and 6-Phosphogluconate Dehydrogenase expression. We investigated 6PGDH protein expression and activity in neurons and astrocytes co-cultured under the physiological $\mathrm{pO}_{2}$, and we detected a significant decrease in protein activity in both cells, but only a significant decrease in protein expression in the co-cultured neurons. The significant reduction of $6 \mathrm{PGDH}$ in both cell types reflects a reduction in PPP in both cell types under the same conditions. Co-cultured neurons show a higher protein expression and protein activity, while astrocytes show a higher activity in the absence of 6PGDH mRNA changes. 
Henceforth, we tried to understand the possible relationship between mROS and glucose metabolism in co-cultured neurons under physiological $\mathrm{pO}_{2}$. First, we observed that in parallel to the significant increase in $\mathrm{O}_{2}-\mathrm{H}_{2} \mathrm{O}_{2}$ was significantly decreased. Even though these two ROS parameters seem to flow normally in the same sence, here the levels were controversial, suggesting that $\mathrm{O}_{2}-$ production was much higher than the detoxification capacity of the cells. Alternatively, the enzyme responsible of $\mathrm{O}_{2}{ }^{-}$conversion to $\mathrm{H}_{2} \mathrm{O}_{2}$ was in a lower expression level. Investigating the latter, we detected a very significant decrease in SOD2 expression under physiological $\mathrm{pO}_{2}$. Our results would have an explanation by the Reverse Electron Transport (RET), which is getting more importance over the last years. RET is produced when electrons from ubiquinol are transferred back to complex I, reducing $\mathrm{NAD}+$ to NADH. This process generates a significant amount of ROS (Lambert \& Brand, 2004). It is already known that RET occurs when the pool of coenzyme Q becomes overreduced with electrons from respiratory complex II (Chouchani et al., 2014) but also other complexes alterations (CIII and CIV) would also generate conditions for RET under low $\mathrm{O}_{2}$ conditions (Taylor \& Moncada, 2010).

In our resembling physiological $\mathrm{pO}_{2}$ model, co-cultured neurons have shown signs of maturity, both by reversing cell cycle phases, S and G0/G1, and by the transcriptomic data with a down-regulation of almost all proteins associated to cell cycle. Those data in addition to the overall results, indicate that $5 \% \mathrm{pO}_{2}$ is an optimal condition for cortical neurons and astrocytes cultures, since different concepts related to low $\mathrm{O}_{2}$ and toxicity have met in this work by different fashions, thus providing strong evidence for better survival and energy metabolism under physiological $\mathrm{O}_{2}$ conditions. 


\section{6- Conclusions}

At the light of the results presented in this Thesis, we have obtained the following conclusions:

1- Physiological $\mathrm{pO}_{2}(5 \%)$ improves the survival of neurons and astrocytes, reduce neuronal (but not astrocytic) mitochondrial $\Delta \psi \mathrm{m}$, and induces neuronal (but not astrocytic) mROS production.

2- Physiological $\mathrm{pO}_{2}(5 \%)$ induces a mitochondrial restructuration consisting of a dominant mitochondrial interconnection in astrocytes accompanied by reduced cristae maximal width and increased cristae density, in contrast with the fragmented mitochondria as the dominant form in neurons. Under these conditions, core regulator OPA1 is more expressed in astrocytes and presents a new isoforms pattern in neurons with increased $\mathrm{c}, \mathrm{d}$ and $\mathrm{e}$ isoforms, and reduction of $\mathrm{a}$ and $\mathrm{b}$ isoforms.

3- Physiological $\mathrm{pO}_{2}(5 \%)$ reduces mRNA expression of ETC and and OxPhos related genes in astrocytes and neurons.

4- Neurons co-cultured with astrocytes present higher free complex I levels, probably resulting in increased mROS production in these cells, a decreased F1 band associated to Complex V (ATP-syntase) alteration, and a shift in complex IV band. Neuronal, but not astrocytic, cell death was further reduced by the presence of astrocytes at physiological $\mathrm{pO}_{2}$. Only astrocytes reverted its $\Delta \psi_{\mathrm{m}}$ under these conditions by a significant depolarization.

5- Glucose metabolism was stimulated under physiological $\mathrm{pO}_{2}$, by an increased glucose consumption and lactate release in astrocytes, neurons, and co-cultured neurons. Glycolysis was increased in astrocytes, neurons and co-cultured neurons, but not in co-cultured astrocytes under these conditions. HIF-1 $\alpha$ does not appear to mediate these alterations, since its nuclear expression and activity was reduced, and confirmed by two different techniques.

6- The penthose phosphate pathway was also reduced, as judged by the majority of the PPP mRNA transcripts under physiological $\mathrm{pO}_{2}$ in co-cultured neurons.

7- While $\mathrm{O}_{2}-$ production is highly increased in co-cultured neurons under physiological $\mathrm{pO}_{2}$ conditions, $\mathrm{H}_{2} \mathrm{O}_{2}$ is significantly reduced. This is most probably due to the diminution of mitochondrial SOD2 protein expression.

8- Physiological $\mathrm{pO}_{2}$ drives co-cultured neurons to maturity by reverting $\mathrm{S}$ phase and G0/G1 phase. 
Overall, our results show that, when assessed at $\mathrm{pO}_{2}(5 \%)$ compatible with the $\mathrm{O}_{2}$ concentrations found in vivo tissue in close proximity with astrocytes, hence resembling a natural-like situation, neurons undergo a dramatic metabolic and redox adaptation that strongly differs from that observed at the non-physiological $\mathrm{pO}_{2}$ values $(21 \%)$. In general, these adaptations are responsible for a healthier situation as judged by the mitochondrial physiology, including ROS formation and $\Delta \psi_{\mathrm{m}}$, as well as by the survival rate. Our data also reveal that there is a highly active metabolic astrocyte-neuronal communication that contributes to the metabolic phenotype of neurons. Thus, caution should be taken when translating from culture conditions to the physiological situation the metabolic characterization of neurons. 


\section{7- Resumen en español}

\section{Introducción}

El cerebro de mamíferos es uno de los órganos más consumidores de energía, basándose sobre todo en el oxígeno molecular para mantener sus funciones. Los niveles de oxígeno (presión parcial de $\mathrm{O}_{2} \mathrm{O} \mathrm{pO}_{2}$ ) en el cerebro varían entre 1\% y $10 \%$ y representan los valores fisiológicos, mientras una disminución extrema o un aumento por encima de estos valores pueden resultar toxicos. Devor et al. (2011) demostraron que, dependiendo de la profundidad y de la distancia a las arterias, la $\mathrm{pO}_{2}$ en el tejido nervioso varía entre el $1 \% \mathrm{y}$ el $10,4 \%$.

Las disminuciones de aporte de oxígeno al cerebro, producen alteraciones e inducen sistemas de defensa y la apertura de vías de comunicación dentro de las células. El principal sistema de respuesta a la disminución de la disponibilidad de oxígeno es el formado por los HIFs (factores de transcripción inducibles por hipoxia) en el que destacan, sobre todo, las subunidades $\alpha$ de las isoformas HIF1 y HIF2. El aumento de la estabilidad de las subunidades $\alpha$ y su acumulación en el núcleo, en presencia de bajos niveles de oxígeno, induce la transcripción de varios genes diana, y la consiguiente cascada de reacciones que afectan a diversas vías metabólicas, entre ellas, la glucolisis, el metabolismo lipídico, la estructura del citoesqueleto, o la autofagia.

Tras los cambios de niveles de oxígeno, la mitocondria parece ser, de entre los orgánulos celulares, uno de los más afectados, mostrando alteraciones en la producción de especies reactivas de oxigeno (ROS), en la cadena transportadora de electrones (ETC) y cambios en la estructura y organización de los complejos y super-complejos mitochondriales (LopezFabuel et al., 2016). 


\section{Hipótesis y objetivos.}

\subsection{Hipótesis.}

Tradicionalmente, los cultivos primarios de células nerviosas se han realizado en condiciones ambientales estándar, típicas de la mayoría de los cultivos celulares, esto es: temperatura de $37^{\circ} \mathrm{C}$ y presiones parciales de oxígeno $\left(\mathrm{pO}_{2}\right)$ y de $\mathrm{CO}_{2}\left(\mathrm{pCO}_{2}\right)$ de $21 \%$ y $5 \%$ respectivamente. Sin embargo, aunque las condiciones de temperatura y $\mathrm{pCO}_{2}$ de los cultivos son próximas a la situación fisiológica en el tejido "in vivo", la $\mathrm{pO}_{2}$ utilizada en los cultivos está lejos de los niveles físiológicos, que oscilan entre el $1 \%$ y el $10 \%$ dependiendo de la distancia de las células a los capilares sanguíneos (Devor et al., 2011).

Dada la relación directa que existe entre las disponibilidades de oxígeno y el metabolismo oxidativo celular, creemos que el cambio de los niveles estándar de oxigeno hacia los niveles más fisiológicos $\left(\mathrm{pO}_{2}\right.$ entre el $1 \%$ al $\left.10 \%\right)$, para establecer las condiciones basales del cultivo, puede condicionar la respuesta a las alteraciones que reflejen estados patológicos y que puedan usarse como modelos. Por otro lado, la presencia de los astrocitos en estas condiciones, igualmente puede modular dicha respuesta aproximando los resultados del estudio a una situación más cercana a la fisiológica $\mathrm{y}$, por tanto, más adecuada para la investigación de enfermedades neurodegenerativas.

\subsection{Objetivos.}

En función de la hipótesis presentada los objetivos que nos planteamos para la presente Tesis Doctoral fueron:

(i) Caracterizar el fenotipo de neuronas y astrocitos a cultivados a diferentes presiones parciales de oxígeno, y definir la $\mathrm{pO}_{2}$ más próxima a la condición fisiológica de oxígeno.

(ii) Evaluar el metabolismo oxidativo en la condición fisiológica de oxígeno en comparación con la sobre-oxigenación de la condición estándar $\left(21 \% \mathrm{pO}_{2}\right)$ usada tradicionalmente en los cultivos.

(iii) Estudiar la influencia de otras células nerviosas en co-cultivo sobre los cambios observados en el metabolismo oxidativo de neuronas y en las condiciones anteriores.

(iv) Investigar los cambios que se produzcan en la estructura y el comportamiento mitocondrial en condiciones fisiológicas de oxígeno. 


\section{Resultados y Discusión}

\subsection{La $\mathrm{pO}_{2}$ fisiológica mejora la supervivencia y presenta efectos diferenciales sobre $\Delta \psi_{m}$ y la producción de mROS en neuronas y astrocitos}

Históricamente, los cultivos primarios de células nerviosas han sido realizados bajo condiciones ambientales estándares, típicas de la mayoría de los cultivos celulares y son: temperatura a $37^{\circ} \mathrm{C}$ y atmosfera con $21 \% \mathrm{pO}_{2}$ y $5 \% \mathrm{pCO}_{2}$. Sin embargo, aunque la temperatura estándar y pCO2 están cerca de la situación fisiológica en el tejido "in vivo", la $\mathrm{pO}_{2}$ atmosférica utilizada en los cultivos está lejos de los niveles fisiológicos, que oscilan entre $1 \%$ y $10 \%$ dependiendo de la distancia desde los capilares sanguíneos a las células (ver sección 1.1.1). Por lo tanto, no es irrazonable sospechar la existencia de niveles óptimos de $\mathrm{pO}_{2}$ para cultivar neuronas y astrocitos que se asemejen a su $\mathrm{pO}_{2}$ natural en el organismo. En nuestro estudio, para establecer el nivel óptimo de $\mathrm{pO}_{2}$, realizamos cultivos corticales primarios y cocultivos de neuronas y astrocitos de ratones a diferentes $\mathrm{pO}_{2}$ que oscilan del 1\% al 6\%, y al 21\%, utilizando como criterio de selección la muerte celular apoptótica, $\Delta \psi_{\mathrm{m}} \mathrm{y} \mathrm{mROS}$.

Se ha descrito que mROS y $\Delta \psi_{\mathrm{m}}$ se correlacionan inversamente en la hipoxia, y que la alta producción de mROS está estrechamente asociada con la apoptosis (Abramov et al., 2007; Angelova \& Abramov, 2018; Sullivan \& Chandel, 2014). Sin embargo, la apoptosis de astrocitos y neuronas, medida por citometría de flujo con anexina-V y 7AAD, disminuyó significativamente en ambos tipos de células después de cultivarlas durante 6 días a $5 \%$ y $6 \% \mathrm{pO}_{2}$, en comparación con los cultivos a $21 \% \mathrm{pO}_{2}$ (fig. 54 A y B). En las mismas condiciones, la producción de mROS aumentó en las neuronas, pero no experimentó cambios importantes en los astrocitos (fig. $54 \mathrm{E} \mathrm{y} \mathrm{F);} \mathrm{sin} \mathrm{embargo,} \mathrm{el} \Delta \psi_{\mathrm{m}}$ aumentó significativamente en astrocitos, pero se redujo en las neuronas (fig. 54 D y D). Además,

en el 5\% fisiológico de $\mathrm{pO}_{2}$, el análisis transcriptómico (fig. 32) indicó que los niveles de transcripción de los genes relacionados con ETC se redujeron en general en ambos tipos celulares. Tomados en conjunto, estos resultados indican que, en las neuronas, la disminución de la muerte apoptótica observada a concentraciones fisiológicas de oxígeno se asocia con la reducción en $\Delta \psi_{\mathrm{m}}$ y con el aumento de la producción de mROS. Cabe mencionar que el ARNm de UCP1 es el único transcrito que aumentó significativamente entre el resto de los genes relacionados con ETC en las neuronas (fig. 32a). Este resultado 
podría explicar la reducción en $\Delta \psi_{\mathrm{m}}$ en neuronas cultivadas al $5 \% \mathrm{pO}$. Es necesario señalar que el $5 \%$ de $\mathrm{pO}_{2}$ se encuentra dentro del rango de $\mathrm{pO}_{2}$ esperado en la corteza del cerebro de los ratones (Xu et al., 2017) y, por lo tanto, no se puede considerar como una situación hipóxica sino fisiológica. Por lo tanto, bajo nuestras condiciones experimentales, el aumento en la producción de mROS parece tener efectos positivos sobre la supervivencia neuronal. La relación entre la producción de mROS y la supervivencia neuronal durante la adaptación al 5\% de $\mathrm{pO}_{2}$ aún no se ha aclarado.

En astrocitos, dado que no hay cambios importantes en la producción de mROS, la reducción en la muerte apoptótica podría asociarse principalmente a mitocondrias altamente polarizadas (fig. 54). Debido a que no hay cambios en la expresión de proteínas desacopladas, como se ve en los resultados transcriptómicos (fig. 32b), el aumento en $\Delta \psi_{\mathrm{m}}$ podría ser el resultado de la reestructuración mitocondrial (fig. 55). Este aspecto se discutirá en la siguiente sección.

En co-cultivos, aunque la mera presencia de astrocitos mejoró la supervivencia neuronal en $\mathrm{pO}_{2}$ normóxica y físiológica, la incubación a $5 \%$ de $\mathrm{pO}_{2}$ redujo adicionalmente la apoptosis neuronal en aproximadamente 50\% (fig. 54G: barras rayadas), sin afectar significativamente la producción de $\Delta \psi_{\mathrm{m}}$ ni mROS (fig. I y K). Por el contrario, los astrocitos no se vieron afectados en los tres parámetros mencionados anteriormente. El análisis transcriptómico neuronal y astrocítico de los transcriptos de mRNA tanto de ETC como de OxPhos, en estas condiciones (fig. 36), reveló una reducción global en la transcripción de ETC y OxPhos y no mostró diferencias relevantes con las de las neuronas y los astrocitos cultivados solos. Por lo tanto, estos resultados sugieren que incubándose bajo $5 \%$ de $\mathrm{pO}_{2}$, las neuronas aumentan su tasa de supervivencia independientemente de la presencia de astrocitos, y que dicha mejora se correlaciona con la regulación negativa de la expresión génica relacionada con ETC y OxPhos.

Aunque la presencia de astrocitos aumentó considerablemente la supervivencia neuronal, entre otros efectos, está fuera de los objetivos de este trabajo, para poder analizar en profundidad los posibles cambios en el metabolismo de las neuronas y los astrocitos por la presencia del otro tipo de célula en el co-cultivo. 


\subsection{La $\mathrm{pO}_{2}$ fisiológica modula las formas mitocondriales y la organización estructural de los complejos ETC}

El estudio de la morfología mitocondrial bajo las diferentes concentraciones de oxígeno,

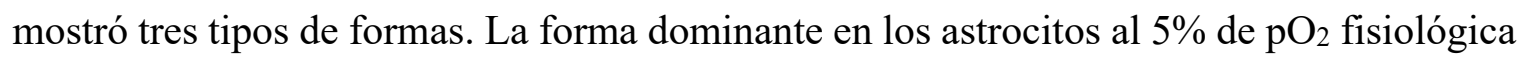
fueron las grandes redes interconectadas; sin embargo, en las neuronas, la forma dominante fue la mitocondria fragmentada. Las mitocondrias astrocíticas al 5\% de $\mathrm{pO}_{2}$ analizadas mediante microscopía electrónica mostraron un aumento en la red, orgánulos interconectados (fig. 55A) junto con una reducción significativa en el ancho de las crestas en comparación con el 21\% de $\mathrm{pO}_{2}$ (fig. 55B), de acuerdo con una mejor conservación de OPA1 (fig. 55F), que es clave para mantener el ensamblaje de los supercomplejos de la cadena respiratoria (Cogliati et al., 2013). En el $\mathrm{O}_{2}$ fisiológico encontrado en el cerebro (5\% $\mathrm{pO}_{2}$ ), las mitocondrias mostraron una morfología más alargadas, lo que proporcionaría una mejor superficie de crestas que albergaría más supercomplejos y así mejoraría la respiración cuando el $\mathrm{O}_{2}$ fuera bajo, evitando la apoptosis (Cogliati et al., 2013; Varanita et al., 2015). Sin embargo, el análisis transcriptómico (figs. 32 y 36) indicó una reducción en la expresión de los componentes de los complejos ETC y OxPhos, lo que sugiere, más bien, una reestructuración de los complejos respiratorios que un aumento en sus cantidades. De hecho, aumentó el número de crestas en las mitocondrias cuando los astrocitos se cultivaron a bajo $\mathrm{pO}_{2}$ fisiológica (5\%) (fig. 55C) confirmando así una tendencia hacia una conformación de ultra-estructura que soporta los grandes requisitos del estado respiratorio (Gomes et al., 2011).

Al estudiar los niveles de OPA1 (fig. 55F), observamos un aumento en las isoformas c, d y e con una reducción de las isoformas a y b en las neuronas. Esto podría deberse a una mayor expresión de la metaloendopeptidasa OMA1 que induce la escisión de las isoformas largas de OPA1, a y b, para dar lugar a las cortas (c, d y e). Por el contrario, los astrocitos cultivados al 5\% de $\mathrm{pO}_{2}$ mantienen el perfil de isoformas de OPA1 con un aumento en las cantidades detectadas de isoformas largas de OPA1. Esto podría significar un soporte fisiológico de los astrocitos para el metabolismo respiratorio y la señalización redox a las neuronas. Kim y colaboradores demostraron que las mitocondrias en células fibroblásticas de ratón, en hipoxia durante 24 horas, eran menos alargadas y más fragmentadas según la disponibilidad de AKAP121 (una proteína de soporte/andamiaje mitocondrial), lo que sugiere una remodelación mitocondrial inducida por hipoxia (H. Kim et al., 2011). Sin embargo, nuestros resultados en astrocitos muestran que la reducción de la disponibilidad 
de $\mathrm{O}_{2}$ del 21\% al 5\% promueve cambios mitocondriales en la dirección opuesta, es decir, hacia una forma más alargada e interconectada (fig. 55D), probablemente porque el 5\% de $\mathrm{pO}_{2}$ no puede considerarse hipóxico, pero sí una situación fisiológica. De hecho, tanto los astrocitos como las neuronas al $5 \%$ de $\mathrm{pO}_{2}$ mejoraron su supervivencia, lo que sugiere una utilización más eficiente de los recursos de energía, lo que está respaldado por la reestructuración observada de los complejos mitocondriales y supercomplejos neuronales (fig. 55G).

Por consiguiente, la organización de los complejos ETC se modificó en neuronas cocultivadas bajo $\mathrm{pO}_{2}$ fisiológica (5\%), mediante un aumento en el complejo I libre, una disminución en la banda $\mathrm{F} 1$ del complejo $\mathrm{V}$ y una modificación del peso molecular del complejo IV (fig. 55G). La cantidad incrementada en el complejo libre podría explicar el aumento de mROS observado en las neuronas bajo estas condiciones. La alteración del complejo V y el complejo IV, así como la reducción general en la expresión del ARNm de los genes relacionados con ETC y OxPhos (fig. 36) podría significar un cambio de la fosforilación oxidativa a un metabolismo más anaeróbico. En un contexto relacionado, Horvat et al. (2006) describieron un cambio en los niveles de expresión de las subunidades IV-1 y IV-2 del citocromo c oxidasa (COX IV-1 y COX IV-2) en las neuronas cerebelosas, un aumento en la COX IV-2 bajo condiciones de privación de $\mathrm{O}_{2}$. COX IV-1 es una subunidad reguladora responsable de la inhibición alostérica de la síntesis de ATP dependiente de éste, mientras que COX IV-2 carece de sensibilidad a ATP, por lo tanto, el cambio implica la abolición de la inhibición alostérica de COX por ATP. En nuestro caso, COX IV-2 no se detectó de acuerdo con el análisis transcriptómico de las proteínas relacionadas con ETC, pero la disminución significativa en la expresión astrocítica de la COX IV-1 (fig. 36b) podría apuntar en esta dirección. Por el contrario, no se observaron cambios significativos en la COX IV-1 en las neuronas. La reducción general en las expresiones de mRNA de las proteínas ETC y OxPhos, junto con los cambios en las estructuras de complejos y supercomplejos, sugiere un cambio hacia un metabolismo más anaeróbico que se analizará en el próximo apartado. Las relaciones entre los cambios en la expresión del ARNm de ETC y OxPhos y los cambios en las estructuras de supercomplejos merecen una investigación adicional. 


\subsection{Aumento del metabolismo glucídico en neuronas y astrocitos cultivados bajo $\mathrm{pO}_{2}$}

\section{fisiológica}

Las neuronas y los astrocitos cultivados por separado a un 5\% de $\mathrm{pO}_{2}$ muestran aumentos significativos en el consumo de glucosa y la acumulación de lactato en comparación con el $21 \%$ de $\mathrm{pO}_{2}$. Este aumento fue concordante con la expresión aumentada de transcritos de ARNm relacionados con la glucólisis como se manifiesta en el análisis transcriptómico (fig. 38). Estos resultados apoyan claramente un cambio hacia un metabolismo anaeróbico en ambos tipos celulares, como se ha señalado en el apartado anterior. Cabe decir que la expresión del ARNm del transportador de glucosa GLUT1 (gen Slc2a1) en las neuronas aumenta aproximadamente 27 veces tras la incubación al 5\% de $\mathrm{pO}_{2}$. Este aumento en el nivel de expresión de GLUT1 puede ser una adaptación ambiental a la glucosa en el medio (Maher et al., 1996). Sin embargo, las muestras se obtuvieron de cultivos al 21\% y 5\% de $\mathrm{pO}_{2}, 24$ horas después de cambiar el medio de cultivo, por lo tanto, es poco probable que las diferencias en la glucosa sean responsables de dicho aumento en la expresión de GLUT1. También se debe mencionar que el análisis transcriptómico muestra un aumento de 4,2 veces en las neuronas del ARNm de la proteína activadora de la glicólisis PFKFB3, después de la incubación con $5 \%$ de $\mathrm{pO}_{2}$, lo que indica una activación verosímil fuerte de la ruta glucolítica. Herrero-Mendez et al. en 2009 describieron que aunque el ARNm de PFKFB3 estaba presente en neuronas cultivadas al $21 \%$ de $\mathrm{pO}_{2}$, el contenido proteico era despreciable debido a su degradación proteasómica continua mediada por APC/C-Cdh1. Nuestros resultados mostraron que la actividad glucolítica neuronal y astrocítica aumentó aproximadamente dos veces al cultivar las células al 5\% pO (fig. 56 A y B), sugiriendo la aparición de otra forma de regulación de PFKFB3 a nivel transcripcional.

De acuerdo con los datos obtenidos en mono-cultivos, las incubaciones de co-cultivos de neuronas/astrocitos en $\mathrm{pO}_{2}$ fisiológica (5\%) aumentaron significativamente la expresión de casi todos los genes glucolíticos en neuronas, pero no en astrocitos, como se puede observar en el esquema transcriptómico (fig. 40). Estos resultados transcriptómicos se confirmaron parcialmente mediante análisis Western blot de la expresión de la proteína Hexokinase II (HKII), que se incrementó significativamente (fig. 56E). La HKII es responsable del primer paso de la cascada glucolítica y de uno de los tres pasos limitantes de la ruta, por lo que se puede utilizar como un buen ejemplo de la actividad de la vía. El análisis transcriptómico también mostró que la expresión del ARNm de PFKFB3 aumentaba solo en las neuronas, pero no en los astrocitos (resultados no mostrados). Todos estos datos se confirmaron 
mediante la determinación de las velocidades glucolíticas como se representa en la fig. 56 $\mathrm{C}$ y D, donde observamos un aumento significativo en las neuronas co-cultivadas pero no en los astrocitos co-cultivados.

Dado que los astrocitos co-cultivados no mostraron ningún cambio en la actividad glucolítica, decidimos centrar nuestra atención en la respuesta metabólica de las neuronas co-cultivadas a $\mathrm{pO}_{2}$ físiológica del $5 \%$. Por lo tanto, a continuación, tratamos de estudiar en profundidad el mecanismo responsable de la inducción glucolítica.

Dada la relación entre los HIFs y la disponibilidad de $\mathrm{O}_{2}$ (ver sección 1.1.5.1), decidimos investigar la implicación de HIF-1 $\alpha$ en la adaptación metabólica neuronal al $5 \% \mathrm{pO}_{2}$ en comparación con la estándar $21 \% \mathrm{pO}_{2}$. En contraste con lo que se esperaba, el análisis de Western blot mostró que bajo la condición del $5 \%$ de $\mathrm{pO}_{2}$, se redujo significativamente el contenido nuclear de HIF-1 $\alpha$ (fig. 56 F). Este resultado fue confirmado por el ensayo de actividad HRE-luciferasa (fig. 56 G) que mostró una disminución muy significativa en la fluorescencia que refleja la baja actividad de HIF-1 $\alpha$ en núcleos de neuronas co-cultivadas. Considerando todo lo dicho anteriormente, estos resultados sugirieron claramente que cuando las neuronas están expuestas crónicamente al 5\% de $\mathrm{pO}_{2}, \mathrm{HIF}-1 \alpha$ no parece ser el regulador de la glucólisis.

Recientemente, revisando los mecanismos no canónicos que regulan HIF-1 $\alpha$ en el cáncer, Iommarini et al. (2017), observaron una desestabilización de HIF-1 $\alpha$ en condiciones de baja $\mathrm{pO}_{2}$ debido a inhibiciones de la actividad de ETC, con el consiguiente aumento de la $\mathrm{pO}_{2}$ intracelular. Por lo tanto, causó pseudo-normoxia y activación del sistema de control Prolil-hidroxilasa. Siempre que este fuera el caso en nuestras condiciones, la reducción observada en los niveles de expresión de los ARNm de proteína ETC y OxPhos relacionados (fig. 40) podría ser responsable de la regulación negativa de HIF-1 $\alpha$.

También analizamos, mediante RT-qPCR, el contenido celular de CPT1a, un gen diana de HIF-1, que se encontró que disminuía significativamente en estas condiciones (fig. 57H). Dado que la expresión de CPT1 está directamente reprimida por HIF-1 $\alpha$, la reducción observada en el contenido de mRNA de CPT1a podría estar mediada por otros factores de transcripción, diferentes de HIF-1 $\alpha$. Además, esta hipótesis queda por dilucidar por completo.

Dado que HIF-1 $\alpha$ y la proteína-quinasa dependiente de AMP (AMPK) son vías interconectadas (Lee et al., 2010 , ver sección 1.1.5.6), y AMPK es uno de los principales 
reguladores del metabolismo energético, se intentó investigar si AMPK podría estar involucrada en el comportamiento metabólico de las neuronas co-cultivadas al 5\% pO2. El análisis de AMPK y pAMPK mostró una disminución en la tasa de fosforilación (fig. $56 \mathrm{H}$ e I) de esta enzima al 5\% de $\mathrm{pO}_{2}$. A continuación, corroboramos los efectos observados en AMPK mediante Western blot las cantidades celulares de ACC1 y fosfo-ACC1 (fig. $56 \mathrm{~J}$ y K). ACC1 es la enzima limitante de la velocidad de la síntesis de ácidos grasos y está fosforilada (y desactivada) por AMPK. La disminución significativa observada en la tasa de la fosforilación de $\mathrm{ACC}$ ( $\mathrm{pACC} 1 / \mathrm{ACC} 1)$ bajo $\mathrm{pO}_{2}$ fisiológica indicó una reducción de la actividad de AMPK y sugirió una estimulación de la biosíntesis de ácidos grasos. Estos resultados indican una actividad reducida de AMPK y sugiere que los requisitos de energía de las neuronas co-cultivadas se cumplieron bajo $\mathrm{pO}_{2}$ fisiológica. Además, Emerling y colaboradores (2009) describieron que la activación de AMPK en condiciones hipóxicas (1.5\% pO2) depende de la producción de mROS en lugar de un aumento en los niveles de AMP.

\subsection{Reducción de PPP y producción diferencial de $\mathrm{mROS}$ y $\mathrm{H}_{2} \mathrm{O}_{2}$ bajo p $\mathrm{O}_{2}$ fisiológica}

El análisis de glucólisis mostró un aumento significativo en las neuronas co-cultivadas, pero no en los astrocitos. Dada la estrecha conexión entre la glucólisis y la PPP, nos llevó a verificar los cambios que ocurran bajo las mismas condiciones fisiológicas de $\mathrm{pO}_{2}$. El estudio transcriptómico reveló una reducción significativa en la expresión de transaldolasa y 6-fosfogluconato deshidrogenasa (fig. 57 A). Investigamos la expresión y actividad de la proteína 6PGDH en neuronas y astrocitos co-cultivados bajo la $\mathrm{pO}_{2}$ físiológica, $\mathrm{y}$ detectamos una disminución significativa en la actividad de la proteína en ambas células (fig. 57 B y C), pero solo una disminución significativa en la expresión de proteínas en las neuronas co-cultivadas (fig. 57 D). La reducción significativa de 6PGDH en ambos tipos de células reflejó una reducción en PPP en ambos tipos de células en las mismas condiciones. Las neuronas co-cultivadas mostraron una mayor expresión de proteínas y actividad proteica, mientras que los astrocitos manifestaron una mayor actividad en ausencia de cambios en el ARNm de 6PGDH.

De ahora en adelante, tratamos de comprender la posible relación entre mROS y el metabolismo glucídico en neuronas co-cultivadas bajo $\mathrm{pO}_{2}$ fisiológica. En primer lugar, observamos que, en paralelo con el aumento significativo de $\mathrm{O} 2 \cdot^{-}$, el $\mathrm{H}_{2} \mathrm{O}_{2}$ se redujo significativamente (fig. $57 \mathrm{E} \mathrm{y} \mathrm{F).} \mathrm{Aunque} \mathrm{estos} \mathrm{dos} \mathrm{parámetros} \mathrm{de} \mathrm{ROS} \mathrm{parecen} \mathrm{fluir}$ 
normalmente en el mismo sentido, aquí los niveles fueron controvertidos, lo que sugirió que la producción de O2.- era mucho más alta que la capacidad de desintoxicación de las células. Alternativamente, la enzima responsable de la conversión de $\mathrm{O} 2{ }^{-}$a $\mathrm{H}_{2} \mathrm{O}_{2}$ estaba en un nivel de expresión más bajo. Investigando este último, detectamos una disminución muy significativa en la expresión de $\mathrm{SOD} 2$ en $\mathrm{pO}_{2}$ fisiológica (fig. $57 \mathrm{G}$ ). Nuestros resultados podrían tener una explicación por el Transporte Reverso de Electrones (RET), que está adquiriendo mayor relevancia en los últimos años. El RET se produce cuando los electrones de ubiquinol se transfieren de nuevo al complejo I, reduciendo NAD + a NADH. Este proceso genera una cantidad significativa de ROS (Lambert \& Brand, 2004). Ya se sabe que RET ocurre cuando el conjunto de la coenzima $\mathrm{Q}$ se reduce demasiado con electrones del complejo respiratorio II (Chouchani et al., 2014), pero también otras alteraciones de complejos (CIII y CIV) generarían condiciones para RET a bajos niveles de $\mathrm{pO}_{2}$ (Taylor \& Moncada, 2010).

En nuestro modelo de $\mathrm{pO}_{2}$ similar a la fisiológica, las neuronas co-cultivadas han mostrado signos de madurez, tanto al invertir las fases del ciclo celular, S y G0 / G1, como por los datos transcriptómicos con una regulación negativa de casi todas las proteínas asociadas al ciclo celular. Esos datos, además de los resultados generales, indican que el 5\% de $\mathrm{pO}_{2}$ es una condición óptima para los cultivos de neuronas corticales y astrocitos.

Dado que en este trabajo hemos obtenido, mediante varios métodos, diferentes conceptos relacionados con un nivel bajo de $\mathrm{O}_{2}$ y la toxicidad, en condiciones físiológicas de $\mathrm{O}_{2}$, proporcionamos una evidencia fuerte de una mejor supervivencia y metabolismo energético. 
A

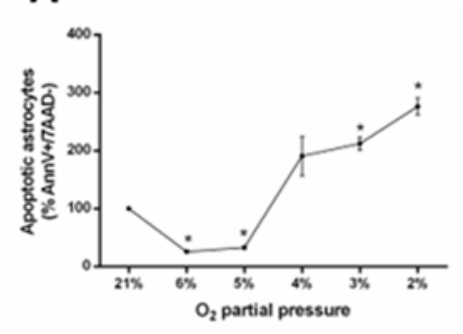

D
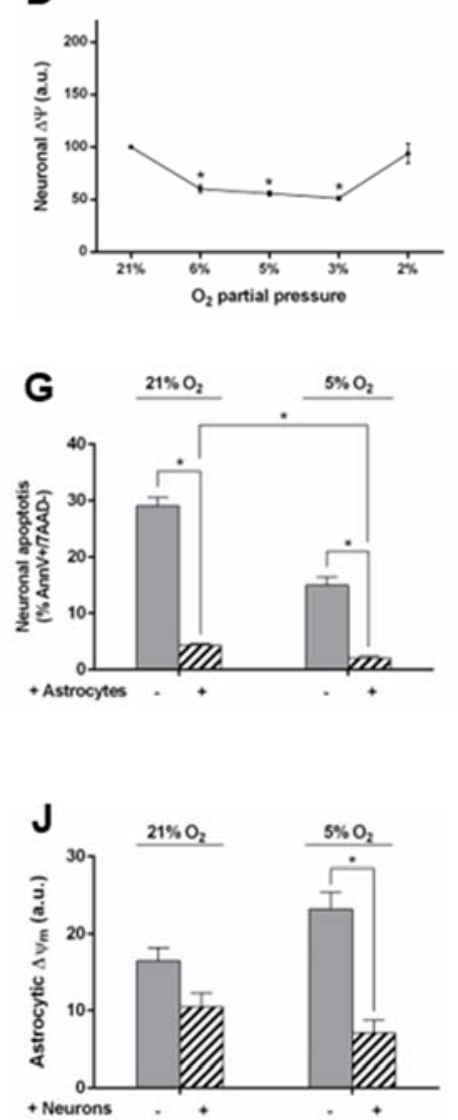

B

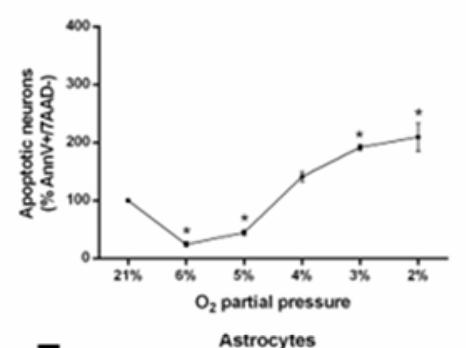

E Mitochondrial ROS (Mitosox ${ }^{\circ}$ )
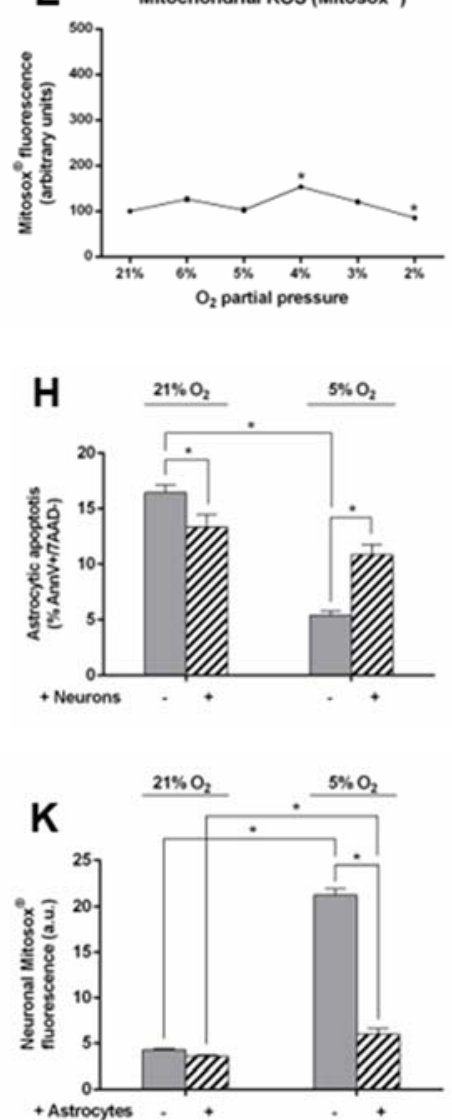

C
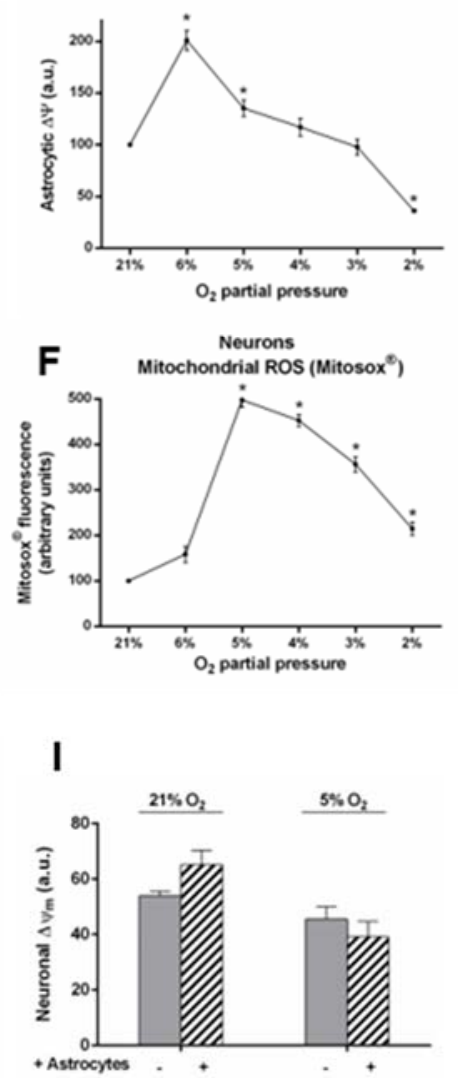

L $\quad \stackrel{21 \mathrm{KO}_{2}}{\quad} \quad \stackrel{5 \mathrm{NO}_{2}}{\longrightarrow}$

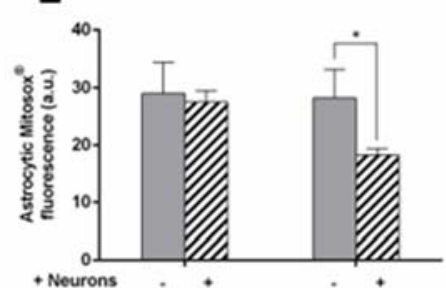

Figure 54. Efectos de la pO $\mathrm{O}_{2}$ fisiológica sobre los cultivos 

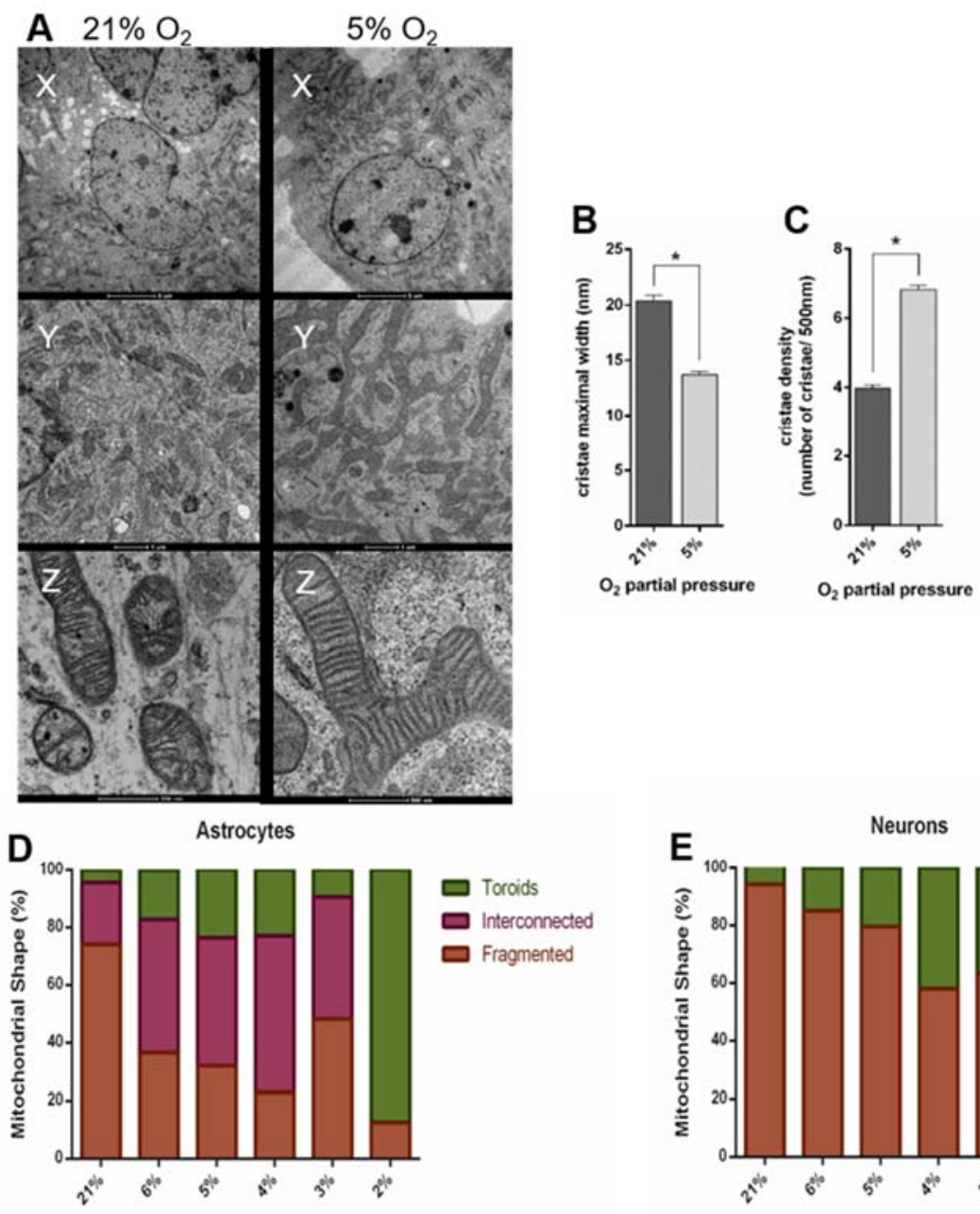

$\mathbf{F}$
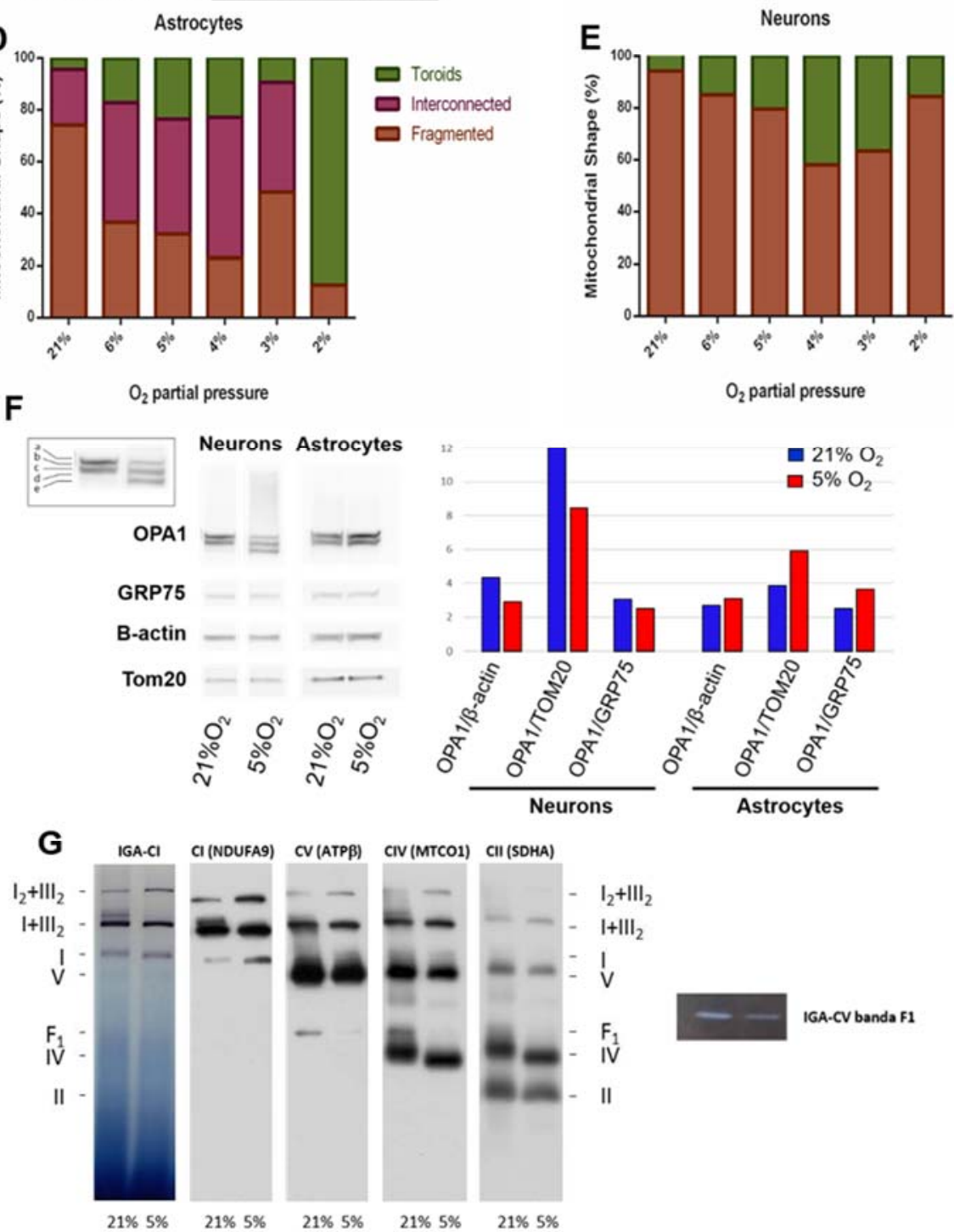

Figura 55. Efectos de la $\mathrm{pO}_{2}$ fisiológica sobre la estructura de la mitocondria y de la cadena respiratoria 
A
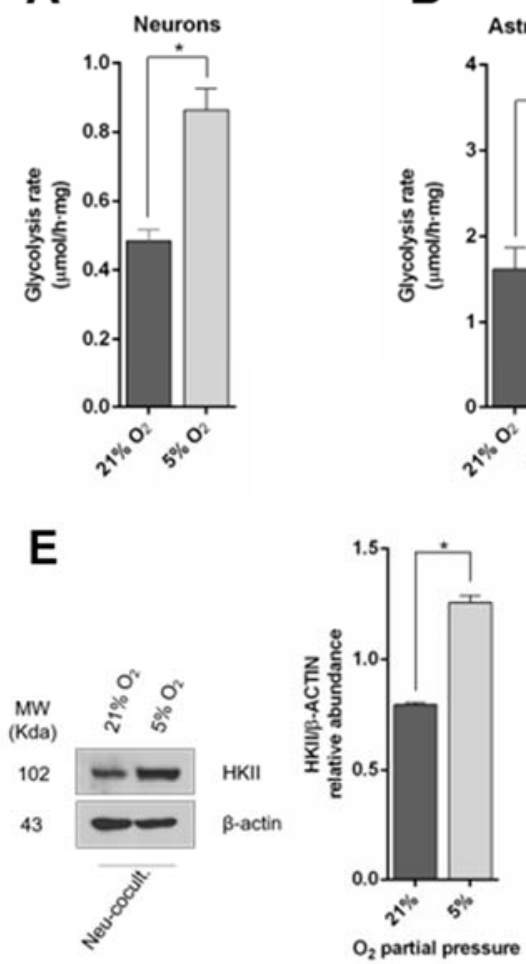

B

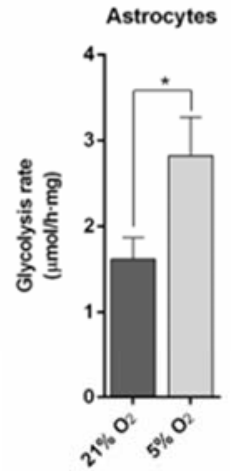

C

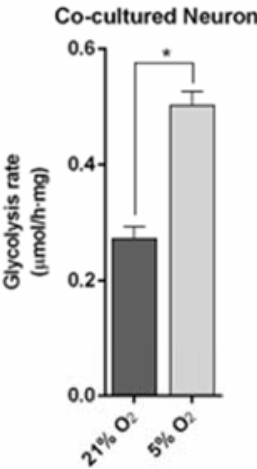

D

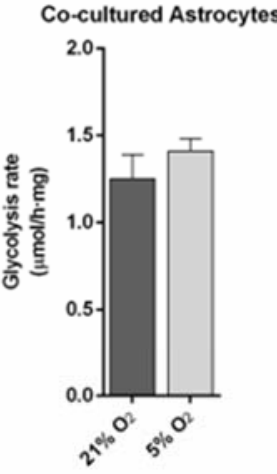

H
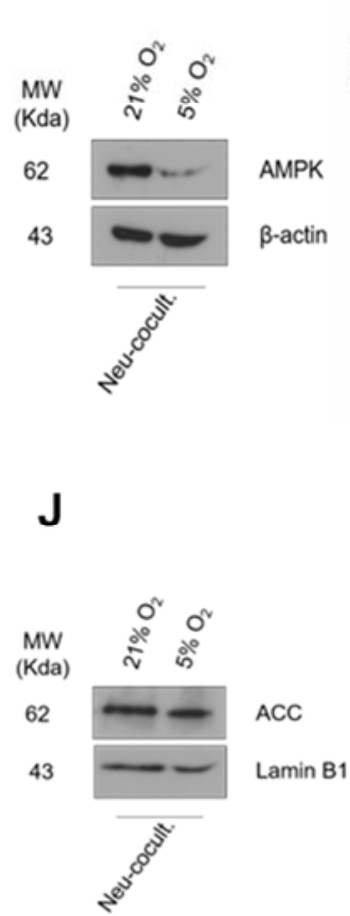

$\mathbf{F}$
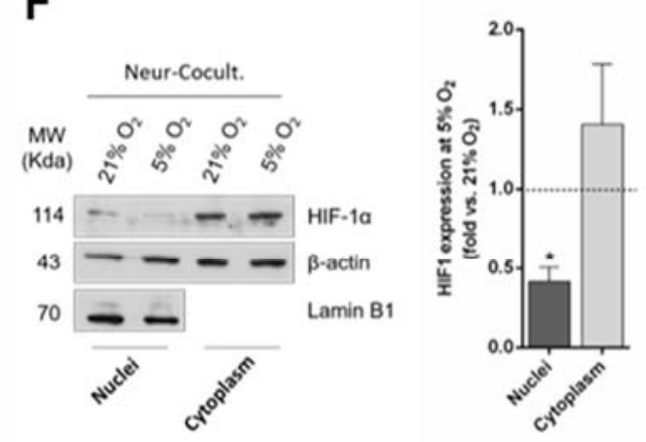

G

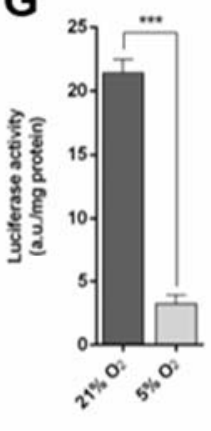

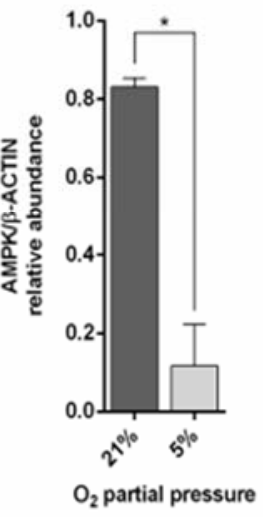
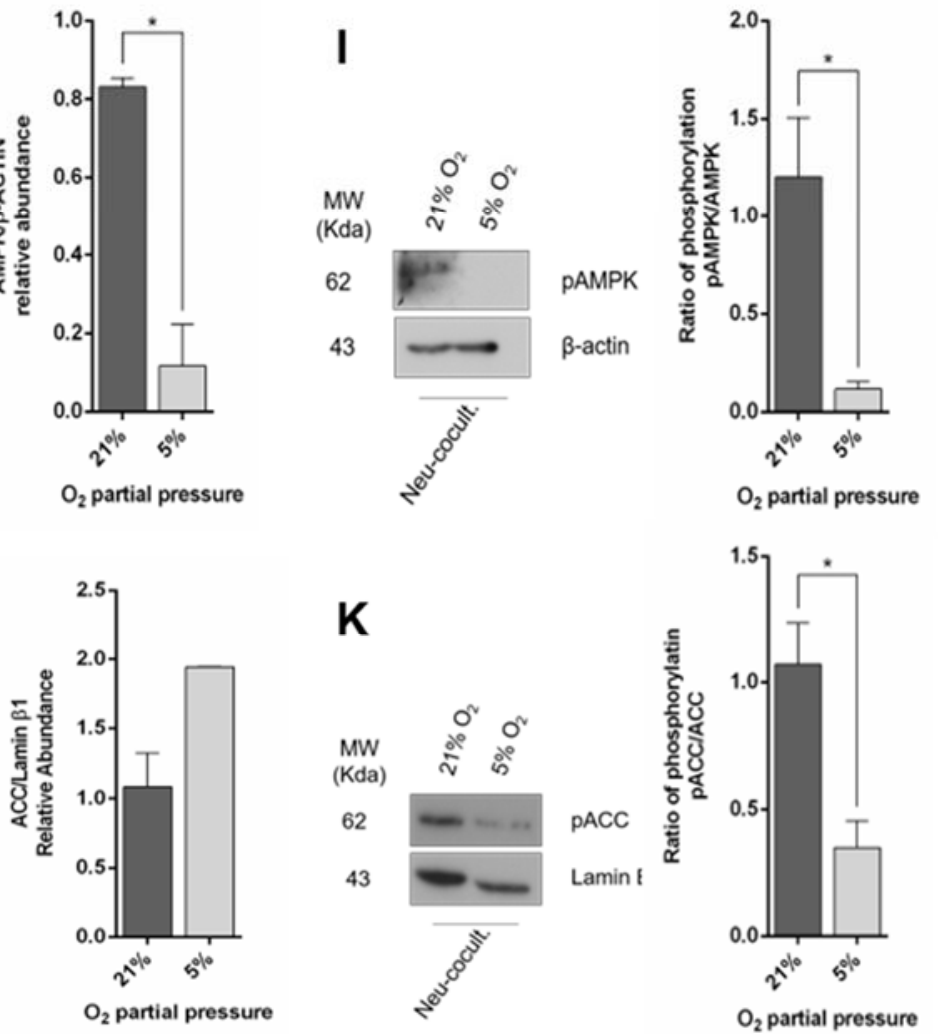

Figura 56. Efectos de la $\mathrm{pO}_{2}$ fisiológica sobre la glucólisis y su regulación, en neuronas en co-cultivos 

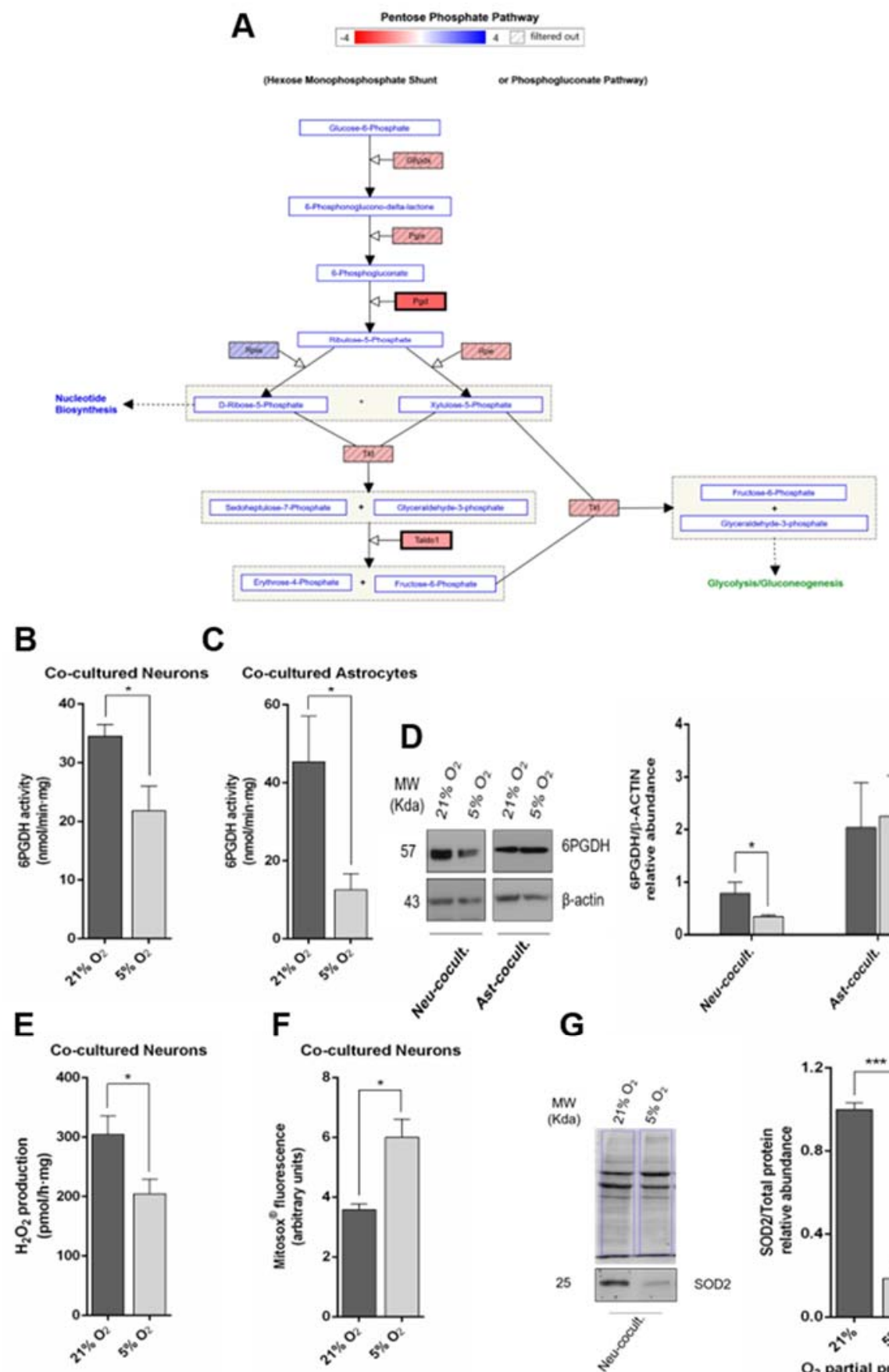

C

Co-cultured Astrocytes

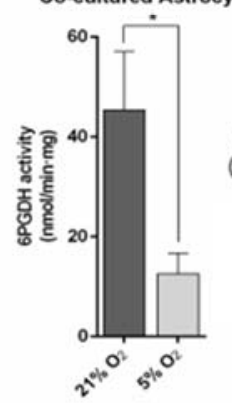

F

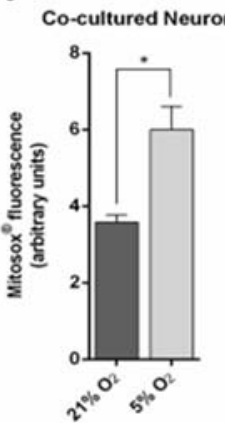

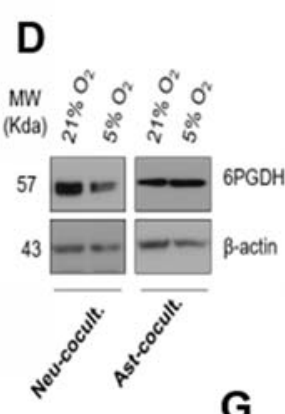

G

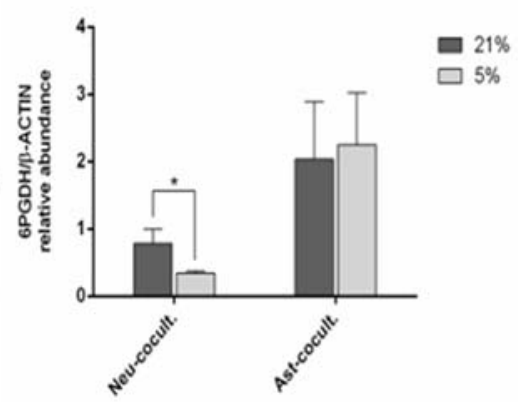

$\square 21 \%$
$\square 5 \%$

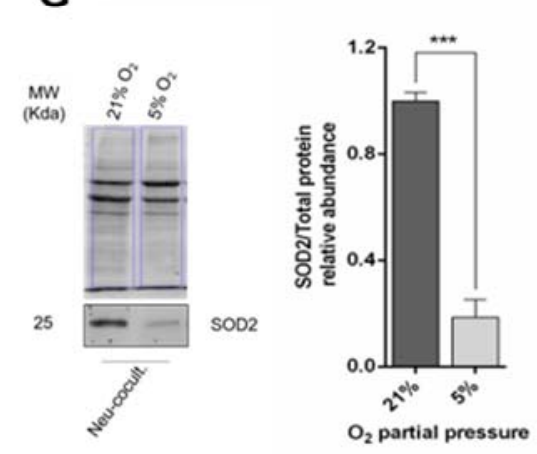

H RT-qPCR

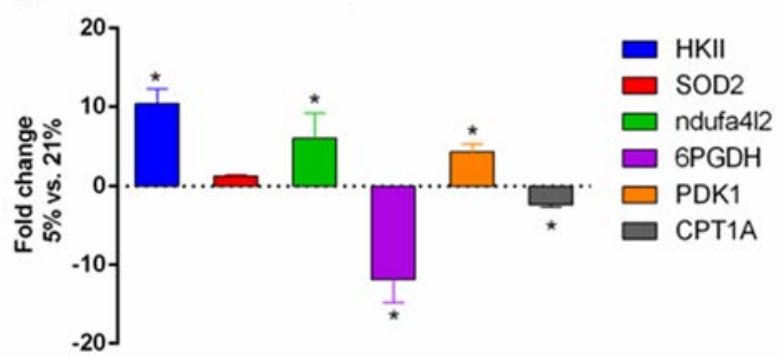

Figura 57. Efectos de $\mathrm{pO}_{2}$ fisiológica sobre la PPP y sobre los mROS 


\section{Conclusiones}

A la vista de los resultados presentados en esta Tesis Doctoral, se obtuvieron las siguientes conclusiones:

1- $\mathrm{La} \mathrm{pO}_{2}$ fisiológica (5\%) mejora la supervivencia de las neuronas y los astrocitos, reduce el $\Delta \psi_{\mathrm{m}}$ mitocondrial neuronal (pero no astrocítico) e induce la producción de mROS neuronal (pero no astrocítica).

2- $\mathrm{La} \mathrm{pO}_{2}$ fisiológica (5\%) induce una reestructuración mitocondrial que consiste en una interconexión mitocondrial dominante en astrocitos acompañada de una reducción en la anchura de las crestas y una mayor densidad en su número, en contraste con las mitocondrias fragmentadas como forma dominante en las neuronas. En estas condiciones, el regulador central OPA1 se expresa más en astrocitos y presenta un nuevo patrón de isoformas en las neuronas con isoformas c, d y e incrementadas, y la reducción de las isoformas a y b.

3- La $\mathrm{pO}_{2}$ fisiológica (5\%) reduce la expresión de $\mathrm{ARNm}$ de los genes relacionados con ETC y OxPhos en astrocitos y neuronas.

4- Las neuronas co-cultivadas con astrocitos presentan mayores niveles de complejo I libre, lo que probablemente resulte en una mayor producción de mROS en estas células, una disminución de la banda $\mathrm{F} 1$ asociada a la alteración del complejo $\mathrm{V}$ (ATP-sintasa) y un cambio del peso molecular del complejo IV. La muerte celular neuronal, pero no astrocítica, se redujo aún más por la presencia de astrocitos en la $\mathrm{pO}_{2}$ fisiológica. Solo los astrocitos revirtieron su $\Delta \psi_{\mathrm{m}}$ bajo estas condiciones por una despolarización significativa.

5- El metabolismo glucídico se estimuló bajo $\mathrm{pO}_{2}$ físiológica, por un aumento en el consumo de glucosa y una liberación de lactato en astrocitos, neuronas y neuronas co-cultivadas. La glucólisis se incrementó en astrocitos, neuronas y neuronas cocultivadas, pero no en astrocitos co-cultivados en estas condiciones. HIF-1 $\alpha$ no parece mediar en estas alteraciones, ya que su expresión y actividad nucleares se redujeron y se confirmaron mediante dos técnicas diferentes.

6- La vía de la pentosa fosfato también se redujo, según se mostró por la mayoría de los transcritos de ARNm de PPP bajo $\mathrm{pO}_{2}$ fisiológica en neuronas co-cultivadas. 
7- Mientras que la producción de O2-- está muy aumentada en las neuronas cocultivadas en condiciones de $\mathrm{pO}_{2}$ fisiológica, el $\mathrm{H}_{2} \mathrm{O}_{2}$ se reduce significativamente. Esto es muy probable que se deba a la disminución de la expresión mitocondrial de la proteína SOD2.

8- $\mathrm{La} \mathrm{pO}_{2}$ fisiológica impulsa las neuronas co-cultivadas a la madurez al revertir la fase S y la fase G0 / G1.

En general, nuestros resultados muestran que, cuando se evalúa en $\mathrm{pO}_{2}(5 \%)$ compatible con las concentraciones de $\mathrm{O}_{2}$ encontradas en tejido vivo en estrecha proximidad con astrocitos, por lo que se asemeja a una situación natural, las neuronas experimentan una dramática adaptación metabólica y redox que difiere fuertemente de lo observado en los valores de $\mathrm{pO}_{2}$ no fisiológica (21\%). En general, estas adaptaciones son responsables de una situación más saludable según lo juzgado por la fisiología mitocondrial, incluida la formación de ROS y $\Delta \psi \mathrm{m}$, así como por la tasa de supervivencia. Nuestros datos también revelan que existe una comunicación metabólica astrocítica-neuronal altamente activa que contribuye al fenotipo metabólico de las neuronas. Por lo tanto, al realizar la caracterización metabólica de las neuronas, se debe tener precaución al trasladar de las condiciones de cultivo a la situación fisiológica. 


\section{REFERENCES}

Abramov, A. Y., Scorziello, A., \& Duchen, M. R. (2007). Three distinct mechanisms generate oxygen free radicals in neurons and contribute to cell death during anoxia and reoxygenation. J Neurosci, 27(5), 1129-1138. doi:10.1523/jneurosci.4468-06.2007

Acin-Perez, R., Bayona-Bafaluy, M. P., Fernandez-Silva, P., Moreno-Loshuertos, R., Perez-Martos, A., Bruno, C., . . Enriquez, J. A. (2004). Respiratory complex III is required to maintain complex I in mammalian mitochondria. Mol Cell, 13(6), 805-815.

Acin-Perez, R., Fernandez-Silva, P., Peleato, M. L., Perez-Martos, A., \& Enriquez, J. A. (2008). Respiratory active mitochondrial supercomplexes. Mol Cell, 32(4), 529-539. doi:10.1016/j.molcel.2008.10.021

Adriani, G., Ma, D., Pavesi, A., Kamm, R. D., \& Goh, E. L. (2017). A 3D neurovascular microfluidic model consisting of neurons, astrocytes and cerebral endothelial cells as a blood-brain barrier. Lab Chip, 17(3), 448-459. doi:10.1039/c6lc00638h

Ahmadinejad, F., Geir Moller, S., Hashemzadeh-Chaleshtori, M., Bidkhori, G., \& Jami, M. S. (2017). Molecular Mechanisms behind Free Radical Scavengers Function against Oxidative Stress. Antioxidants (Basel), 6(3). doi:10.3390/antiox6030051

Ainslie, P. N., \& Poulin, M. J. (2004). Ventilatory, cerebrovascular, and cardiovascular interactions in acute hypoxia: regulation by carbon dioxide. J Appl Physiol (1985), 97(1), 149-159. doi:10.1152/japplphysiol.01385.2003

Al-Kafaji, G., Sabry, M. A., \& Skrypnyk, C. (2015). Time-course effect of high glucoseinduced reactive oxygen species on mitochondrial biogenesis and function in human renal mesangial cells. Cell Biol Int. doi:10.1002/cbin.10520

Almeida, A., Bolanos, J. P., \& Moreno, S. (2005). Cdh1/Hct1-APC is essential for the survival of postmitotic neurons. $J$ Neurosci, 25(36), 8115-8121. doi:10.1523/jneurosci.1143-05.2005

Almeida, A., \& Medina, J. M. (1998). A rapid method for the isolation of metabolically active mitochondria from rat neurons and astrocytes in primary culture. Brain Res Brain Res Protoc, 2(3), 209-214. 
Almeida, A., Moncada, S., \& Bolanos, J. P. (2004). Nitric oxide switches on glycolysis through the AMP protein kinase and 6-phosphofructo-2-kinase pathway. Nat Cell Biol, 6(1), 45-51. doi: $10.1038 / \mathrm{ncb} 1080$

Althoff, T., Mills, D. J., Popot, J. L., \& Kuhlbrandt, W. (2011). Arrangement of electron transport chain components in bovine mitochondrial supercomplex I1III2IV1. Embo $j$, 30(22), 4652-4664. doi:10.1038/emboj.2011.324

Angelova, P. R., \& Abramov, A. Y. (2018). Role of mitochondrial ROS in the brain: from physiology to neurodegeneration. FEBS Lett, 592(5), 692-702. doi:10.1002/18733468.12964

Angelova, P. R., Kasymov, V., Christie, I., Sheikhbahaei, S., Turovsky, E., Marina, N., .. . Gourine, A. V. (2015). Functional Oxygen Sensitivity of Astrocytes. J Neurosci, 35(29), 10460-10473. doi:10.1523/JNEUROSCI.0045-15.2015

Aouacheria, A., Baghdiguian, S., Lamb, H. M., Huska, J. D., Pineda, F. J., \& Hardwick, J. M. (2017). Connecting mitochondrial dynamics and life-or-death events via Bcl-2 family proteins. Neurochem Int. doi:10.1016/j.neuint.2017.04.009

Arany, Z., Huang, L. E., Eckner, R., Bhattacharya, S., Jiang, C., Goldberg, M. A., . . . Livingston, D. M. (1996). An essential role for p300/CBP in the cellular response to hypoxia. Proc Natl Acad Sci U S A, 93(23), 12969-12973.

Aras, S., Bai, M., Lee, I., Springett, R., Huttemann, M., \& Grossman, L. I. (2015). MNRR1 (formerly CHCHD2) is a bi-organellar regulator of mitochondrial metabolism. Mitochondrion, 20, 43-51. doi:10.1016/j.mito.2014.10.003

Ashrafi, G., \& Ryan, T. A. (2017). Glucose metabolism in nerve terminals. Curr Opin Neurobiol, 45, 156-161. doi:10.1016/j.conb.2017.03.007

Baehner, R. L., Murrmann, S. K., Davis, J., \& Johnston, R. B., Jr. (1975). The role of superoxide anion and hydrogen peroxide in phagocytosis-associated oxidative metabolic reactions. J Clin Invest, 56(3), 571-576. doi:10.1172/jci108126

Barker, J. E., Bolanos, J. P., Land, J. M., Clark, J. B., \& Heales, S. J. (1996). Glutathione protects astrocytes from peroxynitrite-mediated mitochondrial damage: implications for 
neuronal/astrocytic trafficking and neurodegeneration. Dev Neurosci, 18(5-6), 391-396. doi:10.1159/000111432

Barsoum, M. J., Yuan, H., Gerencser, A. A., Liot, G., Kushnareva, Y., Graber, S., . . . Bossy-Wetzel, E. (2006). Nitric oxide-induced mitochondrial fission is regulated by dynamin-related GTPases in neurons. Embo j, 25(16), 3900-3911. doi:10.1038/sj.emboj.7601253

Bergmeyer, H. U., Bernt, E., Schmidt, F., \& Stork, H. (1974). Determination with hexokinase and glucoses-phosphate dehydrogenase. In W. Verlag Chemie GmbH (Ed.), Methods of Enzymatic Analysis (pp. 1196-1201).

Berridge, M. V., McConnell, M. J., Grasso, C., Bajzikova, M., Kovarova, J., \& Neuzil, J. (2016). Horizontal transfer of mitochondria between mammalian cells: beyond co-culture approaches. Curr Opin Genet Dev, 38, 75-82. doi:10.1016/j.gde.2016.04.003

Bezawork-Geleta, A., Rohlena, J., Dong, L., Pacak, K., \& Neuzil, J. (2017). Mitochondrial Complex II: At the Crossroads. Trends Biochem Sci, 42(4), 312-325. doi:10.1016/j.tibs.2017.01.003

Bhola, P. D., \& Letai, A. (2016). Mitochondria-Judges and Executioners of Cell Death Sentences. Mol Cell, 61(5), 695-704. doi:10.1016/j.molcel.2016.02.019

Bianchi, C., Genova, M. L., Parenti Castelli, G., \& Lenaz, G. (2004). The mitochondrial respiratory chain is partially organized in a supercomplex assembly: kinetic evidence using flux control analysis. $J$ Biol Chem, 279(35), 36562-36569. doi:10.1074/jbc.M405135200

Biosystems, A. (2008). Guide to Performing Relative Quantitation of Gene Expression Using Real-Time Quantitative PCR.

Blanco, V. M., Stern, J. E., \& Filosa, J. A. (2008). Tone-dependent vascular responses to astrocyte-derived signals. Am J Physiol Heart Circ Physiol, 294(6), H2855-2863. doi:10.1152/ajpheart.91451.2007

Blondin, G. A., \& Green, D. E. (1967). The mechanism of mitochondrial swelling. Proc Natl Acad Sci U S A, 58(2), 612-619. 
Bojes, H. K., Datta, K., Xu, J., Chin, A., Simonian, P., Nunez, G., \& Kehrer, J. P. (1997). Bcl-xL overexpression attenuates glutathione depletion in FL5.12 cells following interleukin-3 withdrawal. Biochem J, 325 ( Pt 2), 315-319.

Bolanos, J. P. (2016). Bioenergetics and redox adaptations of astrocytes to neuronal activity. J Neurochem, 139 Suppl 2, 115-125. doi:10.1111/jnc.13486

Bolanos, J. P., Almeida, A., \& Moncada, S. (2010). Glycolysis: a bioenergetic or a survival pathway? Trends Biochem Sci, 35(3), 145-149. doi:10.1016/j.tibs.2009.10.006

Bolanos, J. P., Peuchen, S., Heales, S. J., Land, J. M., \& Clark, J. B. (1994). Nitric oxidemediated inhibition of the mitochondrial respiratory chain in cultured astrocytes. $J$ Neurochem, 63(3), 910-916.

Bonora, M., Morganti, C., Morciano, G., Giorgi, C., Wieckowski, M. R., \& Pinton, P. (2016). Comprehensive analysis of mitochondrial permeability transition pore activity in living cells using fluorescence-imaging-based techniques. Nat Protoc, 11(6), 1067-1080. doi:10.1038/nprot.2016.064

Borek, A., Ekiert, R., \& Osyczka, A. (2016). [Molecular effects of mitochondrial mutations in cytochrome $\mathrm{b}$ of complex III and their impact on the levels of free radical production]. Postepy Biochem, 62(2), 162-172.

Bright, J., \& Khar, A. (1994). Apoptosis: programmed cell death in health and disease. Biosci Rep, 14(2), 67-81.

Brown, A. M. (2004). Brain glycogen re-awakened. J Neurochem, 89(3), 537-552. doi:10.1111/j.1471-4159.2004.02421.x

Brown, A. M., Tekkok, S. B., \& Ransom, B. R. (2003). Glycogen regulation and functional role in mouse white matter. $J$ Physiol, 549(Pt 2), 501-512. doi:10.1113/jphysiol.2003.042416

Burri, P. H., \& Weibel, E. R. (1971). Morphometric estimation of pulmonary diffusion capacity. II. Effect of $\mathrm{Po} 2$ on the growing lung, adaption of the growing rat lung to hypoxia and hyperoxia. Respir Physiol, 11(2), 247-264. 
Burte, F., Carelli, V., Chinnery, P. F., \& Yu-Wai-Man, P. (2015). Disturbed mitochondrial dynamics and neurodegenerative disorders. Nat Rev Neurol, 11(1), 11-24. doi:10.1038/nrneurol.2014.228

Bustin, S. A., Benes, V., Garson, J. A., Hellemans, J., Huggett, J., Kubista, M., . . Wittwer, C. T. (2009). The MIQE guidelines: minimum information for publication of quantitative real-time PCR experiments. Clin Chem, 55(4), 611-622. doi:10.1373/clinchem.2008.112797

Calbet, J. A., Lundby, C., \& Boushel, R. (2016). Integrative Conductance of Oxygen During Exercise at Altitude. Adv Exp Med Biol, 903, 395-408. doi:10.1007/978-1-48997678-9_26

Cater, D. B., Garattini, S., Marina, F., \& Silver, I. A. (1961). Changes of Oxygen Tension in Brain and Somatic Tissues Induced by Vasodilator and Vasoconstrictor Drugs. Proceedings of the Royal Society of London. Series B, Biological Sciences, 155(958), 136158.

Chelikani, P., Fita, I., \& Loewen, P. C. (2004). Diversity of structures and properties among catalases. Cell Mol Life Sci, 61(2), 192-208. doi:10.1007/s00018-003-3206-5

Cherubini, M., \& Gines, S. (2017). Mitochondrial fragmentation in neuronal degeneration: Toward an understanding of HD striatal susceptibility. Biochem Biophys Res Commun, 483(4), 1063-1068. doi:10.1016/j.bbrc.2016.08.042

Chouchani, E. T., Pell, V. R., Gaude, E., Aksentijevic, D., Sundier, S. Y., Robb, E. L., . . Murphy, M. P. (2014). Ischaemic accumulation of succinate controls reperfusion injury through mitochondrial ROS. Nature, 515(7527), 431-435. doi:10.1038/nature13909

Cipolat, S., Martins de Brito, O., Dal Zilio, B., \& Scorrano, L. (2004). OPA1 requires mitofusin 1 to promote mitochondrial fusion. Proc Natl Acad Sci U S A, 101(45), 1592715932. doi:10.1073/pnas.0407043101

Clarke, D., \& Sokoloff, L. (1999). Circulation and Energy Metabolism of the Brain (Vol. Chapter 31). Philadelphia: Lippincott-Raven. 
Cogliati, S., Calvo, E., Loureiro, M., Guaras, A. M., Nieto-Arellano, R., Garcia-Poyatos, C., . . Enriquez, J. A. (2016). Mechanism of super-assembly of respiratory complexes III and IV. Nature, 539(7630), 579-582. doi:10.1038/nature20157

Cogliati, S., Enriquez, J. A., \& Scorrano, L. (2016). Mitochondrial Cristae: Where Beauty Meets Functionality. Trends Biochem Sci, 41(3), 261-273. doi:10.1016/j.tibs.2016.01.001

Cogliati, S., Frezza, C., Soriano, M. E., Varanita, T., Quintana-Cabrera, R., Corrado, M., ... Scorrano, L. (2013). Mitochondrial cristae shape determines respiratory chain supercomplexes assembly and respiratory efficiency. Cell, 155(1), 160-171. doi:10.1016/j.cell.2013.08.032

Commoner, J. T., Pake. (1954). Free radicals in biological materials. Nature, 174, 686-691.

Cuende, J., Moreno, S., Bolanos, J. P., \& Almeida, A. (2008). Retinoic acid downregulates Rael leading to APC(Cdh1) activation and neuroblastoma SH-SY5Y differentiation. Oncogene, 27(23), 3339-3344. doi:10.1038/sj.onc.1210987

Cummins, T. R., Agulian, S. K., \& Haddad, G. G. (1993). Oxygen tension clamp around single neurons in vitro: a computerized method for studies on $\mathrm{O} 2$ deprivation. $J$ Neurosci Methods, 46(3), 183-189.

Curtis, D. R., Phillis, J. W., \& Watkins, J. C. (1960). The chemical excitation of spinal neurones by certain acidic amino acids. $J$ Physiol, 150, 656-682.

Czarny, P., Wigner, P., Galecki, P., \& Sliwinski, T. (2017). The interplay between inflammation, oxidative stress, DNA damage, DNA repair and mitochondrial dysfunction in depression. Prog Neuropsychopharmacol Biol Psychiatry. doi:10.1016/j.pnpbp.2017.06.036

D'Autreaux, B., \& Toledano, M. B. (2007). ROS as signalling molecules: mechanisms that generate specificity in ROS homeostasis. Nat Rev Mol Cell Biol, 8(10), 813-824. doi:10.1038/nrm2256

Dalmonte, M. E., Forte, E., Genova, M. L., Giuffre, A., Sarti, P., \& Lenaz, G. (2009). Control of respiration by cytochrome c oxidase in intact cells: role of the membrane potential. J Biol Chem, 284(47), 32331-32335. doi:10.1074/jbc.M109.050146 
Davies, K. M., Blum, T. B., \& Kühlbrandt, W. (2018). Conserved in situ arrangement of complex I and III $<$ sub $>2</$ sub $>$ in mitochondrial respiratory chain supercomplexes of mammals, yeast, and plants. Proceedings of the National Academy of Sciences. doi:10.1073/pnas.1720702115

Davis, C. H., Kim, K. Y., Bushong, E. A., Mills, E. A., Boassa, D., Shih, T., . . MarshArmstrong, N. (2014). Transcellular degradation of axonal mitochondria. Proc Natl Acad Sci US A, 111(26), 9633-9638. doi:10.1073/pnas.1404651111

Delgado-Esteban, M., Garcia-Higuera, I., Maestre, C., Moreno, S., \& Almeida, A. (2013). APC/C-Cdh1 coordinates neurogenesis and cortical size during development. Nat Commun, 4, 2879. doi:10.1038/ncomms3879

Denko, N. C. (2008). Hypoxia, HIF1 and glucose metabolism in the solid tumour. Nat Rev Cancer, 8(9), 705-713. doi:10.1038/nrc2468

Deponte, M. (2013). Glutathione catalysis and the reaction mechanisms of glutathionedependent enzymes. Biochim Biophys Acta, 1830(5), 3217-3266. doi:10.1016/j.bbagen.2012.09.018

Devor, A., Sakadzic, S., Saisan, P. A., Yaseen, M. A., Roussakis, E., Srinivasan, V. J., . . Boas, D. A. (2011). "Overshoot" of $\mathrm{O}(2)$ is required to maintain baseline tissue oxygenation at locations distal to blood vessels. $J$ Neurosci, 31(38), 13676-13681. doi:10.1523/jneurosci.1968-11.2011

Dharmaraja, A. T. (2017). Role of Reactive Oxygen Species (ROS) in Therapeutics and Drug Resistance in Cancer and Bacteria. J Med Chem, 60(8), 3221-3240. doi:10.1021/acs.jmedchem.6b01243

Diaz, F., Barrientos, A., \& Fontanesi, F. (2009). Evaluation of the mitochondrial respiratory chain and oxidative phosphorylation system using blue native gel electrophoresis. Curr Protoc Hum Genet, Chapter 19, Unit19.14. doi:10.1002/0471142905.hg1904s63

DiMauro, S., Tanji, K., \& Schon, E. A. (2012). The many clinical faces of cytochrome c oxidase deficiency. Adv Exp Med Biol, 748, 341-357. doi:10.1007/978-1-4614-3573-0_14 
Dringen, R., Brandmann, M., Hohnholt, M. C., \& Blumrich, E. M. (2015). GlutathioneDependent Detoxification Processes in Astrocytes. Neurochem Res, 40(12), 2570-2582. doi:10.1007/s11064-014-1481-1

Dringen, R., Pfeiffer, B., \& Hamprecht, B. (1999). Synthesis of the antioxidant glutathione in neurons: supply by astrocytes of CysGly as precursor for neuronal glutathione. $J$ Neurosci, 19(2), 562-569.

Du, C., Fang, M., Li, Y., Li, L., \& Wang, X. (2000). Smac, a mitochondrial protein that promotes cytochrome c-dependent caspase activation by eliminating IAP inhibition. Cell, $102(1), 33-42$

Duan, C. (2016). Hypoxia-inducible factor 3 biology: complexities and emerging themes. Am J Physiol Cell Physiol, 310(4), C260-269. doi:10.1152/ajpcell.00315.2015

Dudkina, N. V., Kudryashev, M., Stahlberg, H., \& Boekema, E. J. (2011). Interaction of complexes I, III, and IV within the bovine respirasome by single particle cryoelectron tomography. Proc Natl Acad Sci U S A, 108(37), 15196-15200. doi:10.1073/pnas.1107819108

Emerling, B. M., Weinberg, F., Snyder, C., Burgess, Z., Mutlu, G. M., Viollet, B., . . . Chandel, N. S. (2009). Hypoxic activation of AMPK is dependent on mitochondrial ROS but independent of an increase in AMP/ATP ratio. Free Radic Biol Med, 46(10), 13861391. doi:10.1016/j.freeradbiomed.2009.02.019

Fridovich, I. (1997). Superoxide anion radical (O2-.), superoxide dismutases, and related matters. J Biol Chem, 272(30), 18515-18517.

Friedland, R. P., \& Iadecola, C. (1991). Roy and Sherrington (1890): a centennial reexamination of "On the regulation of the blood-supply of the brain". Neurology, 41(1), $10-14$.

Galloway, C. A., Lee, H., Nejjar, S., Jhun, B. S., Yu, T., Hsu, W., \& Yoon, Y. (2012). Transgenic control of mitochondrial fission induces mitochondrial uncoupling and relieves diabetic oxidative stress. Diabetes, 61(8), 2093-2104. doi:10.2337/db11-1640 
Garcia-Nogales, P., Almeida, A., \& Bolanos, J. P. (2003). Peroxynitrite protects neurons against nitric oxide-mediated apoptosis. A key role for glucose-6-phosphate dehydrogenase activity in neuroprotection. J Biol Chem, 278(2), 864-874. doi:10.1074/jbc.M206835200

Gerschman, R., Gilbert, D. L., Nye, S. W., Dwyer, P., \& Fenn, W. O. (1954). Oxygen poisoning and x-irradiation-A mechanism in common. Science, 119, 623-626.

Gielis, J. F., Beckers, P. A. J., Briedé, J. J., Cos, P., \& Van Schil, P. E. (2017). Oxidative and nitrosative stress during pulmonary ischemia-reperfusion injury: from the lab to the OR. Annals of Translational Medicine, 5(6), 131. doi:10.21037/atm.2017.03.32

Gomes, L. C., Di Benedetto, G., \& Scorrano, L. (2011). During autophagy mitochondria elongate, are spared from degradation and sustain cell viability. Nat Cell Biol, 13(5), 589598. doi:10.1038/ncb2220

Gomez-Lazaro, M., Bonekamp, N. A., Galindo, M. F., Jordan, J., \& Schrader, M. (2008). 6-Hydroxydopamine (6-OHDA) induces Drp1-dependent mitochondrial fragmentation in SH-SY5Y cells. Free Radic Biol Med, 44(11), 1960-1969. doi:10.1016/j.freeradbiomed.2008.03.009

Gordon, G. R., Choi, H. B., Rungta, R. L., Ellis-Davies, G. C., \& MacVicar, B. A. (2008). Brain metabolism dictates the polarity of astrocyte control over arterioles. Nature, 456(7223), 745-749. doi:10.1038/nature07525

Gowthami, N., Sunitha, B., Kumar, M., Prasad, T. S. K., Gayathri, N., Padmanabhan, B., \& Bharath, M. M. S. (2018). Mapping the protein phosphorylation sites in human mitochondrial complex I (NADH: ubiquinone oxidoreductase): A bioinformatics study with implications for brain aging and neurodegeneration. $J$ Chem Neuroanat. doi:10.1016/j.jchemneu.2018.02.004

Gu, Y. Z., Moran, S. M., Hogenesch, J. B., Wartman, L., \& Bradfield, C. A. (1998). Molecular characterization and chromosomal localization of a third alpha-class hypoxia inducible factor subunit, HIF3alpha. Gene Expr, 7(3), 205-213.

Gulbins, E., Dreschers, S., \& Bock, J. (2003). Role of mitochondria in apoptosis. Exp Physiol, 88(1), 85-90. 
Gutmann, I., \& Wahlefeld, A. W. (1974). In H. U. Bergmeyer (Ed.), Methods of Enzymatic Analysis (Weinheim ed.).

Hall, A., Nelson, K., Poole, L. B., \& Karplus, P. A. (2011). Structure-based insights into the catalytic power and conformational dexterity of peroxiredoxins. Antioxid Redox Signal, 15(3), 795-815. doi:10.1089/ars.2010.3624

Halliwell, B. (1994). Free radicals, antioxidants, and human disease: curiosity, cause, or consequence? Lancet, 344(8924), 721-724.

Han, D., Antunes, F., Canali, R., Rettori, D., \& Cadenas, E. (2003). Voltage-dependent anion channels control the release of the superoxide anion from mitochondria to cytosol. $J$ Biol Chem, 278(8), 5557-5563. doi:10.1074/jbc.M210269200

Hara, S., Hamada, J., Kobayashi, C., Kondo, Y., \& Imura, N. (2001). Expression and characterization of hypoxia-inducible factor (HIF)-3alpha in human kidney: suppression of HIF-mediated gene expression by HIF-3alpha. Biochem Biophys Res Commun, 287(4), 808-813. doi:10.1006/bbrc.2001.5659

Hayakawa, K., Esposito, E., Wang, X., Terasaki, Y., Liu, Y., Xing, C., . . Lo, E. H. (2016). Transfer of mitochondria from astrocytes to neurons after stroke. Nature, 535(7613), 551555. doi:10.1038/nature 18928

Herrero-Mendez, A., Almeida, A., Fernandez, E., Maestre, C., Moncada, S., \& Bolanos, J. P. (2009). The bioenergetic and antioxidant status of neurons is controlled by continuous degradation of a key glycolytic enzyme by APC/C-Cdh1. Nat Cell Biol, 11(6), 747-752. doi:10.1038/ncb1881

Hohenhaus, E., Paul, A., McCullough, R. E., Kucherer, H., \& Bartsch, P. (1995). Ventilatory and pulmonary vascular response to hypoxia and susceptibility to high altitude pulmonary oedema. Eur Respir J, 8(11), 1825-1833.

Horvat, S., Beyer, C., \& Arnold, S. (2006). Effect of hypoxia on the transcription pattern of subunit isoforms and the kinetics of cytochrome c oxidase in cortical astrocytes and cerebellar neurons. J Neurochem, 99(3), 937-951. doi:10.1111/j.1471-4159.2006.04134.x 
Howell, K., Preston, R. J., \& McLoughlin, P. (2003). Chronic hypoxia causes angiogenesis in addition to remodelling in the adult rat pulmonary circulation. $J$ Physiol, 547(Pt 1), 133145. doi:10.1113/jphysiol.2002.030676

Hwang, A. B., Ryu, E. A., Artan, M., Chang, H. W., Kabir, M. H., Nam, H. J., . . Lee, S. J. (2014). Feedback regulation via AMPK and HIF-1 mediates ROS-dependent longevity in Caenorhabditis elegans. Proc Natl Acad Sci U $S$ A, 111(42), E4458-4467. doi:10.1073/pnas.1411199111

Hypoxia: Translation in Progress. (2016). (Robert C. Roach, Peter H. Hacket, \& P. D. Wagner Eds.): Springer US.

Iadecola, C. (2004). Neurovascular regulation in the normal brain and in Alzheimer's disease. Nat Rev Neurosci, 5(5), 347-360. doi:10.1038/nrn1387

Imam, M. U., Zhang, S., Ma, J., Wang, H., \& Wang, F. (2017). Antioxidants Mediate Both Iron Homeostasis and Oxidative Stress. Nutrients, 9(7). doi:10.3390/nu9070671

Iommarini, L., Porcelli, A. M., Gasparre, G., \& Kurelac, I. (2017). Non-Canonical Mechanisms Regulating Hypoxia-Inducible Factor 1 Alpha in Cancer. Front Oncol, 7, 286. doi: $10.3389 /$ fonc. 2017.00286

Jaakkola, P., Mole, D. R., Tian, Y. M., Wilson, M. I., Gielbert, J., Gaskell, S. J., . . . Ratcliffe, P. J. (2001). Targeting of HIF-alpha to the von Hippel-Lindau ubiquitylation complex by O2-regulated prolyl hydroxylation. Science, 292(5516), 468-472. doi:10.1126/science. 1059796

Jahani-Asl, A., Cheung, E. C., Neuspiel, M., MacLaurin, J. G., Fortin, A., Park, D. S., . . Slack, R. S. (2007). Mitofusin 2 protects cerebellar granule neurons against injury-induced cell death. J Biol Chem, 282(33), 23788-23798. doi:10.1074/jbc.M703812200

James, W. (1890). The Principles of Psychology. New York: McGraw-Hill.

Jastroch, M., Divakaruni, A. S., Mookerjee, S., Treberg, J. R., \& Brand, M. D. (2010). Mitochondrial proton and electron leaks. Essays in biochemistry, 47, 53-67. doi: $10.1042 /$ bse 0470053 
Jimenez-Blasco, D., Santofimia-Castano, P., Gonzalez, A., Almeida, A., \& Bolanos, J. P. (2015). Astrocyte NMDA receptors' activity sustains neuronal survival through a Cdk5Nrf2 pathway. Cell Death Differ. doi:10.1038/cdd.2015.49

Kadenbach, B. (2017). Regulation of Mammalian 13-Subunit Cytochrome c Oxidase and Binding of other Proteins: Role of NDUFA4. Trends Endocrinol Metab, 28(11), 761-770. doi:10.1016/j.tem.2017.09.003

Kaluz, S., Kaluzova, M., \& Stanbridge, E. J. (2008). Regulation of gene expression by hypoxia: integration of the HIF-transduced hypoxic signal at the hypoxia-responsive element. Clin Chim Acta, 395(1-2), 6-13. doi:10.1016/j.cca.2008.05.002

Kanzaki, H., Wada, S., Narimiya, T., Yamaguchi, Y., Katsumata, Y., Itohiya, K., . . . Nakamura, Y. (2017). Pathways that Regulate ROS Scavenging Enzymes, and Their Role in Defense Against Tissue Destruction in Periodontitis. Front Physiol, 8, 351. doi:10.3389/fphys.2017.00351

Keith, B., Johnson, R. S., \& Simon, M. C. (2011). HIF1alpha and HIF2alpha: sibling rivalry in hypoxic tumour growth and progression. Nat Rev Cancer, 12(1), 9-22. doi: $10.1038 / \mathrm{nrc} 3183$

Kerr, J. F., Wyllie, A. H., \& Currie, A. R. (1972). Apoptosis: a basic biological phenomenon with wide-ranging implications in tissue kinetics. Br J Cancer, 26(4), 239257.

Khacho, M., \& Slack, R. S. (2017). Mitochondrial dynamics in the regulation of neurogenesis: From development to the adult brain. Dev Dyn. doi:10.1002/dvdy.24538

Khazaei, M., \& Aghaz, F. (2017). Reactive Oxygen Species Generation and Use of Antioxidants during In Vitro Maturation of Oocytes. Int J Fertil Steril, 11(2), 63-70. doi:10.22074/ijfs.2017.4995

Kim, E., Wright, M. J., Sioson, L., Novos, T., Gill, A. J., Benn, D. E., . . Clifton-Bligh, R. J. (2017). Utility of the succinate: Fumarate ratio for assessing SDH dysfunction in different tumor types. Mol Genet Metab Rep, 10, 45-49. doi:10.1016/j.ymgmr.2016.12.006

Kim, H., Scimia, M. C., Wilkinson, D., Trelles, R. D., Wood, M. R., Bowtell, D., .. Ronai, Z. A. (2011). Fine-tuning of Drp1/Fis1 availability by AKAP121/Siah2 regulates 
mitochondrial adaptation to hypoxia. Mol Cell, 44(4), 532-544. doi:10.1016/j.molcel.2011.08.045

Kisliakov, I., Samoilov, M. O., Ivanov, K. P., \& Luchakov Iu, I. (1983). [Dynamics of oxygen transport from the capillaries to the cortical neurons]. Fiziol Zh SSSR Im I M Sechenova, 69(1), 63-69.

Kisliakov Iu, I., \& Ivanov, K. P. (1976). [Distribution of carbon dioxide and oxygen tension in neurons of the cerebral cortex and their surrounding tissue]. Fiziol Zh SSSR Im I M Sechenova, 62(1), 66-72.

Kussmaul, L., \& Hirst, J. (2006). The mechanism of superoxide production by NADH:ubiquinone oxidoreductase (complex I) from bovine heart mitochondria. Proc Natl Acad Sci U S A, 103(20), 7607-7612. doi:10.1073/pnas.0510977103

LaManna, J. C. (2007). Hypoxia in the central nervous system. Essays Biochem, 43, 139151. doi:10.1042/bse0430139

Lambert, A. J., \& Brand, M. D. (2004). Superoxide production by NADH:ubiquinone oxidoreductase (complex I) depends on the $\mathrm{pH}$ gradient across the mitochondrial inner membrane. Biochem J, 382(Pt 2), 511-517. doi:10.1042/bj20040485

Lapuente-Brun, E., Moreno-Loshuertos, R., Acin-Perez, R., Latorre-Pellicer, A., Colas, C., Balsa, E., . . . Enriquez, J. A. (2013). Supercomplex assembly determines electron flux in the mitochondrial electron transport chain. Science, 340(6140), 1567-1570. doi:10.1126/science. 1230381

Lee, S. J., Hwang, A. B., \& Kenyon, C. (2010). Inhibition of respiration extends C. elegans life span via reactive oxygen species that increase HIF-1 activity. Curr Biol, 20(23), 21312136. doi:10.1016/j.cub.2010.10.057

Lemire, J., Alhasawi, A., Appanna, V. P., Tharmalingam, S., \& Appanna, V. D. (2017). Metabolic defense against oxidative stress: The road less travelled-so far. J Appl Microbiol. doi:10.1111/jam.13509

Lenaz, G., \& Genova, M. L. (2012). Supramolecular organisation of the mitochondrial respiratory chain: a new challenge for the mechanism and control of oxidative phosphorylation. Adv Exp Med Biol, 748, 107-144. doi:10.1007/978-1-4614-3573-0_5 
Lenaz, G., Tioli, G., Falasca, A. I., \& Genova, M. L. (2016). Complex I function in mitochondrial supercomplexes. Biochim Biophys Acta, 1857(7), 991-1000. doi:10.1016/j.bbabio.2016.01.013

Letts, J. A., Fiedorczuk, K., \& Sazanov, L. A. (2016). The architecture of respiratory supercomplexes. Nature, 537(7622), 644-648. doi:10.1038/nature19774

Letts, J. A., \& Sazanov, L. A. (2015). Gaining mass: the structure of respiratory complex I-from bacterial towards mitochondrial versions. Curr Opin Struct Biol, 33, 135-145. doi:10.1016/j.sbi.2015.08.008

Li, L. Y., Luo, X., \& Wang, X. (2001). Endonuclease G is an apoptotic DNase when released from mitochondria. Nature, 412(6842), 95-99. doi:10.1038/35083620

Li, P., Zhou, L., Zhao, T., Liu, X., Zhang, P., Liu, Y., . . Li, Q. (2017). Caspase-9: structure, mechanisms and clinical application. Oncotarget, 8(14), 23996-24008. doi:10.18632/oncotarget.15098

Liberto, C. M., Albrecht, P. J., Herx, L. M., Yong, V. W., \& Levison, S. W. (2004). Proregenerative properties of cytokine-activated astrocytes. Journal of Neurochemistry, 89(5), 1092-1100. doi:10.1111/j.1471-4159.2004.02420.x

Liu, K. J., Bacic, G., Hoopes, P. J., Jiang, J., Du, H., Ou, L. C., . . Swartz, H. M. (1995). Assessment of cerebral pO2 by EPR oximetry in rodents: effects of anesthesia, ischemia, and breathing gas. Brain Res, 685(1-2), 91-98.

Liu, X., \& Hajnoczky, G. (2011). Altered fusion dynamics underlie unique morphological changes in mitochondria during hypoxia-reoxygenation stress. Cell Death Differ, 18(10), 1561-1572. doi:10.1038/cdd.2011.13

Liu, X., Kim, C. N., Yang, J., Jemmerson, R., \& Wang, X. (1996). Induction of apoptotic program in cell-free extracts: requirement for dATP and cytochrome c. Cell, 86(1), 147157.

Lobo-Jarne, T., \& Ugalde, C. (2017). Respiratory chain supercomplexes: Structures, function and biogenesis. Semin Cell Dev Biol. doi:10.1016/j.semcdb.2017.07.021 
Lopez-Fabuel, I., Le Douce, J., Logan, A., James, A. M., Bonvento, G., Murphy, M. P., . . Bolanos, J. P. (2016). Complex I assembly into supercomplexes determines differential mitochondrial ROS production in neurons and astrocytes. Proc Natl Acad Sci US A, 113(46), 13063-13068. doi:10.1073/pnas.1613701113

Lopez-Mejia, I. C., \& Fajas, L. (2015). Cell cycle regulation of mitochondrial function. Curr Opin Cell Biol, 33, 19-25. doi:10.1016/j.ceb.2014.10.006

Magistretti, P. J., Morrison, J. H., Shoemaker, W. J., Sapin, V., \& Bloom, F. E. (1981). Vasoactive intestinal polypeptide induces glycogenolysis in mouse cortical slices: a possible regulatory mechanism for the local control of energy metabolism. Proc Natl Acad Sci U S A, 78(10), 6535-6539.

Maher, F., Davies-Hill, T. M., \& Simpson, I. A. (1996). Substrate specificity and kinetic parameters of GLUT3 in rat cerebellar granule neurons. Biochem J, 315 ( Pt 3), 827-831.

Maksymetz, J., Moran, S. P., \& Conn, P. J. (2017). Targeting metabotropic glutamate receptors for novel treatments of schizophrenia. Mol Brain, 10(1), 15. doi:10.1186/s13041017-0293-z

Maranzana, E., Barbero, G., Falasca, A. I., Lenaz, G., \& Genova, M. L. (2013). Mitochondrial respiratory supercomplex association limits production of reactive oxygen species from complex I. Antioxid Redox Signal, 19(13), 1469-1480. doi:10.1089/ars.2012.4845

Marrocco, I., Altieri, F., \& Peluso, I. (2017). Measurement and Clinical Significance of Biomarkers of Oxidative Stress in Humans. Oxid Med Cell Longev, 2017, 6501046. doi: $10.1155 / 2017 / 6501046$

Masoud, G. N., \& Li, W. (2015). HIF-1alpha pathway: role, regulation and intervention for cancer therapy. Acta Pharm Sin B, 5(5), 378-389. doi:10.1016/j.apsb.2015.05.007

Mata-Greenwood, E., Goyal, D., \& Goyal, R. (2017). Comparative and Experimental Studies on the Genes Altered by Chronic Hypoxia in Human Brain Microendothelial Cells. Front Physiol, 8, 365. doi:10.3389/fphys.2017.00365 
McCaslin, A. F. H., Chen, B. R., Radosevich, A. J., Cauli, B., \& Hillman, E. M. C. (2011). In vivo 3D morphology of astrocyte-vasculature interactions in the somatosensory cortex: implications for neurovascular coupling. Journal of Cerebral Blood Flow \& Metabolism, 31(3), 795-806. doi:10.1038/jcbfm.2010.204

Milenkovic, D., Blaza, J. N., Larsson, N. G., \& Hirst, J. (2017). The Enigma of the Respiratory Chain Supercomplex. Cell Metab, 25(4), 765-776. doi:10.1016/j.cmet.2017.03.009

Mishra, A. (2017). Binaural blood flow control by astrocytes: listening to synapses and the vasculature. J Physiol, 595(6), 1885-1902. doi:10.1113/jp270979

Miyazono, Y., Hirashima, S., Ishihara, N., Kusukawa, J., Nakamura, K. I., \& Ohta, K. (2018). Uncoupled mitochondria quickly shorten along their long axis to form indented spheroids, instead of rings, in a fission-independent manner. Sci Rep, 8(1), 350. doi:10.1038/s41598-017-18582-6

Morais, V. A., Haddad, D., Craessaerts, K., De Bock, P. J., Swerts, J., Vilain, S., . . De Strooper, B. (2014). PINK1 loss-of-function mutations affect mitochondrial complex I activity via NdufA10 ubiquinone uncoupling. Science, 344(6180), 203-207. doi:10.1126/science. 1249161

Mosso, A. (1880). On the circulation of blood in the human brain. Rend Accad Lincei 5,, 5, 122.

Mueckler, M., \& Thorens, B. (2013). The SLC2 (GLUT) family of membrane transporters. Mol Aspects Med, 34(2-3), 121-138. doi:10.1016/j.mam.2012.07.001

Muller, F. L., Liu, Y., \& Van Remmen, H. (2004). Complex III releases superoxide to both sides of the inner mitochondrial membrane. J Biol Chem, 279(47), 49064-49073. doi:10.1074/jbc.M407715200

Mulligan, S. J., \& MacVicar, B. A. (2004). Calcium transients in astrocyte endfeet cause $\begin{array}{llrr}\text { cerebrovascular } \quad \text { constrictions. } & \text { Nature, } & \text { 431(7005), } & \text { 195-199. }\end{array}$ doi:http://www.nature.com/nature/journal/v431/n7005/suppinfo/nature02827_S1.html 
Murphy-Royal, C., Dupuis, J., Groc, L., \& Oliet, S. H. (2017). Astroglial glutamate transporters in the brain: Regulating neurotransmitter homeostasis and synaptic transmission. J Neurosci Res. doi:10.1002/jnr.24029

Murphy, M. P. (2009). How mitochondria produce reactive oxygen species. Biochem J, 417(1), 1-13. doi:10.1042/bj20081386

Murphy, M. P., Krueger, M. J., Sablin, S. O., Ramsay, R. R., \& Singer, T. P. (1995). Inhibition of complex I by hydrophobic analogues of N-methyl-4-phenylpyridinium $(\mathrm{MPP}+)$ and the use of an ion-selective electrode to measure their accumulation by mitochondria and electron-transport particles. Biochem J, 306 ( Pt 2), 359-365.

Muster, B., Kohl, W., Wittig, I., Strecker, V., Joos, F., Haase, W., . . Busch, K. (2010). Respiratory chain complexes in dynamic mitochondria display a patchy distribution in life cells. PLoS One, 5(7), e11910. doi:10.1371/journal.pone.0011910

Nagoor Meeran, M. F., Javed, H., Al Taee, H., Azimullah, S., \& Ojha, S. K. (2017). Pharmacological Properties and Molecular Mechanisms of Thymol: Prospects for Its Therapeutic Potential and Pharmaceutical Development. Front Pharmacol, 8, 380. doi:10.3389/fphar.2017.00380

Nair, P., Whalen, W. J., \& Buerk, D. (1975). PO2 of cat cerebral cortex: response to breathing N2 and 100 per cent O21. Microvasc Res, 9(2), 158-165.

Nedergaard, M., Ransom, B., \& Goldman, S. A. (2003). New roles for astrocytes: redefining the functional architecture of the brain. Trends Neurosci, 26(10), 523-530. doi:10.1016/j.tins.2003.08.008

Nehlig, A. (1999). Age-dependent pathways of brain energy metabolism: the suckling rat, a natural model of the ketogenic diet. Epilepsy Res, 37(3), 211-221.

Nehlig, A. (2004). Brain uptake and metabolism of ketone bodies in animal models. Prostaglandins Leukot Essent Fatty Acids, 70(3), 265-275. doi:10.1016/j.plefa.2003.07.006

Newman, E. A. (2013). Functional hyperemia and mechanisms of neurovascular coupling in the retinal vasculature. $J$ Cereb Blood Flow Metab, 33(11), 1685-1695. doi:10.1038/jcbfm.2013.145 
Oe, Y., Baba, O., Ashida, H., Nakamura, K. C., \& Hirase, H. (2016). Glycogen distribution in the microwave-fixed mouse brain reveals heterogeneous astrocytic patterns. Glia, 64(9), 1532-1545. doi:10.1002/glia.23020

Papa, S., Sardanelli, A. M., Scacco, S., Petruzzella, V., Technikova-Dobrova, Z., Vergari, R., \& Signorile, A. (2002). The NADH: ubiquinone oxidoreductase (complex I) of the mammalian respiratory chain and the cAMP cascade. J Bioenerg Biomembr, 34(1), 1-10.

Papouin, T., Dunphy, J., Tolman, M., Foley, J. C., \& Haydon, P. G. (2017). Astrocytic control of synaptic function. Philos Trans $R$ Soc Lond B Biol Sci, 372(1715). doi:10.1098/rstb.2016.0154

Parpura, V., Basarsky, T. A., Liu, F., Jeftinija, K., Jeftinija, S., \& Haydon, P. G. (1994). Glutamate-mediated astrocyte-neuron signalling. Nature, 369(6483), 744-747. doi:10.1038/369744a0

Pawlus, M. R., \& Hu, C. J. (2013). Enhanceosomes as integrators of hypoxia inducible factor (HIF) and other transcription factors in the hypoxic transcriptional response. Cell Signal, 25(9), 1895-1903. doi:10.1016/j.cellsig.2013.05.018

Peacock, A. J. (1998). ABC of oxygen: oxygen at high altitude. Bmj, 317(7165), 10631066.

Pellerin, L. (2010). Food for thought: the importance of glucose and other energy substrates for sustaining brain function under varying levels of activity. Diabetes Metab, 36 Suppl 3, S59-63. doi:10.1016/s1262-3636(10)70469-9

Pellerin, L., \& Magistretti, P. J. (1994). Glutamate uptake into astrocytes stimulates aerobic glycolysis: a mechanism coupling neuronal activity to glucose utilization. Proc Natl Acad Sci U S A, 91(22), 10625-10629.

Pellerin, L., Pellegri, G., Bittar, P. G., Charnay, Y., Bouras, C., Martin, J. L., . . Magistretti, P. J. (1998). Evidence supporting the existence of an activity-dependent astrocyte-neuron lactate shuttle. Dev Neurosci, 20(4-5), 291-299. doi:10.1159/000017324 
Perea, G., Navarrete, M., \& Araque, A. (2009). Tripartite synapses: astrocytes process and control synaptic information. Trends Neurosci, 32(8), 421-431. doi:10.1016/j.tins.2009.05.001

Perez-Alvarez, A., \& Araque, A. (2013). Astrocyte-neuron interaction at tripartite synapses. Curr Drug Targets, 14(11), 1220-1224.

Petruzzella, V., \& Papa, S. (2002). Mutations in human nuclear genes encoding for subunits of mitochondrial respiratory complex I: the NDUFS4 gene. Gene, 286(1), 149-154.

Poulin, M. J. (1998). Aspects of cerebral blood flow in humans.

Prabhakar, N. R., \& Semenza, G. L. (2012). Adaptive and maladaptive cardiorespiratory responses to continuous and intermittent hypoxia mediated by hypoxia-inducible factors 1 and 2. Physiol Rev, 92(3), 967-1003. doi:10.1152/physrev.00030.2011

Rak, M., Benit, P., Chretien, D., Bouchereau, J., Schiff, M., El-Khoury, R., . . Rustin, P. (2016). Mitochondrial cytochrome c oxidase deficiency. Clin Sci (Lond), 130(6), 393-407. doi:10.1042/cs20150707

Rehni, A. K., \& Dave, K. R. (2018). Impact of Hypoglycemia on Brain Metabolism During Diabetes. Mol Neurobiol. doi:10.1007/s12035-018-1044-6

Rey, S., Schito, L., Wouters, B. G., Eliasof, S., \& Kerbel, R. S. (2017). Targeting HypoxiaInducible Factors for Antiangiogenic Cancer Therapy. Trends Cancer, 3(7), 529-541. doi:10.1016/j.trecan.2017.05.002

Rich, P. R. (2017). Mitochondrial cytochrome c oxidase: catalysis, coupling and controversies. Biochem Soc Trans, 45(3), 813-829. doi:10.1042/bst20160139

Rippa, M., Spanio, L., \& Pontremoli, S. (1966). [6-phosphogluconate dehydrogenase: inhibition of the enzymatic activity by pyridoxal phosphate]. Boll Soc Ital Biol Sper, 42(12), 748-750.

Rodriguez-Rodriguez, P., Fernandez, E., Almeida, A., \& Bolanos, J. P. (2012). Excitotoxic stimulus stabilizes PFKFB3 causing pentose-phosphate pathway to glycolysis switch and neurodegeneration. Cell Death Differ, 19(10), 1582-1589. doi:10.1038/cdd.2012.33 
Saez, I., Duran, J., Sinadinos, C., Beltran, A., Yanes, O., Tevy, M. F., . . Guinovart, J. J. (2014). Neurons have an active glycogen metabolism that contributes to tolerance to hypoxia. J Cereb Blood Flow Metab, 34(6), 945-955. doi:10.1038/jcbfm.2014.33

Salceda, S., \& Caro, J. (1997). Hypoxia-inducible factor 1alpha (HIF-1alpha) protein is rapidly degraded by the ubiquitin-proteasome system under normoxic conditions. Its stabilization by hypoxia depends on redox-induced changes. J Biol Chem, 272(36), 2264222647.

Salvesen, G. S., \& Dixit, V. M. (1997). Caspases: intracellular signaling by proteolysis. Cell, 91(4), 443-446.

Sandrone, S., Bacigaluppi, M., Galloni, M. R., Cappa, S. F., Moro, A., Catani, M., . . Martino, G. (2014). Weighing brain activity with the balance: Angelo Mosso's original manuscripts come to light. Brain, 137(Pt 2), 621-633. doi:10.1093/brain/awt091

Santel, A., \& Fuller, M. T. (2001). Control of mitochondrial morphology by a human mitofusin. J Cell Sci, 114(Pt 5), 867-874.

Schagger, H., \& Pfeiffer, K. (2000). Supercomplexes in the respiratory chains of yeast and mammalian mitochondria. Embo j, 19(8), 1777-1783. doi:10.1093/emboj/19.8.1777

Schagger, H., \& von Jagow, G. (1991). Blue native electrophoresis for isolation of membrane protein complexes in enzymatically active form. Anal Biochem, 199(2), 223231.

Scialo, F., Fernandez-Ayala, D. J., \& Sanz, A. (2017). Role of Mitochondrial Reverse Electron Transport in ROS Signaling: Potential Roles in Health and Disease. Front Physiol, 8, 428. doi:10.3389/fphys.2017.00428

Semenza, G. L. (2004). Hydroxylation of HIF-1: oxygen sensing at the molecular level. Physiology (Bethesda), 19, 176-182. doi:10.1152/physiol.00001.2004

Seylaz, J., \& Pinard, E. (1978). Continuous measurement of gas partial pressures in intracerebral tissue. J Appl Physiol Respir Environ Exerc Physiol, 44(4), 528-533. 
Shapiro, H. M., Natale, P. J., \& Kamentsky, L. A. (1979). Estimation of membrane potentials of individual lymphocytes by flow cytometry. Proc Natl Acad Sci U S A, 76(11), 5728-5730.

Sharma, L. K., Lu, J., \& Bai, Y. (2009). Mitochondrial respiratory complex I: structure, function and implication in human diseases. Curr Med Chem, 16(10), 1266-1277.

Sheldon, A. L., \& Robinson, M. B. (2007). The role of glutamate transporters in neurodegenerative diseases and potential opportunities for intervention. Neurochem Int, 51(6-7), 333-355. doi:10.1016/j.neuint.2007.03.012

Shen, Y. H., Wang, X. L., \& Wilcken, D. E. (1998). Nitric oxide induces and inhibits apoptosis through different pathways. FEBS Lett, 433(1-2), 125-131.

Sick, T. J., Lutz, P. L., LaManna, J. C., \& Rosenthal, M. (1982). Comparative brain oxygenation and mitochondrial redox activity in turtles and rats. $J$ Appl Physiol Respir Environ Exerc Physiol, 53(6), 1354-1359.

Siebenmann, C., \& Lundby, C. (2015). Regulation of cardiac output in hypoxia. Scand J Med Sci Sports, 25 Suppl 4, 53-59. doi:10.1111/sms.12619

Signorini, L., Granata, S., Lupo, A., \& Zaza, G. (2017). Naturally Occurring Compounds: New Potential Weapons against Oxidative Stress in Chronic Kidney Disease. Int J Mol Sci, 18(7). doi:10.3390/ijms18071481

Simard, M., \& Nedergaard, M. (2004). The neurobiology of glia in the context of water and ion homeostasis. Neuroscience, 129(4), 877-896. doi:https://doi.org/10.1016/j.neuroscience.2004.09.053

Smirnova, E., Griparic, L., Shurland, D. L., \& van der Bliek, A. M. (2001). Dynaminrelated protein Drp1 is required for mitochondrial division in mammalian cells. Mol Biol Cell, 12(8), 2245-2256.

Smith, R. H., Guilbeau, E. J., \& Reneau, D. D. (1977). The oxygen tension field within a discrete volume of cerebral cortex. Microvasc Res, 13(2), 233-240. 
Sokoloff, L. (1960). The metabolism of the central nervous system in vivo In Handbook of Physiology (American Physiological Society ed., pp. 1843-1864). Washington DC.

Spanio, L., Rippa, M., \& Pontremoli, S. (1966). [6-phosphogluconate dehydrogenase: stabilization of the bond between the enzyme and pyridoxal phosphate]. Boll Soc Ital Biol Sper, 42(12), 750-752.

Staerck, C., Gastebois, A., Vandeputte, P., Calenda, A., Larcher, G., Gillmann, L., . . . Fleury, M. J. J. (2017). Microbial antioxidant defense enzymes. Microbial Pathogenesis, 110, 56-65. doi:https://doi.org/10.1016/j.micpath.2017.06.015

Sullivan, L. B., \& Chandel, N. S. (2014). Mitochondrial reactive oxygen species and cancer. Cancer Metab, 2, 17. doi:10.1186/2049-3002-2-17

Susin, S. A., Lorenzo, H. K., Zamzami, N., Marzo, I., Brenner, C., Larochette, N., . . . Kroemer, G. (1999). Mitochondrial release of caspase-2 and -9 during the apoptotic process. J Exp Med, 189(2), 381-394.

Suzuki, Y., Imai, Y., Nakayama, H., Takahashi, K., Takio, K., \& Takahashi, R. (2001). A serine protease, HtrA2, is released from the mitochondria and interacts with XIAP, inducing cell death. Mol Cell, 8(3), 613-621.

Suzuki, Y., Ono, Y., \& Hirabayashi, Y. (1998). Rapid and specific reactive oxygen species generation via NADPH oxidase activation during Fas-mediated apoptosis. FEBS Lett, 425(2), 209-212.

Tatar, S. Y., Obek, E., \& Cikcikoglu Yildirim, N. (2017). Antioxidant Response in Duckweed After Exposure to Secondary Effluent from Municipal Wastewater Treatment Plant, Elazı̆g, Turkey. Bulletin of Environmental Contamination and Toxicology. doi:10.1007/s00128-017-2133-3

Taylor, C. T., \& Moncada, S. (2010). Nitric oxide, cytochrome C oxidase, and the cellular response to hypoxia. Arterioscler Thromb Vasc Biol, 30(4), 643-647. doi:10.1161/atvbaha.108.181628

Thomas, J. L., Pham, H., Li, Y., Hall, E., Perkins, G. A., Ali, S. S., . . Singh, P. (2017). Hypoxia inducible factor-1alpha activation improves renal oxygenation and mitochondrial 
function in early chronic kidney disease. Am $J$ Physiol Renal Physiol, ajprenal.00579.02016. doi:10.1152/ajprenal.00579.2016

Toledano, B. J., Bastien, Y., Noya, F., Baruchel, S., \& Mazer, B. (1997). Platelet-activating factor abrogates apoptosis induced by cross-linking of the surface IgM receptor in a human B lymphoblastoid cell line. J Immunol, 158(8), 3705-3715.

Trumpower, B. L. (1990). The protonmotive Q cycle. Energy transduction by coupling of proton translocation to electron transfer by the cytochrome bc1 complex. J Biol Chem, 265(20), 11409-11412.

Tsatmali, M., Walcott, E. C., Makarenkova, H., \& Crossin, K. L. (2006). Reactive oxygen species modulate the differentiation of neurons in clonal cortical cultures. Mol Cell Neurosci, 33(4), 345-357. doi:10.1016/j.mcn.2006.08.005

Turrens, J. F. (2003). Mitochondrial formation of reactive oxygen species. J Physiol, 552(Pt 2), 335-344. doi:10.1113/jphysiol.2003.049478

Tzeng, Y. C., \& Ainslie, P. N. (2014). Blood pressure regulation IX: cerebral autoregulation under blood pressure challenges. Eur J Appl Physiol, 114(3), 545-559. doi:10.1007/s00421-013-2667-y

Ugarte-Uribe, B., \& Garcia-Saez, A. J. (2017). Apoptotic foci at mitochondria: in and around Bax pores. Philos Trans $R$ Soc Lond B Biol Sci, 372(1726). doi:10.1098/rstb.2016.0217

van Hall, G., Stromstad, M., Rasmussen, P., Jans, O., Zaar, M., Gam, C., . . Nielsen, H. B. (2009). Blood lactate is an important energy source for the human brain. J Cereb Blood Flow Metab, 29(6), 1121-1129. doi:10.1038/jcbfm.2009.35

van Loo, G., Schotte, P., van Gurp, M., Demol, H., Hoorelbeke, B., Gevaert, K., . . . Vandenabeele, P. (2001). Endonuclease G: a mitochondrial protein released in apoptosis and involved in caspase-independent DNA degradation. Cell Death Differ, 8(12), 11361142. doi: $10.1038 /$ sj.cdd. 4400944

Varanita, T., Soriano, M. E., Romanello, V., Zaglia, T., Quintana-Cabrera, R., Semenzato, M., . . . Scorrano, L. (2015). The OPA1-dependent mitochondrial cristae remodeling 
pathway controls atrophic, apoptotic, and ischemic tissue damage. Cell Metab, 21(6), 834844. doi:10.1016/j.cmet.2015.05.007

Vartak, R., Porras, C. A., \& Bai, Y. (2013). Respiratory supercomplexes: structure, function and assembly. Protein Cell, 4(8), 582-590. doi:10.1007/s13238-013-3032-y

Verhagen, A. M., Ekert, P. G., Pakusch, M., Silke, J., Connolly, L. M., Reid, G. E., . . Vaux, D. L. (2000). Identification of DIABLO, a mammalian protein that promotes apoptosis by binding to and antagonizing IAP proteins. Cell, 102(1), 43-53.

Vermes, I., \& Haanen, C. (1994). Apoptosis and programmed cell death in health and disease. Adv Clin Chem, 31, 177-246.

Vermes, I., Haanen, C., \& Reutelingsperger, C. (2000). Flow cytometry of apoptotic cell death. J Immunol Methods, 243(1-2), 167-190.

Wamelink, M. M., Struys, E. A., \& Jakobs, C. (2008). The biochemistry, metabolism and inherited defects of the pentose phosphate pathway: a review. J Inherit Metab Dis, 31(6), 703-717. doi:10.1007/s10545-008-1015-6

Weibel, E. R. (2017). Lung morphometry: the link between structure and function. Cell Tissue Res, 367(3), 413-426. doi:10.1007/s00441-016-2541-4

Wiesinger, H., Hamprecht, B., \& Dringen, R. (1997). Metabolic pathways for glucose in astrocytes. Glia, 21(1), 22-34.

Wigerup, C., Påhlman, S., \& Bexell, D. (2016). Therapeutic targeting of hypoxia and hypoxia-inducible factors in cancer. Pharmacology \& Therapeutics, 164, 152-169. doi:https://doi.org/10.1016/j.pharmthera.2016.04.009

Wilson, D. F., Pastuszko, A., DiGiacomo, J. E., Pawlowski, M., Schneiderman, R., \& Delivoria-Papadopoulos, M. (1991). Effect of hyperventilation on oxygenation of the brain cortex of newborn piglets. J Appl Physiol (1985), 70(6), 2691-2696.

Wilson, D. F., Roy, A., \& Lahiri, S. (2005). Immediate and long-term responses of the carotid body to high altitude. High Alt Med Biol, 6(2), 97-111. doi:10.1089/ham.2005.6.97 
Wirth, C., Brandt, U., Hunte, C., \& Zickermann, V. (2016). Structure and function of mitochondrial complex I. Biochim Biophys Acta, 1857(7), 902-914. doi:10.1016/j.bbabio.2016.02.013

Wright, E. M. (2013). Glucose transport families SLC5 and SLC50. Mol Aspects Med, 34(2-3), 183-196. doi:10.1016/j.mam.2012.11.002

Xu, K., Boas, D. A., Sakadzic, S., \& LaManna, J. C. (2017). Brain Tissue PO2 Measurement During Normoxia and Hypoxia Using Two-Photon Phosphorescence Lifetime Microscopy. Adv Exp Med Biol, 977, 149-153. doi:10.1007/978-3-319-55231$6 \_20$

Yamada, K. (2016). Vascular potassium channels in NVC. Prog Brain Res, 225, 63-73. doi:10.1016/bs.pbr.2016.01.001

Yang, S. L., Wu, C., Xiong, Z. F., \& Fang, X. (2015). Progress on hypoxia-inducible factor3: Its structure, gene regulation and biological function (Review). Mol Med Rep, 12(2), 2411-2416. doi:10.3892/mmr.2015.3689

Yarjanli, Z., Ghaedi, K., Esmaeili, A., Rahgozar, S., \& Zarrabi, A. (2017). Iron oxide nanoparticles may damage to the neural tissue through iron accumulation, oxidative stress, and protein aggregation. BMC Neurosci, 18(1), 51. doi:10.1186/s12868-017-0369-9

Zamzami, N., Susin, S. A., Marchetti, P., Hirsch, T., Gomez-Monterrey, I., Castedo, M., \& Kroemer, G. (1996). Mitochondrial control of nuclear apoptosis. J Exp Med, 183(4), 15331544.

Zielke, H. R., Zielke, C. L., \& Baab, P. J. (2009). Direct measurement of oxidative metabolism in the living brain by microdialysis: a review. J Neurochem, 109 Suppl 1, 2429. doi:10.1111/j.1471-4159.2009.05941.x

Zundorf, G., Kahlert, S., Bunik, V. I., \& Reiser, G. (2009). alpha-Ketoglutarate dehydrogenase contributes to production of reactive oxygen species in glutamatestimulated hippocampal neurons in situ. Neuroscience, 158(2), 610-616. doi:10.1016/j.neuroscience.2008.10.015 